\title{
A RESIDENTIAL MICRO TRI-GENERATION SYSTEM BASED ON A GAS FIRED STIRLING ENGINE CHP AND THERMO-CHEMICAL ACCUMULATOR (TCA)
}

\author{
By
}

Zannatul Moiet Hasib

B.Sc. (Mechanical Engineering)

Bangladesh University of Engineering and Technology (BUET), Bangladesh, 2011

\author{
A Thesis \\ Presented to Ryerson University \\ In Partial Fulfillment of the \\ Requirements for the degree of \\ MASTER OF APPLIED SCIENCE \\ In the program of \\ Mechanical Engineering
}

Toronto, Ontario, Canada, 2013

(c) Zannatul Moiet Hasib, 2013 


\section{Author's Declaration}

I hereby declare that I am the sole author of this thesis.

I authorize Ryerson University to lend this thesis to other institutions or purpose of scholarly research.

Zannatul Moiet Hasib

I further authorize Ryerson University to reproduce this thesis by photocopying or by other means, in total or in part, at the request of other institutions or individuals for the purpose of scholarly research. 


\title{
A RESIDENTIAL MICRO TRI-GENERATION SYSTEM BASED ON A GAS FIRED STIRLING ENGINE CHP AND THERMO-CHEMICAL ACCUMULATOR (TCA)
}

\author{
Zannatul Moiet Hasib \\ Master of Applied Science \\ Program of Mechanical Engineering \\ Ryerson University, Toronto, Ontario, Canada, 2013
}

\begin{abstract}
Cooling production has application in a considerable number of fields in human life, such as: food processing, air-conditioning, pharmaceuticals, etc. The conventional refrigeration system driven by the vapour compression cycle in general inhibits sustainable development due to it's association with high electricity consumption as well as global warming. Tri-generation can address this problem as it produces electricity, heating and cooling from a single fuel source, and it also uses an environmentally friendly working fluid. This thesis describes in detail the development of a residential tri-generation system based on ClimateWell ${ }^{\circledR}$ technology and a gas fired co-generation unit. Detailed design of a tri-generation system and a multi-tank cascade storage system has been developed. Based on the design, a residential tri-generation system has been installed and commissioned at the House-B of the TRCA, located in Vaughan, Ontario. The installed tri-generation system is instrumented with over 30 different sensors and the experimental data collected were analyzed to evaluate the performance of the system. It has been found that the multi-tank system is capable of preheating the incoming water main cold water by $6-7^{\circ} \mathrm{C}$ by utilizing the rejected heat of the tri-generation system. Experimental data show that the co-generation system has a thermal efficiency of $71 \%$ and the COP of the ClimateWell ${ }^{\circledR}$ system is 0.365 . A TRNSYS model of the tri-generation system and the multi-tank storage system has also been developed and the models were validated with the experimental data. The models were also used to simulate the performance of the integrated system for different input conditions.
\end{abstract}




\section{Acknowledgements}

This thesis would not have been come to light without the cooperation of the author's supervisors Dr. Seth Dworkin, Dr. Alan Fung and Dr. David Naylor. The author expresses his deepest appreciation to his supervisors. The author is very grateful to Union Gas Limited, Renteknik Group, Natural Science and Engineering Research Council (NSERC) of Canada, MITACS, ClimateWell $^{\circledR}$ and the Toronto and Region Conservation Authority (TRCA) for their support in this project. The author also express special thanks to Mr. John Overall, Mr. Lars Sjoberg, Mr. Darren Cooper, Mr. David Nixon, Mr. Dahai Zhang, Mr. Navid Ekrami and Mr. Pushan Lele for their guidance and support in the completion of this thesis. Special appreciation also goes to the Ryerson Center for Urban Energy (CUE) and its academic director, Dr. Bala Venkatesh, for the coordination of the project. 
The work is dedicated to my parents and my family members,

Who have helped me by their inspiration and blessings. 


\section{Table of Contents}

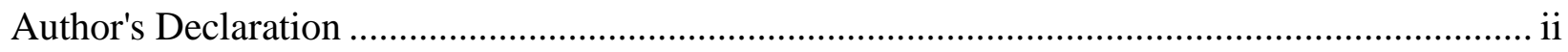

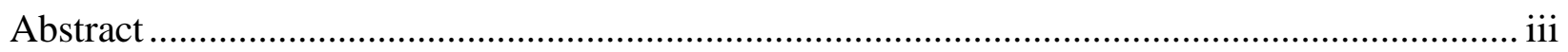

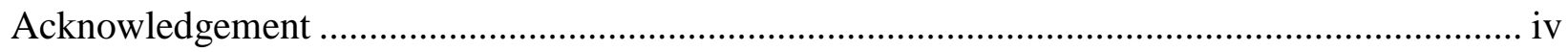

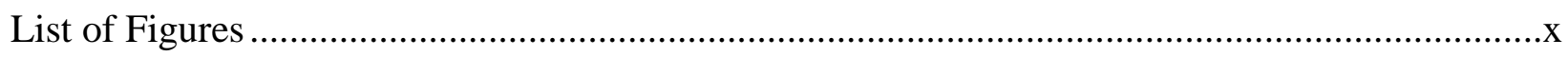

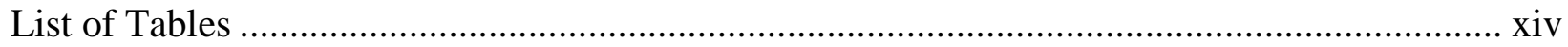

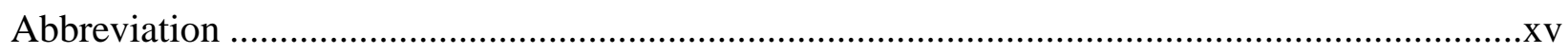

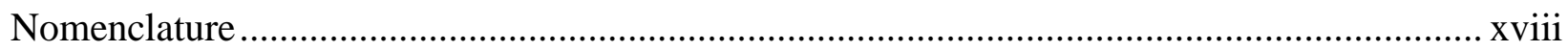

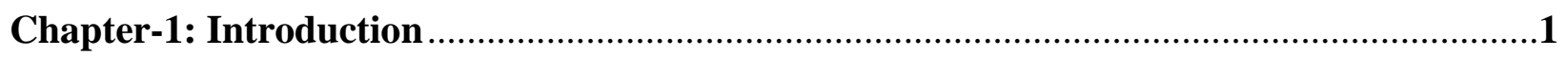

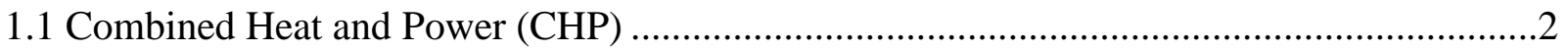

1.2 Tri-generation/Combined Heating, Cooling and Power (CHCP) .....................................

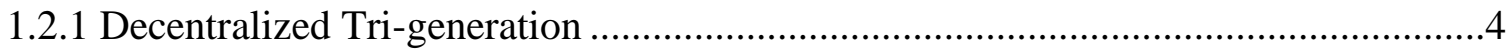

1.2.2 Centralized CHPs with Decentralized Cooling .................................................5

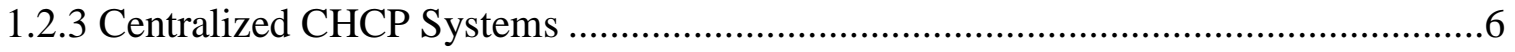

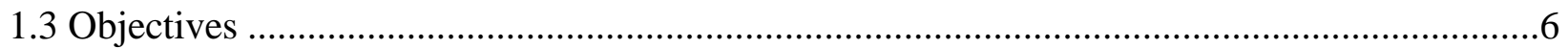

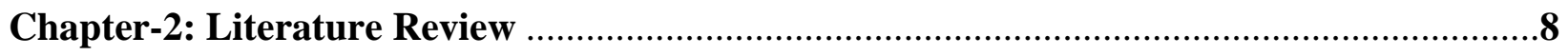

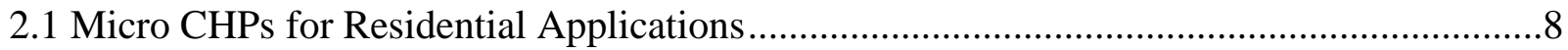

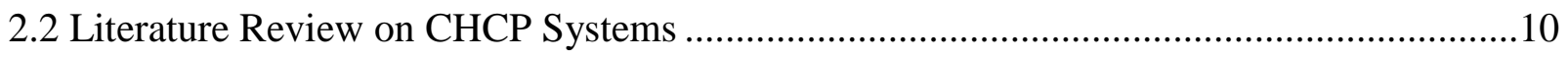

2.3 Literature Review on Multi-tank Systems ........................................................ 12

Chapter-3: Absorption, Adsorption and Thermo-chemical Accumulation (TCA) ..............16

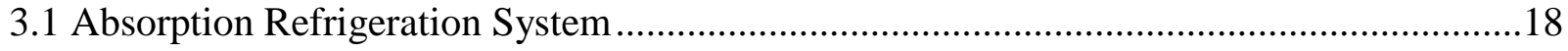

3.1.1 Working Principle of Absorption System ...................................................18

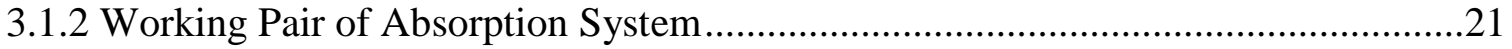


3.1.3 Evaluation of Absorption Refrigeration System for Residential Tri-generation ......21

3.2 Adsorption Refrigeration System .........................................................................22

3.2.1 Working Principle of Adsorption Refrigeration System .....................................23

3.2.2 Working Pair of Adsorption Refrigeration ....................................................25

3.2.3 Evaluation of Adsorption Refrigeration System for Residential Tri-generation .....26

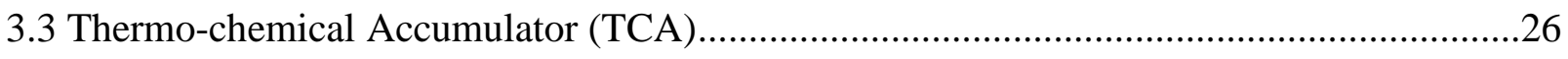

3.3.1 Details About ClimateWell ${ }^{\circ}$ Absorption Chiller.............................................27

3.3.2 Working Principle of TCA/ ClimateWell® Chiller …......................................28

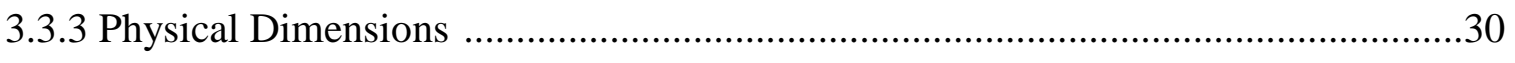

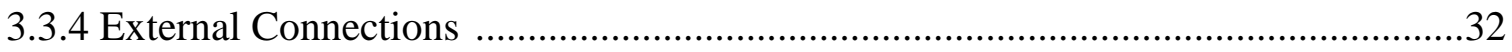

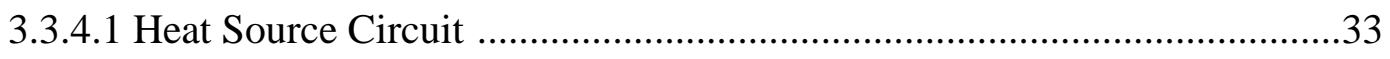

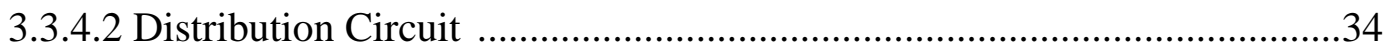

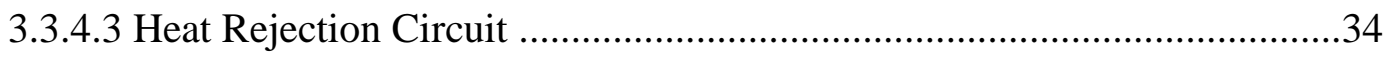

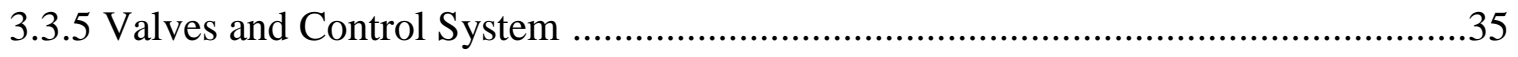

3.3.5.1 Valve Arrangement of ClimateWell® Chillers .....................................36

3.4 Safety Issues Related to ClimateWell ${ }^{\circledR}$ Chiller...............................................................40

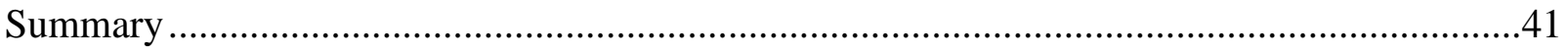

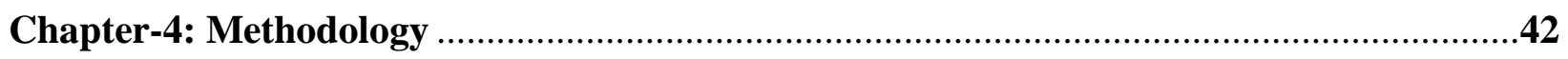

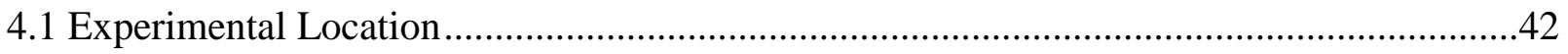

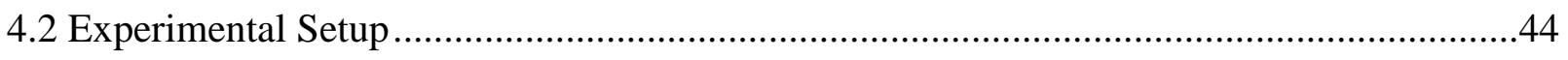

4.2.1 Piping and Instrumentation Diagram (P\&ID) ..............................................45

4.2.1.1 Heat Source Circuit ................................................................... 48

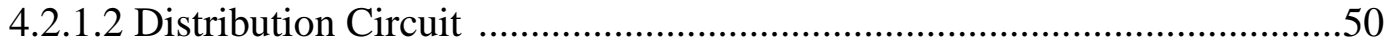


4.3 Commissioning if the Tri-generation System ...........................................................57

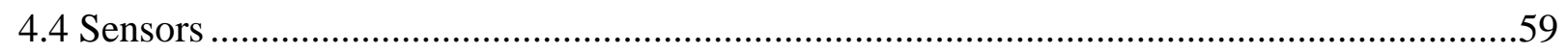

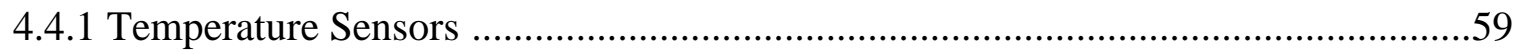

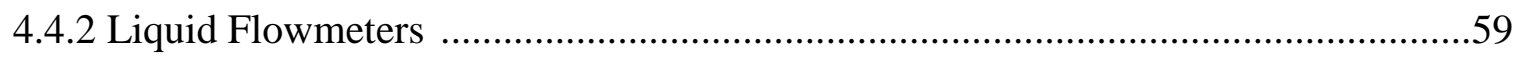

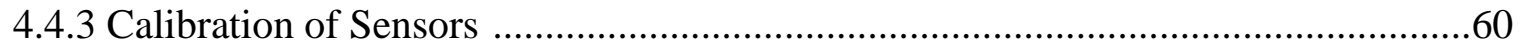

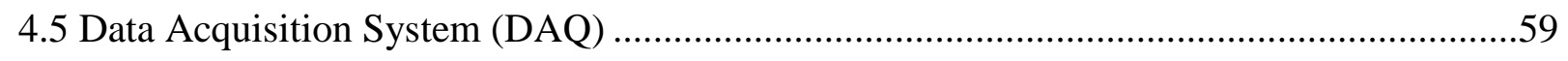

4.6 Energy Consumption, Generation and Efficiency Equations of the Tri-generation System 61

4.6.1 Propylene Glycol (PG) Solution .............................................................61

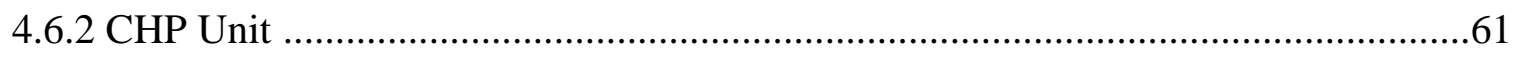

4.6.3 Cooling Capacity of ClimateWell ${ }^{\circledR}$ Chiller …................................................62

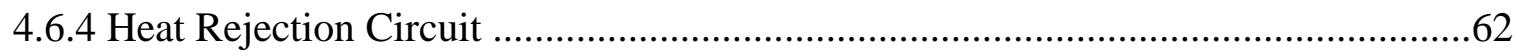

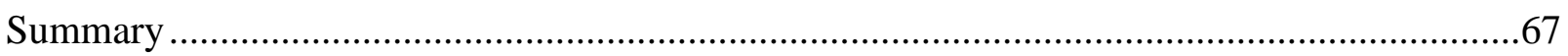

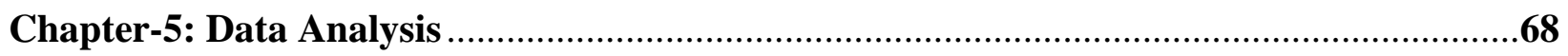

5.1 Charging Behaviour of the ClimateWell® Chiller ........................................................68

5.2 Discharge Behaviour of ClimateWell@ Chiller ........................................................ 77

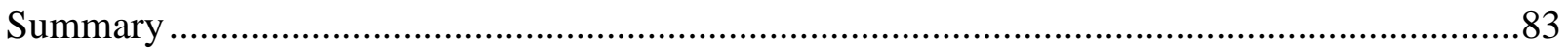

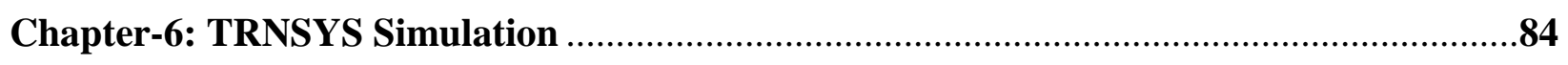

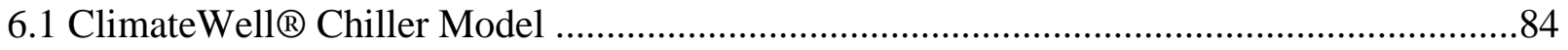

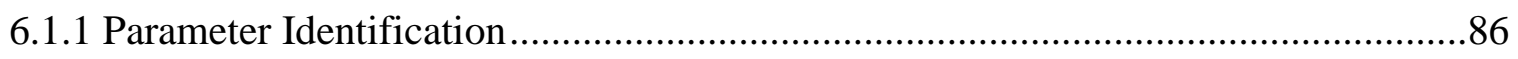

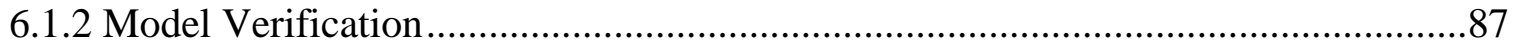

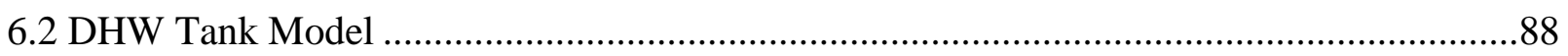

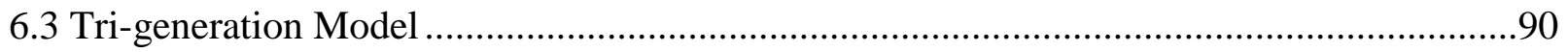


6.4 Simulation Results

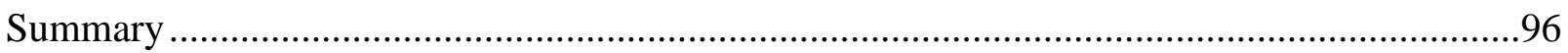

Chapter-7: Author's Contribution and Conclusion ...............................................................97

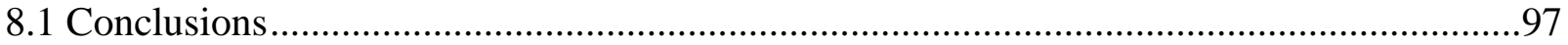

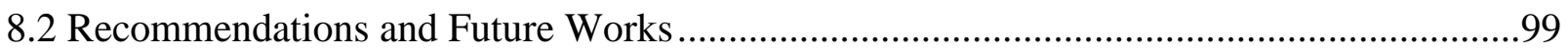

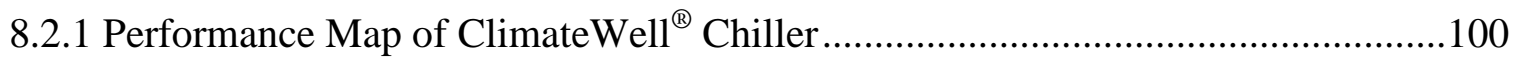

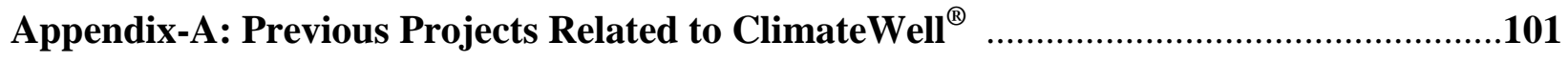

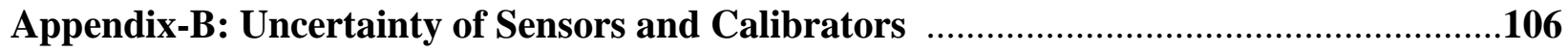

Appendix-C: Properties of Propylene Glycol ......................................................107

C.1 Density of Propylene Glycol Solution at Different Temperature .........................107

C.2 Specific Heat of Propylene Glycol Solution at Different Temperature ..................108

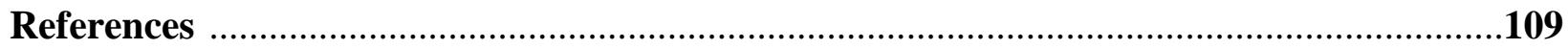




\section{List of Figures}

Figure 1.1 Technical Principles of co-generation ............................................................

Figure 1.2 Decentralized tri-generation systems ..........................................................4

Figure 1.3 Centralized CHP with decentralized cooling ........................................................5

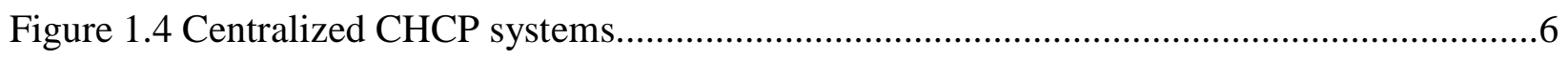

Figure 1.5 Block diagram of the integrated system ........................................................ 7

Figure 2.1 Divided indirect integral collector storage with two storage compartments ...............12

Figure 2.2 Schematic of an integrated collector system composed of a single perfectly stratified storage element and a counter flow heat-exchanger ............................................ 13

Figure 2.3 Multiple DHW tanks with immersed coil heat exchangers connected in series

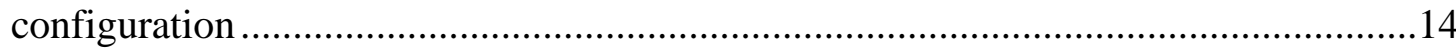

Figure 2.4 Schematic of two parallel connection configurations .........................................15

Figure 3.1 Classification of refrigeration systems …..................................................... 17

Figure 3.2 Working principle of a refrigeration cycle ....................................................19

Figure 3.3 Ideal absorption refrigeration cycle ............................................................ 19

Figure 3.4 Pressure-temperature diagram of ideal absorption cycle......................................20

Figure 3.5 Comparison between absorption and adsorption system.....................................22

Figure 3.6 Working principle of an adsorption refrigeration cycle ......................................24

Figure 3.7 Adsorption refrigeration system with two adsorber/desorber ................................25

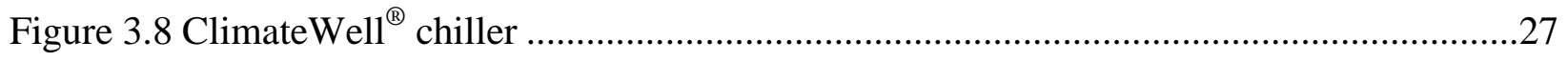

Figure 3.9 Schematic diagram of ClimateWell ${ }^{\circledR}$ barrels........................................................29

Figure 3.10 Physical dimension of the ClimateWell ${ }^{\circledR}$ unit ......................................................30

Figure 3.11 Connection diagram of the $\mathrm{ClimateWell}^{\circledR}$ chiller to external circuits .......................32

Figure 3.12 Charging performance of the ClimateWell chiller ..............................................33

Figure 3.13 Cooling performnace of the ClimateWell ${ }^{\circledR}$ chiller .................................................34 
Figure 3.14 ClimateWell ${ }^{\circledR}$ barrels connected to switching and controller unit ..... .36

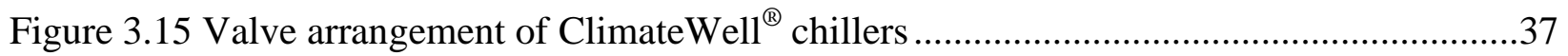

Figure 3.16 Schematic diagram of valve arrangement of ClimateWell ${ }^{\circledR}$ chillers .........................38

Figure 3.17 Valve schematic for Barrel-A charging and Barrel-B discharging ..........................39

Figure 3.18 Valve schematic for Barrel-B charging and Barrel-A discharging .........................40

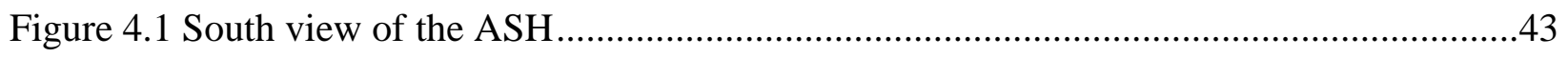

Figure 4.2 Simple diagram of the residential tri-generation system ....................................45

Figure 4.3 P\&ID of the residential tri-generation system ................................................47

Figure 4.4 (a) WHISPERGEN CHP (b) internal components of the CHP unit..........................49

Figure 4.5 P\&ID diagram of the heat source circuit .......................................................50

Figure 4.6 P\&ID diagram of the distribution circuit ..........................................................51

Figure 4.7 Theoretical energy conservation per barrel during charging cycle (b) Theoretical energy conservation per barrel during discharge cycle ...........................................52

Figure 4.8 (a) Multiple DHW tanks are connected in parallel (b) Multiple DHW tanks are

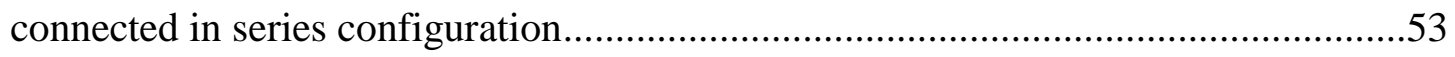

Figure 4.9 Cross section of the DHW tanks used for heat rejection ......................................54

Figure 4.10 Heat rejection circuit (before insulating) ......................................................57

Figure 4.11 (a) Series connection of two AHUs (b) AHU used in this project ..........................58

Figure 4.12 Energy conservation in DHW tanks ...........................................................63

Figure 5.1 (a) SOC vs. time for Barrel-B (b) SOC vs. time for Barrel-A .................................69

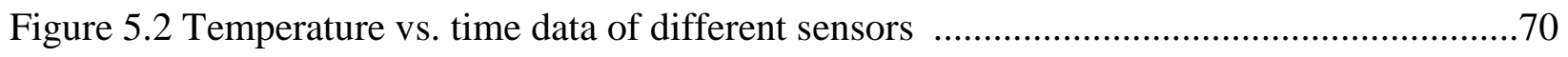

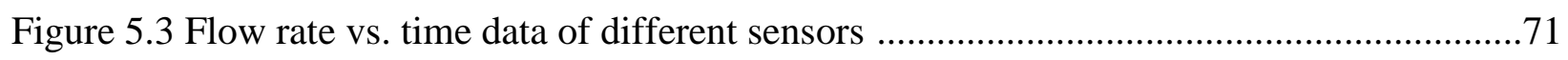

Figure 5.4 Heat transfer rate from CHP vs. time during charging cycle .................................72

Figure 5.5 Heat rejection rate and heat storage rate vs. time during charging cycle ..................72

Figure 5.6 Temperature of the working fluid at different points of the heat rejection circuit ......74

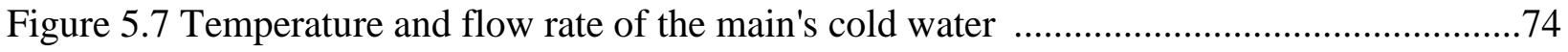


Figure 5.8 Temperature of water in three DHW tanks during the charging cycle .75

Figure 5.9 SOV vs. time for Barrel-A during discharge process .........................................77

Figure 5.10 Temperature and flow rate vs. time of the chilled water ........................................78

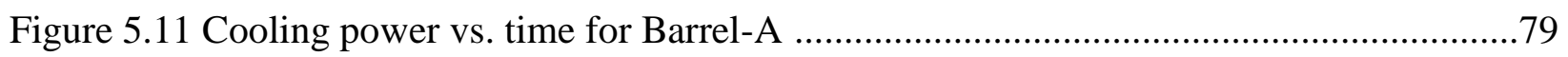

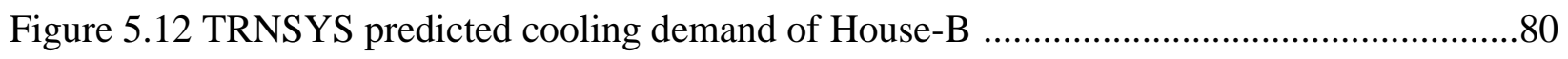

Figure 5.13 Temperature and heat rejection rate vs. time during discharge cycle .....................81

Figure 5.14 Flow rate vs. time in the heat rejection circuit ....................................................81

Figure 5.15 Energy flow diagram of the tri-generation system for each barrel of ClimateWell ${ }^{\circledR}$

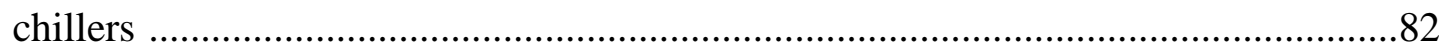

Figure 6.1 (a) Schematic if TYPE-215 single TCA/barrel (b) Complete ClimateWell ${ }^{\circledR}$ chiller comprising two barrels (TYPE-215) and a controller (TYPE-216)..........................85

Figure 6.2 Measured and simulated heat transfer rates for reactor and condenser for two full cycles of a single barrel

Figure 6.3 Comparison of experimental data and simulation results for heat rejection temperatures

Figure 6.4 Comparison of experimental data and simulation results for water temperature in the

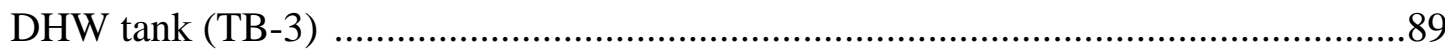

Figure 6.5 TRNSYS model overview if the residential tri-generation system .........................90

Figure 6.6 Simulation results for SOC vs. time ..........................................................91

Figure 6.7 Simulation results for temperature vs. time for charging ClimateWell ${ }^{\circledR}$ chiller .........92

Figure 6.8 Simulation results for the heat transfer rate vs. time ..........................................93

Figure 6.9 Simulation result for temperature vs. time at different point s of the tri-generation

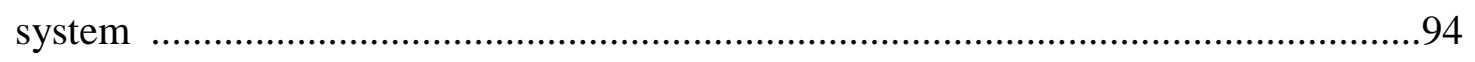

Figure 6.10 simulation results for temperature vs. time in the discharge circuit ......................95

Figure 6.11 Charging and discharge cycle of the climatewell ${ }^{\circledR}$ chiller ....................................96

Figure A.1 Functional block diagram of project-1 …................................................... 102

Figure A.2 Installation of the ClimateWell ${ }^{\circledR}$ version 7.0 chiller in project-1 ...........................102 
Figure A.3 Energy balance of the integrated system during summer

Figure A.4 Functional block diagram of project-2 ….....................................................104

Figure A.6 Installation of the ClimateWell ${ }^{\circledR} 10$ chiller in project-2 .........................................104 


\section{List of Tables}

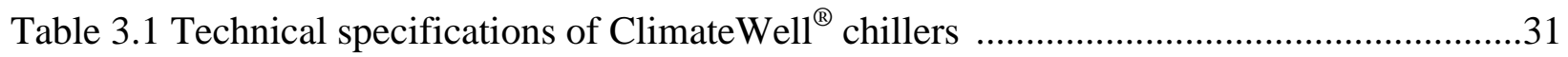

Table 3.2 Technical specifications of the three external circuits ..........................................32

Table 4.1 Comparison of HVAC systems among different housing standards .........................43

Table 4.2 Basic design feature of House-B .........................................................................44

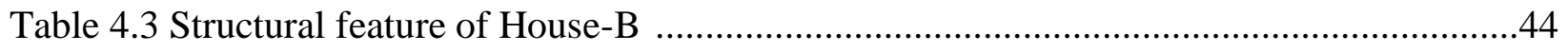

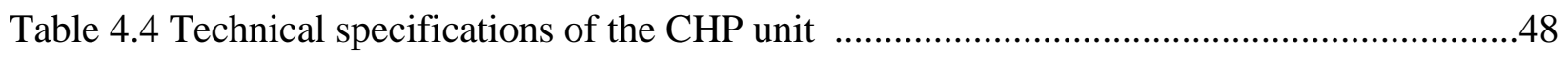

Table 4.5 Valve position for different combinations of heat rejection ...................................56

Table 4.6 List of sensor types and their input parameters .................................................59

Table 4.7 Heat rejection rate and the total heat rejection for different combinations .................66

Table 5.1 Energy conservation during the charging cycle ....................................................73

Table 5.2 Details energy conservation during the charging cycle ........................................76

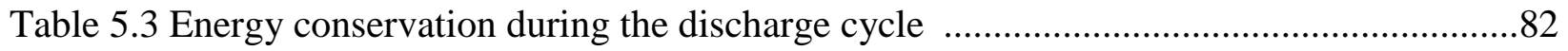

Table 6.1 Main parameters values identification for the ClimateWell ${ }^{\circledR}$ chiller .........................86

Table A.1 Performance data of the ClimateWell ${ }^{\circledR}$ system in project-2 ...................................105

Table B.1 Accuracy level of different sensors used .......................................................106

Table B.2 Accuracy level of different calibrators used .......................................................106 


\section{Abbreviations}

$\mathrm{AC}$

ACAC

$\mathrm{ACH}$

ACHS

AHU

ARHS

ARSP

ASME

ASHRAE

$\mathrm{BCAC}$

BILD

BCHS

BRHS

BRSP

BTU

$\mathrm{CCHT}$

CFC

CFM

$\mathrm{CHCP}$

CHP
Air Conditioning

Condenser AC valve of Barrel-A

Air Change Per Hour

Condenser Heat Sink Valve of Barrel-A

Air Handling Unit

Reactor Heat Sink Valve of Barrel-A

Reactor Solar Panel Valve of Barrel-A

American Society of Mechanical Engineers

American Society of Heating, Refrigeration and Air-

Conditioning Engineers

Condenser AC Valve of Barrel-B

Building Industry and Land Development Association

Condenser Heat Sink Valve of Barrel-B

Reactor Heat Sink Valve of Barrel-B

Reactor Solar Panel Valve of Barrel-B

British Thermal Unit

Canadian Center for Housing Technology

Chlorofluro Carbon

Cubic Feet Per Meter

Combined Heating, Cooling and Power

Combined Heat and Power 
CHS

CAC

COP

CSA

CW

DAQ

DHWT

DHW

DV

EU

GHG

GPM

GSHP

HCFC

HHV

HS

HVAC

HX

IC

IEA

$\mathrm{kWh}$

LEED

MCHP
Condenser Heat Sink (valve)

Condenser AC (valve)

Coefficient of Performance

Canadian Standard Association

ClimateWell $^{\circledR}$

Data Acquisition System

Domestic Hot Water Tank

Domestic Hot Water

Diverting Valve

European Union

Greenhouse Gas

Gallon per Minute

Ground Source Heat Pump

Hydrochlorofluro Carbon

Higher Heating Value (for natural gas $37.8 \mathrm{MJ} / \mathrm{m}^{3}$ )

Heat Sink

Heating, Ventilation and Air conditioning

Heat Exchanger

Internal Combustion

International Energy Agency

Kilowatt Hour

Leadership in Energy and Environmental Design

Micro Combined Heat and Power 


$\begin{array}{ll}\text { NI } & \text { National Instruments } \\ \text { NRCan } & \text { Natural Resources Canada } \\ \text { P\&ID } & \text { Piping and Instrumentation Diagram } \\ \text { PG } & \text { Propylene Glycol } \\ \text { Pa } & \text { Pascal (Pressure unit } \mathrm{N} / \mathrm{m}^{2} \text { ) } \\ \text { RHS } & \text { Reactor Heat Sink (valve) } \\ \text { RSP } & \text { Reactor Solar Panel (valve) } \\ \text { RTD } & \text { Resistance Temperature Detector } \\ \text { SOC } & \text { State of Charge } \\ \text { SOV } & \text { State of Valve } \\ \text { SQL } & \text { Structured Query Language } \\ \text { TCA } & \text { Thermo-chemical Accumulator } \\ \text { TB } & \text { Terabyte } \\ \text { TDC } & \text { Thermally Driven Chillers } \\ \text { TOU } & \text { Time-of-Use } \\ \text { TRCA } & \text { Toronto and Regional Conservation Authority } \\ \text { VH } & \text { Valve in the Heat Rejection Circuit/Loop } \\ \text { XT } & \text { Expansion Tank }\end{array}$




\section{Nomenclature}

$\begin{array}{ll}\mathrm{C}_{\mathrm{p}} & \text { Specific heat capacity of water }(\mathrm{J} / \mathrm{kg} . \mathrm{K}) \\ \mathrm{C}_{\mathrm{P}, \mathrm{wf}} & \text { Specific heat capacity of working fluid }(\mathrm{J} / \mathrm{kg} . \mathrm{K}) \\ \mathrm{F} & \text { Temperature }\left({ }^{\circ} \mathrm{F}\right) \\ \mathrm{FL} & \text { Flow rate }(1 / \mathrm{min}) \\ \mathrm{m} & \text { Mass flow rate }(\mathrm{kg} / \mathrm{min}) \\ \mathrm{Q} & \text { Thermal power }(\mathrm{kWh}) \\ \mathrm{Q}_{\text {Electrical }} & \text { Electrical power } \\ \mathrm{T} & \text { Temperature }\left({ }^{\circ} \mathrm{C}\right) \\ \text { Ths } & \text { Temperature of the heat sink } \\ \mathrm{T}_{\mathrm{a}} & \text { Ambient temperature } \\ \mathrm{UA} & \text { Overall heat transfer coefficient }\left(\mathrm{kW} /{ }^{\circ} \mathrm{C}\right) \\ \mathrm{x} & \text { Loading factor }\end{array}$

\section{Greek symbols}

$\begin{array}{ll}\rho & \text { Density }\left(\mathrm{kg} / \mathrm{m}^{3}\right) \\ \eta & \text { Efficiency }\end{array}$




\section{Chapter-1 \\ Introduction}

In temperate and arctic regions of North America, the residential sector consumes about $16 \%$ of the total energy consumption. Consequently, this level of energy consumption is associated with greenhouse gas (GHG) emission, which is about 15\% of all GHGs emitted in Canada (Tanha, 2011). Thus the growing concern about the environment and rapid depletion of natural resources have made us think about net-zero energy homes. According to Natural Resources Canada (NRCan), by 2030 all new homes will be built to net-zero energy standards (Dembo et al., 2010, Barua et al., 2010). The government also attaches a great importance to energy conservation by providing encouraging initiatives, rules and regulations.

The traditional commercial non-natural working fluids used for refrigeration such as chlorofluorocarbons (CFCs), hydro chlorofluorocarbons (HCFCs), and hydro fluorocarbons (HFCs) result in ozone layer depletion and/or global warming. According to the Montreal Protocol 1997, international agreements have been signed to reduce the emission of these refrigerants (Merlin, 2002). European Regulation 2037/2000 which was implemented in October 2000, deals with the control and phase out schedule of all these ozone depleting substances. It is indicated that by 2015, use of HFCs will be strongly discouraged (European Parliament of the Council, 2000).

Thermally driven chillers, which can be powered by low grade waste heat, have received attention in recent years due to global warming and the harmful effects of CFCs and HCFCs. Moreover, in order to move closer to the goal of net-zero energy homes, numerous technologies can be adopted. Co-generation and tri-generation in residential buildings are among them. Cogeneration, as the name implies, refers to the simultaneous production of electricity and heating. Tri-generation is one step ahead of co-generation which produces three commodities (electricity, heating and cooling) from a single fuel source. It can be achieved by incorporating a heat activated chiller that utilizes the waste heat from the co-generation.

Electricity generation using any thermodynamic cycle must be coupled with heat rejection. Rejected heat which otherwise would be wasted, can be utilized in space heating and hot water production. Producing electricity and heating together, referred to as co-generation, is gaining 
popularity in residential sectors as it uses the energy sources efficiently. In temperate and arctic regions of North America, co-generation is suitable during the heating season due to the high demand of space heating and domestic hot water production. However, during the cooling season, rejected heat from the co-generation unit cannot be utilized properly due to low demand of heating. As a result, economic feasibility of the overall co-generation system suffers during the cooling season (Ekrami et al., 2012).

Coupling the co-generation systems with a chiller can maximize the benefit of the overall system during the cooling season. Heat activated cooling systems such as absorption, adsorption and thermo-chemical accumulators (TCA) are popular choices. But each of these systems has its own advantages, disadvantages and challenges. $\mathrm{LiCl}-\mathrm{H}_{2} \mathrm{O}$ cooling/thermal storage technologies, such as those offered by ClimateWell ${ }^{\circledR}$, can provide better solutions for residential applications.

While Combined Heat and Power (CHP) technologies have been well established for more than 100 years, the development of tri-generation is quite new and is limited to large scale power generation. Tri-generation is a promising technology that is becoming economically feasible in recent times for residential applications (Deng et al., 2011). Many of the previous works have shown that tri-generation systems possess energy savings, enhance efficiency and have low emission characteristics (Nurenz, 2010). The goal of this project is to scale down the trigeneration technology and present the potential use of the absorption chiller for residential application.

\subsection{Combined Heat and Power (CHP)}

CHP refers to a system that produces electricity and heating simultaneously from a single source of energy. Conversion of fossil fuel (e.g., natural gas, biomass, etc.) by any thermodynamic cycle is associated with heat rejection. In CHP systems, the by-product (heat) of electricity generation is utilized in space heating and hot water production. Thus, it is also known as co-generation or combined generation of electricity and heating. Co-generation technologies have been popular for many years. Advantages of co-generation over separate production of electricity and heat can be listed as below (Nurenz, 2010):

- Co-generation is $15 \%$ more efficient than producing heat and electricity separately.

- Co-generation produces fewer pollutants than any kind of separate energy production. 
- Co-generation ensures higher energy security.

For residential houses, electricity demand is nearly $1 \mathrm{~kW}$ and the domestic hot water requirement is nearly 200 1/day (Ekrami et al., 2012). So, micro CHP units are well suited for detached and semi-detached residential houses. Moreover, during the day time when most of the occupants are away from home, electrical demand is less than $1 \mathrm{~kW}$ and a CHP unit send the excess electrical energy produced to the grid during that peak time.

The main component of a CHP unit is the prime mover. Efficiency of the overall CHP system depends on the efficiency of the prime mover used. IC engines, gas turbines and fuel cells can be used as a prime mover for CHP systems. Each prime mover has different advantages as well as disadvantages. Stirling engines have electrical efficiency as high as $40 \%$ and overall efficiency may reach as high as 90\% (Frangopoulos, 2002). Moreover as the Stirling engines are less noisy in operation, they are most suitable for residential CHP system (Nurenz, 2010). A comparison between co-generation and separate production of electricity and thermal energy is given in Figure 1.1.

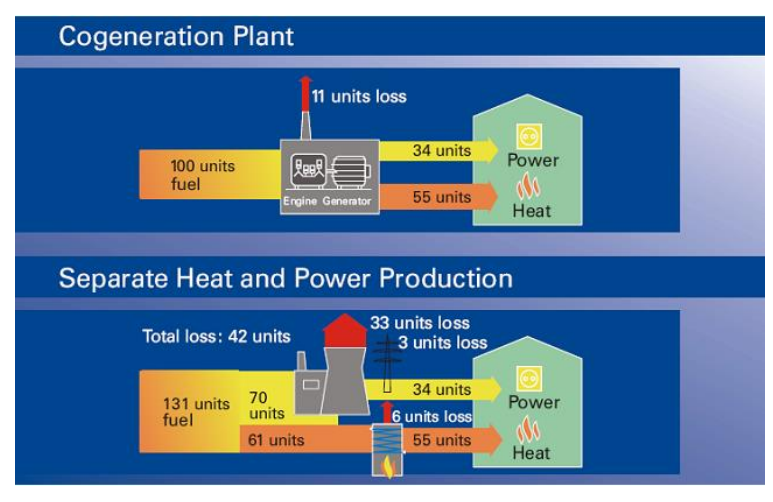

Figure 1.1 Technical principles of co-generation (European Union, 2008)

\subsection{Tri-Generation/Combined Heating, Cooling and Power (CHCP)}

Tri-generation, as the term describes, is an energy conversion process with combined heat, cooling and power (CHCP) generation. CHCP units consist of a CHP and a thermally driven chiller that utilizes the waste heat from the CHP unit. Depending on the demand, waste heat is fed to charge the chiller (during summer) or used as space heating (during winter). 
Tri-generation finds its application where simultaneous demand for electricity, heating and cooling occurs. The application area is vast ranging from small residential buildings to large commercial buildings, sports centres, airports, schools etc. Recently tri-generation in residential buildings is gaining popularity as the residential air conditioning system consumes substantial electricity from the grid. Tri-generation can help to reduce the air-conditioning load from the grid. However, during the winter season, the overall efficiency of the tri-generation system suffers due to no demand for space cooling which is one of the main drawbacks. Tri-generation systems are most suitable for pharmaceutical and food industries where there is simultaneous demand for electricity, heat and cooling throughout the year. Tri-generation can be classified in three different ways (European Union, 2008); namely: decentralized tri-generation, centralized CHPs with decentralized cooling and centralized CHCP systems.

\subsubsection{Decentralized Tri-generation}

As shown in Figure 1.2, this type of tri-generation system produces heating and cooling which is consumed onsite while the electricity is consumed either onsite or fed to the grid. As heat energy and cooling needs not to be transported in this type of system, it is efficient in terms of distribution costs and losses.

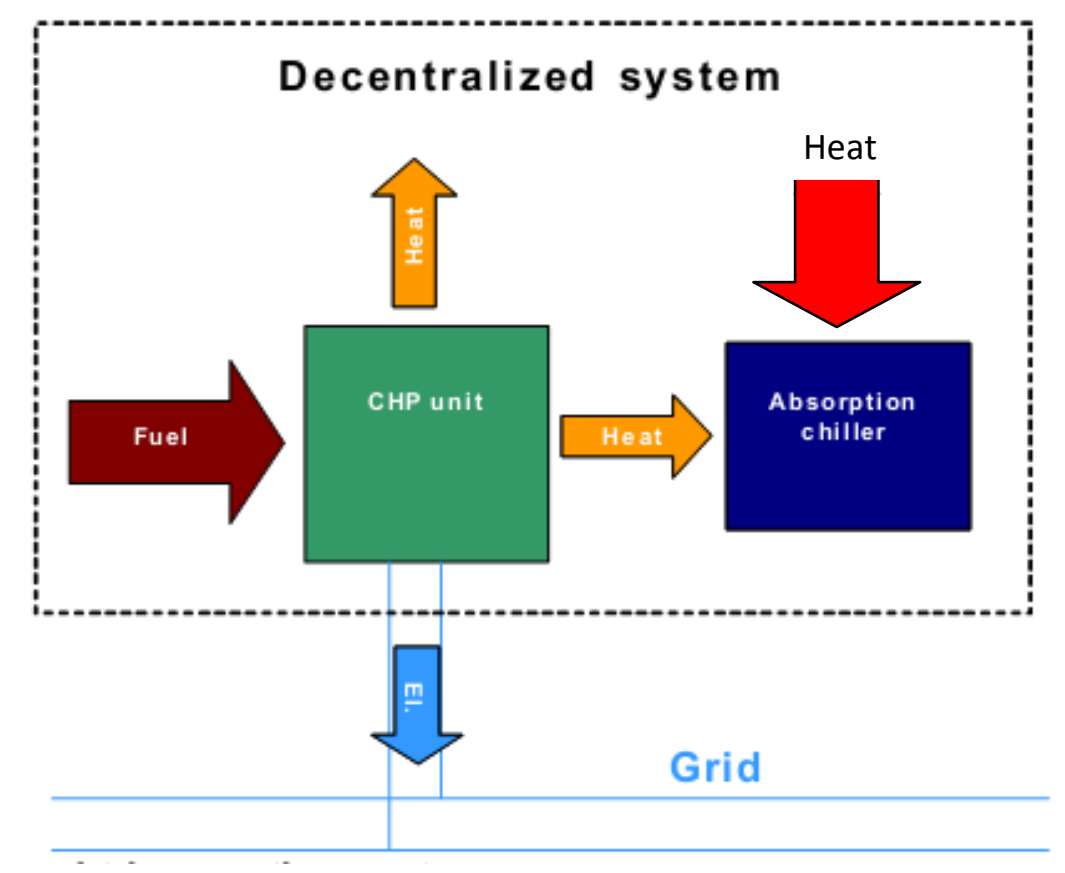

Figure 1.2 Decentralized tri-generation systems (European Union, 2008) 


\subsubsection{Centralized CHPs with Decentralized Cooling}

As shown in Figure 1.3, in this type of tri-generation system, electricity and heating is produced centrally and distributed to the end users while generation of cooling is decentralized. End users can consume heating from the district heating network and charge their thermally driven chillers whenever required. However, this type of system has major drawbacks during the peak cooling season, which can as be listed below (European Parliament of the Council, 2000):

- In a district heating network, normally the supply temperature of water is around 70$75^{\circ} \mathrm{C}$. Due to the lower supply temperature, the COP of the tri-generation system falls drastically. Moreover increasing the supply temperature is not suitable from the economic point of view.

- Low supply water temperature causes a 5-10 K temperature drop across the chiller, which means a high water flow rate is required to charge the chiller. A high flow rate is not desirable due to hydraulic instability and it also affects the power generation.

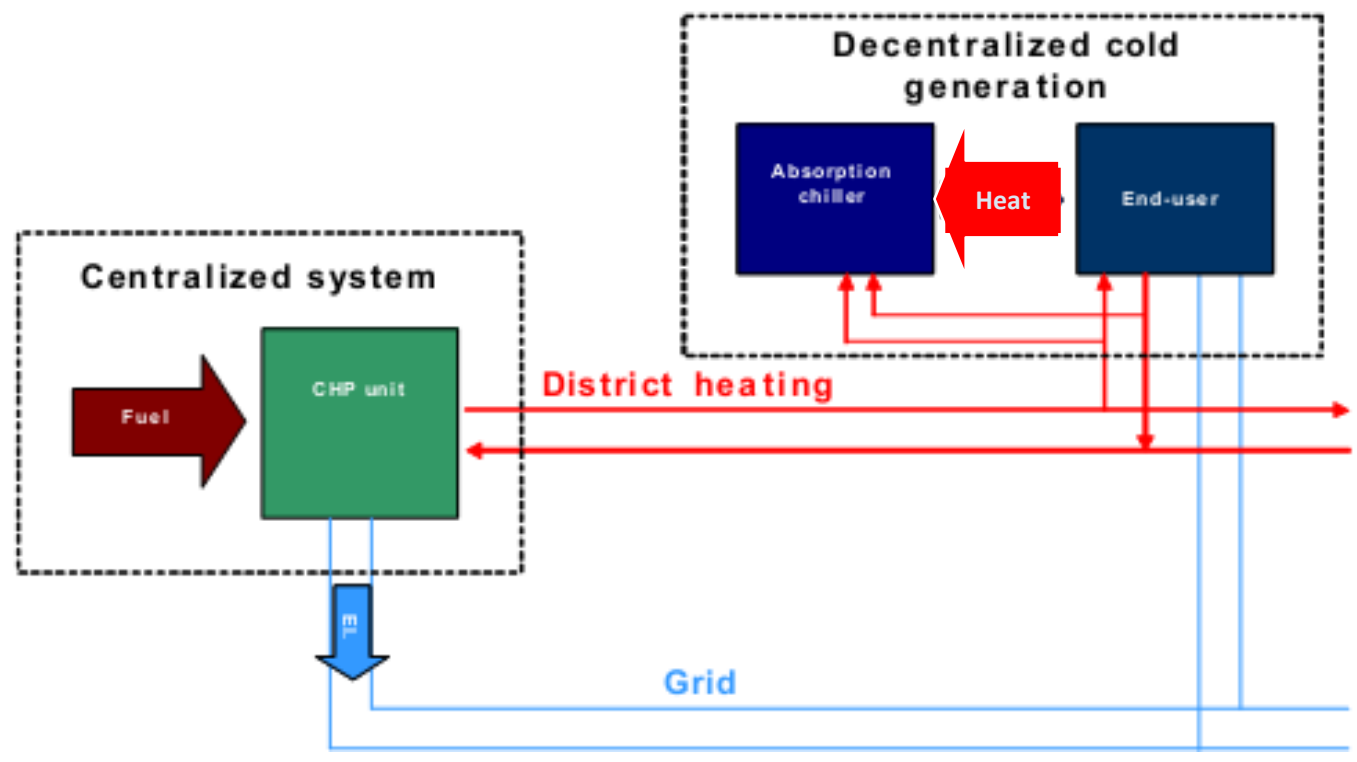

Figure 1.3 Centralized CHP with decentralized cooling (European Union, 2008) 


\subsubsection{Centralized CHCP systems}

In this type of configuration as shown in Figure 1.4, electricity, cooling and heating are generated centrally. The district heating and cooling network supplies heating and cooling to the end users. This type of system is associated with high initial cost as well as high distribution and transmission losses. However, installing a district cooling network with a district heating network is non-profitable as the cooling network would serve for limited urban areas, offices and residential buildings. This type of network is suitable for a small neighbourhood or community. Finally, even though this type of network is less costly, it is the most inefficient system.

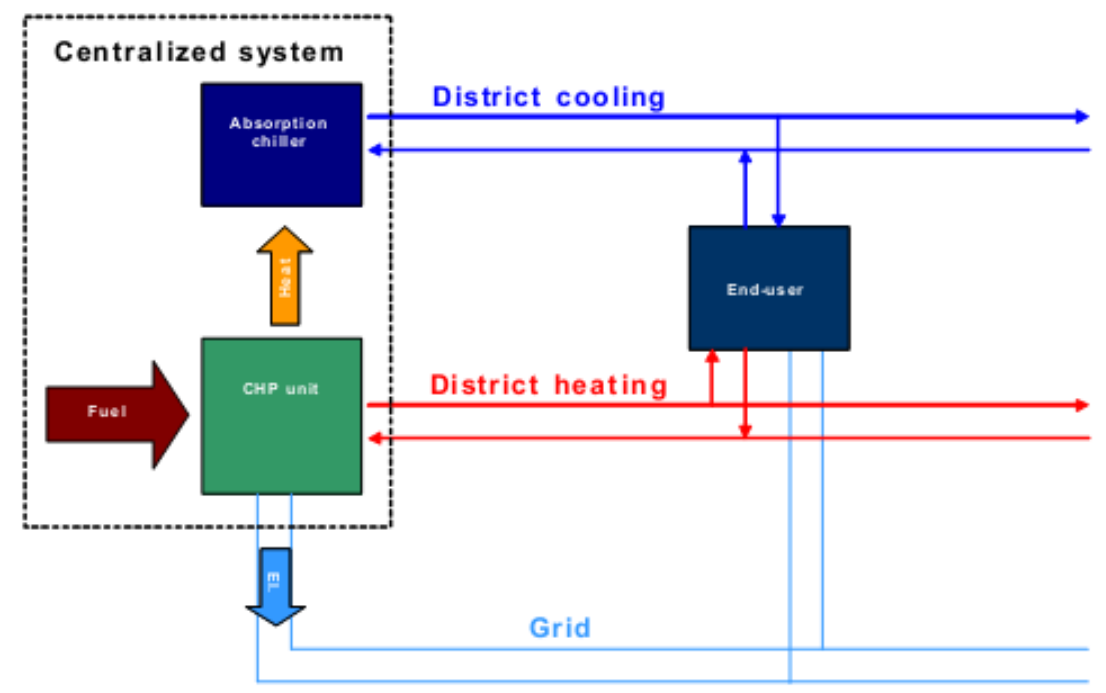

Figure 1.4 Centralized CCHP systems (European Union, 2008)

\subsection{Objectives}

A Stirling engine based micro CHP unit is already in service at House-B of the TRCA. A ClimateWell $^{\circledR}$ chiller was installed and coupled with the existing CHP unit to build a trigeneration system. Figure 1.5 shows a simple block diagram of the integrated system. 


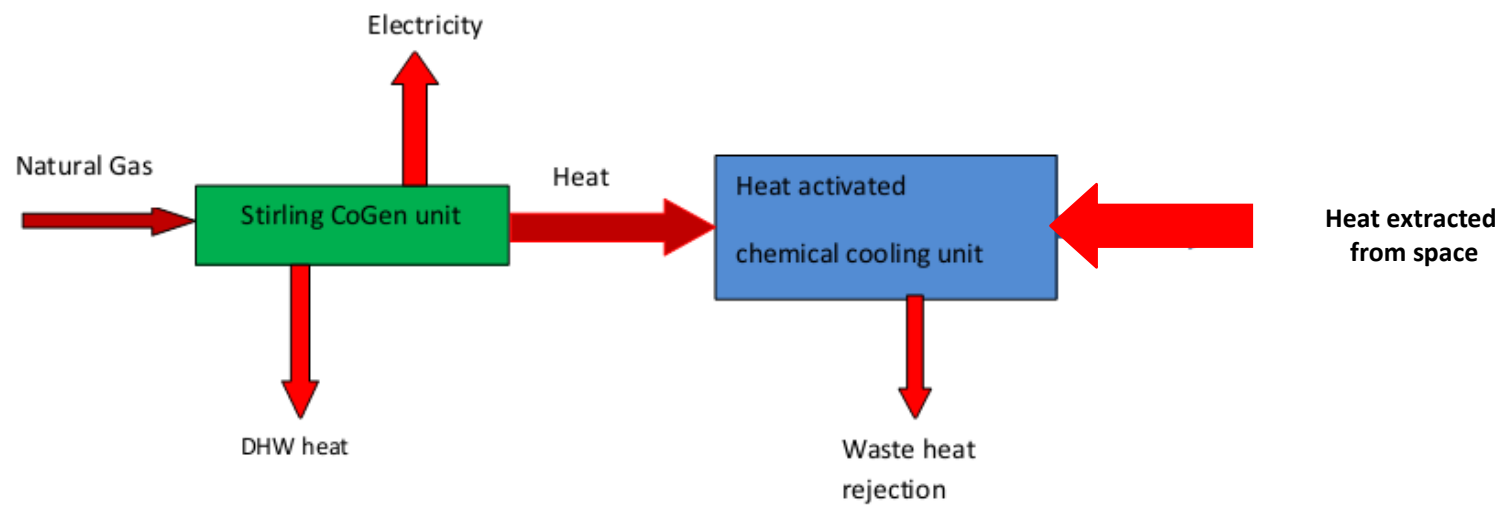

Figure 1.5 Block diagram of the integrated system

The main objective of this thesis is to present the design, installation, commissioning work and analysis of experimental and simulation results of the installed tri-generation system. The specific objectives of this thesis can be listed as below:

- Understand the working principle of absorption, adsorption and ClimateWell ${ }^{\circledR}$ technology.

- Develop a detailed design of a residential tri-generation system based on a gas fired CHP unit and ClimateWell ${ }^{\circledR}$ technology.

- Development of a detailed design for a multi-tank cascade storage system to produce DHW by utilizing the waste heat from the tri-generation system.

- Discuss the installation and commissioning work of the tri-generation system, DAQ, SQL.

- Collect data from all of the related sensors of the tri-generation system.

- Analyze the collected data to evaluate the performance and efficiency of the trigeneration system.

- Develop a TRNSYS model for the tri-generation system and multi-tank cascade storage system.

- Simulate the tri-generation system using the TRNSYS model for different input conditions and compare the results with the experimental data. 


\section{Chapter-2}

\section{Literature Review}

The literature review of this thesis is divided into three parts. The first part deals with the micro scale CHPs for residential buildings and houses. In the second part, previous works related to combined heating, cooling and power ( $\mathrm{CHCP}$ ) will be discussed. The third part deals with the previous works related to the multi-tank storage system for heat rejection purposes.

\subsection{Micro CHPs for Residential Applications}

Bernotat \& Sandberg (2004) studied the prospective of using micro CHPs for clustered dwellings. They concluded in their work that micro CHPs are suitable for clustered houses if the total heat demand is high enough.

Accadia et al. (2003) carried out an investigation on the possibilities of residential micro-CHP systems. Their work was related to micro co-generation $\left(<15 \mathrm{~kW}_{\text {Electrical }}\right)$ for residential and commercial applications. They worked to find a match between the size of micro CHPs and thermal and electrical demand of the house. The authors indicated fuel cell based CHPs as promising for residential and commercial applications in their work.

Hawkes and Leach (2007) worked on the optimization of micro CHPs in terms of installation and operating cost. Their work did not focus on optimizing the system in terms of thermal or electrical demand. The authors concluded that the lowest-cost operating strategy for CHPs is to follow electricity and thermal demand during the winter season.

Paepe et al. (2006) recently evaluated five micro CHP systems $(<5 \mathrm{~kW})$ for residential applications. They concluded that all CHP systems can save energy and reduce $\mathrm{CO}_{2}$ emission when they are operated on thermal demand. However, their work also concluded that installing a micro CHP in residential homes is not financially viable due to the high installation cost and the long payback period. Therefore, developments of low-cost micro-scale CHPs with innovative technologies are urgently needed. 
Podesser et al. (1998) studied the Stirling-engine based CHP technologies for residential usage and Huppmann (2000) worked on the fuel cell based co-generation systems for residential applications. In both studies, the authors concluded that fuel-cell based CHPs are not cost effective for residential and small scale applications.

In the UK, a field trial for residential CHP systems was initiated in 2003 by the Carbon Trust. A prototype of residential CHP systems was installed throughout the representative homes during 2004 and 2005, and an interim report on the preliminary results was published at the end of 2005 (Carbon Trust, 2005). The conclusion of this report was, "performance is not as encouraging as had been hoped based on published modelled performance of the technology at the outset of the trial". The interim report identifies the reasons for disappointing results as:

- The actual, real world efficiency of the units is lower than assumed by the existing modeling exercise.

- The amount of electricity generated is much lower than forecasted.

- Electricity exported out of the building is considerably lower than expected.

The lower efficiency and lower amount of electricity production were concluded to be related to the design and operation of the prototype units. Entchev et al. (2004) noticed similar results as in a separate field study.

In 2003, a WishperTech CHP unit was tested in the CCHT house in Ottawa. Thermal energy produced by the CHP was used for space heating and DHW production. The engine was always controlled to perform full operating cycles (warm-up, normal operation, shut-down and inoperation) and was not allowed to shut down before the full shut down phase ended. The data gathered during this test period were used to calibrate the CHP model developed by Ferguson and Kelly (2006). Ferguson (2006) describes details about the calibration procedure for CHP systems.

Peacock et al. (2005) studied the Stirling engine based CHPs for residential applications. His work concluded that Stirling engine based CHPs are suitable for residential buildings for low electricity/heat ratio. His work also suggested that for a larger electricity/heat ratio, Stirlingengine based CHPs are more suitable for backup power than for continuous use. 


\subsection{Literature Review on CHCP Systems}

A general review of CHCP systems was given by Wu et al. (2006). Wu et al. first described the term CHCP. The study gives a brief description and review about the state-of-the art in CHP and TDC technologies, including their drawbacks and advantages. This review is not limited to a specific size. Typical CHCP configurations are given, including large systems that are suitable for power plants or large industrial applications. Regarding micro-CHCP systems, a limited market and development is recognized. Sectors for small-scale systems are given, like retail stores, hospitals, supermarkets, etc. mainly in the USA. Moreover, examples for medium size (1$10 \mathrm{MW}$ ) systems, and a large system (> 10MW) at the University of Illinois (complex system with several chillers etc.) are given. The authors also presented a review about the developments around the world in terms of a historic review and the current situation. The authors summarized the current situation about CHCP research in the USA, Europe, Asia and the Pacific (China, Japan, India, and ASEAN) and other countries. Unfortunately, this paper gives only very little information about micro-CHCP systems.

Bronson (2003) described the CHCP technology and its potentials in general. Klein et al. (2006) investigated general advantages of $\mathrm{CHCP}$ systems regarding energy consumption, environmental issues and other pollutants.

Nelson et al. (2009) analysed the energy use in the three operation regimes of CHCP, Pure CHP, and a combination of CHCP and CHP. In each case the authors derived mathematically that the energy consumed on site (sum of electricity, primary energy for fuel) increases for a CHCP as compared to a reference system with a vapour compression chiller and separate boilers.

Kong et al. (2004) dealt with the energy efficiency and economic feasibility of a small scale $\mathrm{CHCP}$ system powered by an available Stirling engine. Compared to contemporary conventional independent cooling, heating and power production; the authors concluded that the CHCP system saves fuel resources and has the assurance of economic benefits.

Gea et al. (2009) validated a TRNSYS model against a test rig of a CHCP system. Focus was put on the application in supermarkets. The main components were the Robur absorption chiller and a CHP of the Micro Gas Turbine (MTG) type. 
The report of Bian et al. (2005) presented a dynamic model of an absorption chiller working in a CHCP system, in order to study the transient thermal behaviour of the chiller. In the report, the authors presented that, it took about 15 minutes to reach $50 \%$ of its cooling capacity, and 60 minutes to reach the full capacity.

Godefroy et al. (2007) in their work discussed the design and analysis of possible CHCP systems based on gas engines. The mathematical modeling of a small scale CHP and cooling system are presented in their study.

Piacentino et al. (2007) published several papers on optimization of small scale energy systems operated with variable loads and variable energy prices. The authors used linear and non-linear programming computer aided mathematical models to optimize the synthesis, design and operation of the tri-generation systems. Authors also developed an optimization model based on economics and environmental analysis.

Plura et al. (2005) presented a double effect absorption chiller that was specially designed to couple with CHP systems with a heat source at two different temperature levels. The authors mentioned this overall system could increase the COP of a tri-generation system up to 1.0.

Pilatowsky et al. (2007) developed a simulation for a CHCP system based on absorption chiller and proton exchange membrane fuel cell. The authors concluded that fuel cell based CHCP systems have COP around 0.44-0.57.

Minciuc et al. (2003a) described a method to analyze the $\mathrm{CO}_{2}$ emission and energy savings of CHCP systems focusing on gas turbines and IC engines. The authors concluded that the efficiency in the electricity generation in cogeneration mode is the same for the non cogeneration mode. Minciuc et al. (2003b) in another work focussed on the coupling of gas turbines or IC-engine based CHPs with an absorption chiller.

In Europe, during 2006-2009, an earlier version of the ClimateWell ${ }^{\circledR}$ chiller was used in different projects on a test basis. A brief description about some of those projects are included in Appendix-A. 


\subsection{Literature Review on Multi-Tank Systems}

Bejan in 1982 first introduced the idea of divided storage or multi-tank systems in an effort to reduce the entropy generation. His idea consisted of dividing a thermal energy system into a set of subsystems that are in local thermodynamic equilibrium with other (Bejan et al., 1999). Taylor and Krane (1991) investigated Bejan's work (1982) in analytical study and agreed that it is possible to design a distributed/multi-tank storage system without seriously degrading the thermodynamic performance.

Ragoonanan et al. (2006) demonstrated the benefits of dividing an indirect thermal storage unit into two components. As shown in Figure 2.1, the dual component storage tank consisted of an equally divided rectangular storage vessel and a copper heat exchanger immersed in the storage fluid. The heat exchanger flow path was in series through the two compartments resulting in a staged heating process. It was found from the study that the heat exchanger outlet temperature was higher than it would be using the same heat exchanger in an undivided storage. The authors also studied the energy delivery of this system and found that the divided storage delivered a maximum of $11 \%$ more energy than the undivided storage.

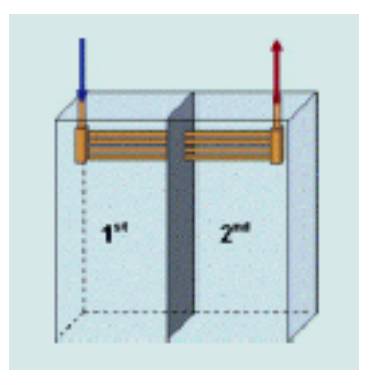

Figure 2.1 Divided indirect integral collector storage with two storage compartments (Ragoonanan et al., 2006)

Boies and Homan (2008) investigated the limiting behaviour of a single element thermal storage and in integral collector storage system as shown in Figure 2.2. The authors compared the performance of perfectly stratified and fully mixed single element storage with the performance of a multi-element storage of equal size. It was found from the study that, dividing the storage volumes into separate sections significantly improves the discharge characteristics. Authors also 
noted that in many cases, the performance of multi-element storage is similar to a single perfectly stratified storage system.

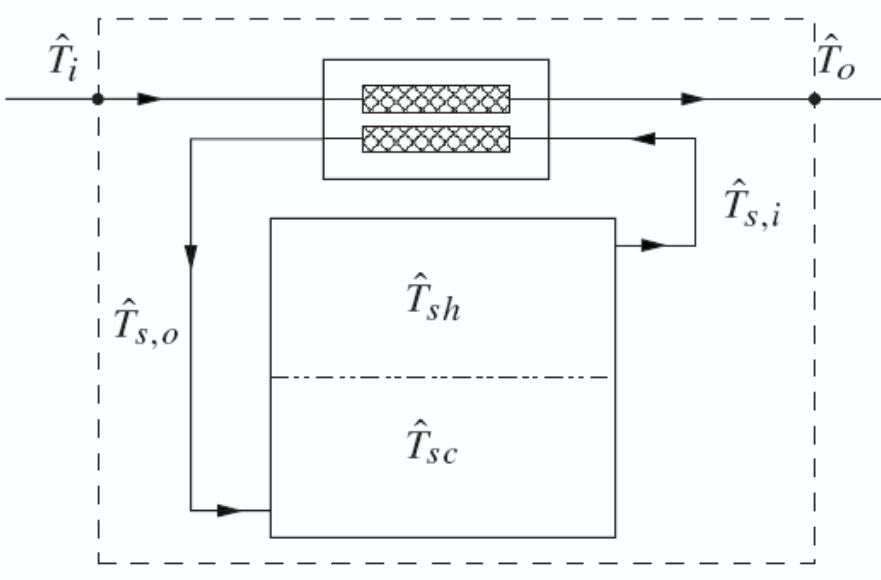

Figure 2.2 Schematic of an integrated collector storage system composed of a single perfectly stratified storage element and a counter flow heat-exchanger (Bois and Homan, 2008)

Sekulic and Krane (1992) investigated the thermal efficiency of a multi-tank sensible heat storage system. In this study, the author worked on a two-tank system connected in series with internal immersed heat exchangers. The authors concluded that this system has entropy generation up to $38 \%$ less than the corresponding single tank system and thus has higher thermodynamic efficiency.

Mather et al. (2002) investigated multiple thermal storage tanks plumbed in series manner with immersed coil heat exchangers at the bottom of each tank, as shown in Figure 2.3. In this system, the heat exchangers for charging the tanks were located at the bottom of each tank while those for discharging were located at the top of each tank. 


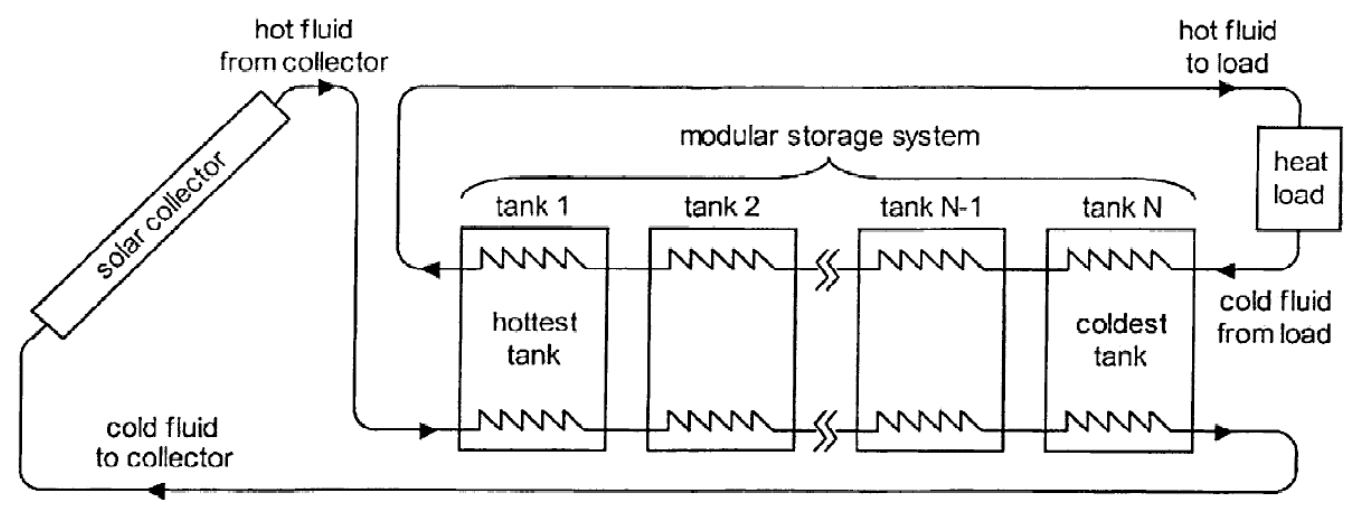

Figure 2.3 Multiple DHW tanks with immersed coil heat exchangers connected in series

\section{configuration}

As shown in Figure 2.3, the multi-tank storage system was charged and discharged in a counterflow configuration. As a result, a thermal diode effect could be achieved such that each individual heat exchanger only delivered heat energy to the tank and would not transfer heat from a hot tank to a cold tank. As a result a stratified thermal storage system is achieved. In this thesis, the configuration of a multi-tank system as discussed, has been adopted to produce DHW by utilizing the rejected heat from the ClimateWell ${ }^{\circledR}$ chiller.

Tachhi (2003) proposed a new modular tank and piping arrangement for thermal storage applications. The storage system consisted of multiple superimposed horizontal tanks featured with an innovative network of pipes that allowed the upper and lower part of each tank to connect with the upper and lower part of the adjacent tank, respectively. The authors showed in their study that this system facilitates natural convection inside the tanks and suppresses mixing.

Cruickshank and Harrison (2006) showed a comparative study between series and parallel thermal storage tanks. As shown in Figure 2.4, the authors mentioned in their work two possible ways of parallel connection, namely: the Tichelman Ring (Peuser et al., 2002) and branched configuration. Authors also mentioned that in Tichelman Ring configuration, there are problems in balancing the flow through the three heat exchangers. As mentioned by the authors, the Tichelman ring configuration is sensitive to friction losses through the piping (e.g., surface roughness, solder connections, elbows and other constrictions) which result in flow imbalance. The authors concluded that for parallel connection of multi tanks, branched configuration is better than the Tichelman Ring configuration. 


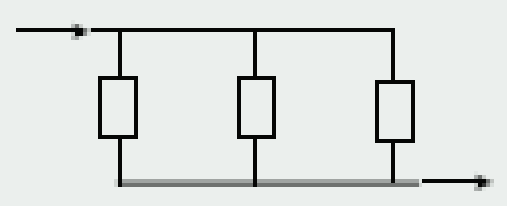

(a)

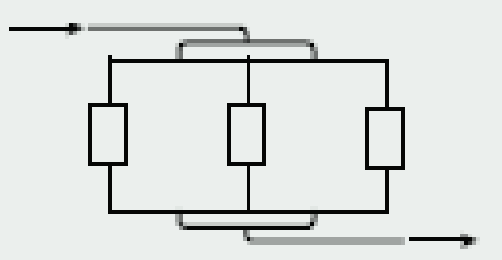

(b)

Figure 2.4 Schematic of two parallel connection configurations (a) Tichelman Ring (Peuser et al., 2002) (b) Branched 


\section{Chapter-3}

\section{Absorption, Adsorption and Thermo-chemical Accumulation (TCA)}

In this chapter, different heat driven refrigeration systems will be discussed in detail. Advantages and disadvantages of different refrigeration systems from the viewpoint of residential trigeneration are also incorporated here. This chapter contains a broad description about the ClimateWell ${ }^{\circledR}$ chiller that has been used in this residential tri-generation project.

The most widely used refrigeration and air-conditioning systems at present are based on the vapour compression cycle (Maiya et al., 1998). This is because they are relatively inexpensive and their technology is well established. The vapour compression cycle is associated with high energy consumption (mechanical and electrical) which is one of its major drawbacks. Moreover, increasing scarcity of natural resources, blackouts resulting from weather events and increasing in cooling needs due to global warming are compelling us to search for an alternative solution to meet summer cooling demand. In addition, recent discoveries show that the working fluids used in vapour compression system cause ozone layer depletion and/or global warming.

In recent years, researchers have aimed to replace vapour compression systems by technologies that can offer lower energy consumption without affecting comfort level. An alternative to the vapour compression system is the thermally driven chiller (TDC), which can be driven by solar thermal or low grade waste heat. TDCs are usually operated in a vapour sorption refrigeration cycle. The interest in vapour sorption refrigeration systems first started in the 1970s due to the oil crisis and then later resurfaced in the 1990s due to the ecological effect associated with CFCs and HCFCs as refrigerants (Stephan, 1982). TDC is one of the major components of combined heating, cooling and power (CHCP) systems/tri-generation systems (Nurez et al., 2010). It produces a chilling effect utilizing waste heat from a combined heat and power (CHP) unit.

Sorption refrigeration systems are old refrigeration technology which dates back to the 1770s, when sulphuric acid was used as a working fluid. Later in 1990s, the ammonia and water $\left(\mathrm{NH}_{3^{-}}\right.$ $\mathrm{H}_{2} \mathrm{O}$ ) working pair became popular in sorption refrigeration systems (Stephan, 1982). Vapour sorption systems are mainly of two types, namely: absorption systems and adsorption systems. In absorption systems, the absorber is usually a liquid whereas in adsorption systems, solid 
substances are used as the adsorber. The adsorption process is associated with the separation of refrigerant from one phase to another, accompanied by its accumulation on the surface of the adsorber. Absorption is the process in which material is transferred from one phase to another, (e.g., liquid), which interpenetrates the second phase to form a solution (International Absorption Society, 2012). An absorption chiller that uses salt and water as the working pair and has internal thermal storage capacity, is known as a thermo-chemical accumulator (TCA) or chemical heat pump (Nurez et al., 2010). It is a quite new and promising technology that stores thermal energy in the form of crystallized salt.

Figure 3.1 shows classification of refrigeration systems in general. In this project, the absorption chiller used is known as the Climatewell ${ }^{\circledR}$ absorption chiller. It is a salt-water $\left(\mathrm{LiCl}-\mathrm{H}_{2} \mathrm{O}\right)$ based absorption system that also has internal storage capacity. Thus, it falls under the category of TCA.

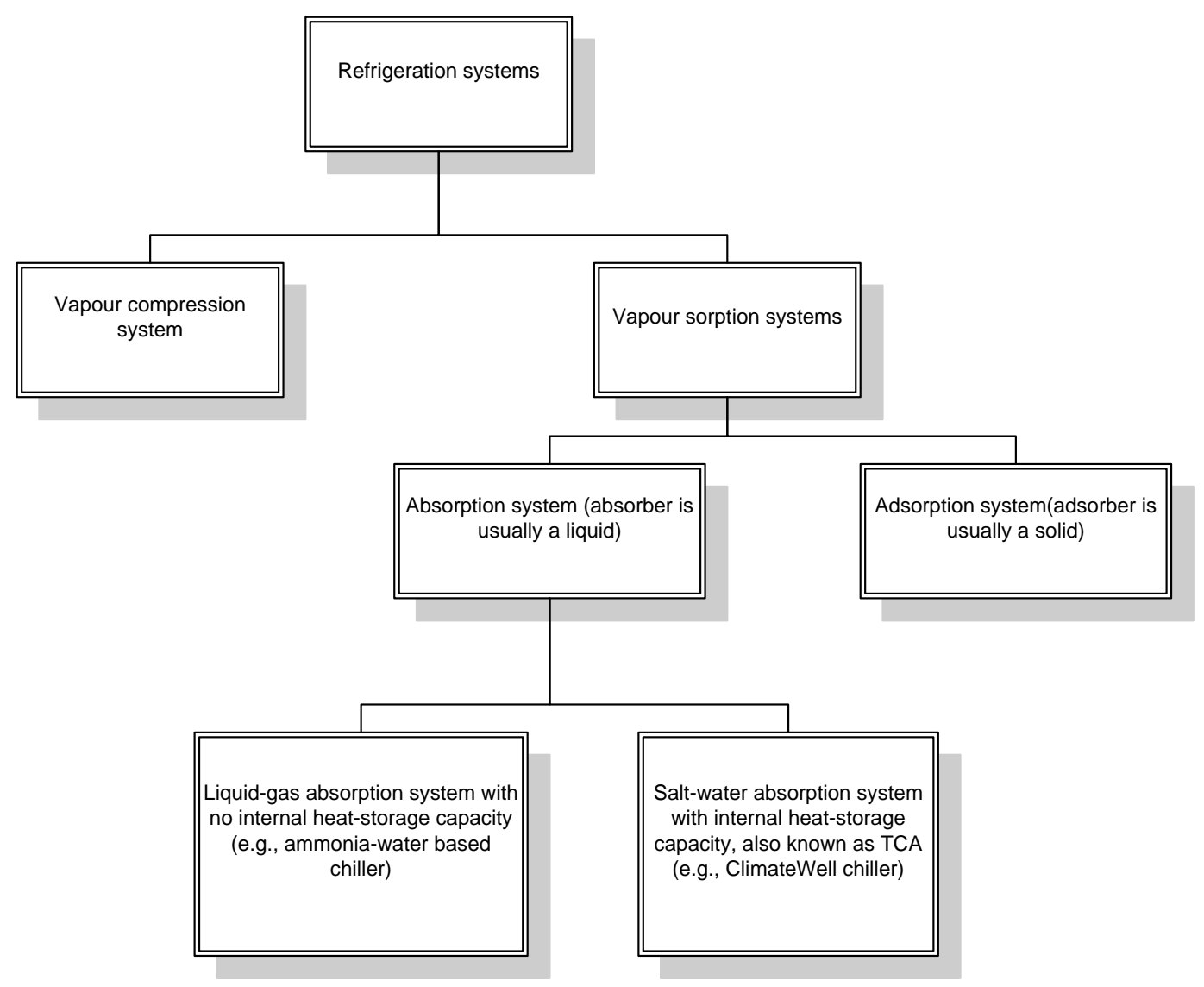

Figure 3.1 Classifications of refrigeration systems (Nurenz, 2010) 


\subsection{Absorption Refrigeration System}

Ancient civilization was entirely dependent on the natural ice from the north for their cooling needs. The early development of absorption technology dates back to the 1770's, when people knew that ice could be produced by evaporating water contained in an evacuated container in the presence of sulphuric acid (Herold \& Radermacher, 1989). But this technology did not gain much popularity due to the corrosion problem associated with $\mathrm{H}_{2} \mathrm{SO}_{4}$. Also, this method of producing ice was expensive as highly concentrated $\mathrm{H}_{2} \mathrm{SO}_{4}$ was needed for each batch of production.

During the civil war in the mid-1880s, the Americans of United States were in trouble due to being cut off from a supply of ice from the north. In 1860, a Frenchman named Ferdinand Caree invented an ice making machine that used $\mathrm{NH}_{3}-\mathrm{H}_{2} \mathrm{O}$ as a working fluid (Stocker \& Jones, 1983). This machine gained much popularity as it overcame the corrosion problem that was associated with the $\mathrm{H}_{2} \mathrm{SO}_{4}$. This commercial ice-making machine gained a U.S. patent at that time. Later due to the development of cheap, electrically driven compressors, absorption systems became a niche technology (Stephan, 1982). In recent times, most residential and commercial buildings use a vapour compression refrigeration system as it is cheap, compact and readily installable. The main drawbacks associated with absorption refrigeration systems are: high initial cost, low COP, heavy weight and bulky size. Moreover absorption systems are operated under vacuum conditions, which can be a regular maintenance problem. In spite of having these drawbacks, vapour absorption systems have gained interest over the last few decades due to their use of environment friendly working fluids. Recent discoveries show that CFCs and HCFCs used as the working fluids in vapour compression systems cause ozone layer depletion and are strong greenhouse gases. Absorption cycles can be operated at different driving temperatures as low as $50^{\circ} \mathrm{C}$ (Deng et al., 2011). As an absorption system does not require any moving parts, it is suitable for locomotives, buses and spacecraft, as its performance is not affected by vibration.

\subsubsection{Working Principle of Absorption System}

The three main components of a refrigeration cycle are: the condenser, expansion valve and evaporator, as shown in Figure 3.2. The refrigerant fluid evaporates at low pressure in the evaporator and thus produces a cooling effect. To continue this process, low pressure refrigerant 
vapour needs to be compressed to high pressure vapour and transferred back to the condenser. This work is done by a mechanical compressor in a vapour compression system, while in an absorption system, this process is carried out by combining the generator and absorber. Figure 3.3 shows a typical absorption system with four main components. The working principle of an ideal absorption cycle is described below with a P-T diagram, as shown in Figure 3.4.

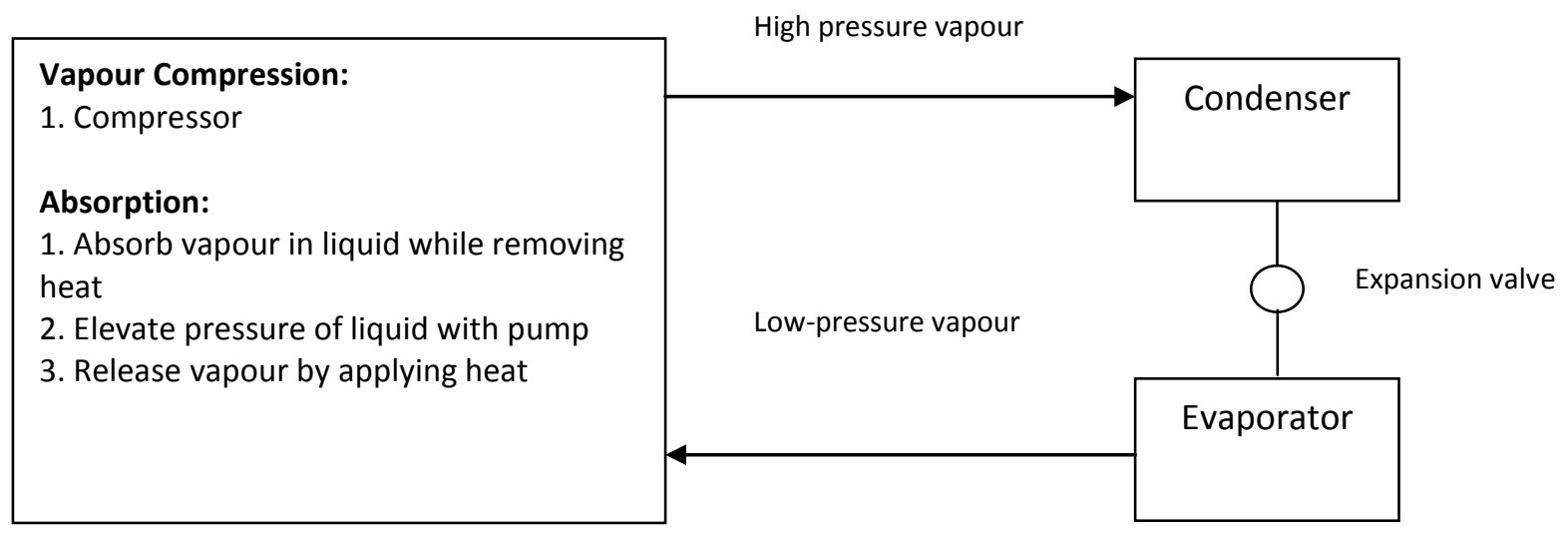

Figure 3.2 working principle of a refrigeration cycle (Stocker \& Jones, 1983)

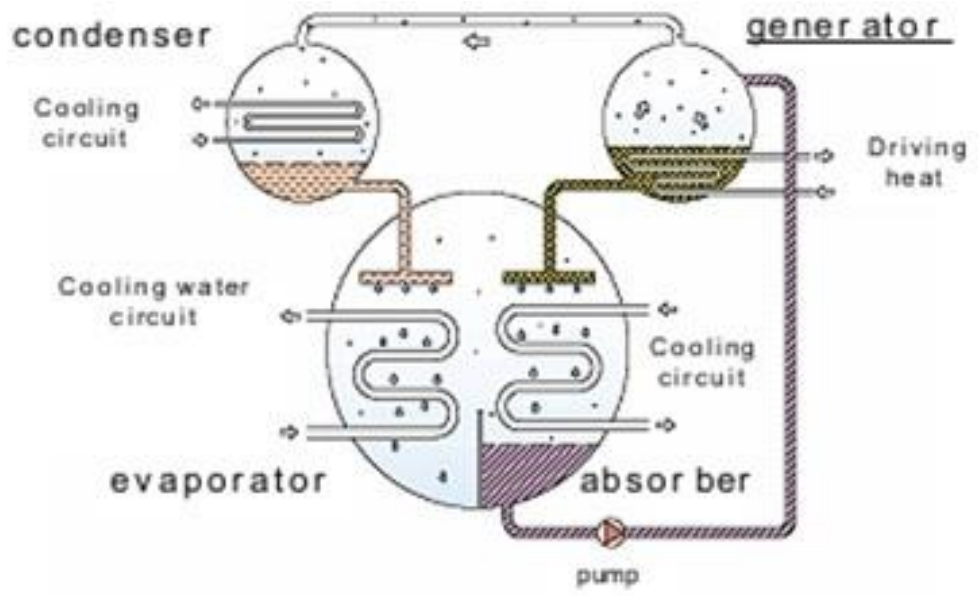

Figure 3.3 Ideal absorption refrigeration cycle (Nurenz et al., 2010) 


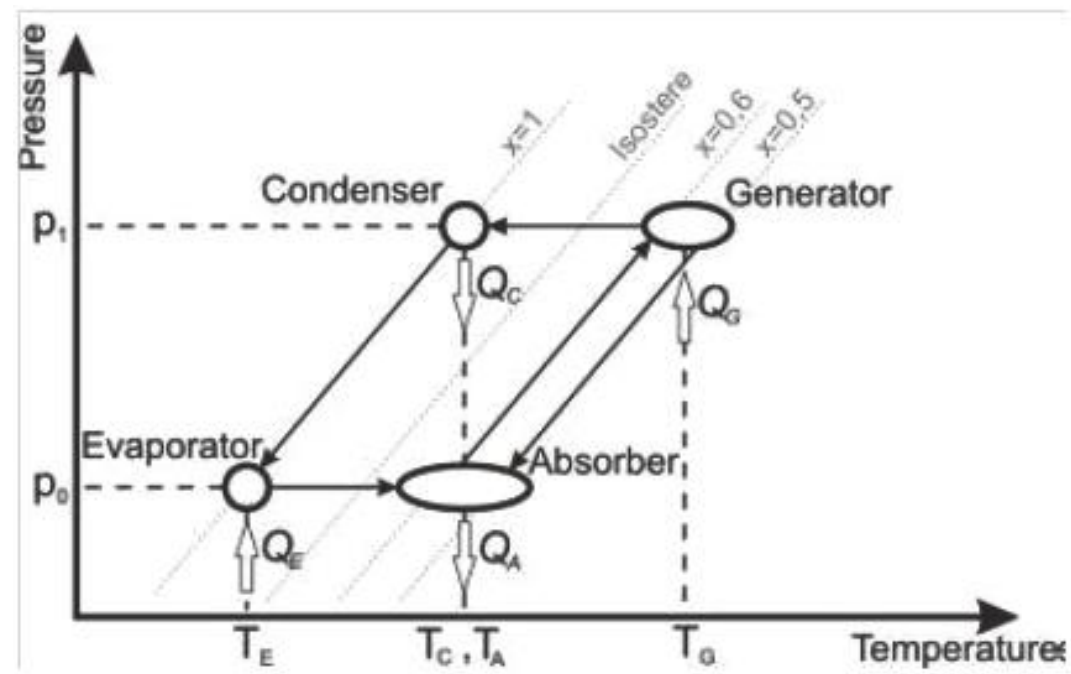

Fig. 3.4 Pressure-temperature diagram of ideal absorption cycle (Nurenz et al., 2010)

A working pair of an absorption system is composed of two different fluids having different boiling points. The one with lower boiling point is known as the refrigerant and the one with higher boiling point is the absorbent. Figure 3.4 shows a P-T diagram of an absorption cycle. Heat energy $\mathrm{Q}_{\mathrm{G}}$, from an external source at a temperature, $\mathrm{T}_{\mathrm{G}}$, is supplied to the tube of the generator that is in contact with the strong solution. High temperature flow inside the tube causes the solution to boil. As the refrigerant has a lower boiling point, the high temperature causes refrigerant to transform to vapour and get separated from the absorbent which remains in the liquid phase. This process of separation of refrigerant from absorbent is known as desorption. At the end of the desorption process, refrigerant vapour enters to the condenser where it rejects heat, $\mathrm{Q}_{\mathrm{C}}$, and is transformed to the liquid phase again. Liquid absorbent from the generator is pumped back to the absorber at the end of the desorption process.

Condensed refrigerant from the condenser enters the evaporator where a low pressure is maintained. Liquid refrigerant in the evaporator absorbs heat, $\mathrm{Q}_{\mathrm{E}}$, from the space (that is to be cooled) and is transformed to the vapour phase. As a result, the evaporator maintains a lower temperature, $\mathrm{T}_{\mathrm{E}}$. Refrigerant vapour from the evaporator then enters into the absorber where it is absorbed by liquid absorbent. During the absorption process, refrigerant vapour releases condensation energy, $\mathrm{Q}_{\mathrm{A}}$, and is transformed to the liquid phase. At the end of the absorption process, the strong solution from the absorber is pumped into the generator and thus the cycle 
continues. In the absorption system, both the generator and condenser maintain a higher pressure while a vacuum pressure is maintained inside the evaporator and the absorber. An absorption cycle is much simpler in comparison to a vapour compression cycle. It does not contain any moving parts, except the circulation pumps.

\subsubsection{Working Pair of Absorption System}

Selecting a suitable working pair is one of the important factors in absorption refrigeration systems. The efficiency of an absorption cycle largely depends on the properties of the working pair and the operating pressure (Prez-Blanco, 1984). Some important thermo-physical properties of the working pair are: solubility of refrigerant, surface tension of the solution, heat of solution and thermal conductivity of the refrigerant and solution (Holemberg \& Berntsson, 1990). The two most widely used working pairs for absorption refrigeration systems are ammonia and water $\left(\mathrm{NH}_{3}-\mathrm{H}_{2} \mathrm{O}\right)$ and lithium bromide and water $\left(\mathrm{LiBr}-\mathrm{H}_{2} \mathrm{O}\right)$. Each of the working pairs has certain advantages and disadvantages (Fan et al., 2007). Ferdinand Caree first used $\mathrm{NH}_{3}-\mathrm{H}_{2} \mathrm{O}$ as a working pair for absorption refrigeration in 1859, thereby earned the first U.S. patent for commercial absorption unit in 1860 (Deng et al., 2011). $\mathrm{NH}_{3}-\mathrm{H}_{2} \mathrm{O}$ is generally used for refrigeration and industrial application as it has an evaporator temperature below $0^{\circ} \mathrm{C} . \mathrm{LiBr}-\mathrm{H}_{2} \mathrm{O}$ was first used as working pair for absorption system in 1950's (Srikhirin et al., 2001). Because water is the refrigerant in the working pair, the $\mathrm{LiBr}-\mathrm{H}_{2} \mathrm{O}$ system has evaporator temperature above $0^{\circ} \mathrm{C}$, which makes it suitable for air-conditioning purposes.

\subsubsection{Evaluation of Absorption Refrigeration System for Residential Tri-generation}

For residential tri-generation purposes, $\mathrm{NH}_{3}-\mathrm{H}_{2} \mathrm{O}$ systems are not recommended due to the corrosive and toxic nature of $\mathrm{NH}_{3}$. Toxic $\mathrm{NH}_{3}$ can cause serious health problems due to the leakage of the pipelines. Moreover, CHP units commercially available for domestic applications supply heat at a temperature of $80^{\circ} \mathrm{C}$ and at this temperature, the $\mathrm{COP}$ of $\mathrm{NH}_{3}-\mathrm{H}_{2} \mathrm{O}$ system drops below 0.5 which reduces the overall efficiency of the tri-generation system.

A $\mathrm{LiBr}-\mathrm{H}_{2} \mathrm{O}$ system can be driven by a low temperature $\left(<80^{\circ} \mathrm{C}\right)$ heat source. That is why the pressure level associated with this type of system is quite low. This type of system is vulnerable to leakage which results in non-condensable gases entering into the system during the absorption process or because of corrosion. For residential applications, the $\mathrm{LiBr}-\mathrm{H}_{2} \mathrm{O}$, system is not 
recommended as it requires a purge system to operate on a daily basis to remove noncondensable gases. Moreover, crystallization is the other major problem associated with $\mathrm{LiBr}-$ $\mathrm{H}_{2} \mathrm{O}$, which occurs frequently due to improper purging, power failure or an inefficient heatrejection system.

\subsection{Adsorption Refrigeration System}

Adsorption systems are very similar to absorption systems, as shown in Figure 3.5. The main difference is that the sorbent is solid and not liquid. Adsorption is a physical process where the molecules of the refrigerant fluid bond to the surface of the adsorbent by weak Van-Der-Waals forces. Adsorption is a surface phenomenon as opposed to absorption where matter changes to a solution phase. Adsorbents that are used in chillers should have high porosity. The high porosity and extremely large surface area (several hundreds of $\mathrm{m}^{2}$ per gram of material) allows adsorbents to adsorb a significant amount of refrigerant. The main characteristic of the adsorbent-refrigerant pair is the amount of adsorbed refrigerant per unit of dry adsorbent. This phenomenon is known as a loading function $(\mathrm{x})$, which is the ratio of the mass of refrigerant $\left(m_{\text {refrigerant }}\right)$ to the mass of the adsorbent $\left(m_{\text {adsorbent }}\right)$. The loading function is dependent on operating temperature $(\mathrm{T})$ and pressure $(\mathrm{P})$.

$$
\mathrm{X}=\frac{m_{\text {refrigerant }}}{m_{\text {adsorbent }}}=\mathrm{x}(\mathrm{T}, \mathrm{P})
$$

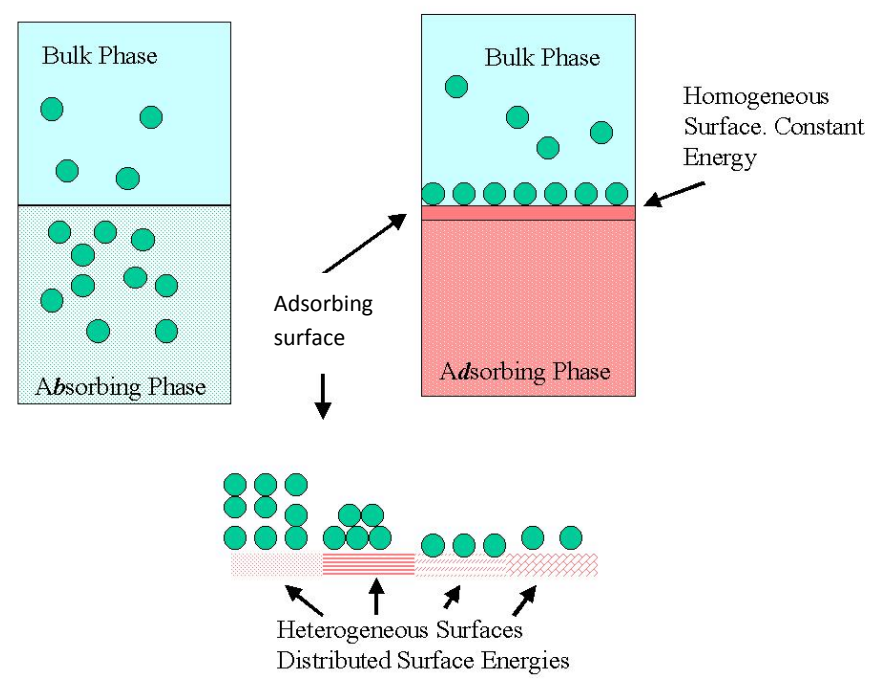

Figure 3.5 Comparison between absorption and adsorption system 


\subsubsection{Working Principle of Adsorption Refrigeration System}

As shown in Figure 3.6, the main components of an adsorption refrigeration cycle are: the condenser, the generator and the evaporator. During the adsorption process, the generator works as an adsorber and during desorption process, the generator works as a desorber. At the start of a desorption cycle, the desorber is loaded with saturated adsorbents. Heat energy, $\mathrm{Q}_{\mathrm{G}}$, is supplied from an external source at temperature $\mathrm{T}_{\mathrm{G}}$ that is above the boiling point of the refrigerant. High temperature causes the refrigerant to evaporate and get separated from the adsorbent. Evaporated refrigerant then enters the condenser via valve $\mathrm{V} 1$ where it releases condensation energy, $\mathrm{Q}_{\mathrm{C}}$, and transforms to the liquid phase. Thee desorption cycle continues as long as the adsorbents get dry and unsaturated. During the desorption cycle, condensation energy, $\mathrm{Q}_{\mathrm{C}}$, should be removed efficiently from the condenser in order to improve the COP of the cycle. At the end of desorption cycle, condensed liquid refrigerant is pumped to the evaporator. The desorption cycle is also termed as the charging cycle.

The adsorption cycle, which is also termed as the discharge process, starts as soon as the desorption process finishes. During the adsorption cycle, valve V1 remains closed while valve V2 remains opened. As low pressure is maintained in the evaporator, liquid refrigerant evaporates and the required energy for evaporation, $\mathrm{Q}_{\mathrm{E}}$, is taken from the space to be cooled. Evaporated refrigerant then enters the adsorber where it is adsorbed by the un-saturated adsorbents. The evaporated refrigerants release binding energy, $\mathrm{Q}_{\mathrm{B}}$, during the adsorption cycle and the process continues as long as all the refrigerant vapour is evaporated from the evaporator. 


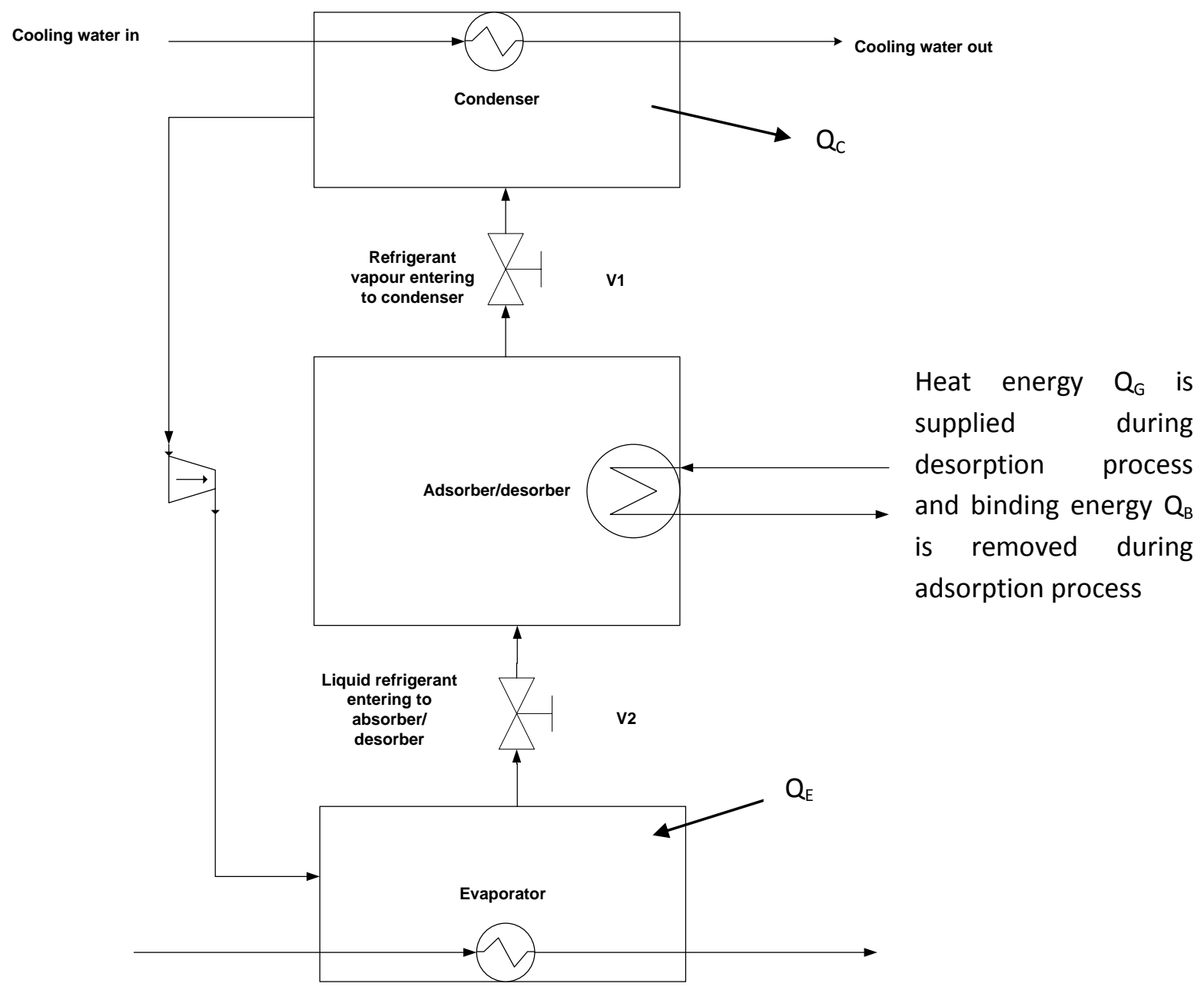

Figure 3.6 Working principle of an adsorption refrigeration cycle

The adsorption refrigeration cycle is a discontinuous process as the cooling effect is discontinuous. It produces a cooling effect only the during adsorption cycle. Generally the desorption cycle is longer than the adsorption cycle. However the process can be made continuous by adding another adsorber/desorber barrel in parallel with the existing one. Figure 3.7 shows an adsorption refrigeration system with two adsorber/desorber units in parallel. This addition makes the cooling effect continuous as the two adsorber/desorber barrels charge and discharge alternately. 


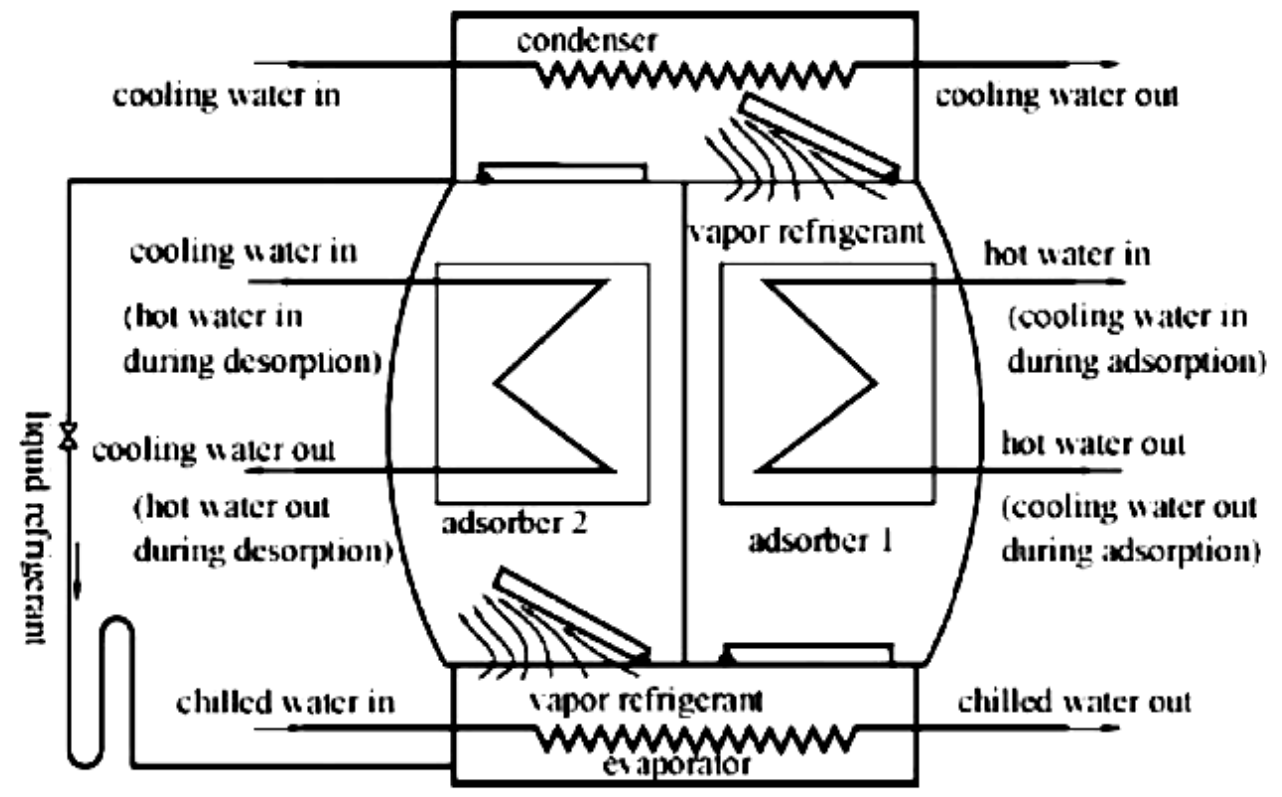

Figure 3.7 Adsorption refrigeration system with two adsorber/desorber barrels (Wang et al., 2010)

\subsubsection{Working Pair of Adsorption Refrigeration}

The most widely used working pair for adsorption refrigeration system is silica-gel and water. A wide range of other working pairs are also used for adsorption refrigeration systems. According to the principle of the cycle, the adsorbent should have characteristics of large adsorption capacity, large variation of adsorption capacity with temperature and good compatibility with the refrigerant. For the refrigerant, the requirements are high latent heat per volume, non-toxicity, non-flammability and good thermal conductivity (Wang et al., 2010). Some of the widely used working pairs for adsorption refrigeration systems are: activated carbon methanol (Vogel, 1986), activated carbon ammonia (Vasiliev et al., 1996), zeolite-water, calcium chloride ammonia and composite adsorbent ammonia (Iloeje et al., 1995). 


\subsubsection{Evaluation of Adsorption Refrigeration System for Residential Tri-generation}

Coupling an adsorption chiller with a CHP unit is quite challenging. This is because thermal energy demands during desorption are highly fluctuating throughout the cycle (Nurenz et al., 2010). A CHP unit designed for residential application is not able to handle such a fluctuating thermal demand. Moreover, adsorption chillers are heavy and bulky, and require regular maintenance, which makes it unsuitable for residential applications. The research group of Wang tested a silica gel water adsorption chiller for tri-generation purposes; details can be found in literature (Wang et al., 2005).

\subsection{Thermo-chemical Accumulator (TCA)}

In the absorption process, generally no chemical reaction occurs between the working fluid pair. The working pair only changes from one phase to another during the cycle. Salt-water absorption technology is a type of absorption system that produces a cooling effect using water as the refrigerant and salt solution as the absorber. The working principle of this system is based on a reversible salt-water reaction: exothermic absorption and endothermic desorption of vapour in salt (Nurenz et al., 2010).

The thermo-chemical accumulator (TCA) is an absorption system that uses salt-water as the working pair and also has internal thermal storage capacity (Borage et al., 2011). It can store thermal energy in the form of crystallized salt that can be used to produce a cooling effect even after long periods of storage. Olsson et al. (2000), first developed the TCA technology using a $\mathrm{LiCl}-\mathrm{H}_{2} \mathrm{O}$ working pair, which was patented in 2000. TCA is operated on a closed absorption cycle that uses the $\mathrm{LiCl}-\mathrm{H}_{2} \mathrm{O}$ working pair not only in liquid, vapour and solution phase, but also in solid phase. That is why this system is also termed as triple state absorption technology (Bales, 2000). Since 2000, a Swedish company named ClimateWell ${ }^{\mathrm{AB}}$ started working on building prototypes for a commercial product. After five generations of prototypes, the product is now available on the market under the brand name ClimateWell ${ }^{\circledR}$. In this residential tri-generation project, version-10 of the ClimateWell ${ }^{\circledR}$ chiller has been used. 


\subsubsection{Details about ClimateWell ${ }^{\circledR}$ Absorption Chiller}

The ClimateWell ${ }^{\circledR}$ chiller is a highly efficient air-conditioning unit that has the ability to store energy and deliver that energy for both heating and cooling. The patented triple state absorption technology makes ClimateWell ${ }^{\circledR}$ the first product to make efficient energy storage possible. ClimateWell ${ }^{\circledR}$ uses $\mathrm{LiCl}-\mathrm{H}_{2} \mathrm{O}$ as the working fluid in a triple state absorption condition. The working principle of the ClimateWell ${ }^{\circledR}$ chiller is the same as the thermo-chemical accumulator (TCA). The ClimateWell ${ }^{\circledR} 10$ chiller is the latest version that has solved many problems associated with the previous versions, such as: corrosion, leakage, noise and sticking of valves. Figure 3.8 shows a picture of the ClimateWell ${ }^{\circledR} 10$ chiller. The ClimateWell ${ }^{\circledR}$ chiller contains two barrels which allow one barrel to charge while the other one is discharging and vice-versa. This ensures an uninterrupted cooling supply. Each barrel comprises four chambers namely: condenser/evaporator, reactor (absorber/desorber), solution vessel and water vessel.

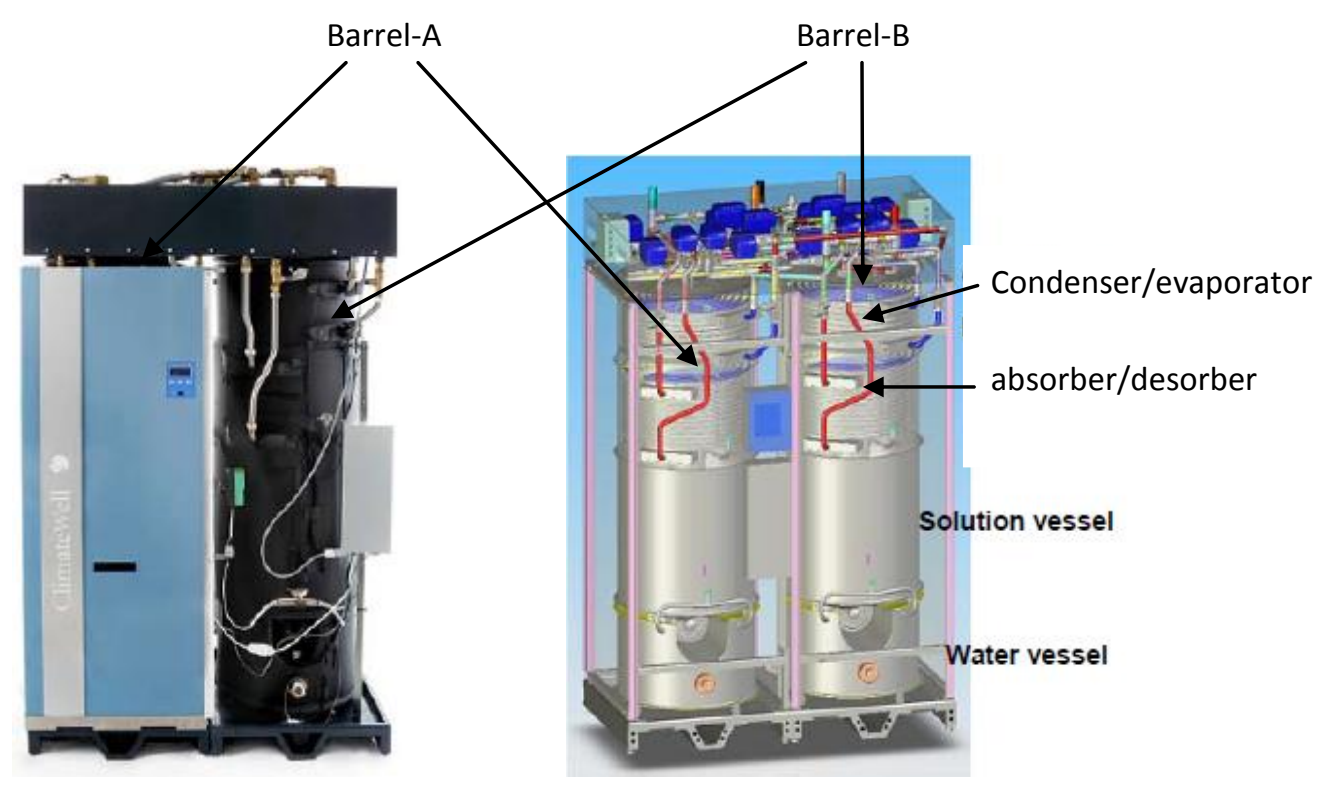

Figure 3.8 ClimateWell ${ }^{\circledR}$ chiller

Three main characteristics that make ClimateWell ${ }^{\circledR}$ different from a standard absorption chiller are as below (Nurenz et al., 2010):

- It has internal storage in each barrel. This machine is able to store chemical energy with high density that can subsequently be used for both cooling and heating purposes. 
- The energy storage density of the TCA is high in comparison to other thermal storage technologies. Storage density of $\mathrm{LiCl}-\mathrm{H}_{2} \mathrm{O}$ solution is approximately 300 $\mathrm{kWh} / \mathrm{m}^{3}$ and storage density of the whole unit is approximately $100-200 \mathrm{kWh} / \mathrm{m}^{3}$. This is 10-12 times higher than sensible water storage, which has an energy density of $10 \mathrm{kWh} / \mathrm{m}^{3}$.

- It works intermittently between two parallel barrels that allow one barrel to charge while the other one is in a discharge state.

- ClimateWell ${ }^{\circledR}$ is designed to be compatible with a low temperature energy source. This characteristic is critical for successful use in residential trigeneration.

\subsubsection{Working Principle of TCA/ ClimateWell ${ }^{\circledR}$ Chiller}

As shown in Figure 3.9, each barrel of the ClimateWell ${ }^{\circledR}$ chiller contains four different vessels where the actual processes takes place. Two of the vessels namely, the reactor (absorber/desorber) and the condenser/evaporator can be considered as active parts where the thermodynamic processes take place. The other two vessels are considered as water and salt solution reservoirs. Each barrel is a closed system operated under vacuum conditions and there are heat exchangers in the reactor and evaporator/condenser. The process occurs in two phases with a separate desorption (charge) phase followed by an absorption (discharge) phase. During the desorption (charge) phase, the condenser heat-exchanger is connected to the heat sink and the reactor heat-exchanger is connected to the heat source. During the absorption (discharge) phase, the evaporator heat-exchanger is connected to the building AHU and reactor heat-exchanger is connected to the heat sink. 


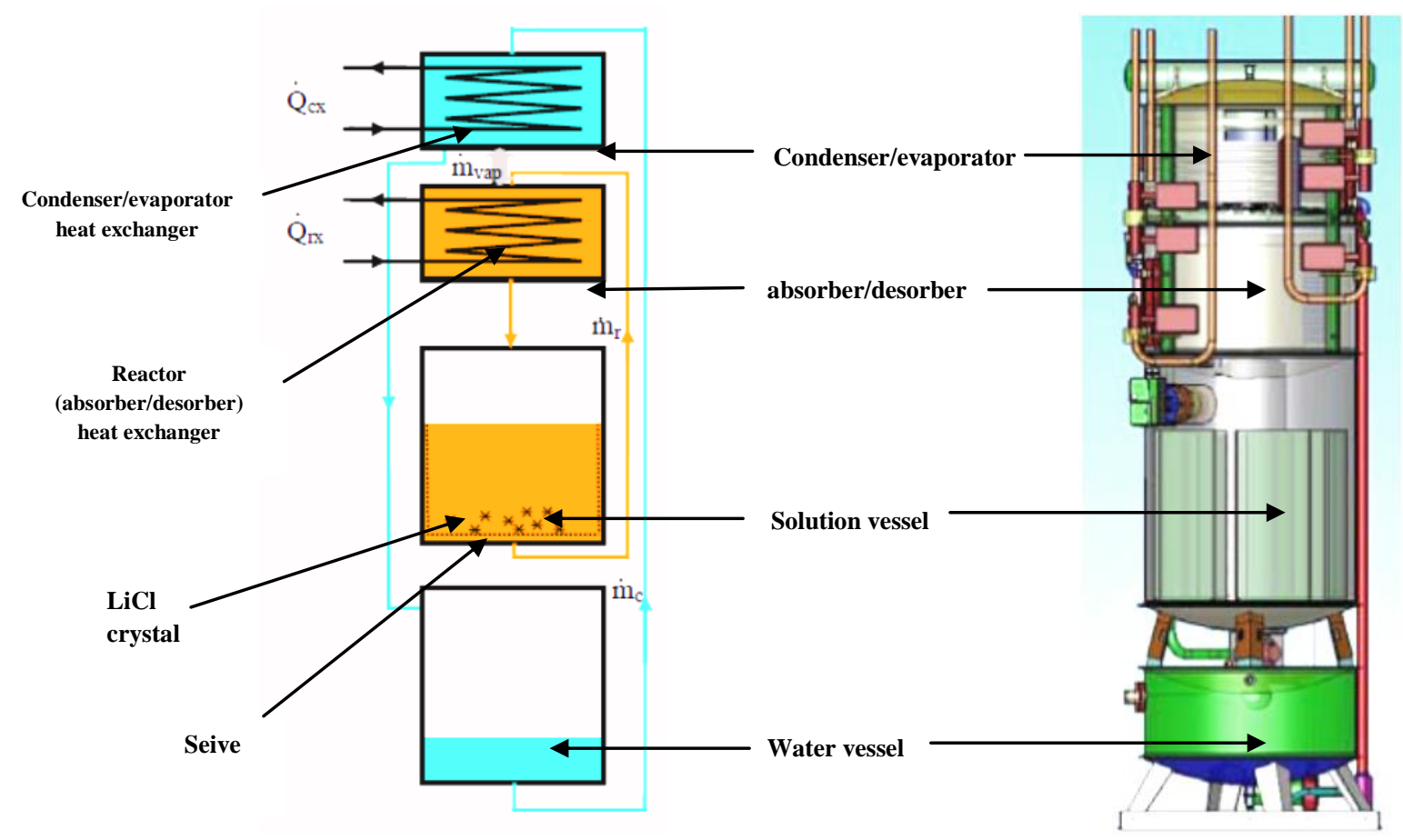

Figure 3.9 Schematic diagram of ClimateWell ${ }^{\circledR}$ barrels (Bales, 2000)

During the charging phase, unsaturated (diluted) $\mathrm{LiCl}$ solution $\left(\dot{m}_{r}\right)$ is pumped to the reactor vessel and spread over the reactor heat exchanger via the spreader arm to increase the heat transfer area. The external heat source heats up the solution and the desorption process starts. During the desorption process, water is evaporated and is separated from the LiCl solution. The separated water vapor enters the condenser where it is condensed into liquid. The condenser heat-exchanger is connected to an external heat sink that removes the heat rejected by the water vapor. Condensed liquid water flows under gravity to the water vessel which is at the bottom of each barrel. During the charging process as the desorption of $\mathrm{LiCl}$ solution continues, the $\mathrm{LiCl}$ solution gets closer and closer to saturation and starts forming solid crystals. The solid crystals fall under gravity to the bottom of the solution vessel. Not all the $\mathrm{LiCl}$ is converted to solid crystal. So, at the end of the charging process, there is slurry of $\mathrm{LiCl}$ together with $\mathrm{LiCl}$ crystals in the solution vessel.

During the discharge phase, the evaporator heat-exchanger is connected to the building/space to be cooled and the reactor heat-exchanger is connected to the heat-sink. A mass of water $\left(\dot{m}_{c}\right)$ and a mass of $\mathrm{LiCl}$ solution $\left(\dot{m}_{r}\right)$ (saturated $\mathrm{LiCl}$ slurry) is pumped from the water vessel and 
solution vessel, respectively, and is spread to the evaporator heat-exchanger and reactor heatexchanger, respectively, via the spreader arm. In the evaporator, water is vaporized and the necessary energy is taken from the space to be cooled. Water vapor $\left(m_{\text {evap }}\right)$ enters to the absorber where it is absorbed by the saturated $\mathrm{LiCl}$ slurry. As the absorption process continues, $\mathrm{LiCl}$ becomes unsaturated. This unsaturated $\mathrm{LiCl}$ solution then falls to the solution vessel by gravity flow and by dissolving the crystals, becomes saturated again. This saturated $\mathrm{LiCl}$ is then pumped to the absorber again and thus, the absorption process continues until all the $\mathrm{LiCl}$ solution is unsaturated. Condensation energy released by the water vapor during the absorption process is rejected to the external heat sink. At the end of the absorption process, the solution vessel becomes full with unsaturated $\mathrm{LiCl}$ solution and the water vessel becomes almost empty.

In traditional $\mathrm{LiBr}-\mathrm{H}_{2} \mathrm{O}$ machines, formation of crystal is unwanted as it causes the destruction of the machine. Also, in a traditional absorption machine, the working fluid remains in two phases: liquid and vapor. The traditional absorption cycle is a continuous process; so the heat source should be available all the time and no cooling effect is available without the availability of heat. In contrast, the solid crystal formation in the TCA provides the machine energy storage capacity that can be used during the period when a heat source is not available. The thermodynamic cycle in the TCA is not continuous; it works in batch mode with a separate charging phase (desorption) followed by a discharge (absorption) phase. During the charging phase, the TCA stores energy and in the discharge phase provides cooling effect utilizing the stored energy. In the TCA, the working fluid exists in three phases: liquid, vapor and solid crystal; for this reason, this technology is also termed a triple-state absorption technology.

\subsubsection{Physical Dimensions}

The ClimateWell $^{\circledR} 20$ is a very recent version of the ClimateWell ${ }^{\circledR}$ chiller. It is operated in the same working principle as ClimateWell ${ }^{\circledR} 10$. The main difference between the 10 and 20 version is in terms of capacity. Version 10 machines have a cooling capacity of $50 \mathrm{kWh}$, whereas version 20 machines have slightly higher cooling capacity of $56 \mathrm{kWh}$. This is possible because in version 20 machines, the volume of the salt-water is a bit higher than version 10 machines. Figure 3.10 shows physical dimensions of ClimateWell ${ }^{\circledR}$ chiller and Table 3.1 shows technical specifications of ClimateWell ${ }^{\circledR} 10$ and 20 chillers. 

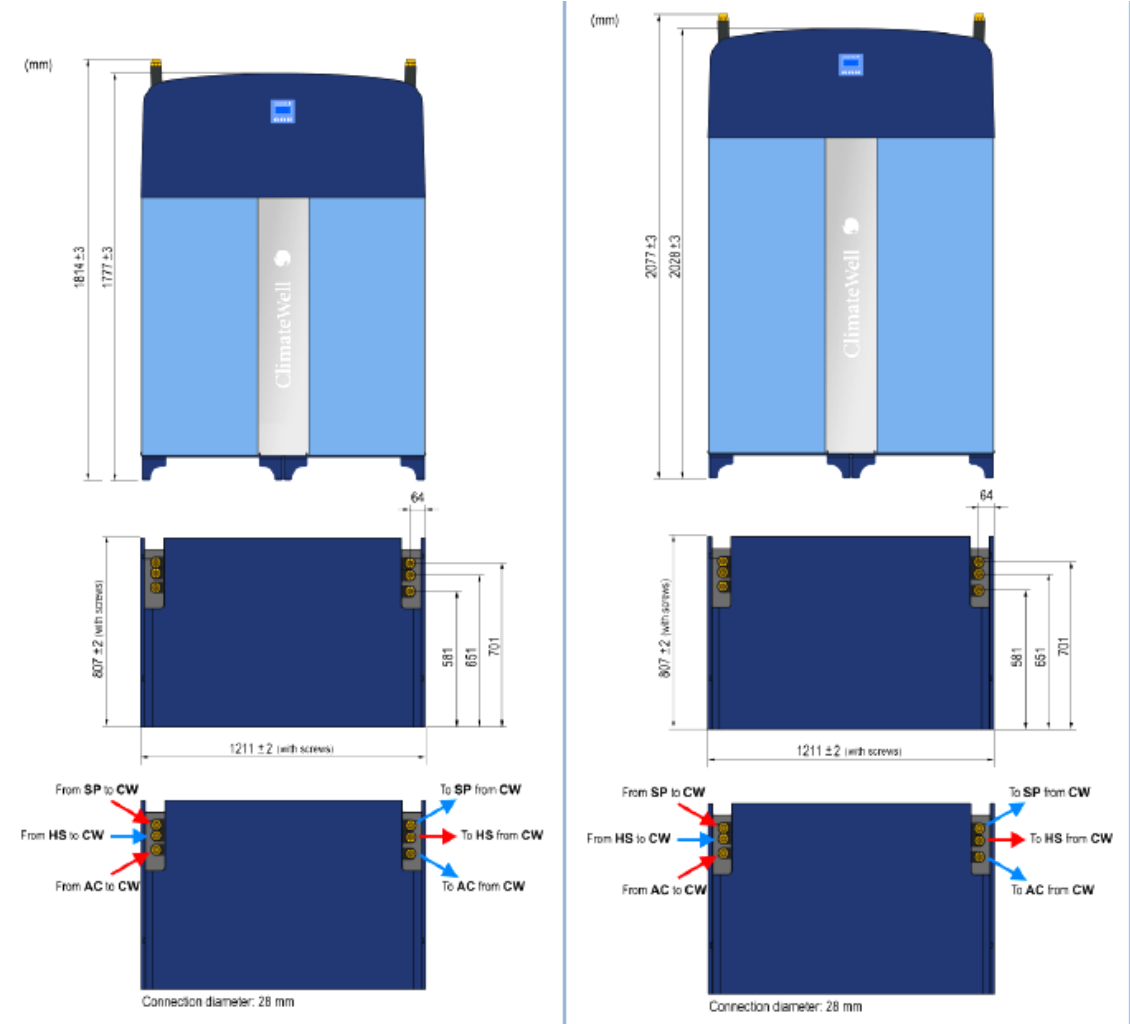

Figure 3.10 Physical dimension of the ClimateWell ${ }^{\circledR}$ unit (Olofsson, 2009)

Table 3.1 Technical specifications of ClimateWell ${ }^{\circledR}$ chiller (Olofsson, 2009)

\begin{tabular}{|c|c|c|c|}
\hline & & ClimateWell $^{\mathrm{TM}} 10$ & ClimateWell $^{\text {TM }} 20$ \\
\hline Nominal Power & Cooling & See Power Curves & See Power Curves \\
\hline Average Power Consumption & Electrical & $18 W$ & $18 W$ \\
\hline COP & (Thermal) & $\begin{array}{l}\text { Triple state absorption } \\
\text { process COP } 0.68 \text {. } \\
\text { Implemented COP will } \\
\text { depend on installation } \\
\text { characteristics. }\end{array}$ & $\begin{array}{l}\text { Triple state absorption } \\
\text { process COP } 0.68 \text {. } \\
\text { Implemented COP will } \\
\text { depend on installation } \\
\text { characteristics, typically } 0,52 \text { - } \\
0,57 \text {. }\end{array}$ \\
\hline $\begin{array}{l}\text { The Maximum Temperature to } \\
\text { ClimateWell }\end{array}$ & From Heat Source & $120^{\circ} \mathrm{C}$ & $120^{\circ} \mathrm{C}$ \\
\hline Maximum Pressure & From Heat Source & 10 bar & 10 bar \\
\hline \multirow{3}{*}{ Pressure Drop } & Heat Source Circuit & $15 \mathrm{kPa}$ at $15 / / \mathrm{min}$ & $30 \mathrm{kPa}$ at $251 / \mathrm{min}$ \\
\hline & Heat Rejection Circuit & $20 \mathrm{kPa}$ at $30 / \mathrm{min}$ & $38 \mathrm{kPa}$ at $50 / / \mathrm{min}$ \\
\hline & Distribution Circuit & $20 \mathrm{kPa}$ at $15 / / \mathrm{min}$ & $45 \mathrm{kPa}$ at $251 / \mathrm{min}$ \\
\hline Energy Storage Capacity & Cooling & $50 \mathrm{kWh}$ & $56 \mathrm{kWh}$ \\
\hline Dimensions & $\mathrm{H} \times W \times \mathrm{D}$ & $1685 \times 1211 \times 807 \mathrm{~mm}$ & $2038 \times 1211 \times 807 \mathrm{~mm}$ \\
\hline Weight & & $826 \mathrm{~kg}$ & $990 \mathrm{~kg}$ \\
\hline Fluid Volume & Operational & 491 & 74,51 \\
\hline Salt Solution & Lithium chloride & $\mathrm{LiCl}$ & $\mathrm{LiCl}$ \\
\hline
\end{tabular}




\subsubsection{External Connections}

The ClimateWell ${ }^{\circledR}$ unit needs to be connected with three external circuits, namely: the heat source circuit, the distribution circuit and the heat rejection circuit. For a residential trigeneration system, a gas fired CHP can be used as the heat source for the ClimateWell ${ }^{\circledR}$ unit. Figure 3.11 shows the connection diagram and Table 3.2 shows the technical specifications of the three external circuits.

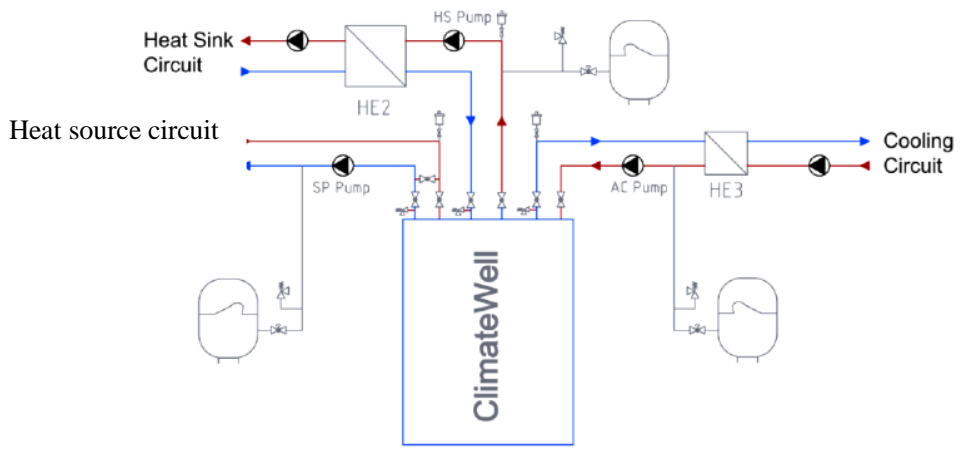

Figure 3.11 Connection diagram of ClimateWell ${ }^{\circledR}$ chiller to external circuits (Olofsson, 2009)

Table 3.2 Technical specifications of the three external circuits (Olofsson, 2009)

\begin{tabular}{|c|c|c|c|c|}
\hline & & & ClimateWell ${ }^{\mathrm{TM}} 10$ & ClimateWell ${ }^{\mathrm{TM}} 20$ \\
\hline \multirow[t]{7}{*}{ Heat Source Circuit } & \multicolumn{2}{|l|}{ Flow } & $15-20 \mathrm{l} / \mathrm{min}$ & $25-30 \mathrm{~V} / \mathrm{min}$ \\
\hline & \multicolumn{2}{|l|}{ Typical Power Range } & $10-15 \mathrm{~kW}$ & $15-20 \mathrm{~kW}$ \\
\hline & \multirow{2}{*}{ Operational Temperature } & Out & $75^{\circ} \mathrm{C}-100^{\circ} \mathrm{C}$ & $75^{\circ} \mathrm{C}-100^{\circ} \mathrm{C}$ \\
\hline & & In & $85^{\circ} \mathrm{C}-110^{\circ} \mathrm{C}$ & $85^{\circ} \mathrm{C}-110^{\circ} \mathrm{C}$ \\
\hline & \multicolumn{2}{|l|}{ Operational Pressure } & 3 bars & 3 bars \\
\hline & \multicolumn{2}{|l|}{ Maximum Pressures } & 6 bars & 6 bars \\
\hline & \multicolumn{2}{|l|}{ Type of Fluid } & $\begin{array}{l}\text { Propylene Glycol } 1,2 \mathrm{~L} \\
\geq 15 \% \text { concentration }\end{array}$ & $\begin{array}{l}\text { Propylene Glycol } 1,2 L \geq \\
15 \% \text { concentration }\end{array}$ \\
\hline \multirow[t]{5}{*}{ Distribution Circuit } & \multicolumn{2}{|l|}{ Flow } & $15-20 \mathrm{l} / \mathrm{min}$ & $25-30 \mathrm{Vmin}$ \\
\hline & \multicolumn{2}{|l|}{ Nominal Power } & See Power Curves & See Power Curves \\
\hline & \multirow{2}{*}{ Operational Temperature } & Out & $10^{\circ} \mathrm{C}-16^{\circ} \mathrm{C}$ & $10^{\circ} \mathrm{C}-16^{\circ} \mathrm{C}$ \\
\hline & & In & $15^{\circ} \mathrm{C}-21^{\circ} \mathrm{C}$ & $15^{\circ} \mathrm{C}-21^{\circ} \mathrm{C}$ \\
\hline & \multicolumn{2}{|l|}{ Type of Fluid } & $\begin{array}{l}\text { Propylene Glycol } 1,2 \mathrm{~L} \\
\geq 15 \% \text { concentration }\end{array}$ & $\begin{array}{l}\text { Propylene Glycol } 1,2 \mathrm{~L} \geq 15 \\
\% \text { concentration }\end{array}$ \\
\hline \multirow[t]{5}{*}{ Heat Rejection Circuit } & \multicolumn{2}{|l|}{ Flow } & $30-40 \mathrm{Vmin}$ & $50-60 \mathrm{~V} / \mathrm{min}$ \\
\hline & \multicolumn{2}{|l|}{ Nominal Power } & See Power Curves & See Power Curves \\
\hline & \multirow{2}{*}{ Operational Temperature } & Out & $30^{\circ} \mathrm{C}$ to $45^{\circ} \mathrm{C}$ & $30^{\circ} \mathrm{C}$ to $45^{\circ} \mathrm{C}$ \\
\hline & & In & $<30^{\circ} \mathrm{C}$ & $<30^{\circ} \mathrm{C}$ \\
\hline & \multicolumn{2}{|l|}{ Type of Fluid } & $\begin{array}{l}\text { Propylene Glycol } 1,2 \mathrm{~L} \\
\geq 15 \% \text { concentration }\end{array}$ & $\begin{array}{l}\text { Propylene Glycol } 1,2 \mathrm{~L} \geq 15 \\
\% \text { concentration }\end{array}$ \\
\hline
\end{tabular}




\subsubsection{Heat Source Circuit}

The ClimateWell ${ }^{\circledR}$ unit receives the required charging energy from an external thermal source. The external source can be solar thermal, district heating or waste heat from a CHP unit. In this residential tri-generation project, a gas fired CHP unit with a thermal capacity of $12 \mathrm{~kW}$ is used as the heat source. During charging, the heat source temperature should be at least $50^{\circ} \mathrm{C}$ above the heat sink temperature. The charging power and time depends on the temperature and flow of the heat source. In most cases, when solar thermal is used as the heat source, it is recommended to install a small gas fired boiler or simple electric heater as a backup power source during prolonged cold/cloudy periods. The charging performance of the ClimateWell ${ }^{\circledR}$ chiller is shown in Figure 3.12. In Figure 3.12, 'Ths' stands for heat rejection temperature. It is observed from the Figure 3.12 that the charging performance (power) increases for lower heat rejection temperature. This means that the unit can be charged less rapidly when the heat rejection temperature is high. As will be discussed further in Chapter-5 and Chapter-6, this is a critical factor in the performance of the unit for residential tri-generation applications.

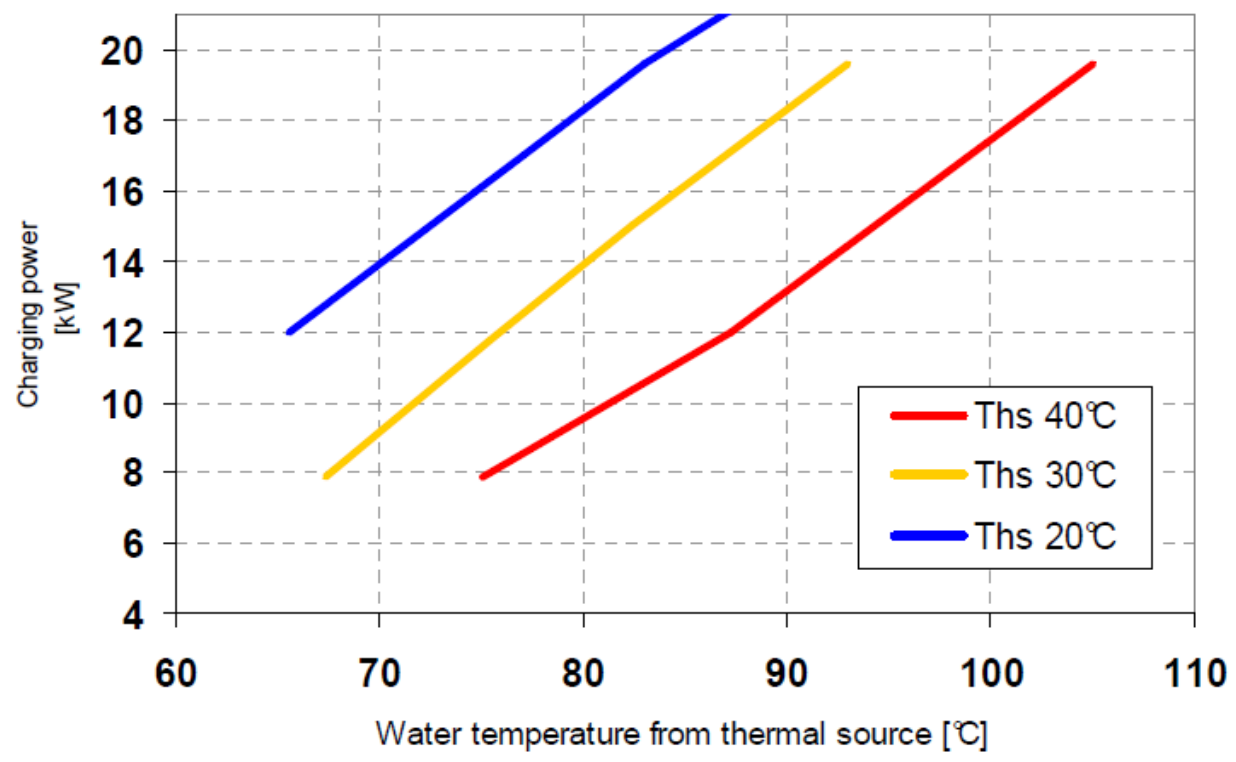

Figure 3.12 Charging performance of the ClimateWell ${ }^{\circledR}$ chiller (Olofsson, 2009) 


\subsubsection{Distribution Circuit}

The distribution circuit of the ClimateWell ${ }^{\circledR}$ unit can be connected to the radiant floor, fan coil unit, chilled beam, ceiling system or AHU. The ClimateWell ${ }^{\circledR}$ chiller works more effectively for a higher temperature drop in the distribution circuit. Thus it is ideal for radiant floor/ceiling applications, where temperatures up to $18^{\circ} \mathrm{C}$ can be used. In this residential tri-generation project, the distribution circuit of the ClimateWell ${ }^{\circledR}$ chiller is connected to the building AHU. The cooling performance of the ClimateWell ${ }^{\circledR}$ chiller is shown in Figure 3.13. It is observed from Figure 3.13 that cooling performance (power) increases for lower heat rejection temperature. Again as will be discussed in Chapter-5 and Chapter-6, this is a critical performance issue for residential tri-generation, rejecting heat on the hottest day of summer.

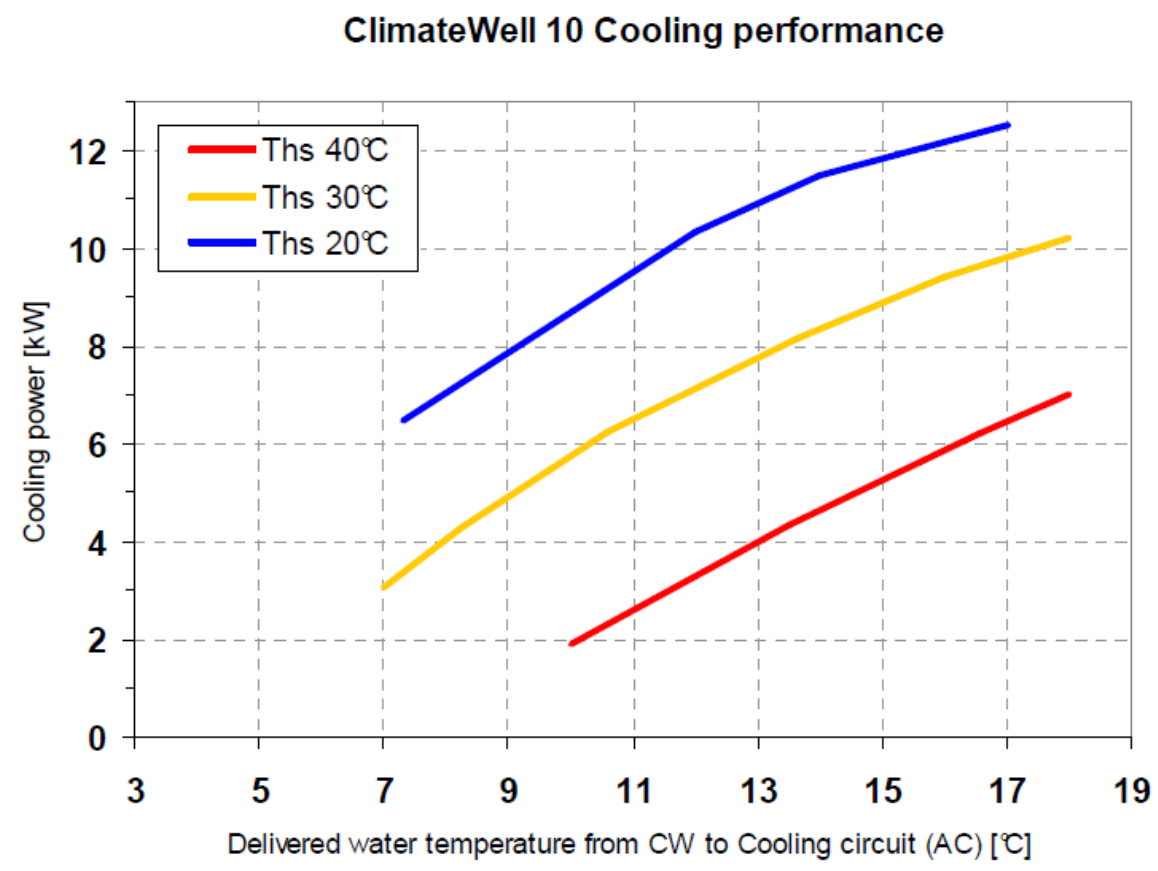

Figure 3.13 Cooling performance of the ClimateWell ${ }^{\circledR}$ chiller (Olofsson, 2009)

\subsubsection{Heat Rejection Circuit}

The thermal efficiency of the ClimateWell ${ }^{\circledR}$ unit depends on an efficient heat rejection system. The cooling power of the ClimateWell ${ }^{\circledR}$ unit improves for lower heat rejection temperature. The temperature from the heat sink is dependent on the ambient conditions. So, it is important to 
balance the cooling power and the heat rejection temperature. During the charging cycle, the ClimateWell ${ }^{\circledR}$ rejects about $76 \%$ of the supplied energy; therefore the dimensioning power of the heat sink at the flow rate of $30 \mathrm{1} / \mathrm{min}$ is $20 \mathrm{~kW}$. Possible heat rejection options for ClimateWell ${ }^{\circledR}$ chiller are listed as below:

- Outdoor swimming pool. By heating pool water, energy can be used twice.

- Pre-heating of domestic water. This is mostly recommended for hotels and hospitals where there is substantial requirement of hot water for showers, kitchen, laundry etc.

- Evaporative cooling towers are recommended when more than one ClimateWell ${ }^{\circledR}$ chiller is installed.

- An air cooled heat-exchanger is most suitable for a single family house.

- Geothermal circuits, such as boreholes or earth loops are another suitable option for heat rejection. But this option is associated with large initial investment.

Heat rejection is one of the major issues related to the ClimateWell ${ }^{\circledR}$ chiller, as the performance is highly dependent on efficient heat rejection. The ClimateWell ${ }^{\circledR}$ chiller rejects a large quantity of low grade heat (usually temperatures less than $50^{\circ} \mathrm{C}$ ). Utilizing the rejected heat wisely can increase the overall efficiency of the tri-generation system. Details about the heat rejection issues are discussed in Chapter-5 of this thesis.

\subsubsection{Valves and Control System}

Each ClimateWell ${ }^{\circledR}$ chiller contains a Switching \& Controller unit that is connected with both barrels as shown in Figure 3.14. It controls charging and discharge processes of the two barrels by operating different valves and pumps. It continuously receives data from different sensors of each barrel and based on that sends an output signal to open/close different valves and pumps. 


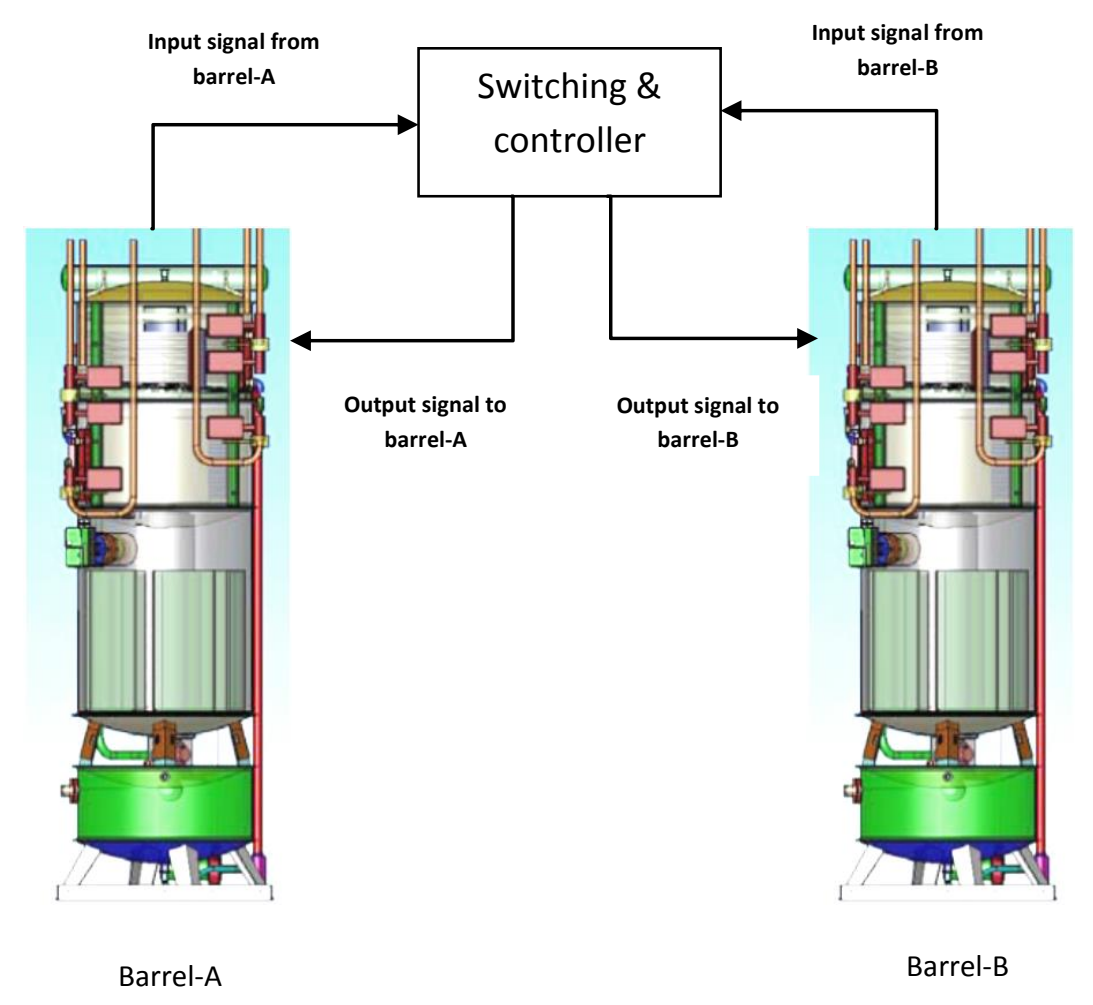

Figure 3.14 ClimateWell ${ }^{\circledR}$ barrels connected with the Switching \& Controller unit (Bales, 2000)

\subsubsection{Valve Arrangement of ClimateWell ${ }^{\circledR}$ chillers}

Each ClimateWell $^{\circledR}$ barrel is mounted with five different valves that control flow through the condenser/evaporator heat-exchanger and the generator/absorber heat-exchanger. Different combinations of valves connect the condenser/evaporator and generator/absorber with different external circuits. Figure 3.15 and Figure 3.16 shows valve arrangement of the ClimateWell ${ }^{\circledR}$ chiller and a schematic diagram of the valve arrangement respectively. 


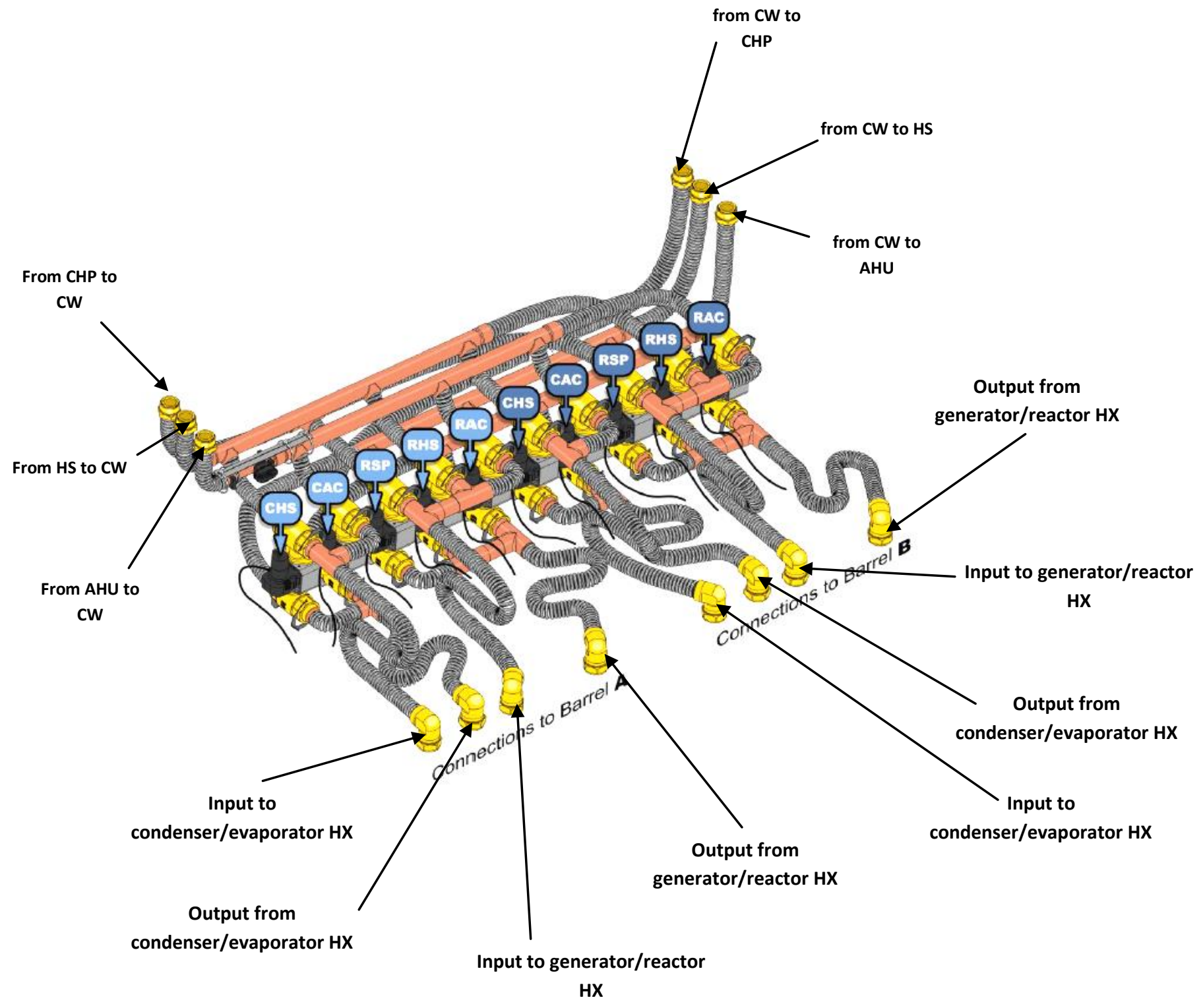

Figure 3.15 Valve arrangements of ClimateWell ${ }^{\circledR}$ chillers 


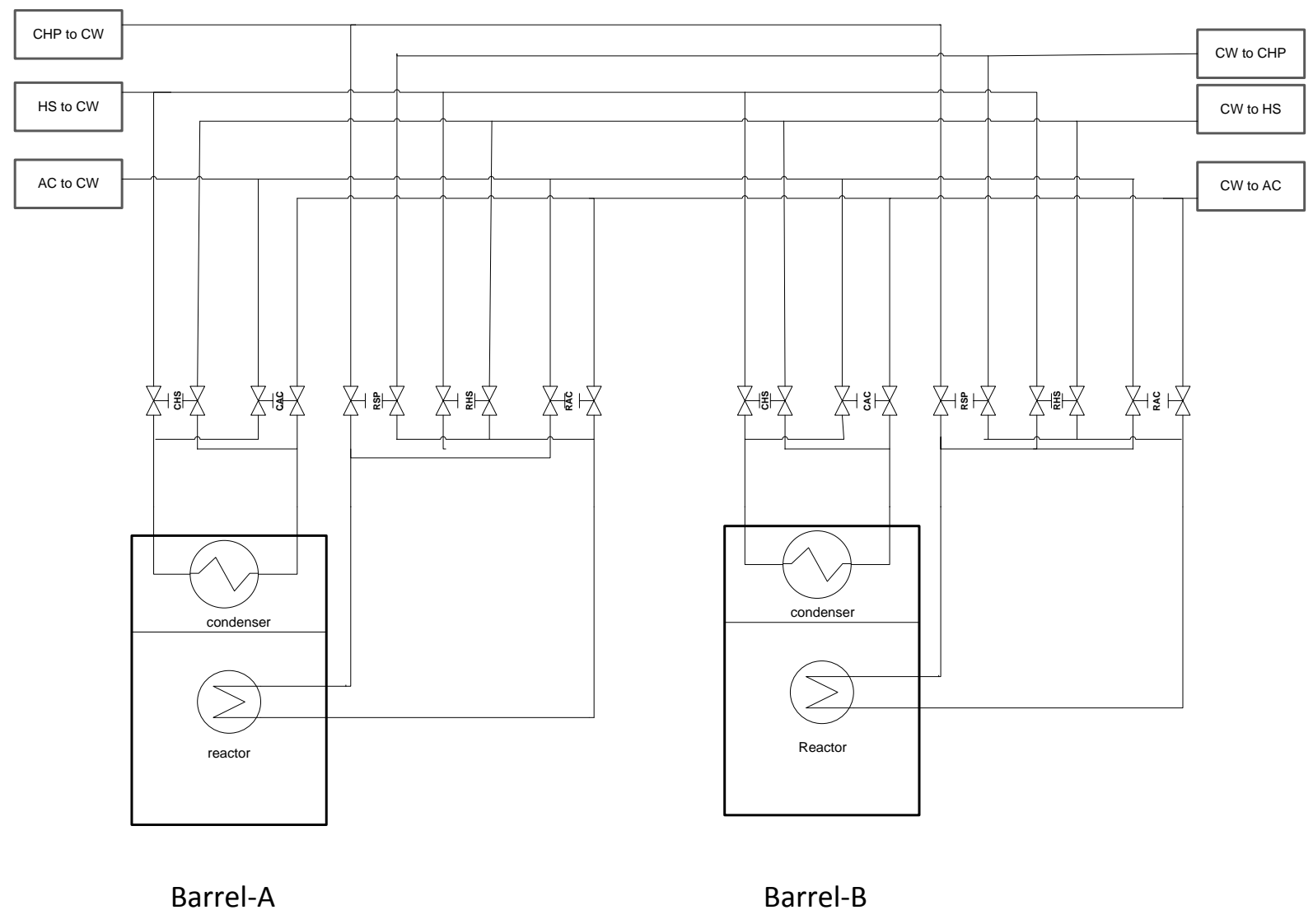

Figure 3.16 Schematic diagram of valve arrangement of ClimateWell ${ }^{\circledR}$ chillers

During the charging cycle, the generator heat-exchanger is connected with the heat source and condenser heat-exchanger is connected to the heat sink. During the discharge cycle, the evaporator heat-exchanger is connected to the AHU and, space to be cooled and absorber heatexchanger is connected to the heat sink. The Switching \& Controller unit sends signals to respective vales and connects the heat exchangers with the source/sink/AHU. The Switching \& Controller unit receives signals from sensors associated with each barrels and based on that determines the charge level/ state of charge (SOC). Based on the SOC, the Controller unit decides which unit to charge/discharge and send signals to open/close respective valves and pumps. Figure 3.17 and Figure 3.18 shows the states of valves (SOV) for Barrel-A charging and Barrel-B charging respectively. By default, when a barrel is charging, the other barrel is discharging. 


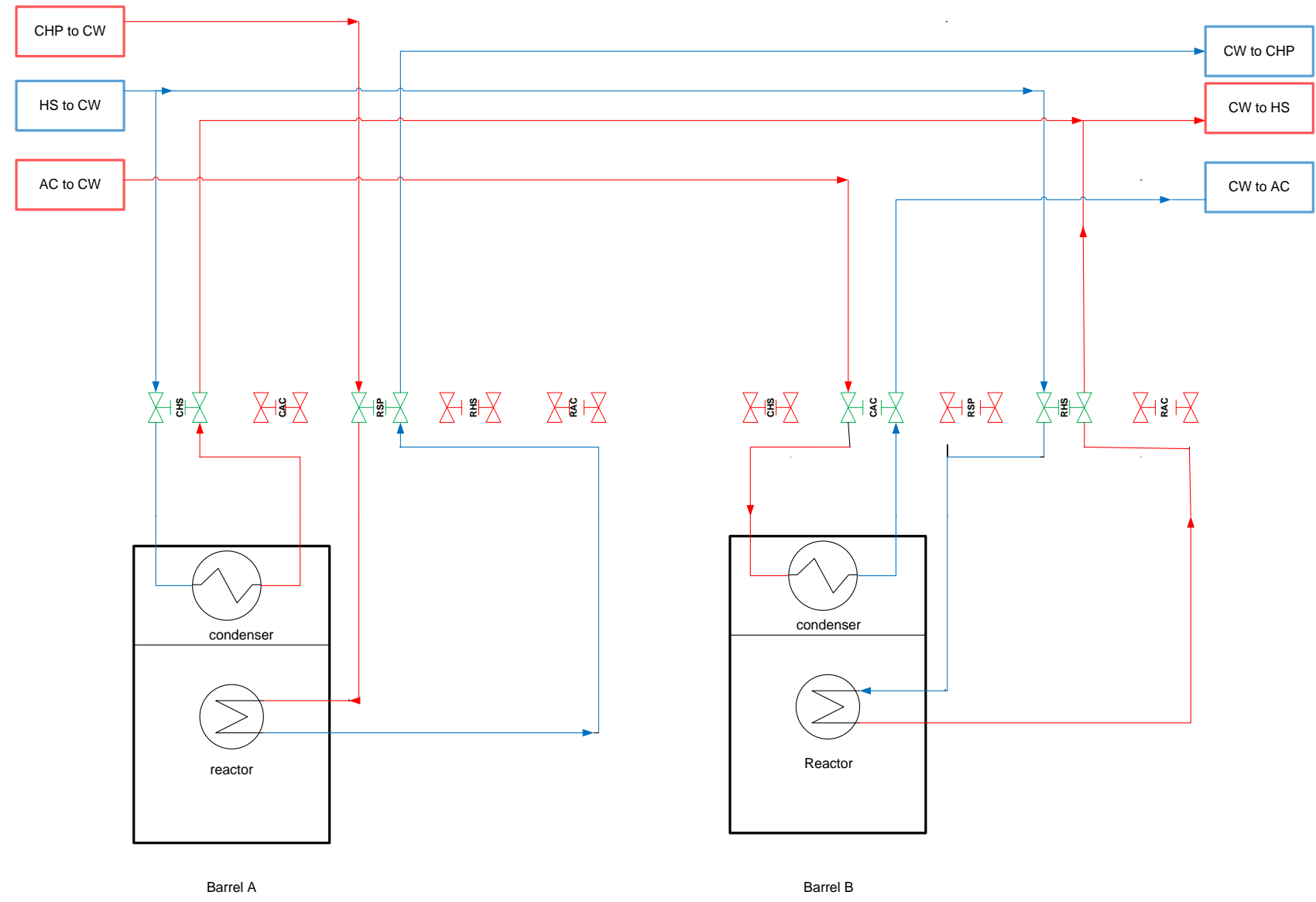

Figure 3.17 Valve schematic for Barrel-A charging and Barrel-B discharging (valves that are open are marked green and red mark indicates that the valve is closed. Red line indicates flow of hot fluid and blue line indicates flow of cold fluid) 


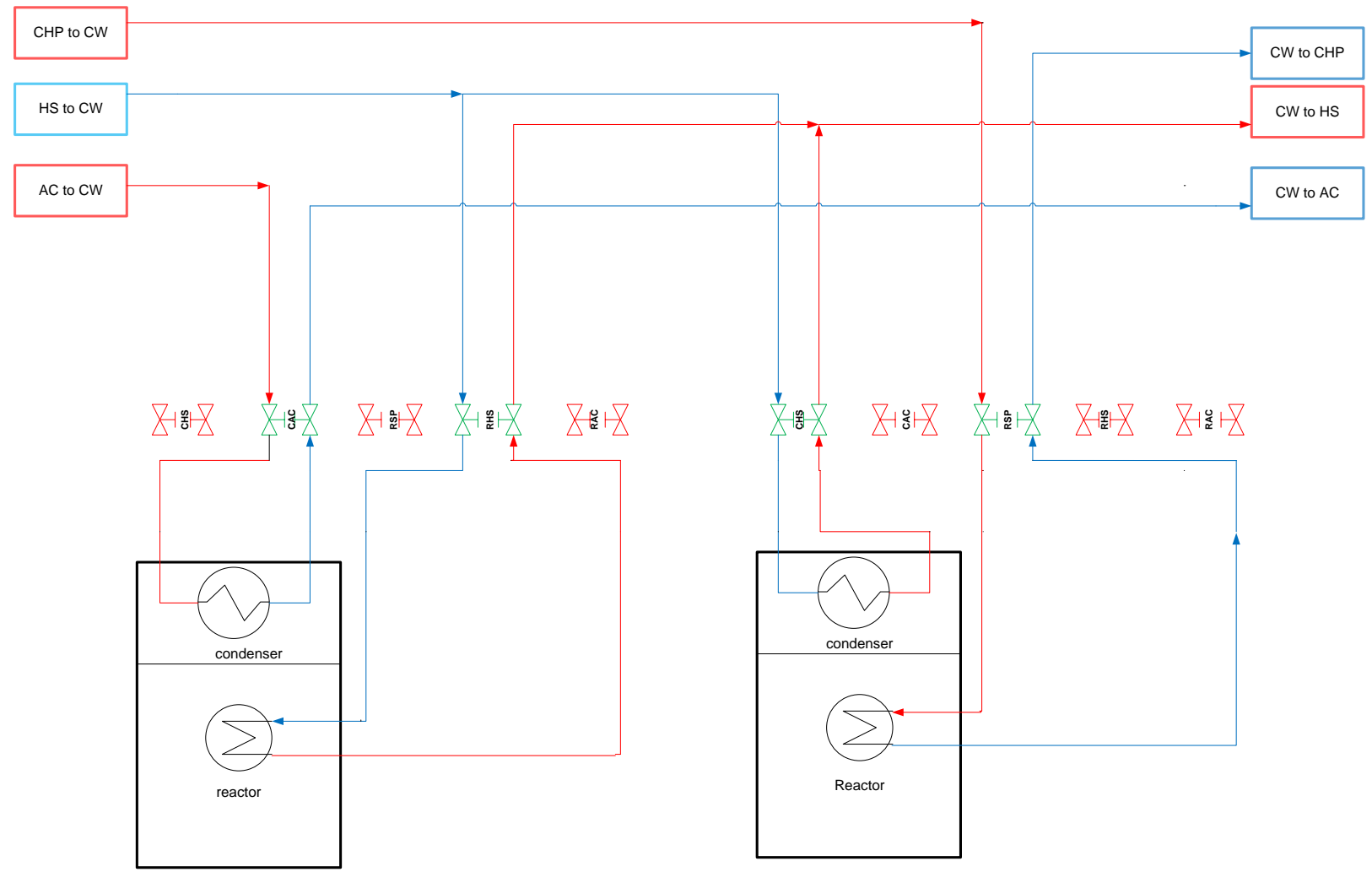

Figure 3.18 Valve schematic for Barrel-B charging and Barrel-A discharging (valves that are open are marked green and red mark indicates that the valve is closed. Red line indicates flow of hot fluid and blue line indicates flow of cold fluid)

\subsection{Safety Issues related to ClimateWell ${ }^{\circledR}$ Chiller:}

The LiCl- $\mathrm{H}_{2} \mathrm{O}$ salt solution used in the $\mathrm{Climatewell}^{\circledR}$ chiller is non-toxic and non-lethal in nature. However, $\mathrm{LiCl}$ is highly corrosive in the presence of oxygen. Each ClimateWell unit is properly sealed by the manufacturer so that air cannot enter. The manufacturer claims that the $\mathrm{LiCl}$ salt and the sheet-metal used in ClimateWell ${ }^{\circledR}$ chiller is recyclable and the typical life span of each machine is about 15 years (Olofsson, 2009). 


\section{Summary}

Combined heat and power (CHP) units designed for residential application have supply temperatures ranging from $80^{\circ} \mathrm{C}$ to $100^{\circ} \mathrm{C}$. So, it is important to find a suitable TDC that is compatible with CHPs. TCA technology is a suitable candidate as it can be powered by low temperature $\left(<80^{\circ} \mathrm{C}\right)$ heat sources and consumes very little electricity. Moreover the energy storage capacity of TCA, allows more flexibility in terms of charging and discharging. ClimateWell ${ }^{\circledR}$ chillers are the only commercially available product on the market that use TCA technology. In Canada, this project is the first of its kind using the ClimateWell ${ }^{\circledR}$ technology for residential tri-generation purposes. Utilizing the rejected heat from the ClimateWell ${ }^{\circledR}$ chiller wisely can reduce the overall energy consumption of a house. 


\section{Chapter-4}

\section{Methodology}

This chapter explains in detail about the experimental setup used in this residential tri-generation project. A DAQ system for measuring the performance of the tri-generation system, different types of sensors, pumps and other equipment used are also described. Equations used for energy consumption, generation and efficiency calculation are also stated in this chapter.

\subsection{Experimental Location}

In Ontario, the Toronto and Regional Conservation Authority (TRCA) works to promote green buildings. Along with the Building Industry and Land Development (BILD) Association, they have implemented the "Archetype Sustainable House (ASH)" project at the living city campus at the Kortright center in Vaughan, Ontario. For the experimental work of this project, the ASH was employed. The ASH is composed of two (almost) identical semi-detached twin houses namely: House-A and House-B. Figure 4.1 shows the south view of the ASH with House-A on the left and House-B on the right. The two houses are equipped with different mechanical systems and a comprehensive monitoring system. House-A demonstrates energy efficiency technologies and practices that are currently available on the market, while House-B is the showcase for advanced technologies that can be used in residential houses in the near future. Both houses are R2000 and LEED Platinum certified (Dembo et al., 2010). No occupants live in the houses and they houses are open for public visits.

The presented residential tri-generation system based on the ClimateWell ${ }^{\circledR}$ technology is a new concept, so House-B has been chosen for experimental work. House-B is a three storey house with floor area $317 \mathrm{~m}^{2}$ and $46.4 \mathrm{~m}^{2}$ triple glazed window areas (Barua, 2010). House-B is a wellinsulated house and "Bloor Door Test" shows air tightness of 1.214 ACH at 50Pa (Dembo et al., 2010). When the outdoor and indoor temperatures are $31^{\circ} \mathrm{C}$ and $26^{\circ} \mathrm{C}$, the cooling load of HouseB is $6.18 \mathrm{~kW}$ (Barua et al., 2010). A comparison of HVAC systems among different housing standards is shown in Table 4.1. Table 4.2 and Table 4.3 shows basic design and structural features of House-B. To measure the performance of House-B and its mechanical systems, it is instrumented with over 300 sensors of different kinds. National Instrument's LabView software 
and data acquisition (DAQ) hardware have been used to capture sensor signals and all data is stored in the SQL database (Zhang et al., 2011).

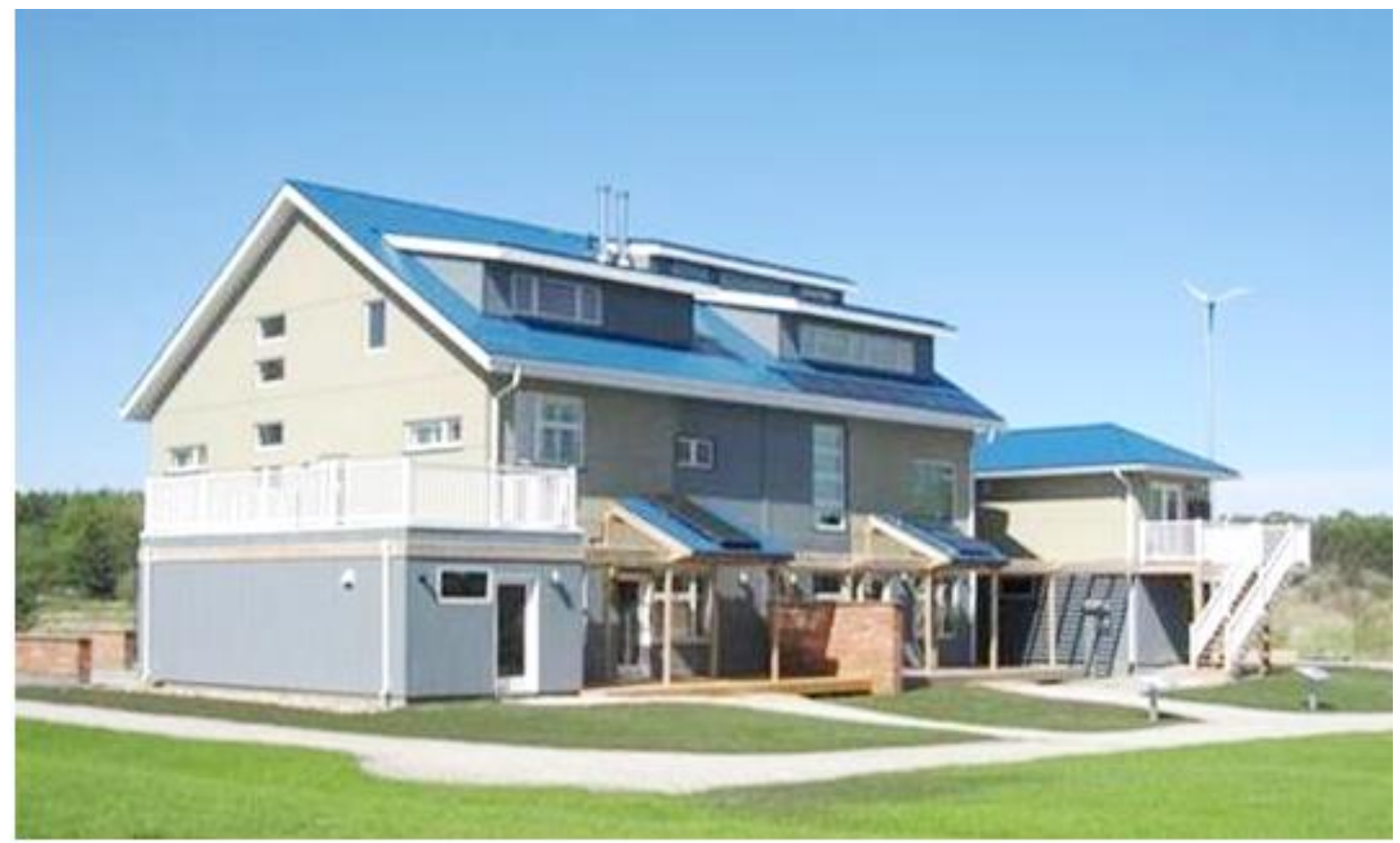

Figure 4.1 South view of the ASH (Barua, 2010)

Table 4.1 Comparison of HVAC systems among different housing standards

\begin{tabular}{|l|c|c|c|}
\hline \multicolumn{1}{|c|}{ Equipment } & $\begin{array}{c}\text { Traditional } \\
\text { House }\end{array}$ & $\begin{array}{c}\text { R-2000 } \\
\text { Standard }\end{array}$ & $\begin{array}{c}\text { ASH of } \\
\text { TRCA }\end{array}$ \\
\hline Solar collector for hot water generation & No & No & Yes \\
\hline Co-generation system for power and hot water generation & No & No & Yes \\
\hline Solar wall to supply hot air to the zone & No & No & Yes \\
\hline PV cells for power generation & No & No & Yes \\
\hline Wind turbine for power generation & No & No & Yes \\
\hline GSHP for space heating and cooling & No & No & Yes \\
\hline HRV/ERV for recovery of heat from exhaust air & No & Yes & Yes \\
\hline Drain water heat recovery & No & No & Yes \\
\hline Radiant floor heating & No & Yes & Yes \\
\hline
\end{tabular}


Table 4.2 Basic design features of House-B (Barua, 2010)

\begin{tabular}{|c|c|c|}
\hline Features & House-B & In-law suite of House-B \\
\hline Orientation & South facing & South facing \\
\hline Stories & 3 & garage in ground floor \\
\hline Floor & $232 \mathrm{~m}^{2} /\left(25^{\prime \prime} \times 40^{\prime \prime}\right) / 2500 \mathrm{ft}^{2}$ & $32 \mathrm{~m}^{2} /\left(28^{\prime \prime} \times 12.5^{\prime \prime}\right) / 350 \mathrm{ft}^{2}$ \\
\hline Natural infiltration & $0.06 \mathrm{ACH}$ & $0.06 \mathrm{ACH}$ \\
\hline Winter design condition & $\begin{array}{c}\text { Outdoor temp.: }-22^{\circ} \mathrm{C} /-7.6^{\circ} \mathrm{F} \\
\text { Indoor temp.: } 22^{\circ} \mathrm{C} / 71.6^{\circ} \mathrm{F}\end{array}$ & $\begin{array}{c}\text { Outdoor temp.: }-22^{\circ} \mathrm{C} /-7.6^{\circ} \mathrm{F} \\
\text { Indoor temp.: } 22^{\circ} \mathrm{C} / 71.6^{\circ} \mathrm{F}\end{array}$ \\
\hline $\begin{array}{c}\text { Summer design } \\
\text { condition }\end{array}$ & $\begin{array}{c}\text { Outdoor dry bulb: } 31^{\circ} \mathrm{C} / 87.8^{\circ} \mathrm{F} \\
\text { Outdoor wet bulb: } 24^{\circ} \mathrm{C} / 75.2^{\circ} \mathrm{F} \\
\text { Indoor temp: } 26^{\circ} \mathrm{C} / 78.8^{\circ} \mathrm{F}\end{array}$ & $\begin{array}{c}\text { Outdoor dry bulb: } 31^{\circ} \mathrm{C} / 87.8^{\circ} \mathrm{F} \\
\text { Outdoor wet bulb: } 24^{\circ} \mathrm{C} / 75.2^{\circ} \mathrm{F} \\
\text { Indoor temp: } 26^{\circ} \mathrm{C} / 78.8^{\circ} \mathrm{F}\end{array}$ \\
\hline Heating load & $7.94 \mathrm{~kW}$ & $1.64 \mathrm{~kW}$ \\
\hline Cooling load & $6.18 \mathrm{~kW}$ & $1.61 \mathrm{~kW}$ \\
\hline Ventilation & $70.79 \mathrm{Liters} / \mathrm{sec}(150 \mathrm{CFM})$ & $9.44 \mathrm{Liters} / \mathrm{sec}(20 \mathrm{CFM})$ \\
\hline
\end{tabular}

Table 4.3 Structural features of House-B (Barua, 2010)

\begin{tabular}{|c|c|c|}
\hline Features & House-B & In-law suite of House-B \\
\hline Basement walls & RSI 3.54 (R20) with Durisol blocks & RSI 5.31 (R30) \\
\hline walls & RSI 3.54 (R20) with Durisol blocks & RSI 5.31 (R30) \\
\hline Wall insulation & $\begin{array}{c}\text { Heat-lock soya polyurethane foam Lcynene } \\
\text { spray foam }\end{array}$ & $\begin{array}{c}\text { Heat-lock soya polyurethane } \\
\text { foam Lcynene spray foam }\end{array}$ \\
\hline Windows & $\begin{array}{c}1.59 \mathrm{~W} / \mathrm{m}^{2} \mathrm{~K}\left(0.28 \mathrm{Btu} / \mathrm{ft}^{2} .^{\circ} \mathrm{F}\right) \text { and all triple } \\
\text { glazed with argon filled }\end{array}$ & $\begin{array}{c}1.59 \mathrm{~W} / \mathrm{m}^{2} \mathrm{~K}\left(0.28 \mathrm{Btu} / \mathrm{ft}^{2} .^{\circ} \mathrm{F}\right) \\
\text { and all triple glazed with } \\
\text { argon filled }\end{array}$ \\
\hline Roof & $\begin{array}{c}\text { RSI 7 (R40) Structurally Insulated Panels } \\
\text { (SIPs), which are insulated Styrofoam } \\
\text { panels }\end{array}$ & $\begin{array}{c}\text { RSI 7 (R40) Structurally } \\
\text { Insulated Panels (SIPs), which } \\
\text { are insulated Styrofoam panels }\end{array}$ \\
\hline
\end{tabular}

\subsection{Experimental Setup}

A Stirling-engine based micro CHP/Co-gen (combined heat and power) unit is already in service in the basement of House-B. The ClimateWell ${ }^{\circledR}$ chiller was installed and integrated with the existing co-gen unit. The integrated system consumes natural gas and produces electricity, heating and cooling simultaneously; that is why it is termed as tri-generation. Figure 4.2 shows a simple diagram of the residential tri-generation system. The employed co-gen system is a gas based Stirling engine unit manufactured by Whispergen. It consumes natural gas and produces electricity and thermal energy simultaneously. Rejected thermal energy by the co-gen is fed 
directly to the ClimateWell ${ }^{\circledR}$ chiller to produce a cooling effect. The tri-generation system of this project is designed in such a way that maximum portion of the waste heat rejected by the ClimateWell $^{\circledR}$ chiller can be utilized for the preheating of DHW and the rest of it can be rejected to the environment.

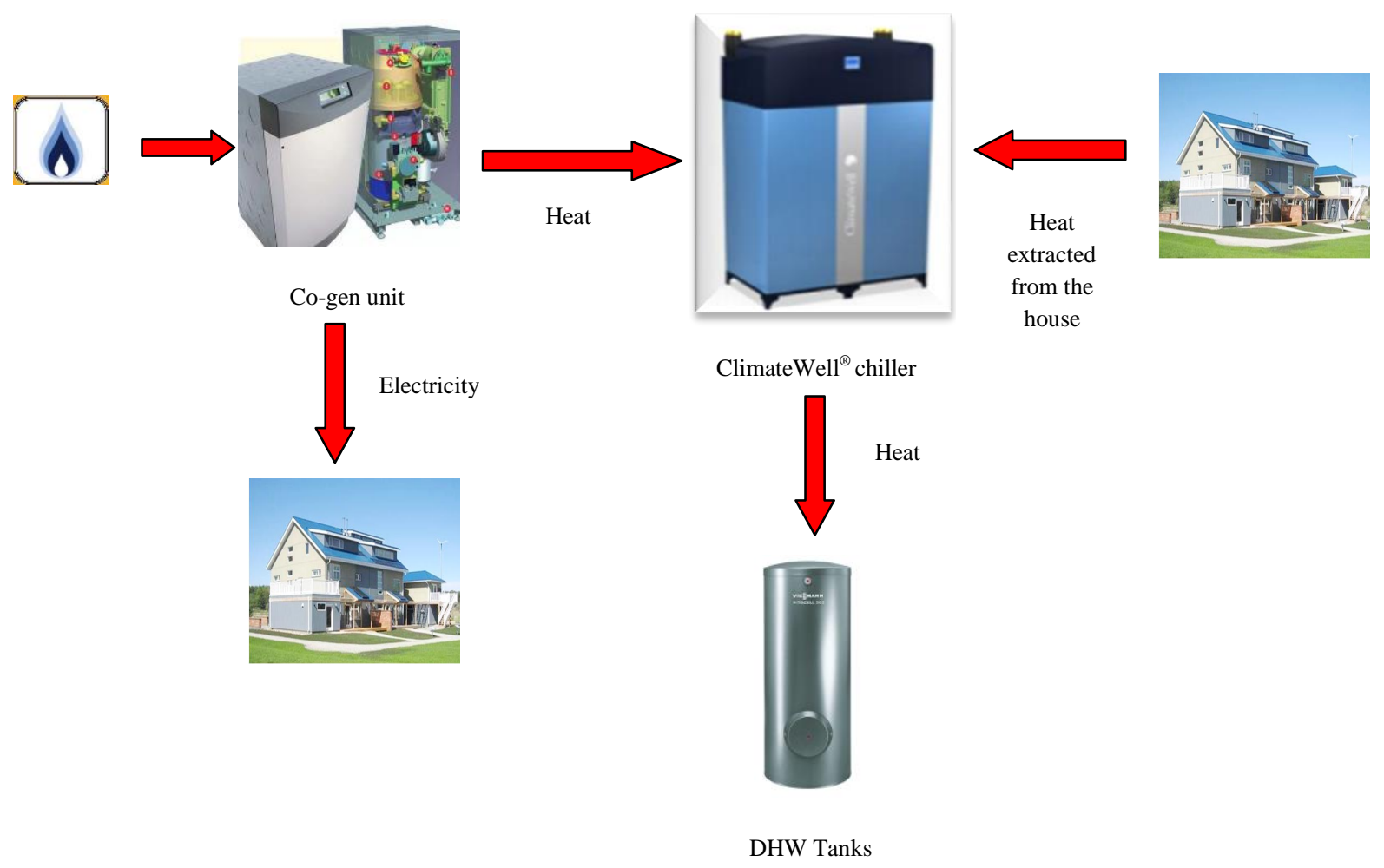

Figure 4.2 Simple diagram of the residential tri-generation system

\subsubsection{Piping and Instrumentation Diagram (P\&ID)}

A detailed P\&ID diagram showing the interconnection among the process equipment and the instrumentation developed is shown in Figure 4.3. In Figure 4.3, pipelines marked with red and blue indicates flow of a high temperature working fluid and a low temperature working fluid respectively. As discussed in Chapter-3, the ClimateWell ${ }^{\circledR}$ chiller needs to be connected with three external circuits namely: the heat source circuit, the heat rejection circuit and the distribution circuit. Details about these three circuits are discussed in this chapter. For the heat rejection circuit, three hot water storage tanks and an outdoor fan coil have been designed to utilize the rejected heat as much as possible. By changing the position of the valves, different possible combinations of heat-rejection are possible. About 20 new temperature and flow sensors 
were used to measure data at different locations of the process. For safety purposes, expansion tanks, air vents, pressure relief valves etc. were installed at different locations of the circuit. The flow control valves used were manually controlled but provisions were kept to fully automate the process in the future by adding actuators and sensors.

In this residential tri-generation system, CHP was used as the heat source, however, provisions to use solar thermal as the heat source in series/parallel with the existing CHP were also kept for future researchers. Similarly, provision was also kept in the heat rejection circuit to connect it with bore holes to dump/store the rejected heat.

A propylene glycol and water mixture of $35 \%$ by volume was used as the working fluid in all three circuits to avoid freezing. As the pipe length of the three circuits is large, it is challenging to charge the whole system from a single point. To overcome this problem, charging points were kept in all three circuits so that they could be charged at the same time.

3/4" copper pipe was used in all three circuits. Pipelines were designed in such a way that it can sustain a maximum of 6-bar operating pressure. An operating pressure of 3 bars was maintained in all three circuits during the experimental work as per ClimateWell ${ }^{\circledR}$ guidelines (ClimateWell, 2009). 


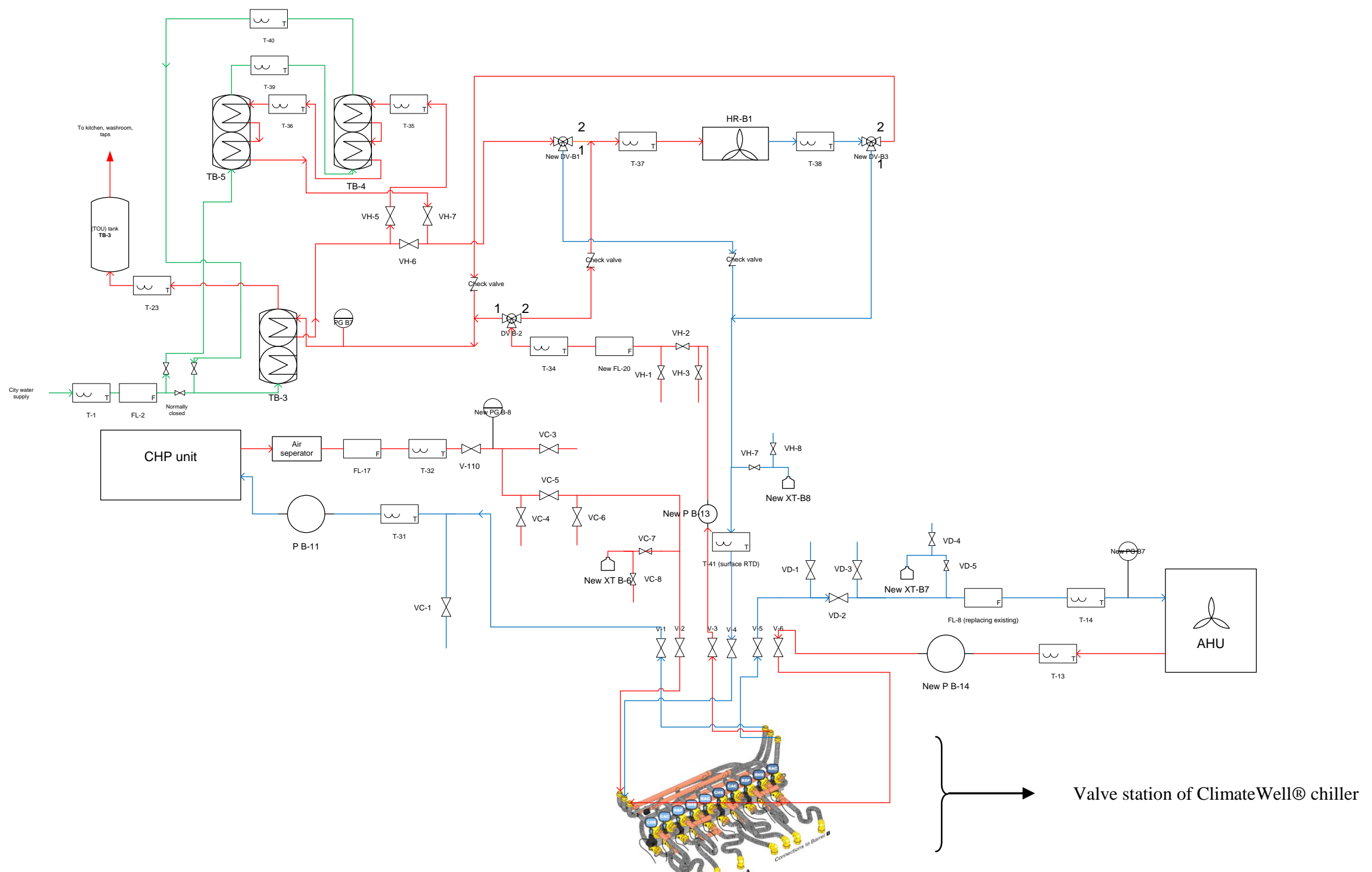

Figure 4.3 P\&ID diagram of the residential tri-generation system 


\subsubsection{Heat Source Circuit}

A suitable heat source is a prerequisite to drive the ClimateWell ${ }^{\circledR}$ chiller. The heat source should meet the minimum charging requirements. The $\mathrm{ClimateWell}^{\circledR}$ chiller is compatible with different heat sources such as: CHP, solar thermal, electric heater, boiler etc. In this residential trigeneration project, a small CHP was used as the heat source. CHP technologies are available in a wide range of power production sizes ranging from a few kilowatts to one megawatt. CHP units designed for domestic purposes produce less than $25 \mathrm{~kW}_{\text {thermal }}$ and less than $10 \mathrm{~kW}_{\text {electrical. }}$. For single family residential houses, smaller CHPs of $14 \mathrm{~kW}_{\text {thermal }}$ and $5 \mathrm{~kW}_{\text {electrical }}$ are suitable (Knight et al., 2005). The CHP unit used in this project is a Stirling-engine based micro CHP (model: PPS24-ACLG-5) manufactured by Whispergen, New Zealand. Figure 4.4 shows the CHP unit and the technical specifications are presented in Table 4.4.

Table 4.4 Technical specifications of CHP unit (Whispergen, 2007)

\begin{tabular}{|c|c|}
\hline Component & Description \\
\hline Engine & 4-cylinder double acting Stirling engine \\
\hline Burner & Single nozzle swirl established recuperation \\
\hline Auxiliary burner & Cylinder premix surface burner \\
\hline Generator & 4-pole single phase induction motor \\
\hline Duty cycle & $1-24$ hours continuous operation \\
\hline Electrical supply & 230 Vac $50 \mathrm{~Hz}$ (nominal grid voltage) \\
\hline Electrical output & Nominal mode up to $1000 \mathrm{~W}$ \\
\hline Thermal Output & Minimum $5 \mathrm{~kW}$, nominal mode up to $7 \mathrm{~kW}$, \\
& maximum $12 \mathrm{~kW}$ \\
\hline Fuel & Natural gas, supply pressure $17-20 \mathrm{mbar}$ \\
\hline Central heating system & Flow rate $8-15 \mathrm{l} / \mathrm{min}$ \\
\hline
\end{tabular}




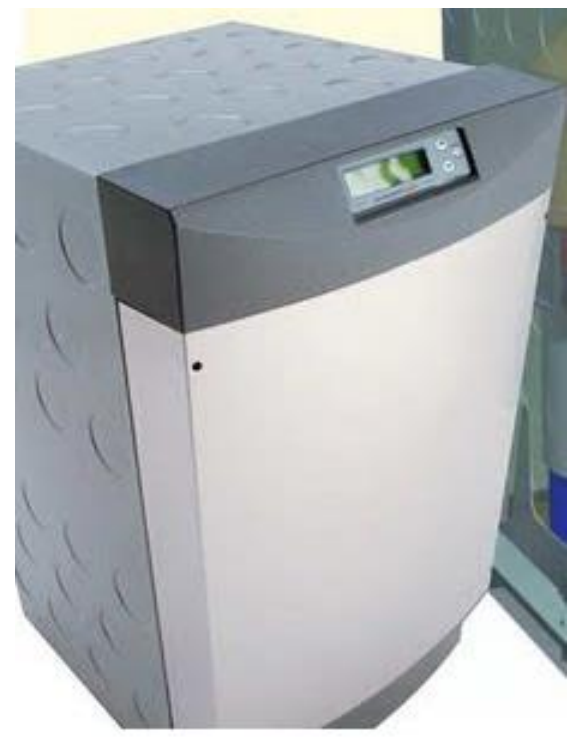

(a)

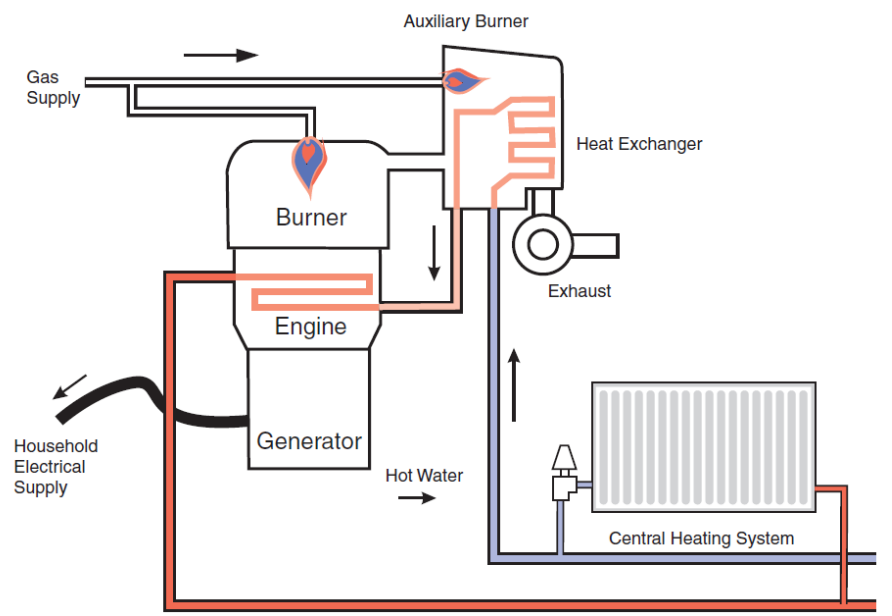

(b)

Figure 4.4 (a) WHISPERGEN CHP unit (b) internal components of the CHP unit

(Whispergen, 2007)

Figure 4.5 shows the P\&ID diagram of the heat-source circuit. It is also termed as the charging circuit of the tri-generation system. The CHP unit is directly coupled with the ClimateWell ${ }^{\circledR}$ chiller via valves V-1 and V-2 without any buffer storage in between. Pump P-B-11 forces the flow through the circuit at a rate of $8-151 / \mathrm{min} .35 \%$ propylene glycol by volume in water was used as the working fluid for the heat source circuit. The circuit also contains a charging point through which the working fluid is charged. An operating pressure of around 3 bars was maintained in the circuit. Temperature sensor T-32 measures the flow temperature from the CHP to the ClimateWell ${ }^{\circledR}$ and T-31 measures the return flow temperature from the ClimateWell ${ }^{\circledR}$ to the CHP. For safety purposes, an expansion vessel XT-B-6 was added in the circuit to allow safe expansion of the working fluid at high temperatures. 


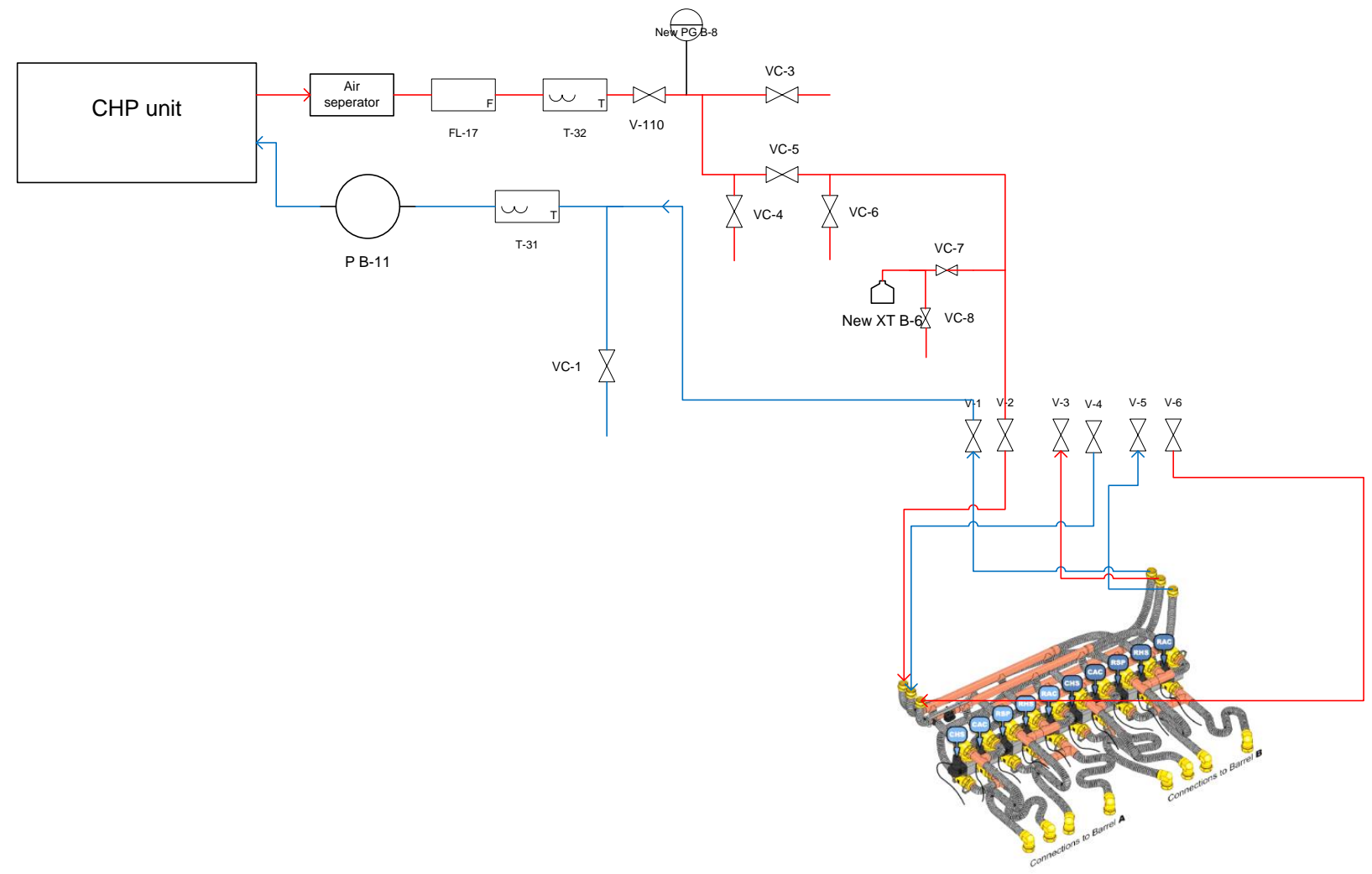

Figure 4.5 P\&ID diagram of the heat source circuit

\subsubsection{Distribution Circuit}

The distribution circuit of the ClimateWell ${ }^{\circledR}$ chiller was connected to the air handling unit of House-B. Figure 4.6 shows the P\&ID diagram of the distribution circuit. The AHU was connected to the ClimateWell ${ }^{\circledR}$ chiller directly via valves V-5 and V-6. Pump P-B-14 forces the flow through the circuit at a rate of 8-12 1/min and the flow meter FL-8 measures the flow rate. Temperature sensor T-14 measures the chilled water supply temperature to the AHU and T-13 measures the chilled water return temperature from the AHU to the chiller. $35 \%$ by volume propylene glycol in water mixture was used as the working fluid and the designed operating pressure in the circuit was about 3 bars. To ensure the maximum temperature drop across the AHU, two AHUs of similar capacity were used in series. The AHUs that were used (model: ZC30) are manufactured by Ecologix and each of them has a cooling capacity of about 2.48 ton (9.85 kW) (Ecologix, 2011-2012). 


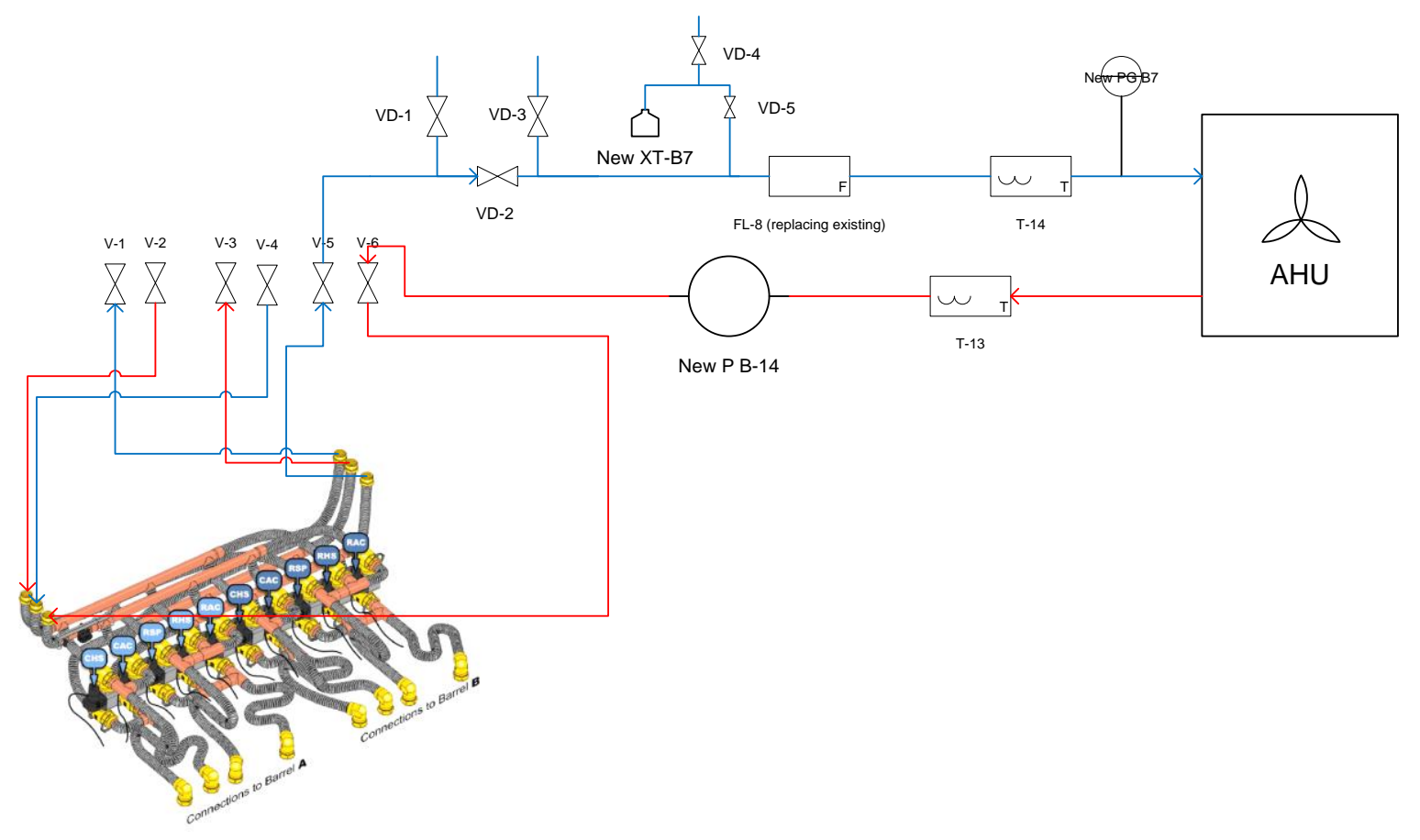

Figure 4.6 P\&ID diagram of the distribution circuit

\subsubsection{Heat Rejection Circuit}

The efficiency of the ClimateWell ${ }^{\circledR}$ chiller largely depends on the efficiency of the heat rejection system. So, the heat rejection circuit should be designed in such a way that it can remove the entire portion of the rejected heat efficiently from the chiller. The heat rejection temperature of the ClimateWell ${ }^{\circledR}$ chiller is roughly $55-65^{\circ} \mathrm{C}$ lower than the heat source temperature. As the supply temperature from the $\mathrm{CHP}$ is within the range of $85-100^{\circ} \mathrm{C}$, the heat rejection temperature is within the range of $30-40^{\circ} \mathrm{C}$. According to the design guidelines, the heat rejection flow should be cooled down below $30^{\circ} \mathrm{C}$ (ClimateWell, 2009) and it is challenging to do so, especially during hot summer days.

The ClimateWell ${ }^{\circledR}$ chiller rejects a large amount of low grade heat both during the charging and the discharge cycle. During charging of both barrels, it theoretically rejects a total of $30 \mathrm{kWh}$ of 
heat (per barrel) and during the discharge cycle, it rejects $44 \mathrm{kWh}$ of heat energy (per barrel). Figure 4.7 shows the theoretical energy conservation of the ClimateWell ${ }^{\circledR}$ chiller during both charging and discharge cycles.

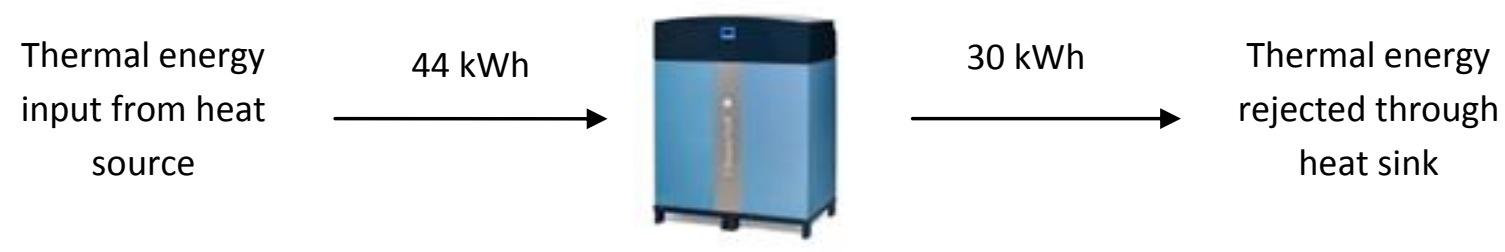

(a)

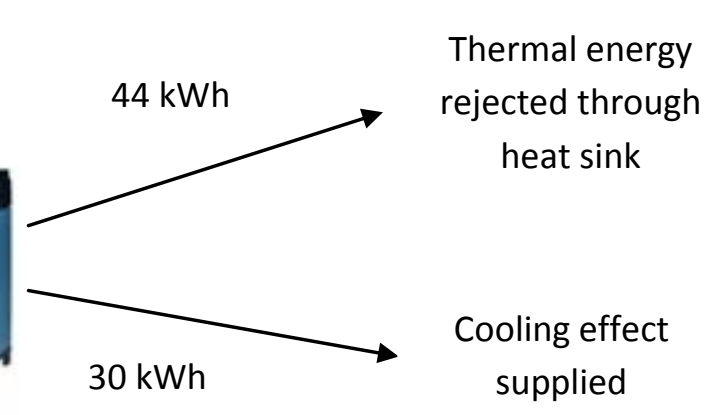

(b)

\section{Figure 4.7 Theoretical energy conservation per barrel during charging cycle (b) Theoretical energy conservation per barrel during discharge cycle}

Utilizing the substantial amount of rejected heat by the ClimateWell ${ }^{\circledR}$ chiller can reduce the total energy consumption of the house and thus can increase the overall efficiency of the trigeneration system. One of the objectives of this research is to find different possible ways of utilizing the rejected heat.

To maximize the benefit from the tri-generation system, effective energy storage devices are required that can utilize the rejected heat from the chiller. A multi-tank thermal storage system is one of the attractive ways as it is modular, low cost and ease to install. In a multi tank thermal storage system, several DHW tanks are coupled together in a single hydraulic unit (Mather et al., 2002). Multiple tanks can be plumbed either in series or in parallel as shown in Figure 4.8. For 
this residential tri-generation project, an in series orientation as shown in Figure 4.8(b) was chosen as it allows higher stratification of temperature (Cruickshank, 2009). Moreover, it requires less supply of cooling water in the counter flow manner as compared to the parallel configuration.

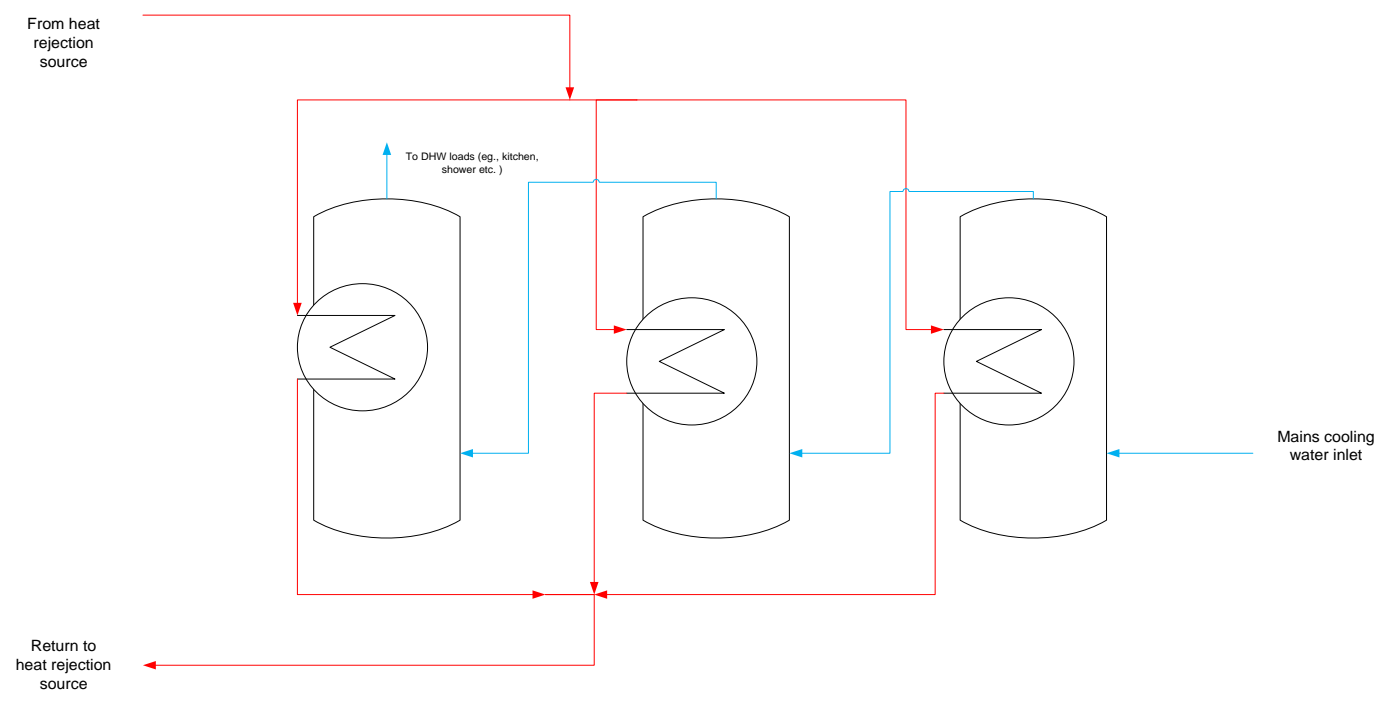

(a)

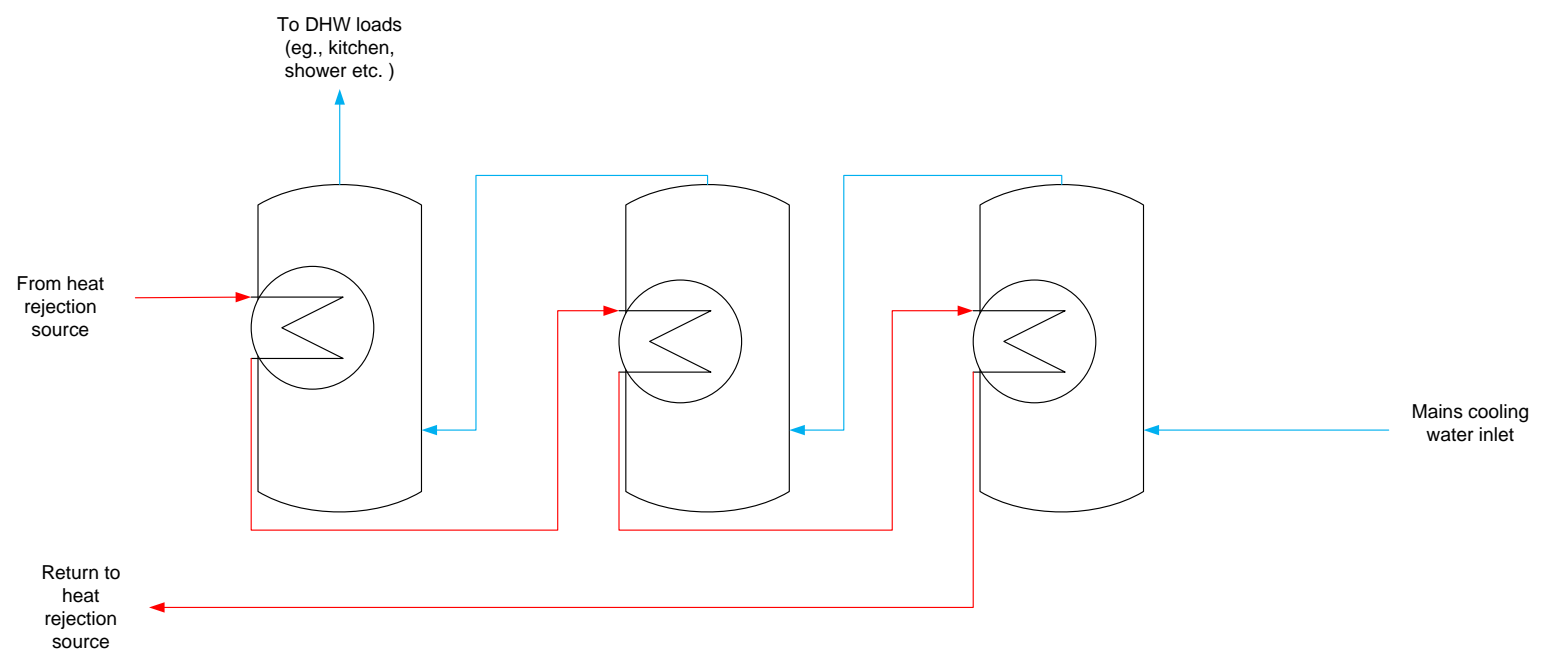

(b)

Figure 4.8 (a) Multiple DHW tank are connected in parallel (b) Multiple DHW tanks are connected in series configuration 
To extract and utilize the maximum amount of the rejected energy, three DHW tanks and an outdoor fan coil were used in this project. The heat rejection circuit was designed in such a way that several combinations of tanks and fan coil are possible to store/utilize the rejected heat. Moreover, utilizing the rejected heat to preheat the domestic hot water also reduces the cost and the energy required for DHW heating. Depending on the outdoor temperature, different combinations of tanks and fan coil will ensure maximum utilization of the rejected heat to produce domestic hot water and then a small portion of the energy that cannot be utilized further will be rejected to the atmosphere via the fan coil.

Figure 4.10 shows the P\&ID diagram of the heat rejection circuit. Three 3-way valves and three check valves were used to divert the flow in different directions for different combinations of $\operatorname{tank}(\mathrm{s})$ and fan coil. Three DHW tanks namely: TB-3, TB-4 and TB-5 each of 300 L capacity were used for DHW production using the rejected heat. As shown in Figure 4.9, each tank contains two immersed heat-exchangers, one at the top and the other one at the bottom. For tank TB-3, only the top heat exchanger was used and for tanks TB-4 and TB-5, both the heat exchangers were used for heat rejection purpose. The heat rejection circuit was designed in such a way that depending on the DHW demand, either 1 tank, 2 tanks, or 3 tanks can be used for DHW production and in the case of low DHW demand the entire rejected heat can be released to the atmosphere via the fan coil unit. Table 4.5 shows the valve positions for different combinations of heat rejection.

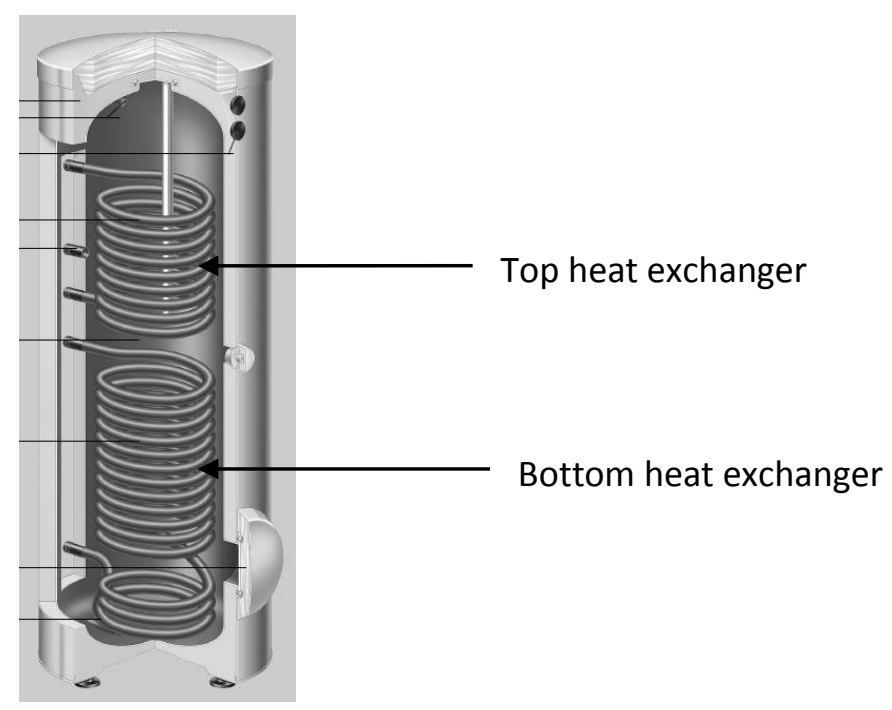

Figure 4.9 Cross section of the DHW tanks used for heat rejection 


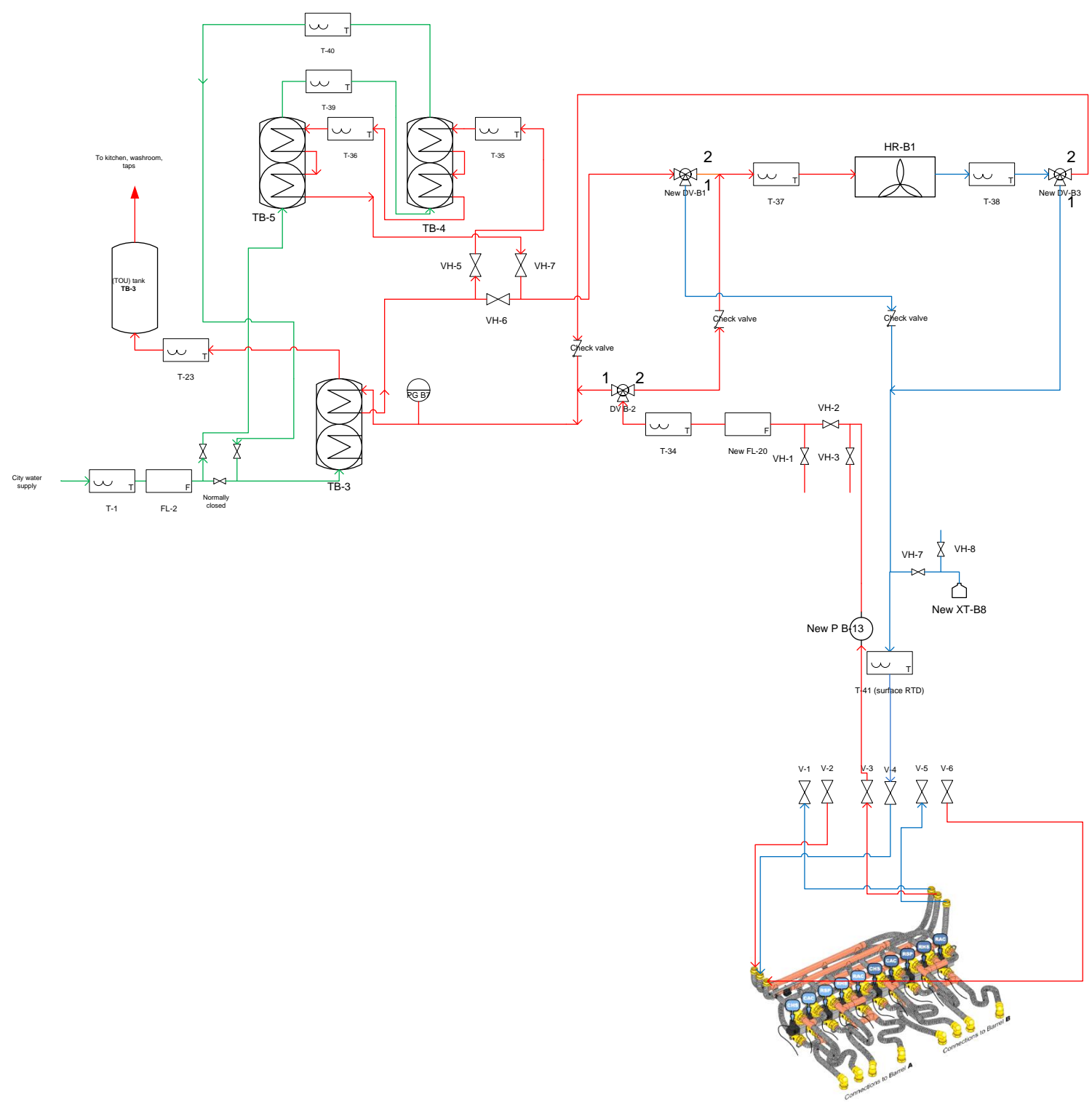

Figure 4.10 P\&ID of the heat rejection circuit 
Table 4.5 Valve position for different combination of heat rejection

\begin{tabular}{|l|c|c|c|c|c|c|}
\hline \multicolumn{1}{|c|}{ Combinations } & \multicolumn{7}{c|}{ Valve position } \\
\cline { 2 - 7 } & DV-B1 & DV-B2 & DV-B3 & VH5 & VH6 & VH7 \\
\hline $\begin{array}{l}\text { Heat is rejected to three tanks first } \\
\text { and then to the outdoor fan coil }\end{array}$ & 2 & 1 & 1 & Open & Closed & Open \\
\hline $\begin{array}{l}\text { Heat is rejected to fan coil first } \\
\text { and then to the three tanks }\end{array}$ & 1 & 2 & 2 & Open & Closed & Open \\
\hline $\begin{array}{l}\text { Heat is rejected to three tanks } \\
\text { only }\end{array}$ & 1 & 1 & Closed & Open & Closed & Open \\
\hline Heat is rejected to fan coil only & closed & 2 & 1 & Open & Closed & Open \\
\hline Heat is rejected to tank TB-3 only & 1 & 1 & Closed & Closed & Open & Closed \\
\hline $\begin{array}{l}\text { Heat is rejected to tank TB-3 and } \\
\text { then to fan coil }\end{array}$ & 2 & 1 & 1 & Closed & Open & Closed \\
\hline $\begin{array}{l}\text { Heat is rejected to fan coil first } \\
\text { and then to tank TB-3 }\end{array}$ & 2 & 2 & 2 & Closed & Open & Closed \\
\hline
\end{tabular}




\subsection{Commissioning of the Tri-generation System}

Commissioning of the ClimateWell ${ }^{\circledR}$ chiller and other process equipment was carried out jointly by the professionals from the Renteknik Group Inc. and the TRCA. Renteknik Group Inc. is the distributor of ClimateWell ${ }^{\circledR}$ chillers in North America. Also they have previously installed and commissioned ten ClimateWell ${ }^{\circledR}$ chillers at Schouldice Hospital in Markham, Ontario. As TRCA staff wanted to showcase the project to the public, a convenient corner in the basement of the House-B was selected. The heat rejection loop is the largest circuit in the system that contains tanks, the fan coil, sensors and other process equipment. To decrease the pipe length in the heat rejection loop, tank TB-4 and TB-5 were placed close to the chiller as shown in Figure 4.10.
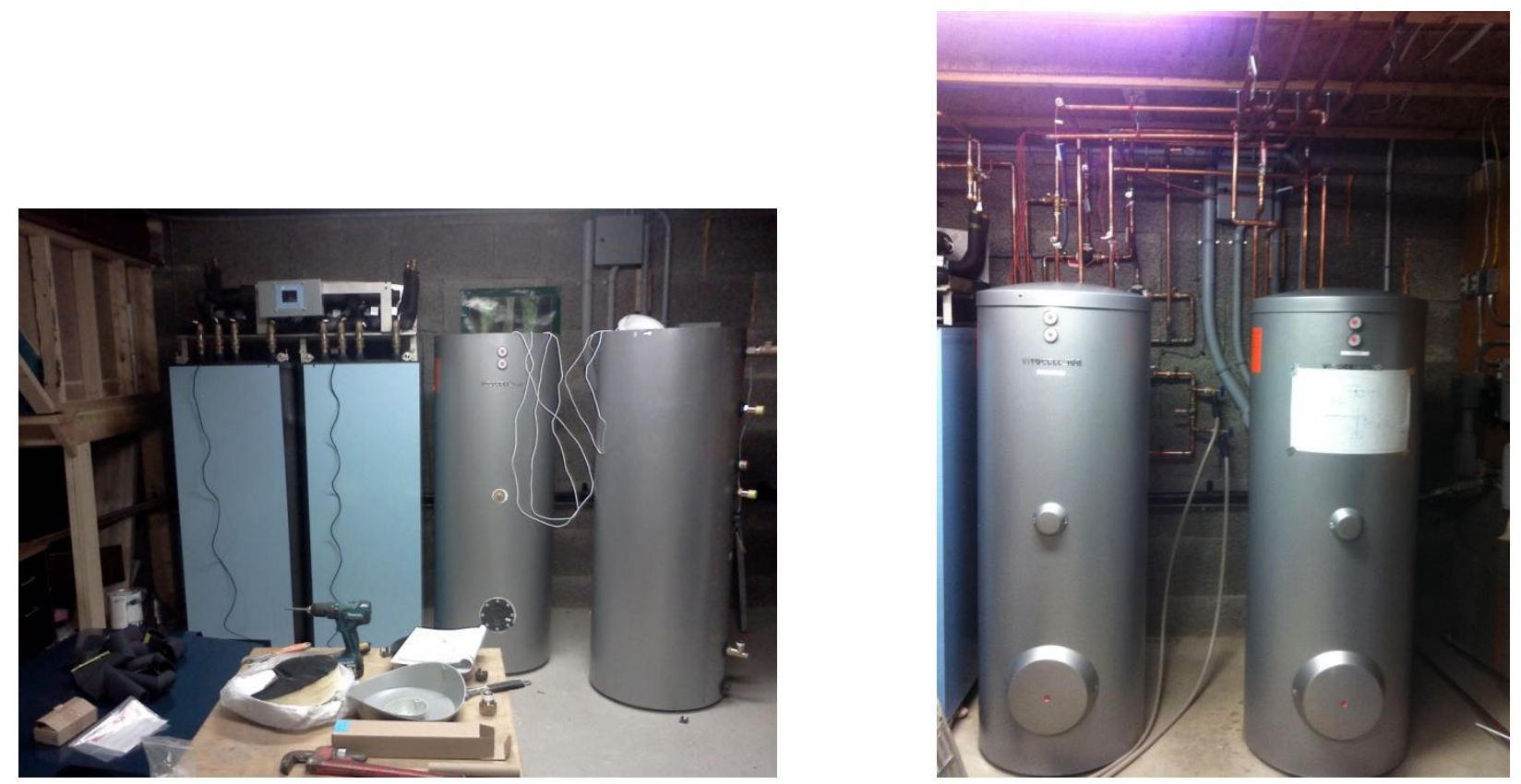

Fig. 4.10 Heat rejection circuit (before insulating)

ClimateWell $^{\circledR}$ chillers are not properly vacuum sealed when they are shipped and this is due to safety concerns during transportation. So, after installation of the chiller, the vacuum was tested and the unit was properly vacuum sealed as per the installation manual (ClimateWell, 2010). Safety valves, pressure gauges and air vents were installed at different points of the circuits for safety. After installation of all the process equipment, all three circuits were charged with the working fluid (35\% propylene glycol by volume in water). At the first try, charging could not be 
made properly due to trapped air in all the three circuits. Air removal was not possible manually as it was time consuming. So, an automatic air separator was installed in the heat rejection loop.

The existing AHU as shown in Figure 4.11(b) has a cooling capacity of $8.73 \mathrm{~kW}$ (2.48 ton). The ClimateWell $^{\circledR}$ chiller has a cooling capacity of $20 \mathrm{~kW}(5.68$ ton $)$ when both barrels are in operation. As shown in Figure 4.11 (a), two similar AHUs were used in series. This configuration allows high residence time for the chilled water in the AHU and thus maximum extraction of the cooling capacity is possible. As the experiments were carried out at the beginning of winter (October-December), to create artificial cooling demand, House-B was heated up by the ground source heat pump (GSHP) through the use of the in-floor heating system.

Upon installation and commissioning, the ClimateWell ${ }^{\circledR}$ chiller was calibrated as per guidelines. Pipelines of all the three circuits were also insulated to minimize system losses.

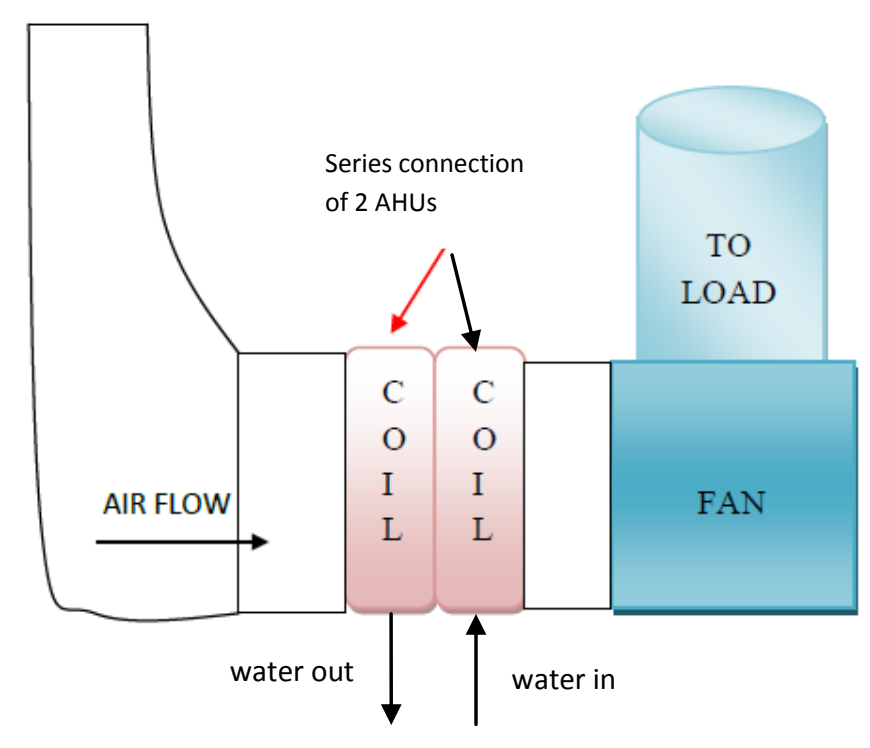

(a)

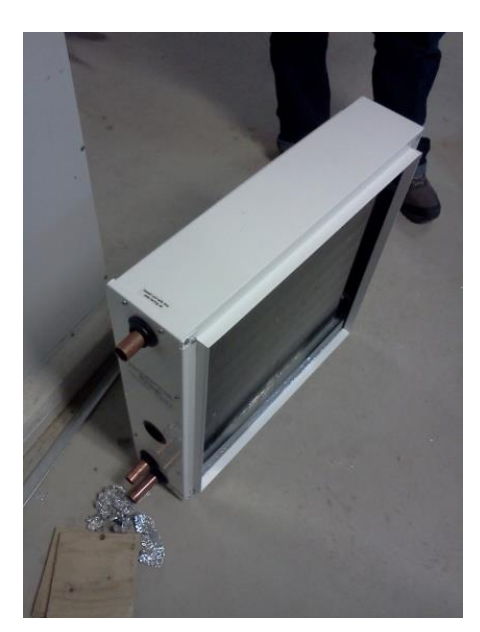

(b)

Figure 4.11 (a) Series connection of two AHUs (b) AHU used in this project 


\subsection{Sensors}

In this residential tri-generation project, over 20 new temperature and flow sensors were installed to measure data at different points of the process. Sensors installation was carried out as per the manufacturer's guidelines to avoid any electrical damage or inaccurate readings. Table 4.6 shows the list of sensor types that were used with their required input. The connections between sensors and the connector block of the data acquisition (DAQ) system were carried out as per National Instruments (NI) supplied circuit diagram (Zhang et al., 2011). The accuracy level of different sensors used is included in Appendix-B.

Table 4.6 List of sensor types and their input parameters (Tanha, 2011)

\begin{tabular}{|c|c|c|}
\hline & Input parameters & Sensor types \\
\hline CHP unit & $\begin{array}{c}\text { Gas flow rate, exhaust gas } \\
\text { temperature, supply and return } \\
\text { working fluid temperature and } \\
\text { flow rate, power consumption }\end{array}$ & $\begin{array}{c}\text { RTD probe, air flow sensors, } \\
\text { natural gas meter, liquid flow } \\
\text { rate sensor and wattnode } \\
\text { sensor }\end{array}$ \\
\hline $\begin{array}{c}\text { Heat source circuit, heat } \\
\text { rejection circuit and } \\
\text { distribution circuit }\end{array}$ & $\begin{array}{c}\text { Working fluid (water and } \\
\text { propylene glycol mix) } \\
\text { temperature and flow rate }\end{array}$ & $\begin{array}{c}\text { RTD probe, liquid flow rate } \\
\text { sensor }\end{array}$ \\
\hline
\end{tabular}

\subsubsection{Temperature Sensors}

Three types of RTD temperature sensors were used in this project, namely: Pt-500 series immersed delta-T RTD sensors, Pt-100 series direct immersed RTD sensors, and Pt-100 series surface mounted temperature sensors. For calibration purposes, two sources of reference temperature were used, i.e. (a) ice water and (b) handheld dry-wells (Barua, 2010).

\subsubsection{Liquid Flow Meters}

Two types of liquid flow meters were used in this project, namely: (a) turbine type water flow rate sensors and (b) PROTEUS series flow rate sensors. Turbine type flow meters are used to measure the water supply from the main line. Turbine type flow sensors are manufactured by GEMS and are capable of reading a wide range of flow rates from as low as $0.51 / \mathrm{min}$ to 30 $1 /$ min. PROTEUS sensors were used in the heat source, heat rejection and distribution circuits as these circuits have high-temperature flow and PROTEUS sensors are more compatible with high temperature flow. 


\subsubsection{Calibration of Sensors}

For calibration process of all temperature sensors, the off-line calibration technique was applied (Barua, 2010). In the process of off-calibration, the collected data has two components: raw sensor readings and data captured by a high quality and high precision calibrator measuring the same set of data. The goal of the off-line calibration is to determine a function that provides the mapping from the raw sensor reading to correct values (Feng et al., 2003). All the sensors were calibrated before the start of data collection and testing. A HART Scientific series 9102S Handheld dry-well calibrator was used to calibrate the temperature sensors and PROTEUS flow sensors were factory calibrated but still were cross checked. The accuracy levels of different calibrators used in this project are listed in Appendix-B.

\subsection{Data Acquisition System (DAQ)}

National Instrument's data acquisition hardware and LabView software have been used in this project. The DAQ system consists of a backplane, controller, module, connector block, power supplier, LabView software platform and a central computer. A National Instrument's compact fieldpoint (CFP) system has been used in this project. This CFP system consists of rigid I/O modules and an intelligent communication interface that filters, calibrates and scales raw sensor signals as well as performs self-diagnostics. All CFPs are connected to the central computer through a network hub. The output signals of sensors are converted to corresponding engineering units by means of LabView software (Zhang et al., 2011). LabView software collects all sensor data continuously at a constant sampling time of 5 seconds.

In order to store data, an SQL server management studio has been used in this project. This software is capable of dealing with large volume of data. This software has the database capacity of 524272 TB (SQL server, 2008). All the collected data from LabView is stored in the SQL server database directly. Whenever needed, the user can easily store, retrieve and manipulate data in this software. 


\subsection{Energy Consumption, Generation and Efficiency Equations of the Tri- generation system}

The basic equations for energy, heat transfer and efficiency calculations of different equipment of the tri-generation system are discussed in this section. The sources of basic equations are the ASHRAE handbook, manuals, various books and articles (ASHRAE Guideline 2, 2005).

\subsubsection{Propylene Glycol (PG) Solution}

To avoid freezing, a propylene glycol and water solution (35:65) was used as the working fluid in this tri-generation project. This solution has freezing point of $-18^{\circ} \mathrm{C}$.

The properties of propylene glycol water solution at different temperatures are given in Appendix-C. It is observed that the density of the 35:65 PG solution changes only 0.5\%-1.1\% per $10^{\circ} \mathrm{C}$ change in temperature and specific heat changes only $1 \%$ per $10^{\circ} \mathrm{C}$ change in temperature (Thermal \& Mechanical Equipment Company (TMEC), 2012). So, for the simplicity of calculations, average data was used.

\subsubsection{CHP Unit}

Thermal energy is extracted from the CHP unit by means of supplying a working fluid around the combustion chamber. The thermal power generation rate of the CHP unit is obtained by Equation (4-1).

$\dot{Q}_{\text {Thermal }}=\dot{\mathrm{m}}_{\mathrm{wf}} \times \mathrm{C}_{\mathrm{P}, \mathrm{wf}} \times\left(\mathrm{T}_{\text {supply }}-\mathrm{T}_{\text {return }}\right)=\rho_{\mathrm{wf}} \times \mathrm{V}_{\mathrm{wf}} \times \mathrm{C}_{\mathrm{P}, \mathrm{wf}} \times\left(\mathrm{T}_{\text {supply }}-\mathrm{T}_{\text {return }}\right)$

Where, $\dot{\mathrm{m}}_{\mathrm{wf}}, \rho_{\mathrm{wf}}, \mathrm{V}_{\mathrm{wf}}$ and $\mathrm{C}_{\mathrm{P}, \mathrm{wf}}$ are mass flow rate, density, volume flow rate and specific heat of the working fluid respectively. $\mathrm{T}_{\text {supply }}$ and $\mathrm{T}_{\text {return }}$ are the supply and return temperature from the CHP side. As $\mathrm{T}_{\text {supply }}$ and $\mathrm{T}_{\text {return }}$ are within the range of $80^{\circ} \mathrm{C}-110^{\circ} \mathrm{C}$, using the average value of $\mathrm{C}_{\mathrm{P}, \mathrm{wf}}$ and $\rho_{\mathrm{wf}}$, in Equation (4-1) can be written as:

$\dot{Q}_{\text {Thermal }}=1005.7\left(\mathrm{~kg} / \mathrm{m}^{3}\right) \times \mathrm{FL} 17(1 / \mathrm{min}) \times 3821(\mathrm{~J} / \mathrm{kg} . \mathrm{K}) \times\left[\mathrm{T}_{32}-\mathrm{T}_{31}\right](\mathrm{K}) \times\left|\frac{10^{-3} \mathrm{~m}^{3}}{l}\right| \times\left|\frac{1 \mathrm{~min}}{60 \mathrm{~s}}\right|$

Total thermal energy supplied by the CHP unit over a time period can be expressed as:

$\mathrm{Q}_{\text {Thermal }}=\int \frac{\dot{Q}_{\text {Thermal }}}{60} \times d t$ 
Thermal efficiency of the CHP can be expressed below:

$\eta=\frac{Q_{\text {Thermal }}}{\text { volume or mass of } N G \text { in a given time } \times H H V^{1}} \times 100$

HHV of natural gas is $37.8\left(\frac{M J}{m^{3}}\right)$ (Union Gas, 2013).

\subsubsection{Cooling Capacity of the ClimateWell ${ }^{\circledR}$ Chiller}

The ClimateWell ${ }^{\circledR}$ chiller produces a cooling effect by supplying a chilled working fluid to the AHU. House-B provides a cooling load and thus increases the chilled water temperature through the AHU. The cooling effect supplied by the chiller is expressed by Equation (4-5).

$\dot{Q}_{\text {Cooling }}=\dot{\mathrm{m}}_{\mathrm{wf}} \times \mathrm{C}_{\mathrm{P}, \mathrm{wf}} \times\left(\mathrm{T}_{\text {return }}-\mathrm{T}_{\text {supply }}\right)=\rho_{\mathrm{wf}} \times \mathrm{V}_{\mathrm{wf}} \times \mathrm{C}_{\mathrm{p}, \mathrm{wf}} \times\left(\mathrm{T}_{\text {return }}-\mathrm{T}_{\text {supply }}\right)$

Where, $\dot{\mathrm{m}}_{\mathrm{wf}}, \rho_{\mathrm{wf}}, \mathrm{V}_{\mathrm{wf}}$ and $\mathrm{C}_{\mathrm{P} \text {, wf }}$ are mass flow rate, density, volume flow rate and the specific heat of the working fluid respectively. $\mathrm{T}_{\text {supply }}$ is the chilled water supply temperature by the chiller and $T_{\text {return }}$ is the temperature of the working fluid returned to the chiller. As $T_{\text {supply }}$ and $T_{\text {return }}$ are within the range of $5^{\circ} \mathrm{C}-20^{\circ} \mathrm{C}$, using the average value of $\mathrm{C}_{\mathrm{P}, \mathrm{wf}}$ and $\rho_{\mathrm{wf}}$, Equation (4-6) can be written as:

$\dot{Q}_{\text {Cooling }}=1063.9\left(\mathrm{~kg} / \mathrm{m}^{3}\right) \times \mathrm{FL} 8(1 / \mathrm{min}) \times 3503(\mathrm{~J} / \mathrm{kg} . \mathrm{K}) \times\left[\mathrm{T}_{13}-\mathrm{T}_{14}\right](\mathrm{K}) \times\left|\frac{10^{-3} \mathrm{~m}^{3}}{l}\right| \times\left|\frac{1 \mathrm{~min}}{60 \mathrm{~s}}\right|$

Total cooling energy supplied by the chiller over a time period can be expressed as:

$\mathrm{Q}_{\text {Cooling }}=\int \frac{\dot{Q}_{\text {Cooling }}}{60} \times d t$

The Coefficient of performance (COP) of the absorption chiller is the ratio of the cooling effect to the thermal input. The COP of the ClimateWell ${ }^{\circledR}$ chiller is expressed by Equation (4-8). The theoretical COP of a TCA using $\mathrm{LiCl}-\mathrm{H}_{2} \mathrm{O}$ is 0.68 under a perfect vacuum condition and the manufacturer claims that the ClimateWell ${ }^{\circledR}$ chiller has a COP within the range of 0.52-0.57 and the COP depends on installation characteristics (ClimateWell, 2009).

$\operatorname{COP}_{\text {Thermal }}=\frac{\text { Cooling effect }}{\text { Heat input }}=\frac{Q_{\text {Cooling }}}{Q_{\text {Thermal }}}$

\subsubsection{Heat Rejection Circuit}

The heat rejection circuit is the longest circuit in the tri-generation system and it contains 10 sensors altogether. The heat rejection circuit is continuously in operation as the chiller rejects 
heat both during charging and discharging. The rate of heat rejection can be calculated by Equation (4-9) as below:

$\dot{Q}_{\text {Rejection }}=\dot{\mathrm{m}}_{\mathrm{wf}} \times \mathrm{C}_{\mathrm{P}, \mathrm{wf}} \times\left(\mathrm{T}_{\text {supply }}-\mathrm{T}_{\text {return }}\right)=\rho_{\mathrm{wf}} \times \mathrm{V}_{\mathrm{wf}} \times \mathrm{C}_{\mathrm{P}, \mathrm{wf}} \times\left(\mathrm{T}_{\text {supply }}-\mathrm{T}_{\text {return }}\right)$

Where, $\dot{\mathrm{m}}_{\mathrm{wf}}, \rho_{\mathrm{wf}}, \mathrm{V}_{\mathrm{wf}}$ and $\mathrm{C}_{\mathrm{P} \text {, wf }}$ are mass flow rate, density, volume flow rate and specific heat of the working fluid respectively. $\mathrm{T}_{\text {supply }}$ is the temperature of hot water flow from the chiller and $\mathrm{T}_{\text {return }}$ is the temperature of cooling water flow returned to the chiller. As $\mathrm{T}_{\text {supply }}$ and $\mathrm{T}_{\text {return }}$ are within the range of $30^{\circ} \mathrm{C}-45^{\circ} \mathrm{C}$, using the average value of $\mathrm{C}_{\mathrm{P}, \mathrm{wf}}$ and $\rho_{\mathrm{wf}}$, in Equation (4-9) can be written as:

$\dot{Q}_{\text {Rejection }}=1049.6\left(\mathrm{~kg} / \mathrm{m}^{3}\right) \times \mathrm{FL} 20(1 / \mathrm{min}) \times 3599(\mathrm{~J} / \mathrm{kg} . \mathrm{K}) \times\left[\mathrm{T}_{34}-\mathrm{T}_{39}\right](\mathrm{K}) \times\left|\frac{10^{-3} \mathrm{~m}^{3}}{l}\right| \times\left|\frac{1 \mathrm{~min}}{60 \mathrm{~s}}\right|(\mathrm{W})$

Total heat rejection can be expressed as:

$\mathrm{Q}_{\text {Rejection }}=\int \frac{\dot{Q}_{\text {Rejection }}}{60} \times d t$

As discussed before, in the heat-rejection circuit, three tanks TB-3, TB-4 and TB-5 are connected in series and heat is first rejected to TB-3, then to tank TB-4 and at last to tank TB-5; while cooling water from the main line flows in the counter flow direction. Energy conservation in each tanks is shown in Figure 4.12.

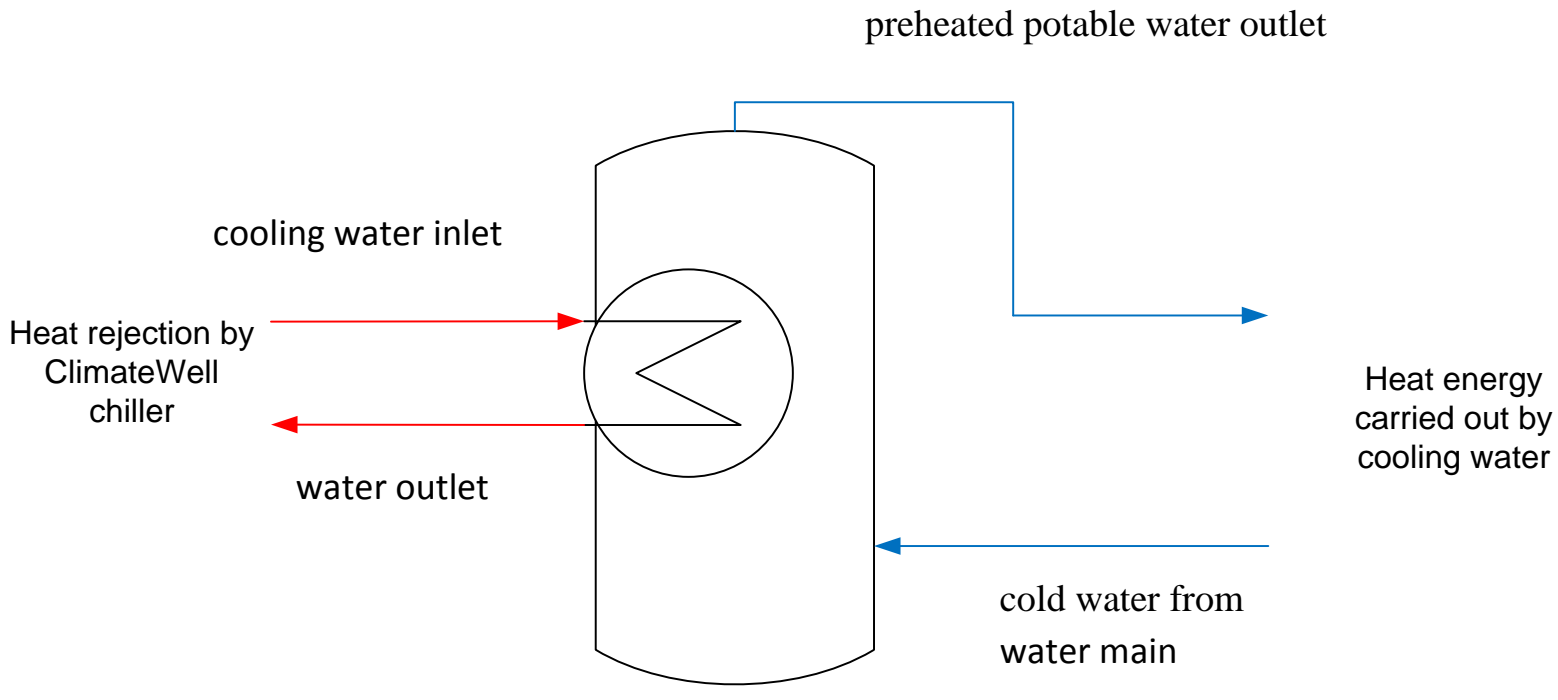

Fig. 4.12 Energy conservation in DHW tanks 
The rate of heat energy supplied to tank TB-3 can be expressed by Equation (4-11) as below:

$\dot{Q}_{\mathrm{TB} 3 \text { (supplied) }}=1049.6\left(\mathrm{~kg} / \mathrm{m}^{3}\right) \times \mathrm{FL} 20(\mathrm{l} / \mathrm{min}) \times 3599(\mathrm{~J} / \mathrm{kg} . \mathrm{K}) \times\left[\mathrm{T}_{34}-\mathrm{T}_{35}\right](\mathrm{K}) \times\left|\frac{10^{-3} \mathrm{~m}^{3}}{l}\right| \times\left|\frac{1 \mathrm{~min}}{60 \mathrm{~s}}\right|(\mathrm{W})(4-12)$

The heat energy carried away from tank TB-3 by the water main's cooling water can be expressed by Equation (4-12) as below:

$\dot{Q}_{\mathrm{TB} 3(\mathrm{removed})}=1061.25\left(\mathrm{~kg} / \mathrm{m}^{3}\right) \times \mathrm{FL} 2(1 / \mathrm{min}) \times 3522(\mathrm{~J} / \mathrm{kg} . \mathrm{K}) \times\left[\mathrm{T}_{1}-\mathrm{T}_{23}\right](\mathrm{K}) \times\left|\frac{10^{-3} \mathrm{~m}^{3}}{l}\right| \times\left|\frac{1 \mathrm{~min}}{60 \mathrm{~s}}\right|(\mathrm{W})(4-13)$

The rate of heat energy stored in tank TB-3 can be expressed by Equation (4-13)

$\dot{Q}_{\mathrm{TB} 3(\text { stored })}=\dot{Q}_{\mathrm{TB} 3 \text { (supplied) }}-\dot{Q}_{\mathrm{TB} 3 \text { (removed) }}$

Total energy stored in tank TB-3 can be expresses as below:

$\mathrm{Q}_{\mathrm{TB} 3(\mathrm{total})}=\int \frac{\dot{Q}_{\mathrm{TB} 3(\text { stored })}}{60} \times d t$

$(\mathrm{kWh})$

Similarly, for tank TB-4, the equations are as below:

$\dot{Q}_{\mathrm{TB} 4(\text { supplied })}=1049.6\left(\mathrm{~kg} / \mathrm{m}^{3}\right) \times \mathrm{FL} 20(\mathrm{l} / \mathrm{min}) \times 3599(\mathrm{~J} / \mathrm{kg} . \mathrm{K}) \times\left[\mathrm{T}_{35}-\mathrm{T}_{36}\right](\mathrm{K}) \times\left|\frac{10^{-3} \mathrm{~m}^{3}}{l}\right| \times\left|\frac{1 \mathrm{~min}}{60 \mathrm{~s}}\right|(\mathrm{W})(4-16)$

$\dot{Q}_{\mathrm{TB} 4(\mathrm{removed})}=1061.3\left(\mathrm{Kg} / \mathrm{m}^{3}\right) \times \mathrm{FL} 2(\mathrm{l} / \mathrm{min}) \times 3522(\mathrm{~J} / \mathrm{Kg} . \mathrm{K}) \times\left[\mathrm{T}_{39}-\mathrm{T}_{40}\right](\mathrm{K}) \times\left|\frac{10^{-3} \mathrm{~m}^{3}}{l}\right| \times\left|\frac{1 \mathrm{~min}}{60 \mathrm{~s}}\right|(\mathrm{W})(4-17)$

$\dot{Q}_{\mathrm{TB} 4(\text { stored })}=\dot{Q}_{\mathrm{TB} 4 \text { (supplied) }}-\dot{Q}_{\mathrm{TB} 4 \text { (removed) }}$

$\mathrm{Q}_{\mathrm{TB} 4 \text { (total) }}=\int \frac{\dot{Q}_{\mathrm{TB} 4 \text { (stored) }}}{60} \times d t$

$(\mathrm{kWh})$

For tank TB-5, the equations are as below:

If both the fan coil and the three tanks are used for heat rejection, then the rate of heat energy rejected to tank TB-5 can be expressed by Equation (4-20)

$\dot{Q}_{\mathrm{TB} 5(\text { supplied) }}=1049.6\left(\mathrm{~kg} / \mathrm{m}^{3}\right) \times \mathrm{FL} 20(1 / \mathrm{min}) \times 3599(\mathrm{~J} / \mathrm{kg} . \mathrm{K}) \times\left[\mathrm{T}_{36}-\mathrm{T}_{37}\right](\mathrm{K}) \times\left|\frac{10^{-3} \mathrm{~m}^{3}}{l}\right| \times\left|\frac{1 \mathrm{~min}}{60 \mathrm{~s}}\right|(\mathrm{W})(4-20)$

If only three tanks are used for heat rejection, then the rate of energy rejected to tank TB-5 can be expressed by Equation (4-21) as below: 
$\dot{Q}_{\mathrm{TB} 5 \text { (supplied) }}=1049.6\left(\mathrm{~kg} / \mathrm{m}^{3}\right) \times \mathrm{FL} 20(\mathrm{l} / \mathrm{min}) \times 3599(\mathrm{~J} / \mathrm{kg} . \mathrm{K}) \times\left[\mathrm{T}_{36}-\mathrm{T}_{41}\right](\mathrm{K}) \times\left|\frac{10^{-3} \mathrm{~m}^{3}}{l}\right| \times\left|\frac{1 \mathrm{~min}}{60 \mathrm{~s}}\right|(\mathrm{W})(4-21)$

The heat energy carried away from tank TB-5 by the water main's cooling water can be expressed by Equation (4-22)

$\dot{Q}_{\mathrm{TB} 5(\mathrm{removed})}=1061.3\left(\mathrm{~kg} / \mathrm{m}^{3}\right) \times \mathrm{FL} 2(\mathrm{l} / \mathrm{min}) \times 3522(\mathrm{~J} / \mathrm{kg} . \mathrm{K}) \times\left[\mathrm{T}_{1}-\mathrm{T}_{39}\right](\mathrm{K}) \times\left|\frac{10^{-3} \mathrm{~m}^{3}}{l}\right| \times\left|\frac{1 \mathrm{~min}}{60 \mathrm{~s}}\right|(\mathrm{W})(4-22)$

The rate of heat energy stored in tank TB-5 can be expressed by Equation (4-23)

$\dot{Q}_{\mathrm{TB} 5 \text { (stored) }}=\dot{Q}_{\mathrm{TB} 5 \text { (supplied) }}-\dot{Q}_{\mathrm{TB} 5(\text { removed })}$

The total energy stored in tank TB-3 can be expresses as below:

$\mathrm{Q}_{\mathrm{TB} 5 \text { (total) }}=\int \frac{\dot{Q}_{T B 5(\text { stored })}}{60} \times d t$

The heat rejection rate by the outdoor fan coil can be expressed by Equation (4-25) as below:

$\dot{Q}_{\text {Fan-coil }}=1049.6\left(\mathrm{~kg} / \mathrm{m}^{3}\right) \times \mathrm{FL} 20(1 / \mathrm{min}) \times 3599(\mathrm{~J} / \mathrm{kg} . \mathrm{K}) \times\left[\mathrm{T}_{36}-\mathrm{T}_{41}\right](\mathrm{K}) \times\left|\frac{10^{-3} \mathrm{~m}^{3}}{l}\right| \times\left|\frac{1 \mathrm{~min}}{60 \mathrm{~s}}\right|$

The total energy rejected by the outdoor fan coil can be expresses as below:

$\mathrm{Q}_{\text {Fan-coil }}=\int \frac{\dot{Q}_{\text {Fan-coil }}}{60} \times d t$

$(\mathrm{kWh})$

For different combinations of fan-coil and DHW tanks, the rate of heat rejection and total heat rejection are listed in Table. 4.7. 
Table 4.7 Heat rejection rate and the total heat rejection for different combinations

\begin{tabular}{|c|c|c|}
\hline Combinations & $\begin{array}{l}\text { Heat rejection rate }(W) \text { by } \\
\text { ClimateWell }^{\circledR} \text { chiller }\end{array}$ & Total heat rejection (kWh) \\
\hline $\begin{array}{l}\text { Heat is rejected to three } \\
\text { tanks first and then to } \\
\text { the outdoor fan coil }\end{array}$ & $\begin{array}{c}\dot{Q}_{\text {total }}=\dot{Q}_{\mathrm{TB} 3 \text { (stored) }}+\dot{Q}_{\mathrm{TB} 4 \text { (stored) }} \\
+\dot{Q}_{\mathrm{TB} 5 \text { (stored) }}+\dot{Q}_{\text {Fan-coil }}\end{array}$ & $\begin{array}{l}\mathrm{Q}_{\text {total }}=\left[\int \frac{\dot{Q}_{T B 3}(\text { stored })}{60} \times d t\right]+\left[\int \frac{\dot{Q}_{T B 4(\text { stored })}}{60} \times\right. \\
d t]+\left[\int \frac{\dot{Q}_{T B 5(\text { stored })}}{60} \times d t\right]+\left[\int \frac{\dot{Q}_{F a n-\text { coil }}}{60} \times d t\right]\end{array}$ \\
\hline $\begin{array}{l}\text { Heat is rejected to fan } \\
\text { coil first and then to the } \\
\text { three tanks }\end{array}$ & $\begin{array}{l}\dot{Q}_{\text {total }}=\dot{Q}_{\mathrm{TB} 3 \text { (stored) }}+\dot{Q}_{\mathrm{TB} 4 \text { (stored) }} \\
\quad+\dot{Q}_{\mathrm{TB} 5 \text { (stored) }}+\dot{Q}_{\text {Fan-coil }}\end{array}$ & $\begin{array}{l}\mathrm{Q}_{\text {total }}=\left[\int \frac{\dot{Q}_{T B 3(\text { stored })}}{60} \times d t\right]+\left[\int \frac{\dot{Q}_{T B 4(\text { stored })}}{60} \times\right. \\
d t]+\left[\int \frac{\dot{Q}_{T B 5(\text { stored })}}{60} \times d t\right]+\left[\int \frac{\dot{Q}_{\text {Fan-coil }}}{60} \times d t\right]\end{array}$ \\
\hline $\begin{array}{l}\text { Heat is rejected to three } \\
\text { tanks only }\end{array}$ & $\begin{array}{c}\dot{Q}_{\text {total }=} \dot{Q}_{\mathrm{TB} 3 \text { (stored) }}+\dot{Q}_{\mathrm{TB} 4 \text { (stored) }} \\
+\dot{Q}_{\mathrm{TB} 5 \text { (stored) }}\end{array}$ & $\begin{array}{l}\mathrm{Q}_{\text {total }}=\left[\int \frac{\dot{Q}_{T B 3}(\text { stored })}{60} \times d t\right]+\left[\int \frac{\left.\dot{Q}_{T B 4} \text { (stored }\right)}{60} \times\right. \\
d t]+\left[\int \frac{\dot{Q}_{T B 5(\text { stored })}}{60} \times d t\right]\end{array}$ \\
\hline $\begin{array}{l}\text { Heat is rejected to fan } \\
\text { coil only }\end{array}$ & $\dot{Q}_{\text {total }}=\dot{Q}_{\text {Fan-coil }}$ & $\mathrm{Q}_{\text {total }}=\int \frac{\dot{Q}_{\text {Fan-coil }}}{60} \times d t$ \\
\hline $\begin{array}{l}\text { Heat is rejected to tank } \\
\text { TB-3 only }\end{array}$ & $\dot{Q}_{\text {total }}=\dot{Q}_{\mathrm{TB} 3}$ & $\mathrm{Q}_{\text {total }}=\int \frac{\dot{Q}_{T B 3}}{60} \times d t$ \\
\hline $\begin{array}{l}\text { Heat is rejected to tank } \\
\text { TB-3 and then to fan } \\
\text { coil }\end{array}$ & $\dot{Q}_{\text {total }}=\dot{Q}_{\mathrm{TB} 3}+\dot{Q}_{\text {Fan-coil }}$ & $\begin{array}{l}\mathrm{Q}_{\text {total }}=\left[\int \frac{\dot{Q}_{T B 3(\text { stored })}}{60} \times d t\right]+\left[\int \frac{\dot{Q}_{\text {Fan-coil }}}{60} \times\right. \\
d t]\end{array}$ \\
\hline $\begin{array}{l}\text { Heat is rejected to fan } \\
\text { coil first and then to } \\
\text { tank TB-3 }\end{array}$ & $\dot{Q}_{\text {total }}=\dot{Q}_{\mathrm{TB} 3}+\dot{Q}_{\text {Fan-coil }}$ & $\begin{array}{l}\mathrm{Q}_{\text {total }}=\left[\int \frac{\dot{Q}_{T B 3(\text { stored })}}{60} \times d t\right]+\left[\int \frac{\dot{Q}_{\text {Fan-coil }}}{60} \times\right. \\
d t]\end{array}$ \\
\hline
\end{tabular}




\section{Summary:}

The ClimateWell ${ }^{\circledR}$ chiller rejects heat in both charging and discharge cycles. The charging time and rate depends on the heat removal rate from the chiller. Also, rate of cooling effect produced by the chiller depends on the efficient removal of the rejected heat. So, it is important to design an efficient heat rejection system that is capable of removing the entirety of the rejected heat from the chiller. The overall efficiency of the tri-generation system largely depends on proper utilization of waste heat. This also reduces the running cost associated with the tri-generation system. This project focused on the utilization of waste heat in preheating DHW. Waste heat can also be stored in boreholes for seasonal storage. 


\section{Chapter-5}

\section{Data Analysis}

In this chapter, experimental results of the residential tri-generation system will be discussed. Analysis of energy consumption, generation and energy storage are also incorporated in this chapter. This chapter also includes experimental results related to the charging and discharging behaviour of the ClimateWell ${ }^{\circledR}$ chiller.

As discussed in Chapter 4, the experimental work was carried out at House-B of the TRCA. No permanent occupant lived in the house during the experimentation period. However, the house was opened for the public to visit. As the experiment was carried out during the beginning of the winter season (October-November), create artificial cooling demand, the house was heated up through the in-floor heating system by the ground source heat pump (GSHP) that maintained an indoor temperature of around $24^{\circ} \mathrm{C}$. Several test runs were carried out after commissioning the tri-generation system. Several charge and discharge tests were carried out during the months of October and November.

\subsection{Charging Behaviour of the ClimateWell ${ }^{\circledR}$ Chiller}

The unique feature of the ClimateWell ${ }^{\circledR}$ chiller is its ability to store thermal energy which can be extracted as a form of cooling effects afterwards. In this residential tri-generation project, a CHP unit was used as the thermal source to charge the ClimateWell ${ }^{\circledR}$ chiller. As discussed in Chapter 3, during the charging period, the RSP and CHS valve of the relevant barrel remains open. The RSP valve allows the high temperature working fluid to enter into the reactor to start the desorption process. During the desorption process, released water vapour enters to the condenser and releases the condensation energy. The CHS valve allows cooling fluid to circulate in the condenser to remove the condensation energy. Figure 5.1 shows the state of valves (SOV) of the ClimateWell ${ }^{\circledR}$ chiller during a charging experimentation period of 550 minutes that took place on $12^{\text {th }}$ of November, 2012. The experiment started on November $12^{\text {th }}, 2012$ at 12:48 AM and finished at 9:58 PM. In Figure 5.1, the $\mathrm{x}$-axis represents the experimental time in minutes and the $y$-axis represents SOV. SOV value 1 indicates that the relevant valve is open and 0 represents the valve is closed. During the experiment, the chiller was operated in normal mode which allows 
charging one barrel at a time. As there was no cooling call from the house thermostat, so BarrelB first started to charge and after that it swapped and Barrel-A started to charge. From Figure 5.1 (a), it can be noted that the charging cycle of Barrel-B was almost 290 minutes long and during that period both the RSP and the CHS valve of Barrel-B remained opened. At the end of the charging cycle of Barrel-B, the chiller swapped to Barrel-A and Barrel-A started to charge. The charging cycle of Barrel-A was almost 250 minutes long as shown in Figure 5.1 (b) during which both the RSP and CHS valves remained open.

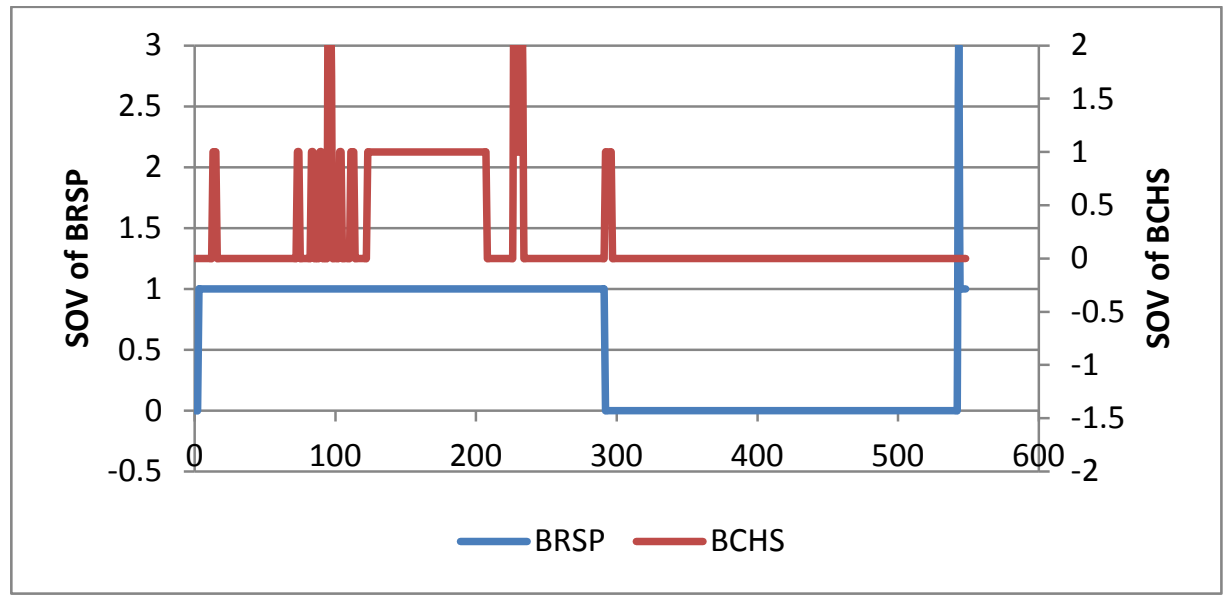

(a)

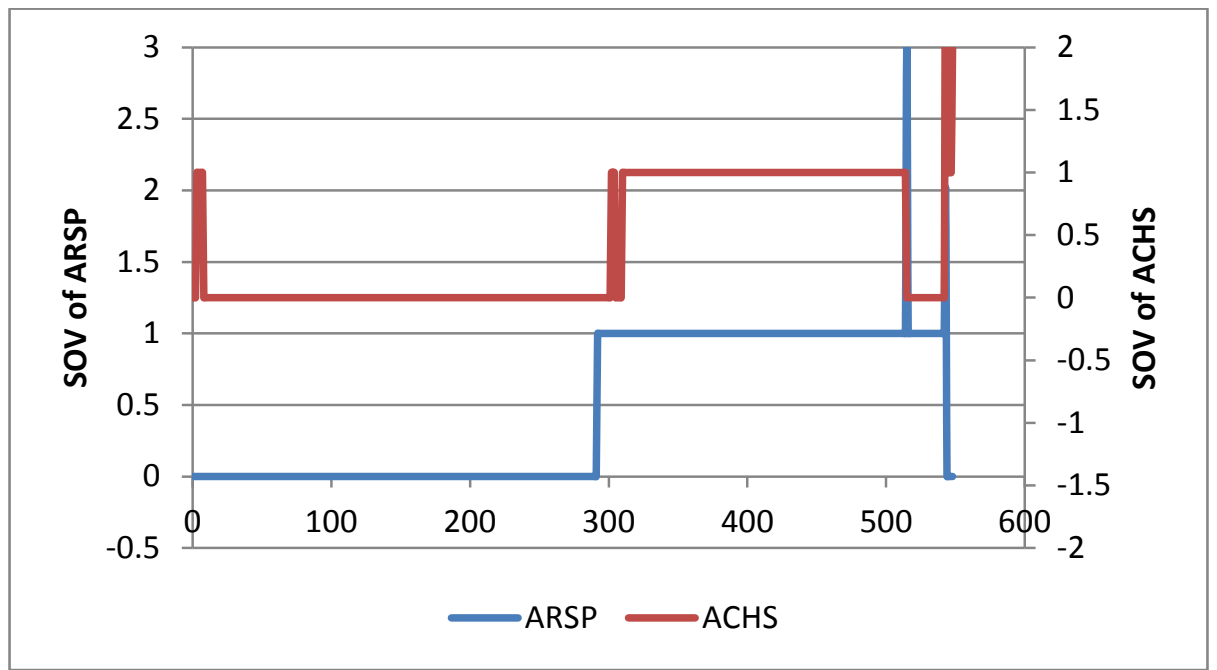

(b)

Figure 5.1 (a) SOC vs. time for Barrel-B (b) SOC vs. time for Barrel-A 
Figure 5.2 and Figure 5.3 show the temperature and the flow rate data with respect to time that was collected from different sensors during the charging cycle of both Barrel-B and Barrel-A. From Figure 5.2, it is observed that the supply temperature (T32) of the working fluid from the CHP unit reached to $90-95^{\circ} \mathrm{C}$ during the charging period. As shown in Figure 5.3, flow rate (FL17) of the working fluid in the charging circuit was within the range of 12-13 1/min. Due to the low flow rate, heat transfer rate from the CHP was low as well. The return temperature (T31) of the working fluid from the chiller to the CHP was only about $10^{\circ} \mathrm{C}$ lower than the supply temperature. Due to the low heat transfer rate from the CHP unit, the supply temperature (T32) quickly reached to the set point temperature $\left(95^{\circ} \mathrm{C}\right)$ which caused frequent on and off cycling.

From Figure 5.2, it is also noted that the heat rejection temperature (T34) from the chiller was within the range of $20-30^{\circ} \mathrm{C}$ which was almost $60-70^{\circ} \mathrm{C}$ lower than the supply temperature (T32). During the experiment, the chiller rejected heat to the DHW tanks and the return temperature (T41) of the working fluid from the heat sink to the chiller was about $15-18^{\circ} \mathrm{C}$. As shown in Figure 5.3, during the experiment, the flow rate (FL20) in the heat rejection circuit was maintained at a steady rate of $15 \mathrm{l} / \mathrm{min}$.

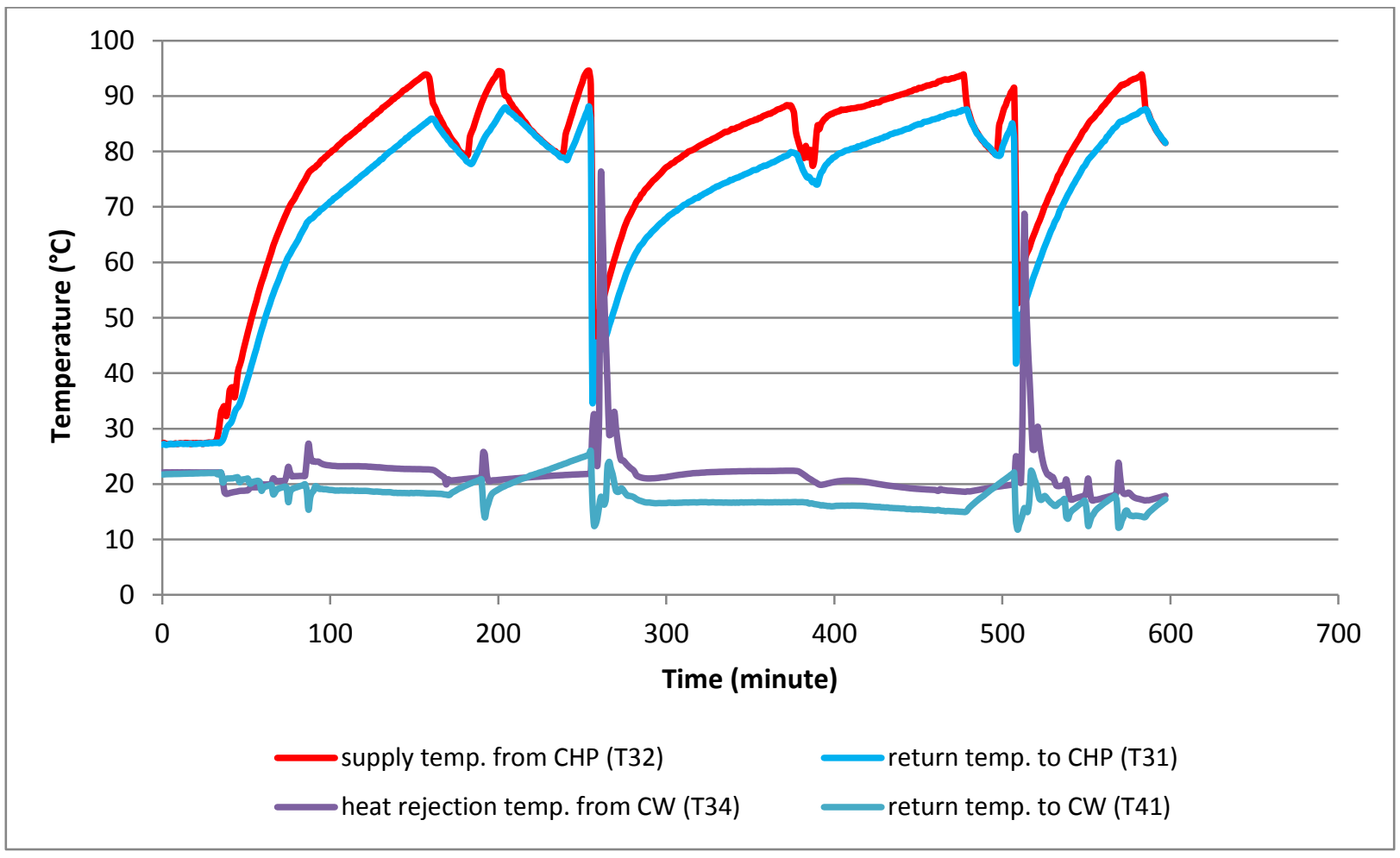

Figure 5.2 Temperature vs. time data of different sensors 


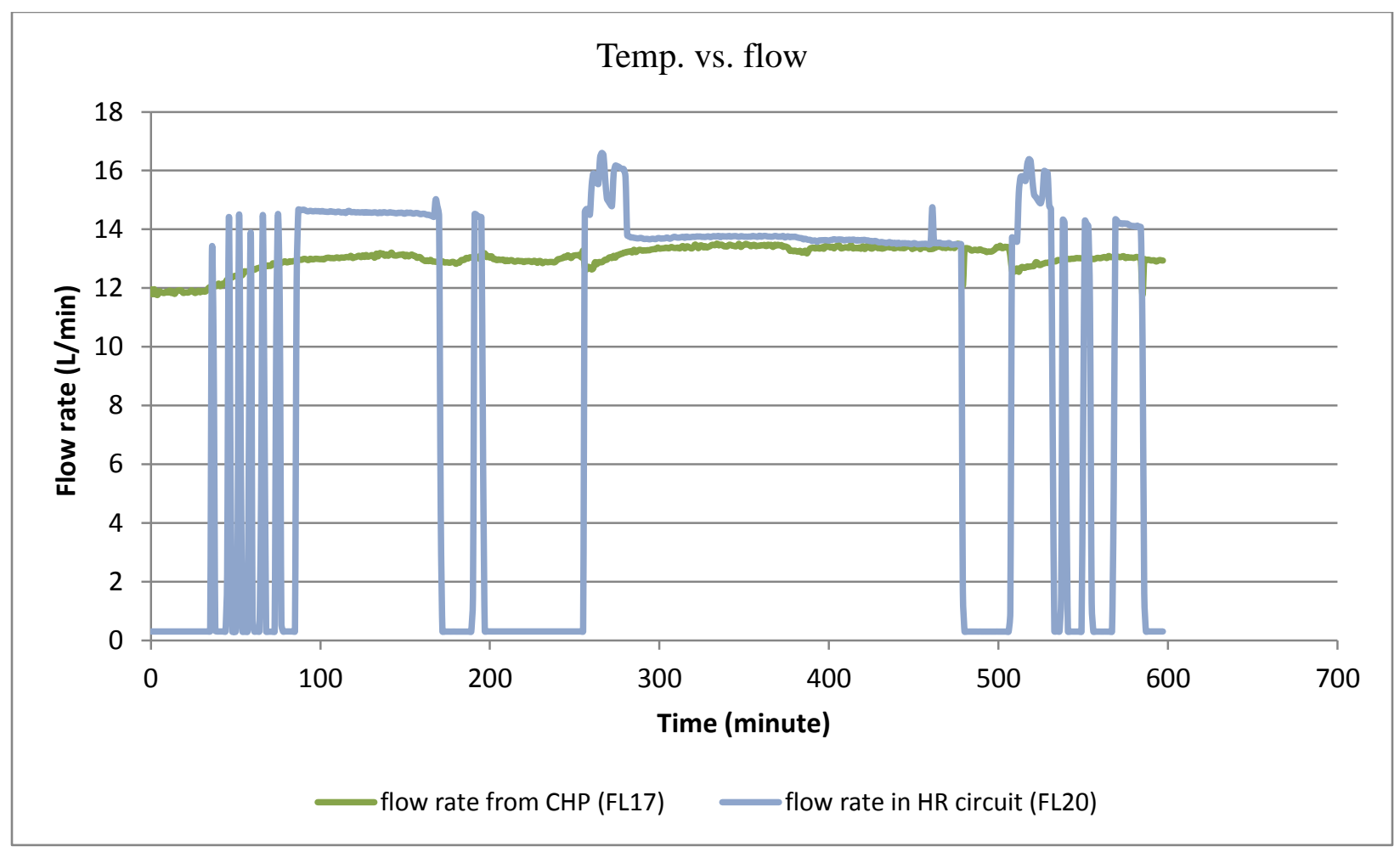

Figure 5.3 flow rate vs. time data of different sensors

Figure 5.4 shows the heat transfer rate $\left(\dot{Q}_{\text {Thermal }}\right)$ from the CHP with respect to time during the charging cycle. From Figure 5.4, it is observed that at the starting of the charging cycle, the heat transfer rate $\left(\dot{Q}_{\text {Thermal }}\right)$ of the CHP unit was low and it quickly ramped up to $8 \mathrm{~kW}$ within 20 minutes. The CHP was operated in maximum mode which allows up to $12 \mathrm{~kW}$ of heat transfer. Due to frequent on and off cycling of the CHP unit, the heat transfer rate was not steady rather it was fluctuating. It is also observed that the heat transfer rate from the CHP unit started to fall down towards the end of the charging cycle.

Figure 5.5 shows the heat rejection rate $\left(\dot{Q}_{\text {Rejection }}\right)$ and the heat storage rate $\left(\dot{Q}_{\text {stored }}\right)$ with respect to time during the charging cycle. It is observed that at the start of the charging cycle, the heat rejection rate was quite low and the heat storage rate was high which means that at the beginning of the charging cycle, a substantial amount of thermal energy is required to start the desorption process. Also it is noted that at the end of the charging cycle, both the heat rejection rate and heat storage rate dropped. Experimental data shows that during the charging cycle, the heat rejection rate was within the range of $3-6 \mathrm{~kW}$ and heat storage rate was about $2-3.5 \mathrm{~kW}$. It is noted that 
both the heat rejection rate and the heat storage rate were unsteady and this was due to the frequent on and off cycling of the CHP unit due to overheating.

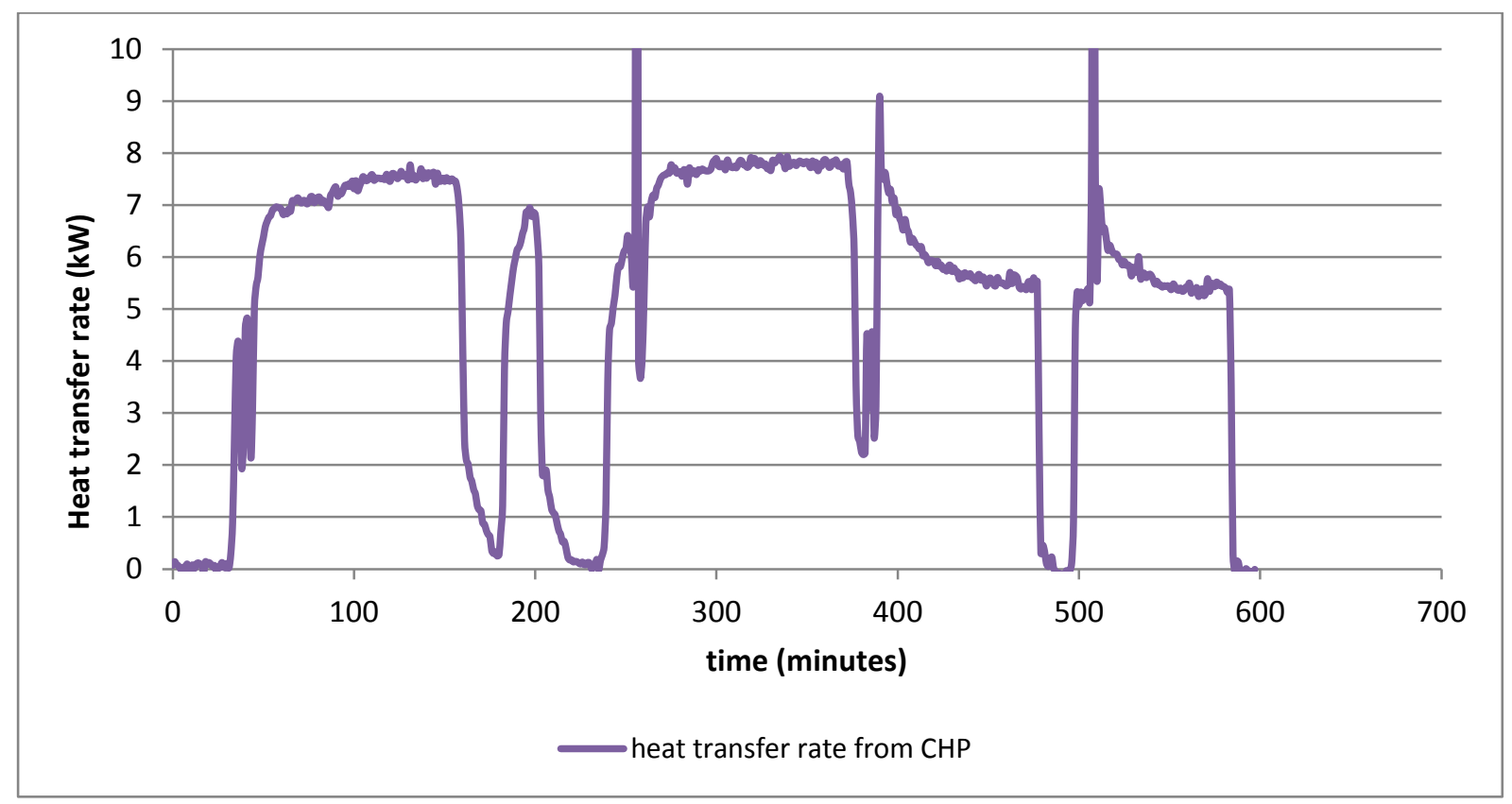

Figure 5.4 Heat transfer rate from CHP vs. time during the charging cycle

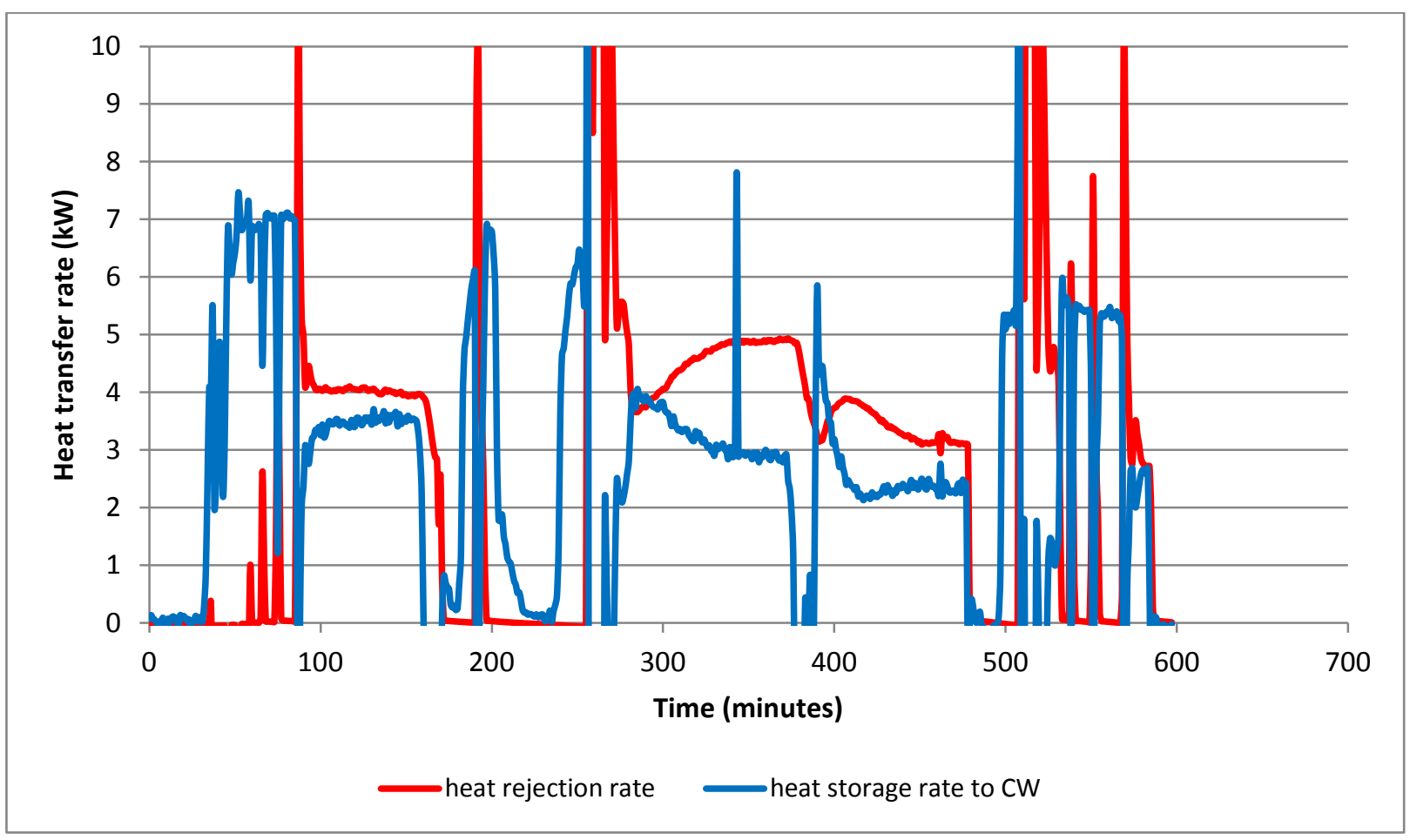

Figure 5.5 Heat rejection rate and heat storage rate vs. time during the charging cycle 
Table 5.1 shows the conservation of energy during the charging cycle. From Table 5.1, it is observed that during the charging cycle, Barrel-B stored $25.18 \%$ of the supplied energy and Barrel-A stored almost $19.0 \%$ of the supplied energy. Theoretically during the charging cycle, the barrels usually store 30\% of the supplied energy (ClimateWell, 2008). However, the storage capacity depends on the heat source temperature, charging power and vacuum level of the barrels.

\section{Table 5.1 Energy conservation during charging cycle}

\begin{tabular}{|c|c|c|c|c|c|}
\hline Barrel & $\begin{array}{c}\mathbf{Q}_{\text {Thermal }} \\
(\mathbf{k W h})\end{array}$ & $\begin{array}{c}\mathbf{Q}_{\text {Rejected }} \\
(\mathbf{k W h})\end{array}$ & $\begin{array}{c}\mathbf{Q}_{\text {stored }} \\
(\mathbf{k W h})\end{array}$ & $\begin{array}{c}\text { \% Energy } \\
\text { rejected }\end{array}$ & $\begin{array}{c}\text { \% Energy } \\
\text { stored }\end{array}$ \\
\hline $\mathrm{B}$ & 28.59 & 21.39 & 7.20 & 74.82 & 25.18 \\
\hline $\mathrm{A}$ & 24.91 & 20.18 & 4.73 & 81.00 & 19.00 \\
\hline
\end{tabular}

As shown in Table 5.1, during the charging cycle, Barrel-B rejected almost $75 \%$ of the supplied energy and Barrel-A rejected about $81 \%$ of the supplied energy. This indicates that the vacuum level of the two barrels were not in the same level. One of the main objectives of this research was to find efficient ways to utilize the substantial amount of energy that the ClimateWell ${ }^{\circledR}$ chiller rejects during both the charge and discharge cycle. As per the discussion in Chapter 3, multiple DHW tanks were used in series in this project to utilize the rejected energy. Figure 5.6 shows the temperature of the working fluid at different points of the heat rejection circuit. In Figure 5.6, T34 represents the temperature of the working fluid from the ClimateWell ${ }^{\circledR}$ chiller entering to the DHW tanks and T41 represents the return temperature of the working fluid back to the chiller after passing through the three DHW tanks. T35 and T36 represent the temperature of the working fluid after it had rejected heat to tank TB-3 and TB-4, respectively. It is noted that the temperature of the working fluid dropped only about $1-2^{\circ} \mathrm{C}$ after passing through the first tank (TB-3). This is because; only the top heat exchanger of the tank TB-3 was used for heat rejection during the experiment. The temperature of the working fluid dropped about $2-3^{\circ} \mathrm{C}$ after rejecting the heat to the second tank (TB-4) and the maximum temperature drop (about $5-6^{\circ} \mathrm{C}$ ) occurred across the third tank (TB-5). Total $\Delta \mathrm{T}$ in the heat rejection circuit was about $10^{\circ} \mathrm{C}$. This is because the water main's cold water first enters in tank TB-5 and so maximum portion of the rejected heat is removed by this tank. As shown in Figure 5.6, temperature (T1) of the main's cold water was around $10-11^{\circ} \mathrm{C}$ and flow rate (FL2) was around $61 /$ min during the experiment 
and both the temperature and flow rate were almost constant. It is also observed from Figure 5.6 that, the sensors read a high value at the point when the valve position changes indicating a barrel switch.

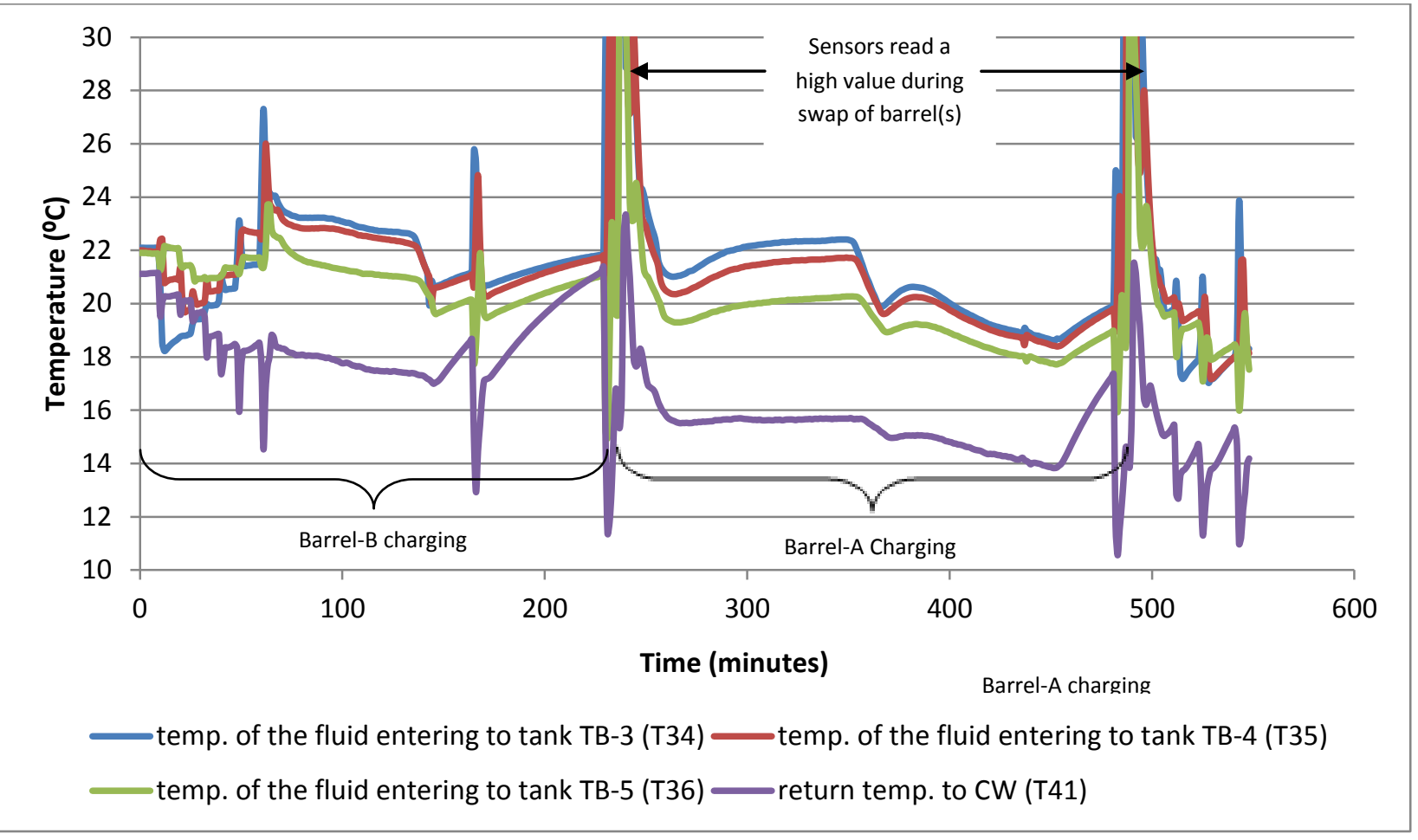

Figure 5.6 Temperature of the working fluid at different points of the heat rejection circuit

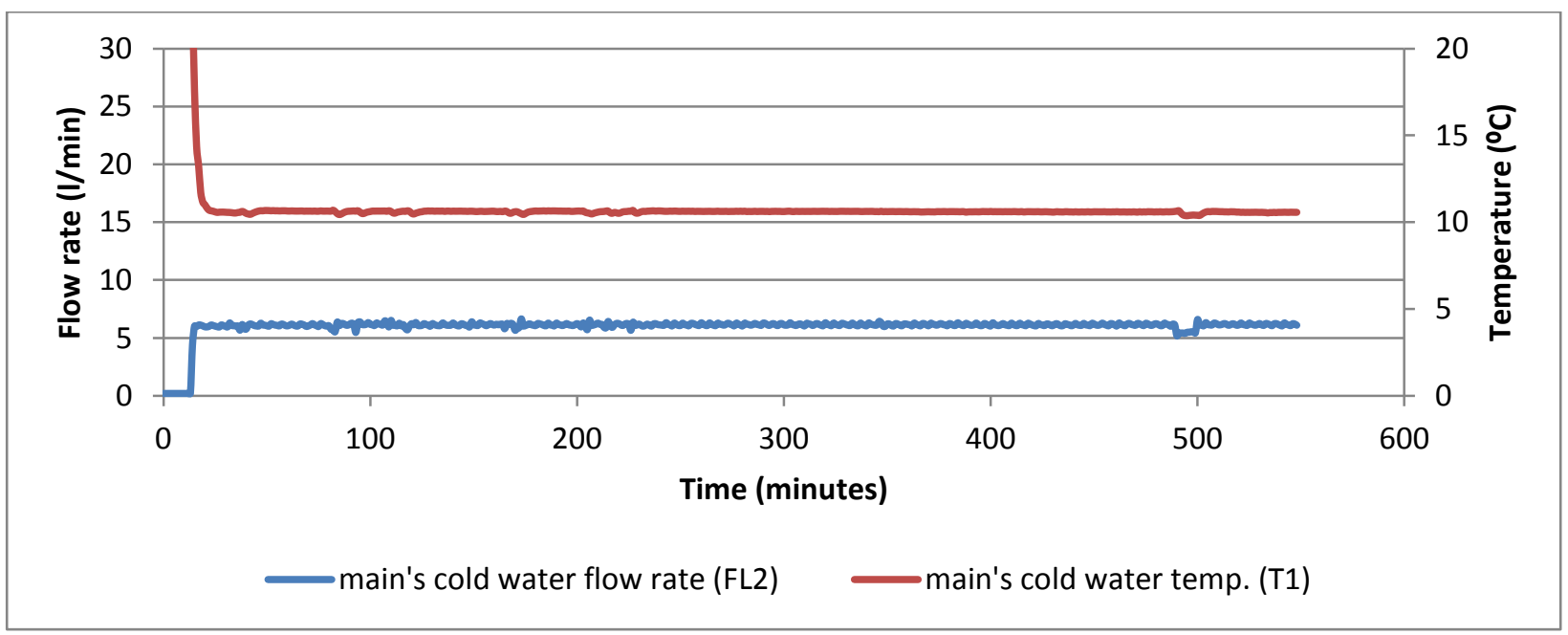

Figure 5.7 Temperature and flow rate of main's cold water 
Figure 5.8 shows the temperature of the water inside the three DHW tanks during the experiment. In Figure 5.8, T1 represents temperature of the main's cold water and at the start of the experiment; all the three DHW tanks were filled with the main's cold water. T23, T40 and T39 represent the temperature of water inside tanks TB-3, TB-4 and TB-5, respectively. Utilizing the rejected heat, the three DHW tanks worked as a cascade storage system where tank TB-3 contained the highest temperature water, TB-4 contained mid-temperature water and tank TB-5 contained the lowest temperature water. High temperature water from tank TB-3 is supplied to the time of use (TOU) tank where it is heated up to $50-60^{\circ} \mathrm{C}$ by means of electricity before supplying it for domestic purposes. Preheating the water by utilizing the rejected heat from the ClimateWell $^{\circledR}$ chiller reduces the energy consumption of the house associated with DHW production and also increases the overall efficiency of the tri-generation system. Details of energy conservation during the charging cycle are summarized in Table 5.2.

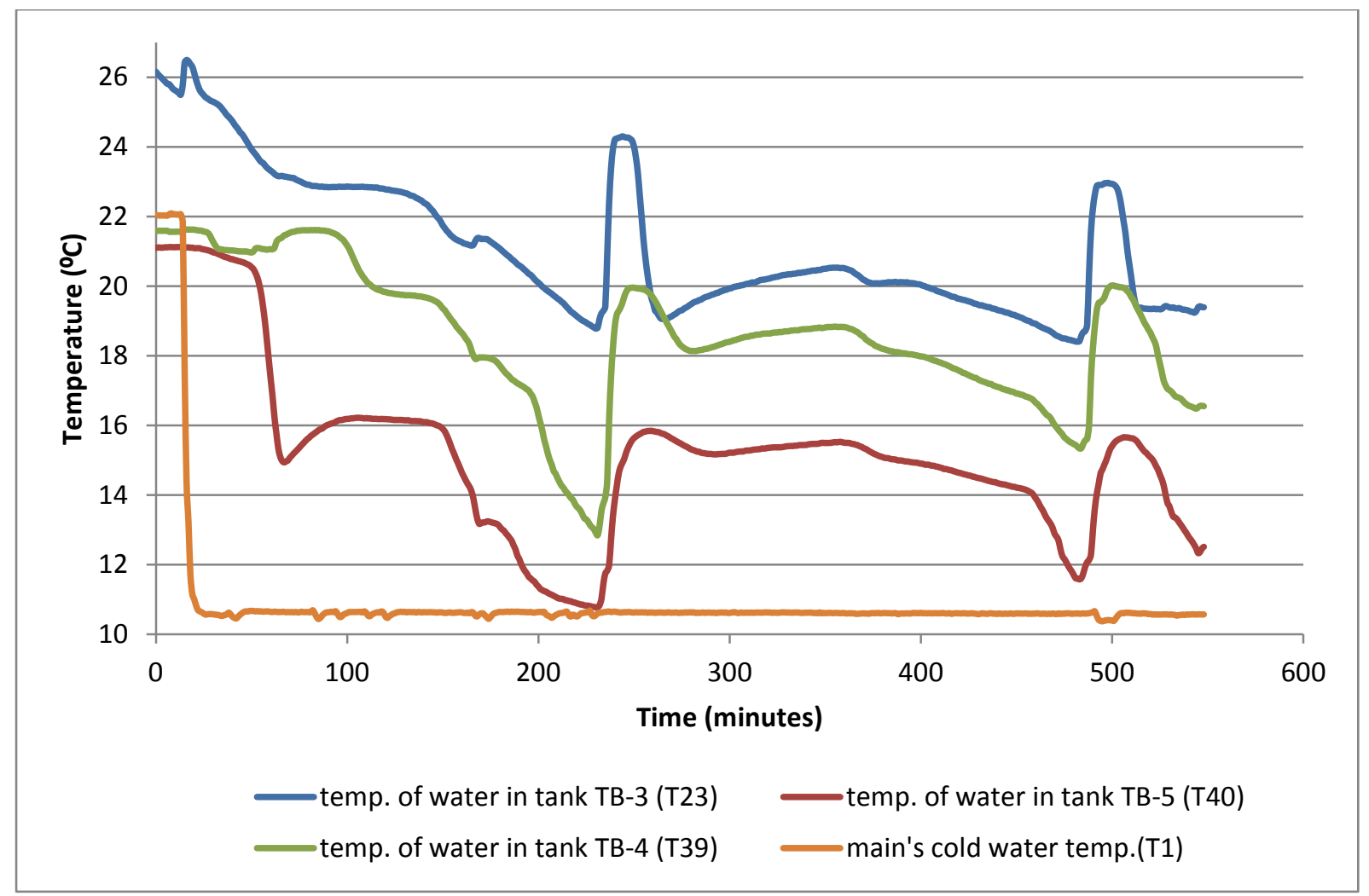

Figure 5.8 Temperature of water in the three DHW tanks during the charging cycle 
Table 5.2 Details energy conservation during charging cycle

\begin{tabular}{|c|c|c|c|c|c|c|c|c|c|c|}
\hline \multirow[t]{2}{*}{ Barrel } & \multirow{2}{*}{$\begin{array}{c}\text { Natural } \\
\text { Gas } \\
\text { consumption } \\
(\mathbf{k W h})\end{array}$} & \multirow{2}{*}{$\begin{array}{c}\mathbf{Q}_{\text {Thermal }} \\
\text { produced } \\
\text { by CHP } \\
(\mathbf{k W h})\end{array}$} & \multirow{2}{*}{$\begin{array}{c}\text { Thermal } \\
\text { efficiency } \\
\text { of CHP } \\
(\%)\end{array}$} & \multirow{2}{*}{$\begin{array}{c}\text { Q Rejected } \text { by } \\
\text { ClimateWell }^{\circledR} \\
(\mathbf{k W h})\end{array}$} & \multicolumn{3}{|c|}{$\begin{array}{c}\text { Rejected energy removed } \\
(\mathrm{kWh})\end{array}$} & \multicolumn{3}{|c|}{$\begin{array}{c}\text { \% removal of rejected } \\
\text { energy }\end{array}$} \\
\hline & & & & & $\begin{array}{c}\text { by tank } \\
\text { TB-5 } \\
(\mathbf{k W h}) \\
\end{array}$ & $\begin{array}{c}\text { by tank } \\
\text { TB-4 } \\
\text { (kWh) }\end{array}$ & $\begin{array}{c}\text { by tank } \\
\text { TB-3 } \\
\text { (kWh) }\end{array}$ & $\begin{array}{c}\text { by tank } \\
\text { TB-5 } \\
(\%)\end{array}$ & $\begin{array}{c}\text { by tank } \\
\text { TB-4 } \\
(\%)\end{array}$ & $\begin{array}{c}\text { by tank } \\
\text { TB-3 } \\
(\%)\end{array}$ \\
\hline B & 40.00 & 28.59 & 71.50 & 21.39 & 9.07 & 6.74 & 5.62 & 42.38 & 31.52 & 26.03 \\
\hline $\mathbf{A}$ & 33.03 & 24.91 & 75.41 & 20.18 & 8.72 & 7.33 & 4.14 & 43.19 & 36.30 & 20.51 \\
\hline
\end{tabular}




\subsection{Discharge Behaviour of ClimateWell ${ }^{\circledR}$ Chiller}

During the charging cycle, the ClimateWell ${ }^{\circledR}$ chiller stores a portion of the supplied energy which produces the cooling effect afterwards. During the discharge cycle, the CAC valve of the relevent barrel is opened to start the discharge process. As vacuum pressure is maintained inside the barrel, so the water inside the condenser starts to evaporate as soon as the CAC valve is opened. During the discharge cycle, the CAC valve connects the condenser of the relevent barrel that is to be discharged with the space that is to be cooled. The water inside the condenser absorbs energy from the space and starts to evaporate. The evaporated water vapour then enters to reactor vessel where it rejects the condensation energy and gets absorbed by the unsaturated salts/crystals. The RHS valve of the respective barrel connects the reactor vessel with the heat sink to reject the condensation energy.

Figure 5.9 shows the SOV of Barrel-A during a discharge test of about 270 minutes. The discharge test started on October $17^{\text {th }}, 2012$ at 4:54 PM and finished after 270 minutes at 9:27 PM. From Figure 5.9, it is observed that during the discharge period, both the CAC and RHS valve of Barrel-A remained opened. It is also noted that the CHS valve opened 5-7 minutes after the CAC valve opened, which indicates that it takes 5-7 minutes to start the vaporization process of water in the condenser.

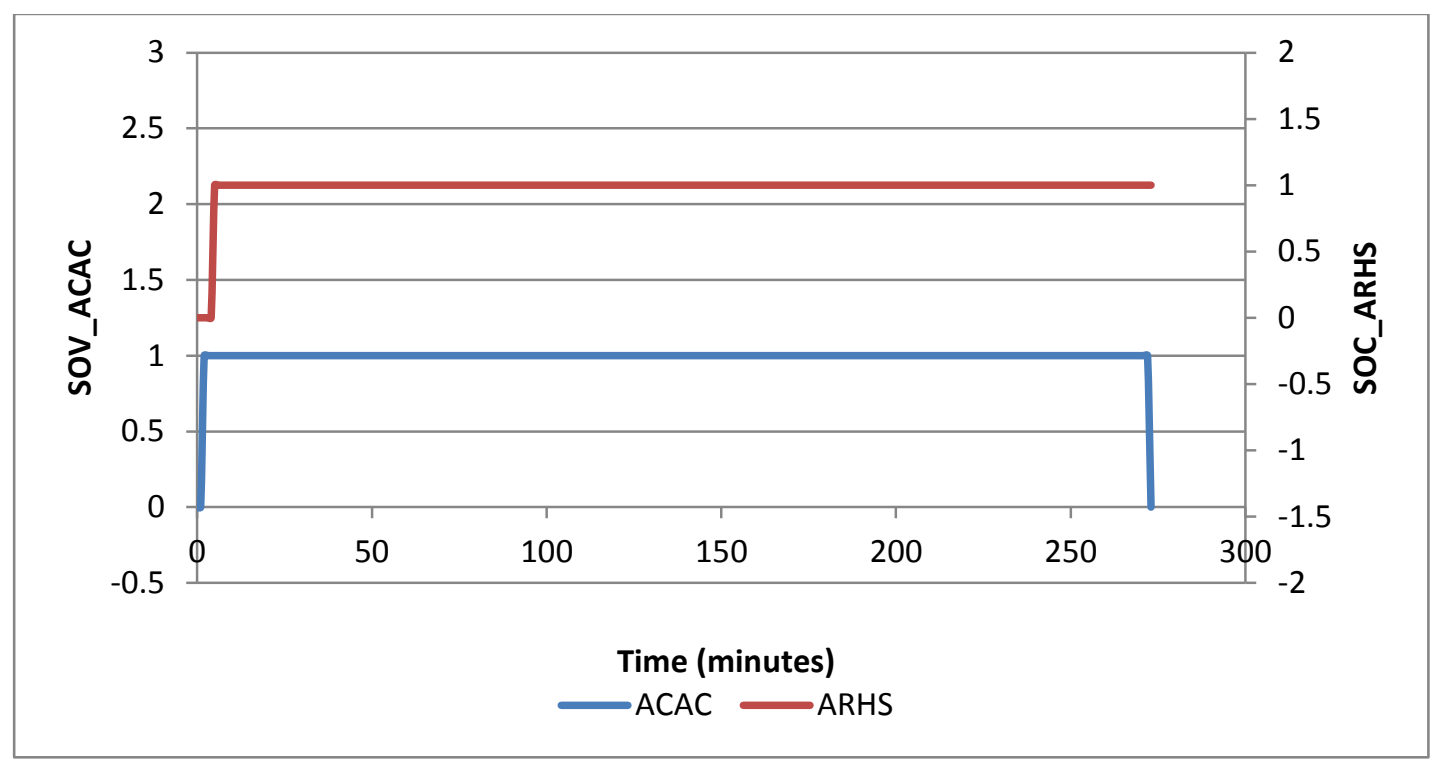

Figure 5.9 SOV vs. time for Barrel-A during discharge process 
Figure 5.10 shows the temperature data collected from different sensors during the discharge test of barrel-A. From Figure 5.10, it is noted that the temperature of the chilled water (T14) supplied from the ClimateWell ${ }^{\circledR}$ was within the range of $10-12^{\circ} \mathrm{C}$. Also it is noted that the chilled water temperature was lower at the starting of the discharge process and it went up to $15-16^{\circ} \mathrm{C}$ towards the finish of the discharge cycle. Although the manufacturer claims that the ClimateWell ${ }^{\circledR}$ chiller can deliver chilled water at a temperature of as low as $8^{\circ} \mathrm{C}$ (ClimateWell, 2009), during the experiment the lowest chilled water temperature experienced was $11^{\circ} \mathrm{C}$. During the experiment, the flow rate (FL8) in the chilled water circuit was maintained to $10.51 / \mathrm{min}$ and it was nearly steady. From Figure 5.10, it is also noted that the return temperature (T13) of the chilled water back to the ClimateWell ${ }^{\circledR}$ chiller after passing through the two fan coils was within the range of $15-16^{\circ} \mathrm{C}$ and it was around $3.5-4^{\circ} \mathrm{C}$ higher than the supply temperature. It is also observed that both the supply and the return temperature followed a similar pattern.

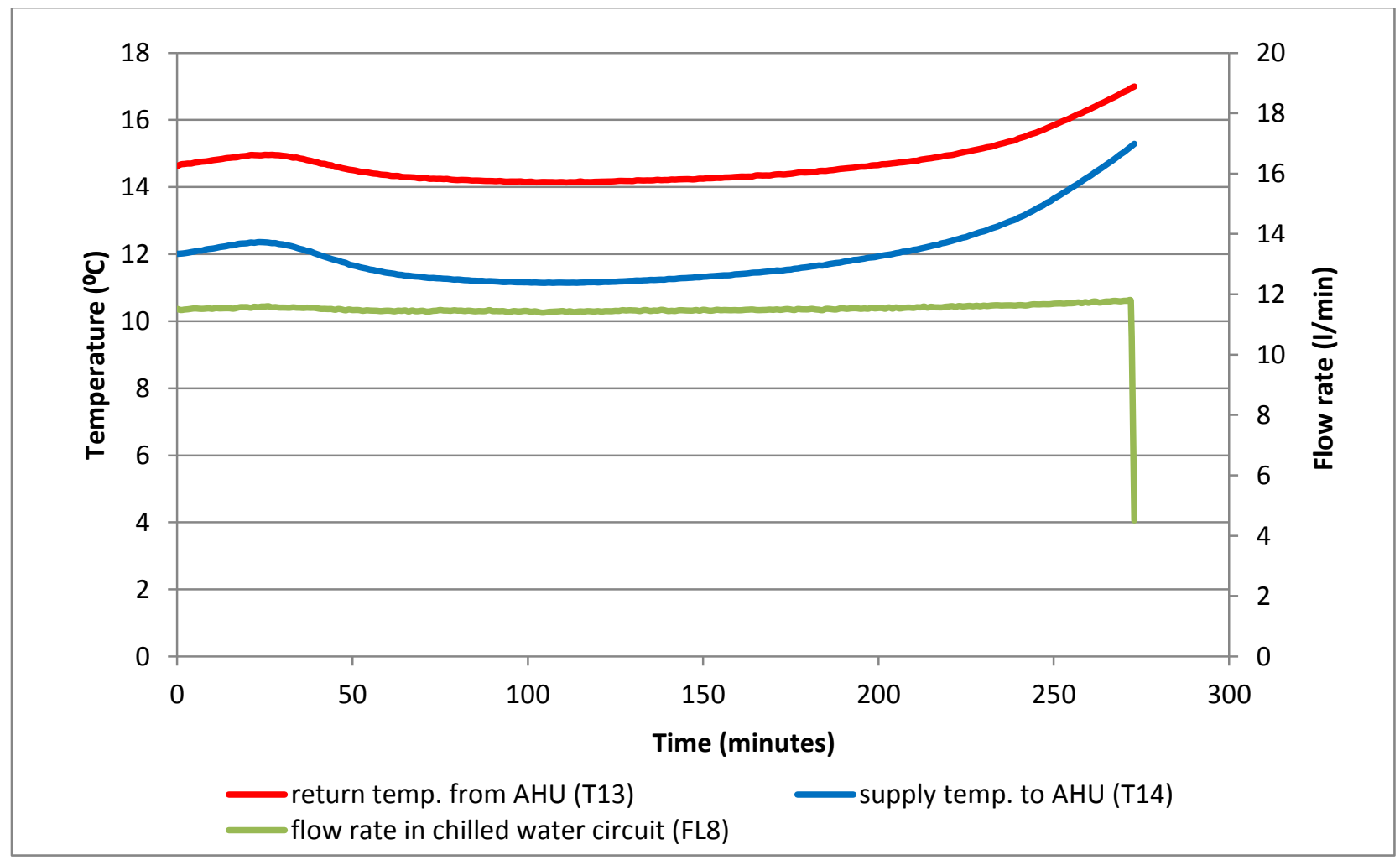

Figure 5.10 Temperature and flow rate vs. time of the chilled water

Figure 5.11 shows the cooling rate $\left(\dot{Q}_{\text {Discharge }}\right)$ supplied by the ClimateWell ${ }^{\circledR}$ chiller during discharge of Barrel-A. From Figure 5.11, it is observed that the cooling rate $\left(\dot{Q}_{\text {Discharge }}\right)$ was about 
$2.3 \mathrm{~kW}$ during the discharge cycle. The cooling rate was lower at the start and end of the cycle and other than that, the cooling rate was almost steady. Figure 5.12 shows the TRNSYS predicted cooling demand for House-B. From Figure 5.12, it is observed that the average cooling demand of the house is $2.25 \mathrm{~kW}$, while the peak cooling demand is $4.86 \mathrm{~kW}$. It can be concluded that each barrel is able to meet the average cooling demand, but to meet the peak cooling demand, both the barrels should be discharged at the same time.

According to the manufacturer, the cooling power of each barrel is nearly $3-3.5 \mathrm{~kW}$ (for a $100 \%$ charge level), which depends on the heat rejection temperature, charging level and vacuum level of the barrels. Cooling power varies with charge level and cooling power is higher for the higher charge level of the barrels.

According to the experimental data, the cooling power of Barrel-A is much lower than the manufacturer's claim for the $100 \%$ charge level. This is due to the lower thermal energy supplied by the CHP unit; the barrels were not fully $(100 \%)$ charged during the charging cycle. Also it is suggested to check the vacuum level of the barrels as the chiller is showing poor charging performance.

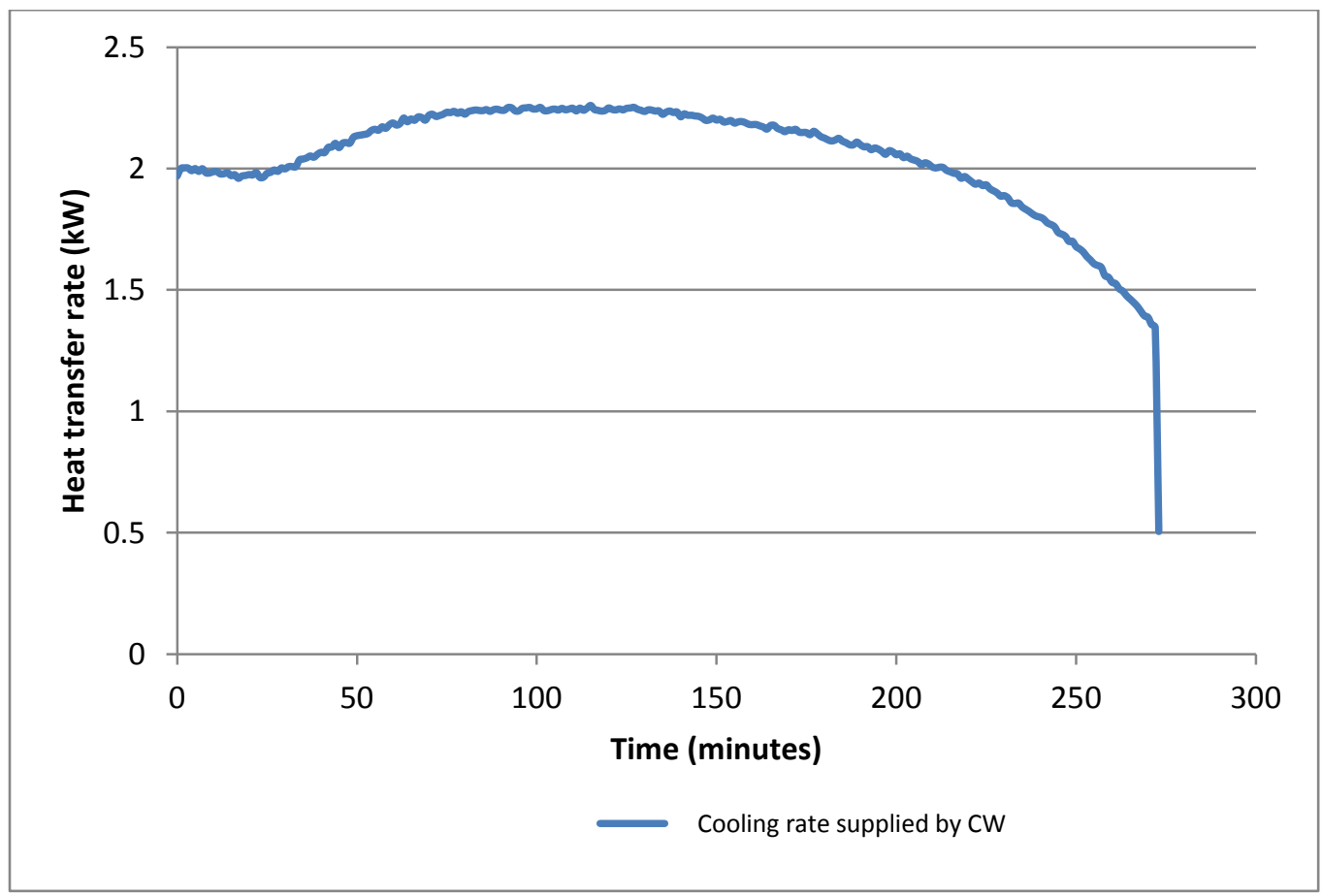

Figure 5.11 Cooling power vs. time for Barrel-A 


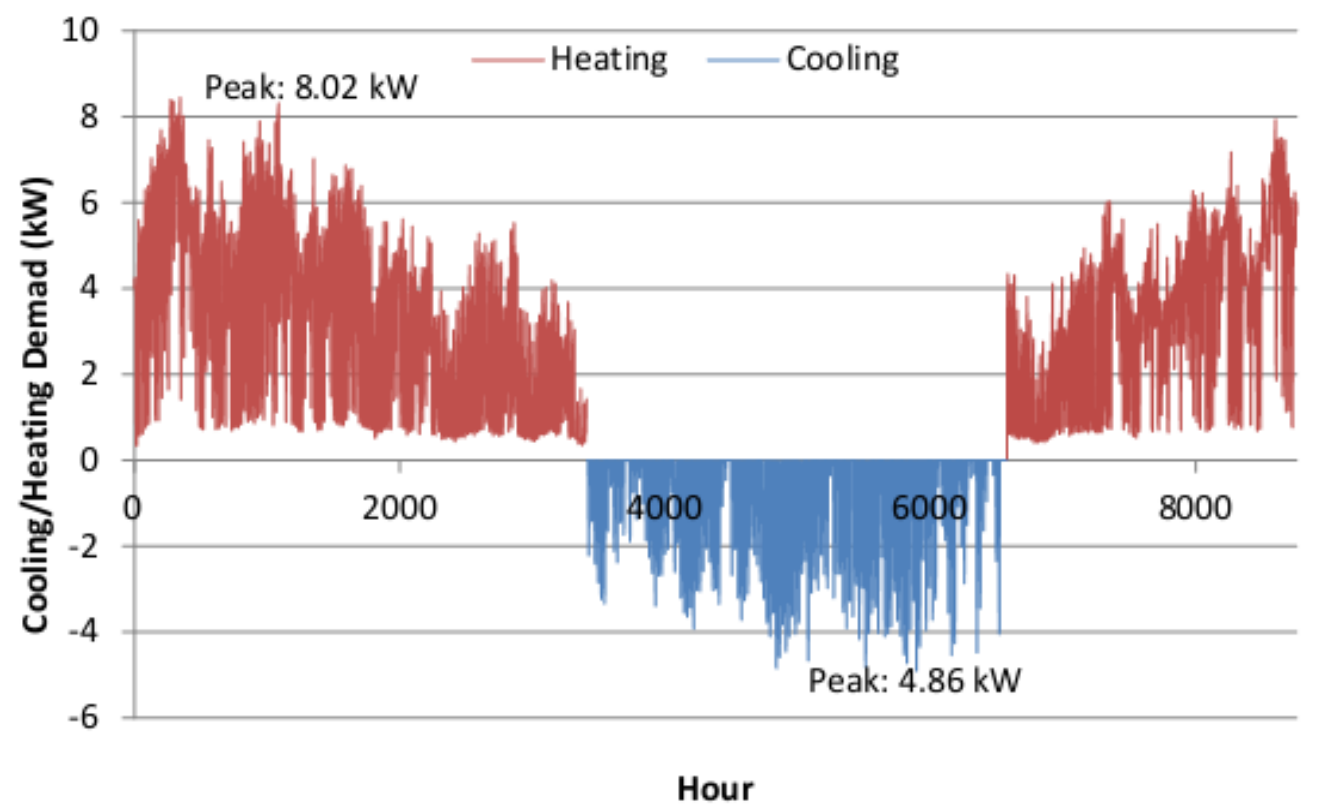

Figure 5.12 TRNSYS predicted cooling demand of House-B

Figure 5.13 shows the heat rejection temperature and the heat rejection rate with respect to time during the discharge cycle. From Figure 5.13, it is observed that the heat rejection temperature (T34) was within the range of $25-30^{\circ} \mathrm{C}$ during the discharge cycle and the combination of the three tanks dropped the heat rejection temperature about $4-5^{\circ} \mathrm{C}$. The return temperature of the working fluid (T41) back to the chiller was within the range of $15-20^{\circ} \mathrm{C}$. It is also noted that the heat rejection rate $\left(\dot{Q}_{\text {Rejection }}\right)$ was lower towards the end of the cycle. The average heat rejection rate during the discharge cycle was within $4-5 \mathrm{~kW}$. Figure 5.14 shows that throughout the discharge cycle, flow in the heat rejection circuit was almost steady and it was about 14-15 1/min. 


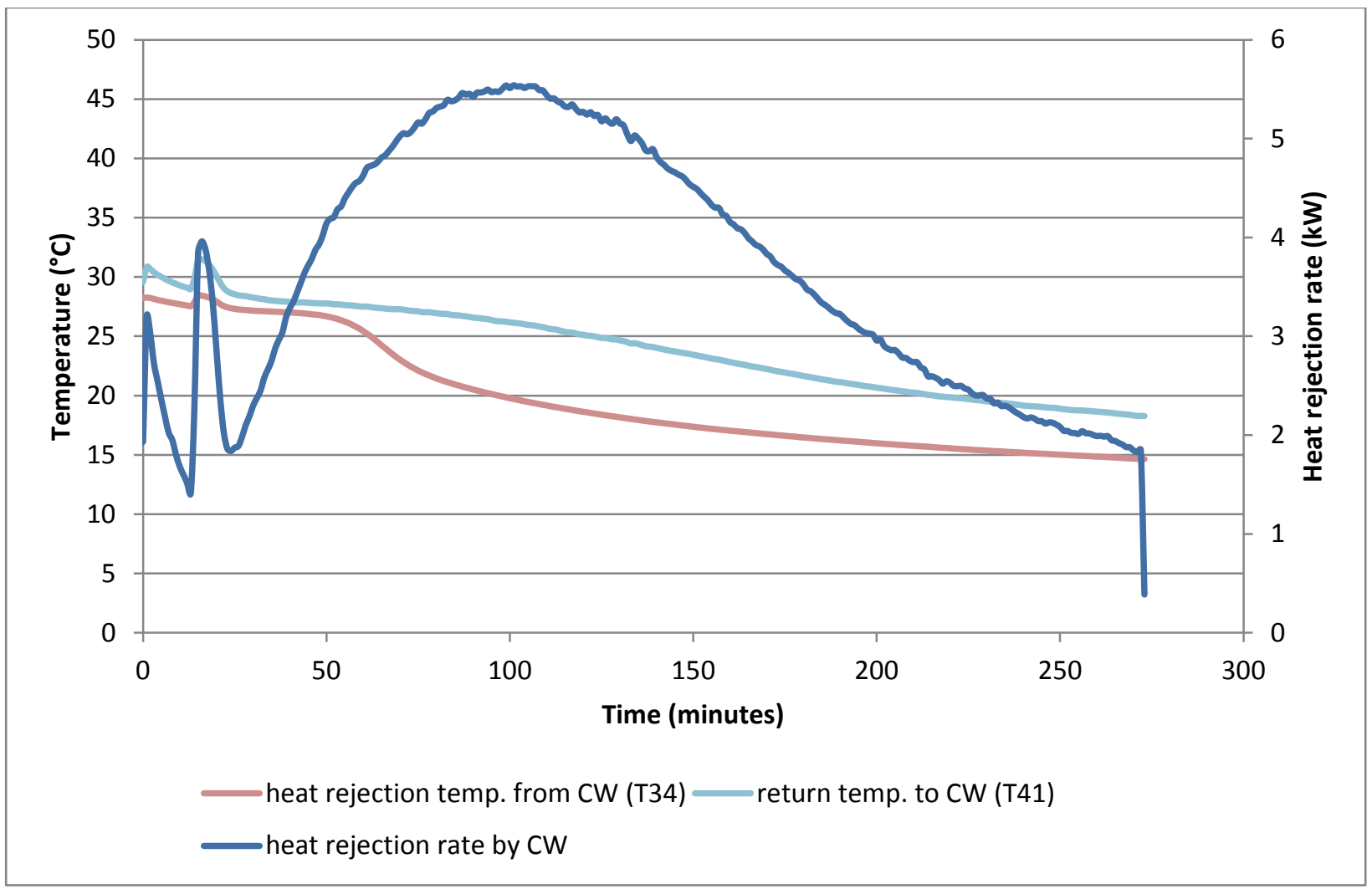

Figure 5.13 Temperature and heat rejection rate vs. time during the discharge cycle

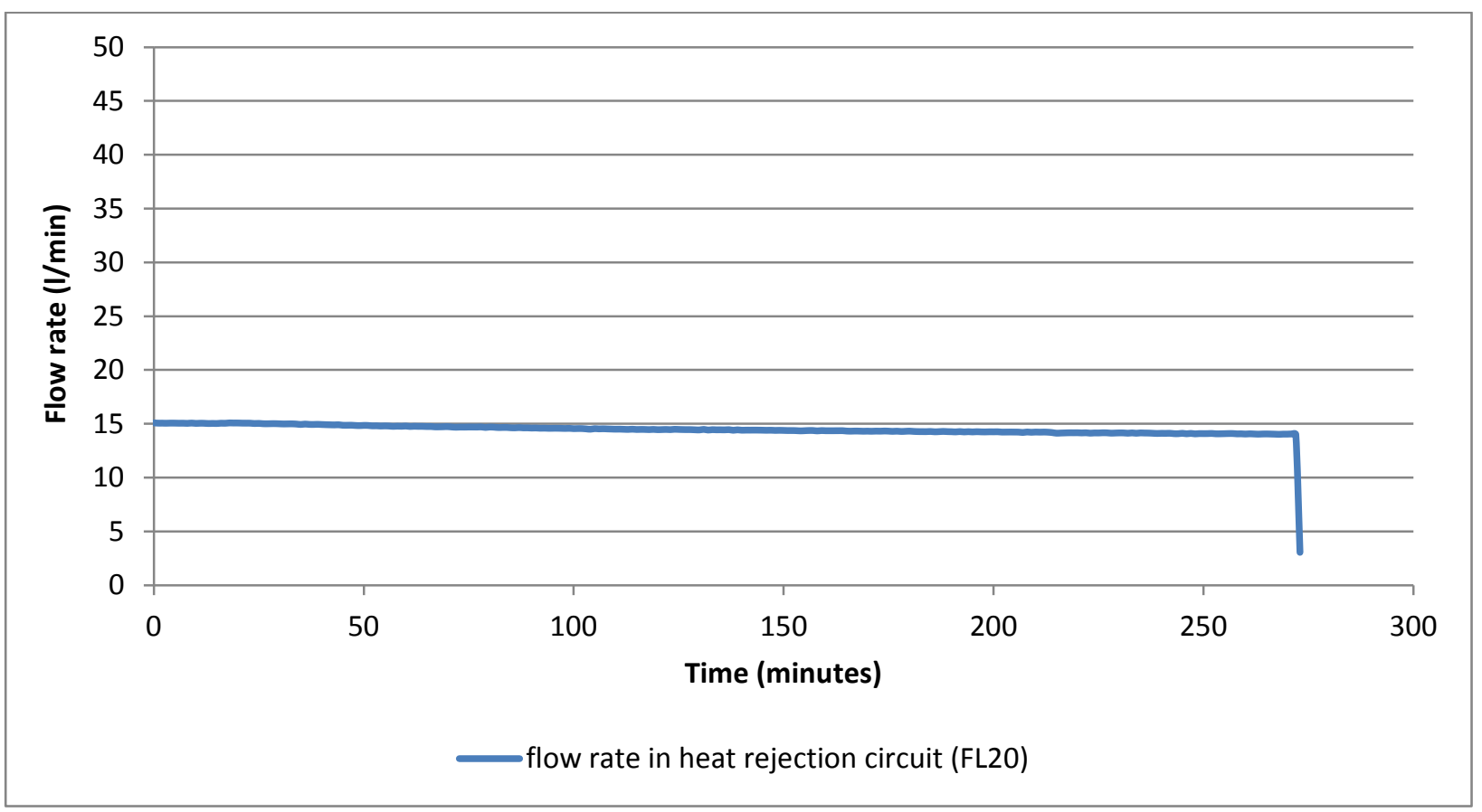

Figure 5.14 Flow rate vs. time in the heat rejection circuit 
The energy conservation during discharge cycle of Barrel-A is given in Table 5.3 as below.

Table 5.3 Energy conservation during discharge cycle

\begin{tabular}{|c|c|c|c|c|}
\hline Barrel & $\begin{array}{c}\text { Cooling effect } \\
\text { produced } \\
\dot{\boldsymbol{Q}}_{\text {Discharge, }}(\mathbf{k W h})\end{array}$ & $\begin{array}{c}\text { Heat rejection, } \\
\dot{\boldsymbol{Q}}_{\text {Rejection, }}, \mathbf{( k W h )}\end{array}$ & $\begin{array}{c}\text { Thermal energy } \\
\text { required to charge } \\
\text { the barrel } \dot{\boldsymbol{Q}}_{\text {Thermal }}, \\
\mathbf{( k W h )}\end{array}$ & $\boldsymbol{C O P}_{\text {Cooling }}$ \\
\hline $\mathrm{A}$ & 9.32 & 16.62 & 28.53 & 0.365 \\
\hline
\end{tabular}

From Table 5.3, it is observed that the COP of the chiller is about 0.365 . The theoretical COP of the TCA cycle is 0.68 (ClimateWell, 2008) and the manufacturer claims that a practical COP of the ClimateWell ${ }^{\circledR}$ chiller is within the range of 0.52-0.58. According to the experimental data, the COP of the chiller is much lower than the manufacture's claim and this is because the COP depends on the charging level and the charging temperature and so it was not be possible to fully (100\%) charge the barrels with the existing CHP unit.

It is also noted from Table 5.3 that during the discharge cycle the chiller rejects a substantial amount of thermal energy. As discussed in Section 5.1 of this chapter, this substantial amount of rejected energy can be utilized to preheat the DHW which reduces the energy consumption associated with the DHW production.

Based on the experimental data, a typical energy flow diagram for each barrel is shown in Figure 5.15 .

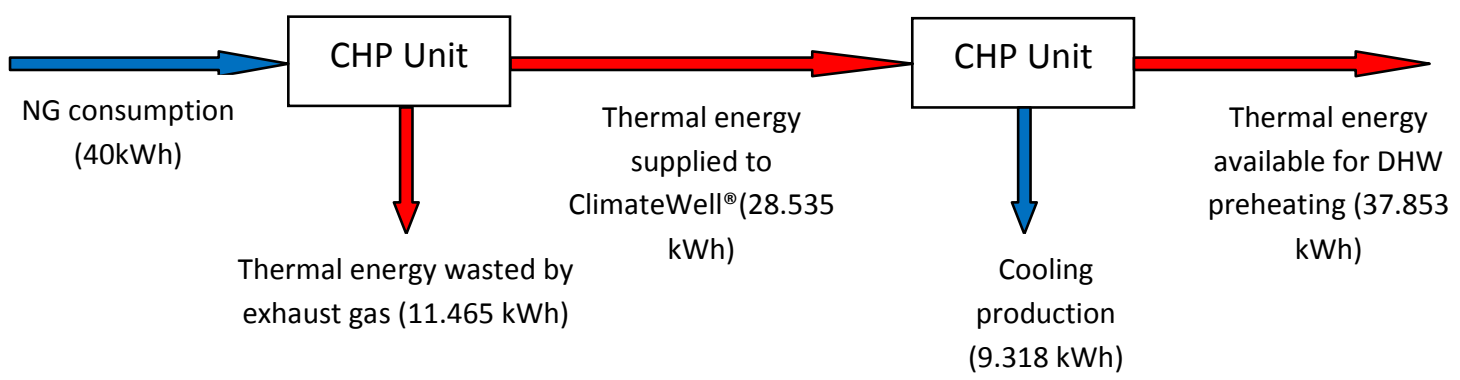

Figure 5.15 Energy flow diagram of the tri-generation system for each barrel of ClimateWell ${ }^{\circledR}$ chiller 


\section{Summary}

The residential tri-generation system as discussed in this chapter is an efficient way of utilizing the waste heat from the CHP unit. As the ClimateWell ${ }^{\circledR}$ chiller has the unique capability to store thermal energy, this can be advantageous in charging the chiller during the night time when the cooling demand is low, and then discharging it for cooling during the daytime. The combination of three DHW tanks helps to recover the waste heat which reduces the energy waste of the system. As the experiments were carried out during the start of the winter season, a lot of cooling testing was not possible under real world summer conditions. Also it was not possible to test the performance of the outdoor fan coil due to the lower ambient temperature. Data collected during the first phase of the project has been discussed in detail in this chapter. In the second phase of this project, researchers will dig more into the cost analysis of this residential tri-generation system to make it commercially viable. The combination of data collected from the first and the second phase of this project will help to optimise the tri-generation system in terms of operating cost and energy efficiency. This will also help to determine the sizing of a suitable CHP unit or other heat source that will be economically viable for this residential tri-generation system. 


\section{Chapter-6}

\section{TRNSYS Simulations}

This chapter describes briefly the TRNSYS model of the residential tri-generation system that has been used in this project. This model can be used to predict the performance of the overall system for different input conditions.

TRNSYS is a complete and extensible simulation environment for the transient simulation of systems including multi-zone buildings (Solar Energy Laboratory of University of Wisconsin, 2005). TRNSYS is used by engineers and researchers all over the world to validate new energy concepts, design and simulations of buildings and HVAC systems, alternative energy systems and thermal comfort. TRNSYS applications include solar systems, low energy building, HVAC, renewable energy, fuel cells etc. The source code of the kernel as well as the component models of TRNSYS are open to end users. This allows modifying the existing models to make them fit the user's specific needs. The DLL based architecture allows the users to easily add custom component models by using common programming languages (FORTRAN, C, C++, PASCAL etc.). Moreover, TRNSYS can be easily connected to many other applications (Microsoft Excel, Matlab, COMIS etc.) for pre or post-processing.

A TRNSYS project is usually setup by connecting components graphically in the simulation studio. Each type of component is described by a mathematical model in the simulation engine and has a set of matching proformas in the simulation studio. Proformas have a black-box description of a component: inputs, outputs, parameters etc.

\subsection{ClimateWell ${ }^{\circledR}$ chiller Model}

The ClimateWell ${ }^{\circledR}$ chiller model was supplied by the manufacturer. A Detailed code of the model was not provided as they possess a registered patent on it. The ClimateWell ${ }^{\circledR}$ chiller model comprises two different component's models, one for the TCA unit/barrel itself (TYPE215) and one for the switching \& controller unit (TYPE-216) (Klein et al., 2004). A more detailed description of the model was given by Norlander and Bales (2007). Figure 6.1 shows the simulation model for the complete ClimateWell ${ }^{\circledR}$ chiller. Figure 6.1 (a) shows the main masses, temperature and mass flow for a single TCA unit/barrel. There are four single node thermal 
masses: one each for the reactor and condenser/evaporator and one each for the water and solution storage vessel. The masses for the reactor and the condenser/evaporator are kept constant while the one for the storage vessel may vary depending on the state of charge of the machine due to the vapour transport between the parts (Bales, 2000). These masses are the effective masses as they include the thermal mass of the material of the vessel.

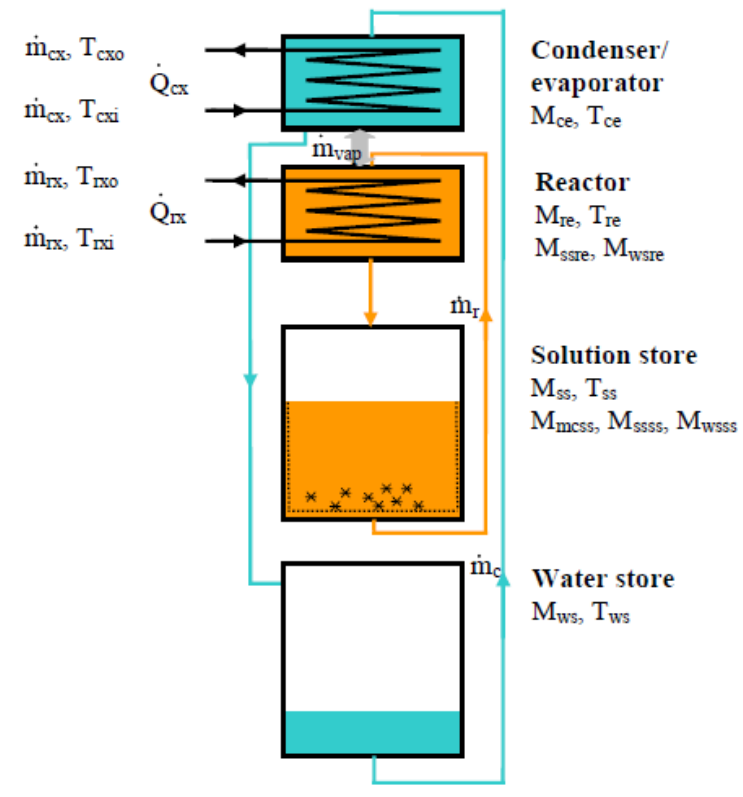

(a)

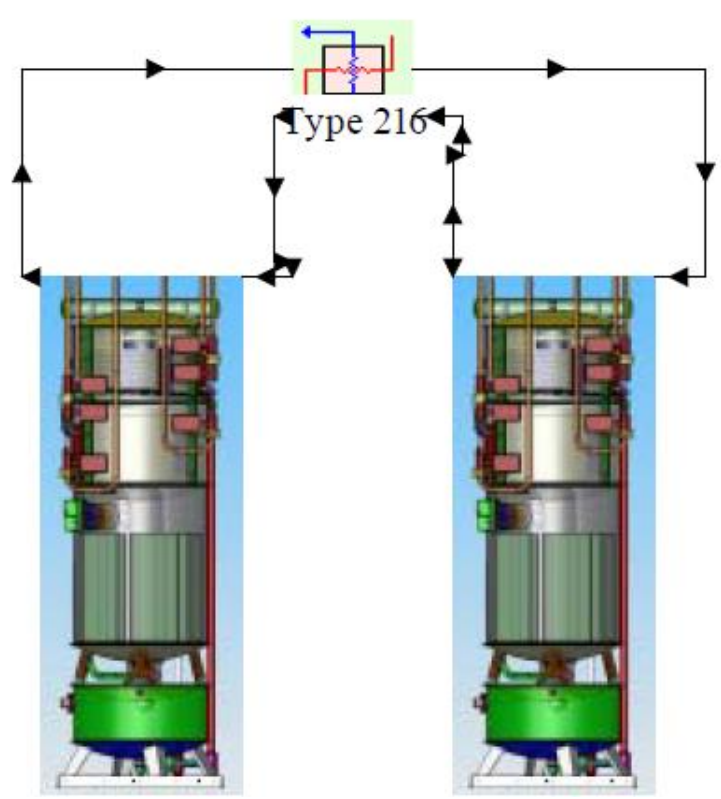

(b)

Figure 6.1 (a) Schematic of TYPE-215 single TCA unit/barrel (b) Complete ClimateWell ${ }^{\circledR}$ chiller comprising two barrels (TYPE-215) and a controller unit (TYPE-216) (Bales, 2000)

There is a mixing flow in between the storage vessels and the reactor and condenser/evaporator. The concentration of the solution at any state is calculated for the two solution parts: the reactor and the storage vessel. The temperature difference between the inlet fluid to the reactor and that to the condenser is dependent on the theoretical properties of the working pair using equations published by Conde (2004). This model also considers the heat of dilution during absorption of the water, enthalpy of crystallization and heat of vaporization for absorption and desorption as well as the sensible energy of the materials themselves. The model can calculate the required vapour flow, heating or cooling rates to maintain a user defined supply temperature during the discharge process. 
The model for the Switching \& Controller unit determines the state of charge (SOC) of a barrel. The algorithm used for this uses the same principle as that used in commercial machines. There are two modes to determine when a swap between the charge and the discharge needs to be performed. In mode-1, a swap is performed when a barrel is fully charged or the other barrel has finished discharging. In mode-2, a swap is performed when both barrels have finished charging and discharging.

\subsubsection{Parameter Identification}

The main parameters concerning the masses and properties of $\mathrm{LiCl}$ were fixed. The parameters for heat loss coefficients to the ambient were derived using the energy balance for a single unit for one complete cycle. Using the simulation model of the whole machine with the same boundary conditions as the tests, the internal heat loss coefficient was identified so that the COP of the simulated machine was the same as the measured value. Therefore automatic parameter identification was performed using the tools DF (Spirkel, 1998) and Fittrn (Huber, 1998) together with the model of the unit. Measured flows and temperatures were used as inputs to the models. Table 6.1 shows the main parameters identification of the model.

Table 6.1 Main parameters values for the ClimateWell ${ }^{\circledR}$ chiller (Bales, 2000)

\begin{tabular}{|c|c|c|}
\hline Parameter & Value & Identification \\
\hline $\mathrm{UA}_{\mathrm{re}}-$ heat loss coefficient for reactor & $8.6[\mathrm{~W} / \mathrm{K}]$ & From energy balance \\
\hline $\mathrm{UA}_{\mathrm{ce}}-$ heat loss coefficient for condenser & $8.6[\mathrm{~W} / \mathrm{K}]$ & From energy balance \\
\hline $\mathrm{UA}_{\mathrm{ss}}-$ heat loss coefficient for solution store & $9.2[\mathrm{~W} / \mathrm{K}]$ & From energy balance \\
\hline $\mathrm{UA}_{\mathrm{ws}}-$ heat loss coefficient for water store & $9.2[\mathrm{~W} / \mathrm{K}]$ & From energy balance \\
\hline $\mathrm{UA}_{\mathrm{int}}-$ heat transfer coefficient between reactor & $16.7[\mathrm{~W} / \mathrm{K}]$ & From COP test \\
and condenser during charge & & \\
\hline $\mathrm{UA}_{\mathrm{ch}}-$ heat transfer coefficient for charging & $9992[\mathrm{~W} / \mathrm{K}]$ & TRNSYS + DF \\
\hline $\mathrm{UA}_{\mathrm{di}}-$ heat transfer coefficient for discharging & $4231[\mathrm{~W} / \mathrm{K}]$ & TRNSYS + DF \\
\hline
\end{tabular}




\begin{tabular}{|c|c|c|}
\hline Parameter & Value & Identification \\
\hline $\mathrm{f}_{\mathrm{dp}}-$ pressure drop factor for vapour flow & $9.62[-]$ & TRNSYS + DF \\
\hline $\mathrm{m}_{\mathrm{r}}-$ internal circulation flow of solution & $0.278[\mathrm{~kg} / \mathrm{s}]$ & TRNSYS + DF \\
\hline $\mathrm{m}_{\mathrm{c}}-$ internal circulation flow of water & $0.225[\mathrm{~kg} / \mathrm{s}]$ & TRNSYS + DF \\
\hline
\end{tabular}

\subsubsection{Model Verification}

The model developed by the manufacturer is used as the standard model for the ClimateWell ${ }^{\circledR}$ chiller. This model was validated by the manufacturer to make sure that it predicts accurately the behaviour of the machine. Figure 6.2 shows the measured and simulated value of the heat transfer rate for the reactor and the condenser of a single barrel over two full cycles (Bales, 2000). The agreement between the experimental and simulated data is in general good except at the start of the cycle. According to the experimental data, during the initial phase of the charging cycle, there is only sensible heat transfer and the desorption process starts only when the temperature reaches a higher value. In the model, the desorption starts a little bit earlier than observed. This is due to the varying concentration of the salt and the resulting vapour pressure above the salt.

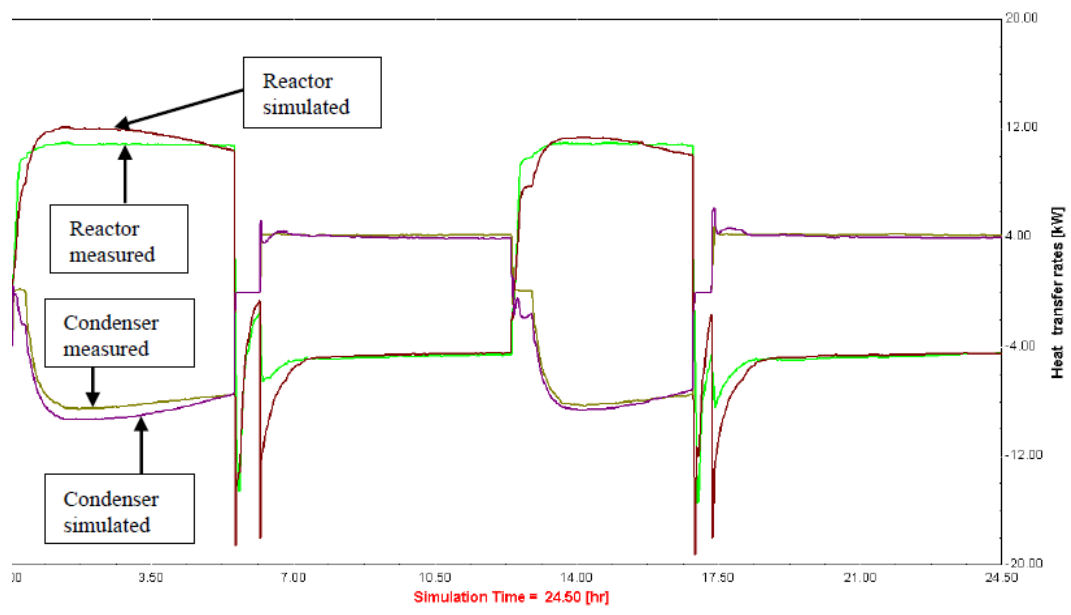

Figure 6.2 Measured and simulated heat transfer rates for reactor and condenser for two full cycles of a single barrel (Bales, 2000) 
Figure 6.3 shows the comparison of the heat rejection temperature between the experimental data and the simulation result during the charging cycle of Barrel-A. The charging experiment of Barrel-A was conducted on November 12 $2^{\text {th }}, 2012$ and it started at 12:48 PM. In Figure 6.3, T34 represents the heat rejection temperature from the ClimateWell ${ }^{\circledR}$ chiller to the heat sink. It is observed that the simulation results show the ideal case with slight variance. On the other hand, the experimental data shows fluctuations throughout the charging cycle. This is because during the experiment, thermal energy supplied from the CHP unit was fluctuating due to the frequent on and off cycle of the CHP unit. It is observed that there is good agreement between the simulation data and the experimental data as both of them followed the same trend. There is about $2-3{ }^{\circ} \mathrm{C}$ difference in temperature between the experimental data and the simulation results.

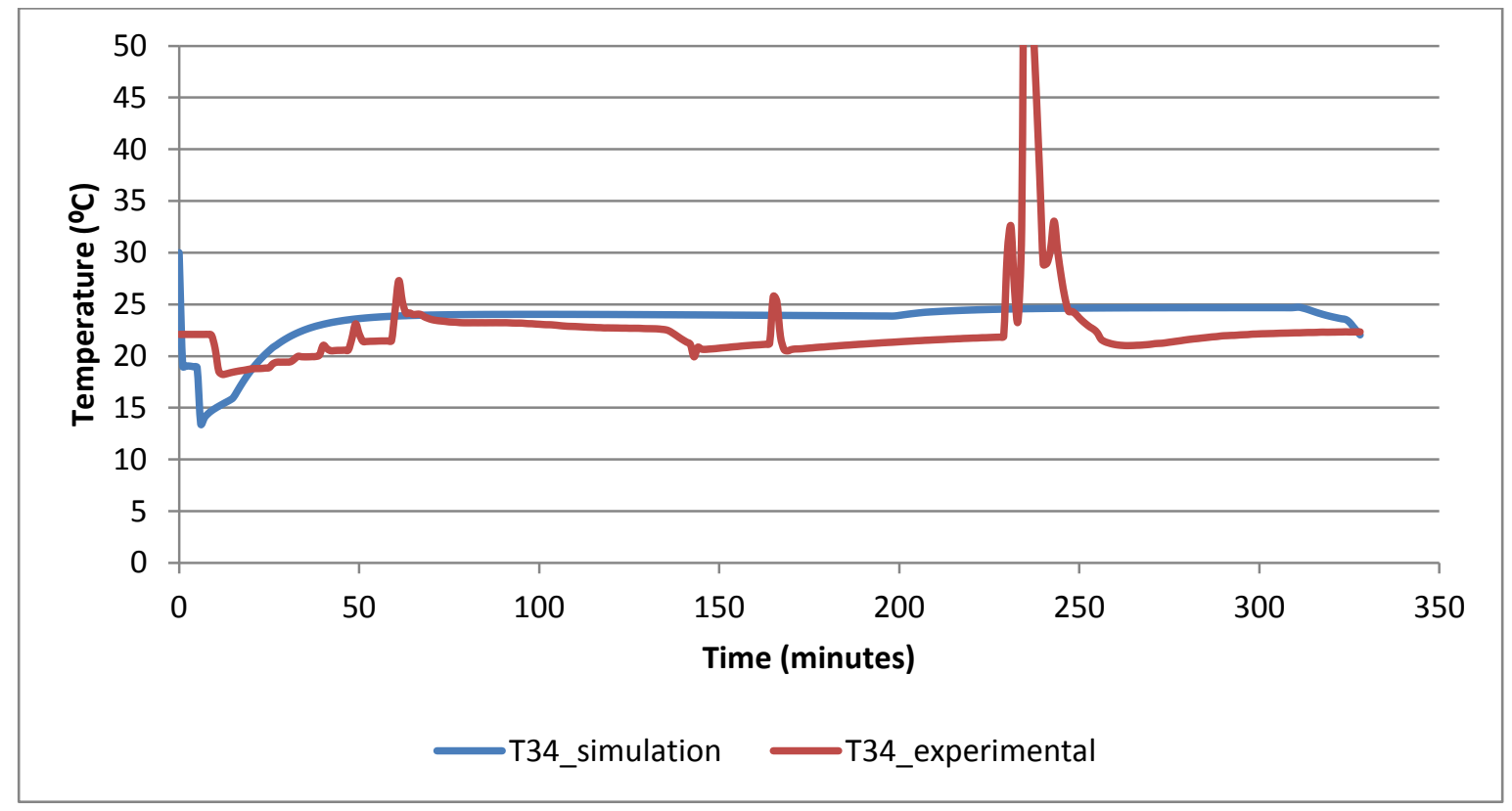

Figure 6.3 Comparison of experimental and simulation result for heat rejection temperature

\subsection{DHW Tank Model}

In TRNSYS 17, there are 5 pre-existing thermal storage component models. Among the existing 5 thermal storage models, Types 4, 38 and 60 model the behaviour of fixed volume stratified storage tanks. Type 4 is the simplest but it only subdivides the storage volume into 15 fully mixed layers. Previous work shows that it is difficult to accurately predict the temperature of 
water inside the tank if the number of layers is low (Newton, 1995 and Cruickshank \& Harrison, 2006) the TYPE 38 routine is based on a "plug flow" model. It adjusts the number of layers to accommodate the flow in and out of the storage tank. But, the tank temperature profiles are not available, so this model was not used in this work.

The TYPE 60 routine is based on the work of Newton (1995) and was used in this residential trigeneration project. TYPE 60 models the storage tank considering $\mathrm{N}$ fully mixed layers of equal volume. In addition, TYPE 60 has its own internal time steps to minimize the errors. TYPE 60 allows $\mathrm{N}$ to take values up to 100 and a large number of nodes allows the prediction closer to the ideal situation (Cruickshank \& Harrison, 2006).

Figure 6.4 shows the comparison between the experimental data and simulation results for the DHW tank (TB-3) temperature during part of a charging cycle of Barrel-A. In Figure 6.4, T23 represents the temperature of the water at the outlet of the first tank (TB-3). From Figure 6.4, it is observed that the simulation result shows almost constant temperature with only slight variance. On the other hand, experimental data shows fluctuations due to the frequent on and off cycles of the CHP unit. There is a slight disagreement of about $1-2^{\circ} \mathrm{C}$ between the experimental data and the simulation results.

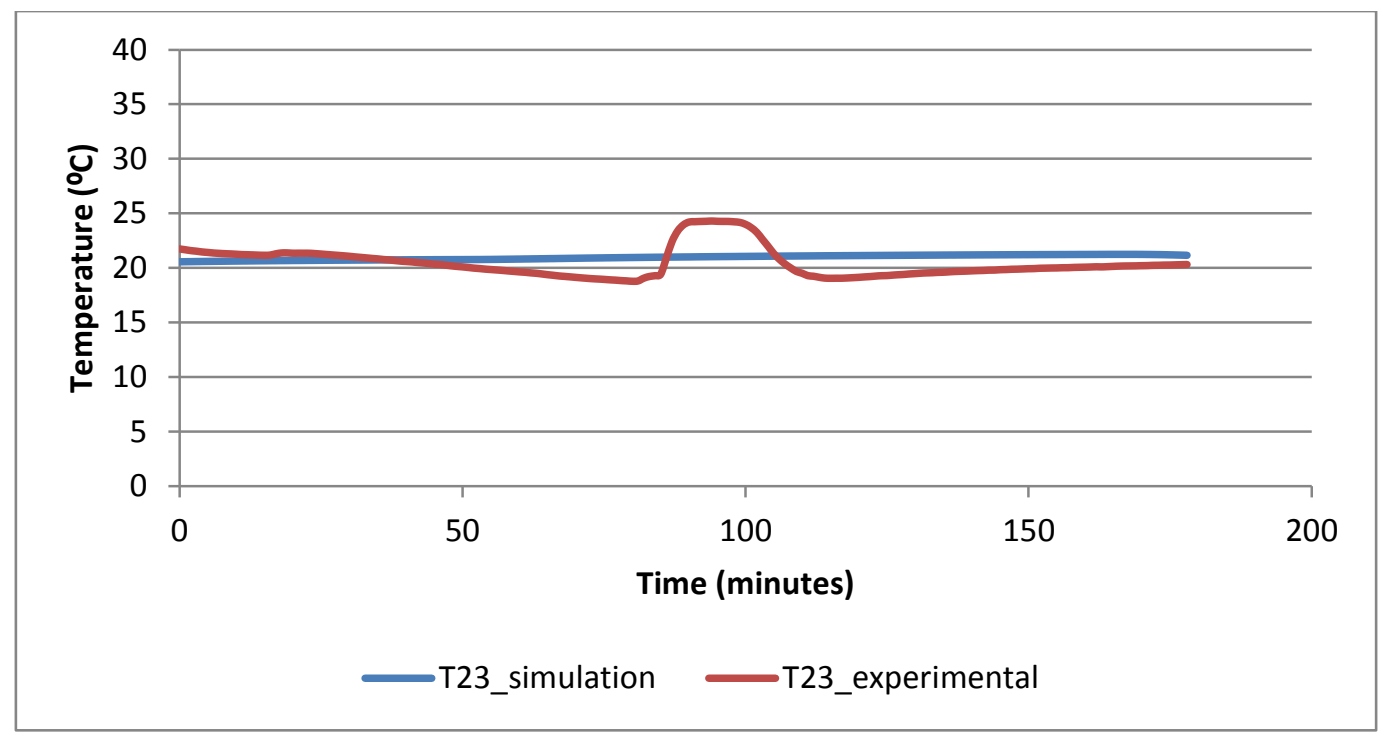

Figure 6.4 Comparison of experimental data and simulation results for water temperature in the DHW tank (TB-3) 


\subsection{Tri-generation Model}

The TRNSYS model of the ClimateWell ${ }^{\circledR}$ chiller supplied by the manufacturer was created in version 17 of the software. So, the model of the tri-generation system was also created in the same version of the software. Figure 6.5 shows the TRNSYS model of the tri-generation system with the three DHW tanks for heat recovery. Standard components from the TRNSYS library were used except the macro V-93, which represents the ClimateWell ${ }^{\circledR}$ chiller. The macro V-93 contains both the barrels and the controller unit. This macro was supplied by the manufacturer and was locked by them. The users privy to the algorithm of this macro. In the model, heat losses from the pipes were not considered. Also it was not possible to accurately model the cyclic behaviour of the CHP unit. This model can be used to predict the behaviour of the tri-generation system for different input conditions.

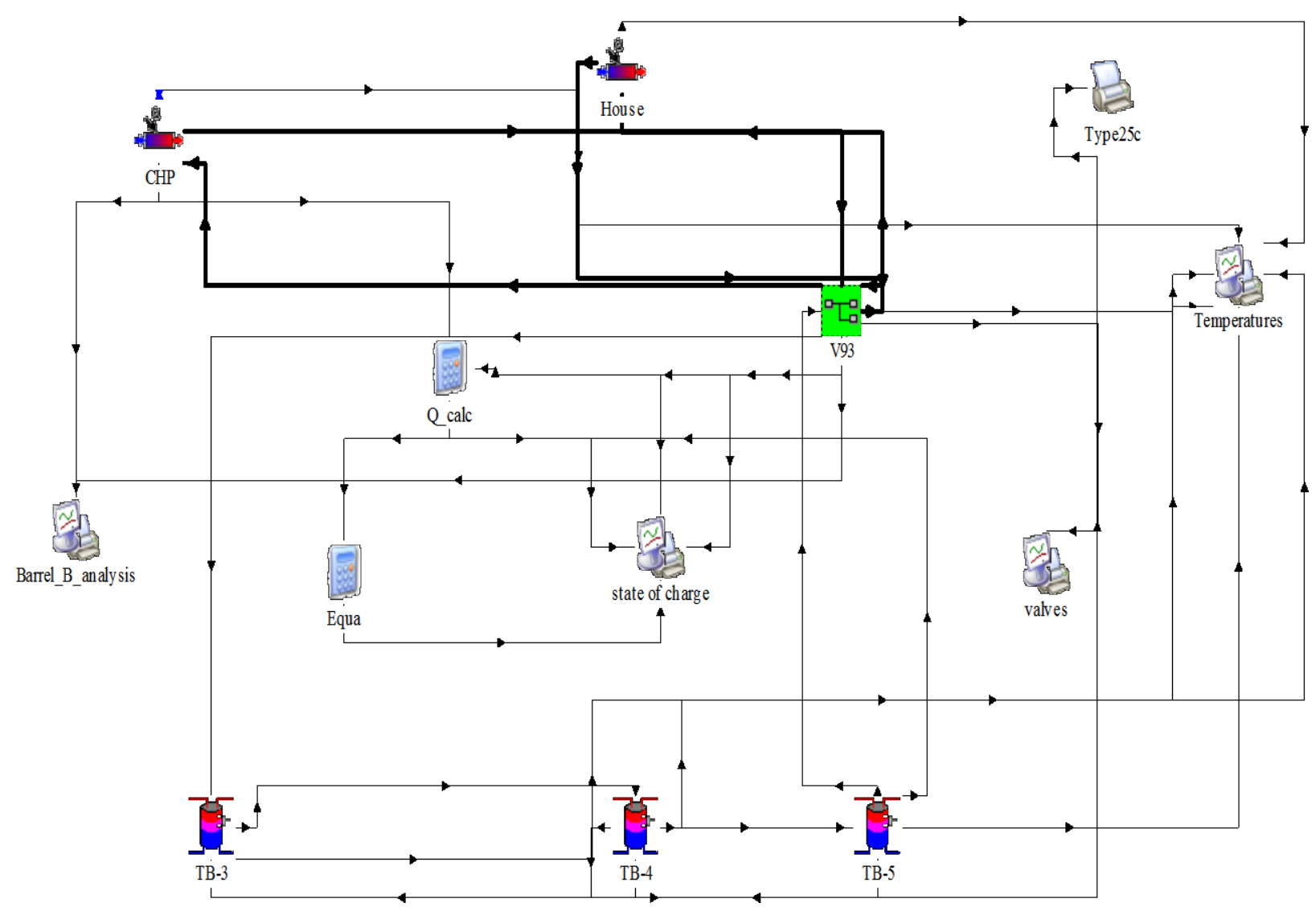

Figure 6.5 TRNSYS model overview of the residential tri-generation system 


\subsection{Simulation Results}

The developed tri-generation model can be used to investigate the charging and discharge behaviour of the ClimateWell ${ }^{\circledR}$ chiller under different conditions. Figure 6.6 shows the simulation data for 40 hours showing the state of charge (SOC). The simulation was performed in normal mode which allows one barrel to discharge while the other one is charging. From this figure it is observed that with the existing CHP it takes almost 5 hours to charge each barrel. Also it is noticed from Figure 6.6 that with the existing CHP, it is possible to charge nearly $80 \%$ of each barrel. The experimental results show that it was possible to charge $65 \%$ of each barrel. Also the experimental COP was 0.365 which is much lower than the rated value. The discrepancies may be attribute to the vacuum seal quality in the barrels.

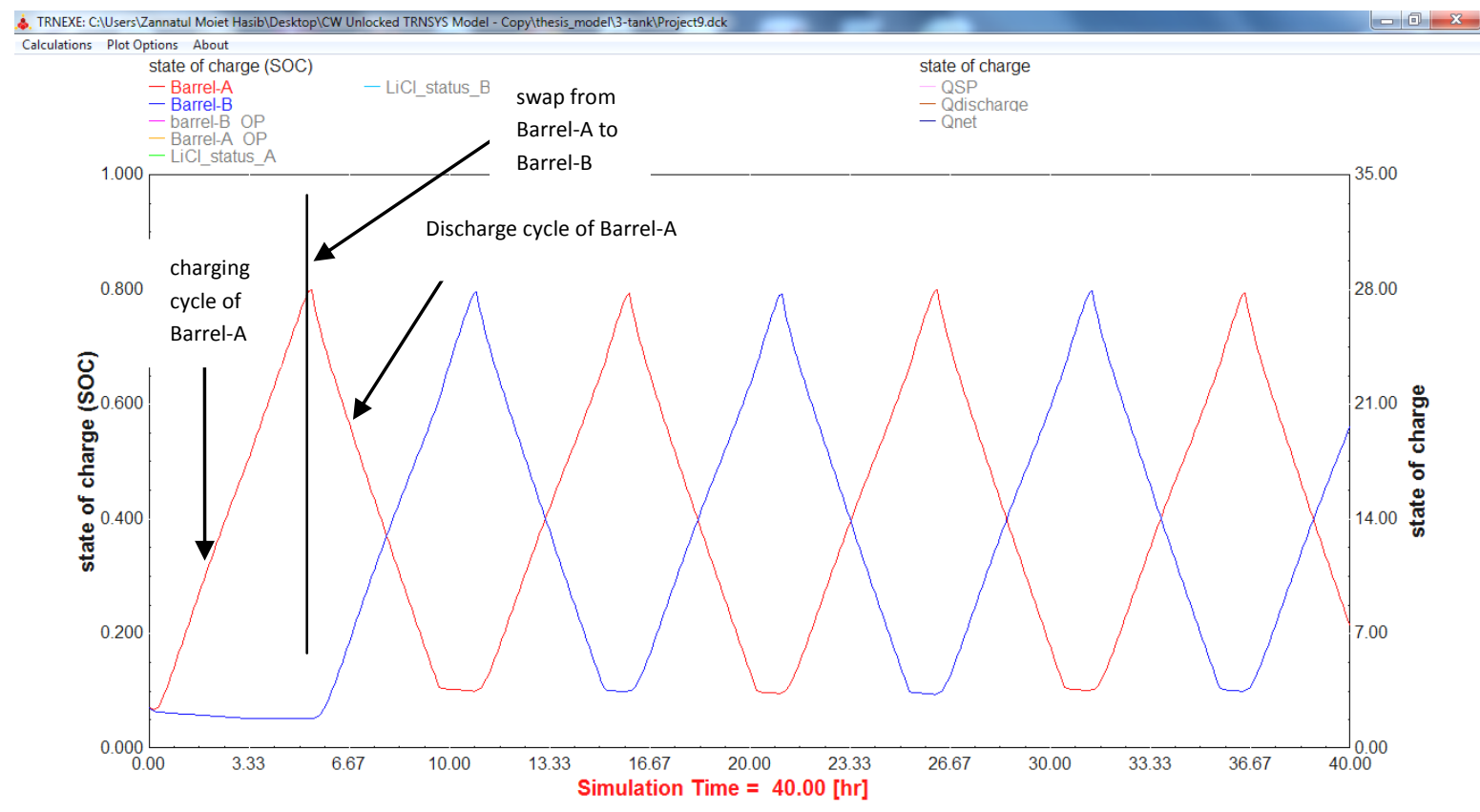

Figure 6.6 Simulation result for SOC vs. time

Figure 6.7 shows the simulation data for 40 hours showing the temperature profile for the charging circuit and the heat rejection circuit. In Figure 6.7, T32 represents the temperature of the working fluid from the CHP entering the ClimateWell ${ }^{\circledR}$ chiller and T31 represents the temperature of the working fluid from the ClimateWell ${ }^{\circledR}$ chiller back to the CHP. T34 represents temperature of the heat rejection from the ClimateWell ${ }^{\circledR}$ chiller. From Figure 6.7, it is noticed that the heat rejection temperature is about $65^{\circ} \mathrm{C}$ lower than the charging temperature. The heat 
rejection temperature is within the range of $30-32^{\circ} \mathrm{C}$ and it remains steady throughout the charging cycle and drops towards the end of the cycle. It is also noticed from Figure 6.7 that the supply temperature (T32), from the CHP increases with time and the temperature reaches to a higher value towards the end of the charging cycle. Both the supply temperature and the heat rejection temperature follow a similar trend.

Figure 6.8 shows the simulation data for the heat transfer rate with time for the charging and the heat rejection circuit. In this figure, $\dot{Q}_{\text {Thermal }}$ represents the heat supply rate from the CHP and $\mathrm{Q}_{\text {Rejection }}$ represents the heat rejection rate from the ClimateWell ${ }^{\circledR}$ chiller. From Figure 6.8, it is observed that the heat rejection rate is about $6 \mathrm{~kW}$ in the first charging cycle and from the second cycle, the heat rejection rate is about $13 \mathrm{~kW}$. This is because in the first cycle, only Barrel-A was charging and from the second cycle onward, one barrel discharges while the other one is charging. It is also observed from this figure that the heat rejection rate drops towards the end of the cycle which indicates that the chiller absorbs a substantial amount of thermal energy towards the end of the charging cycle.

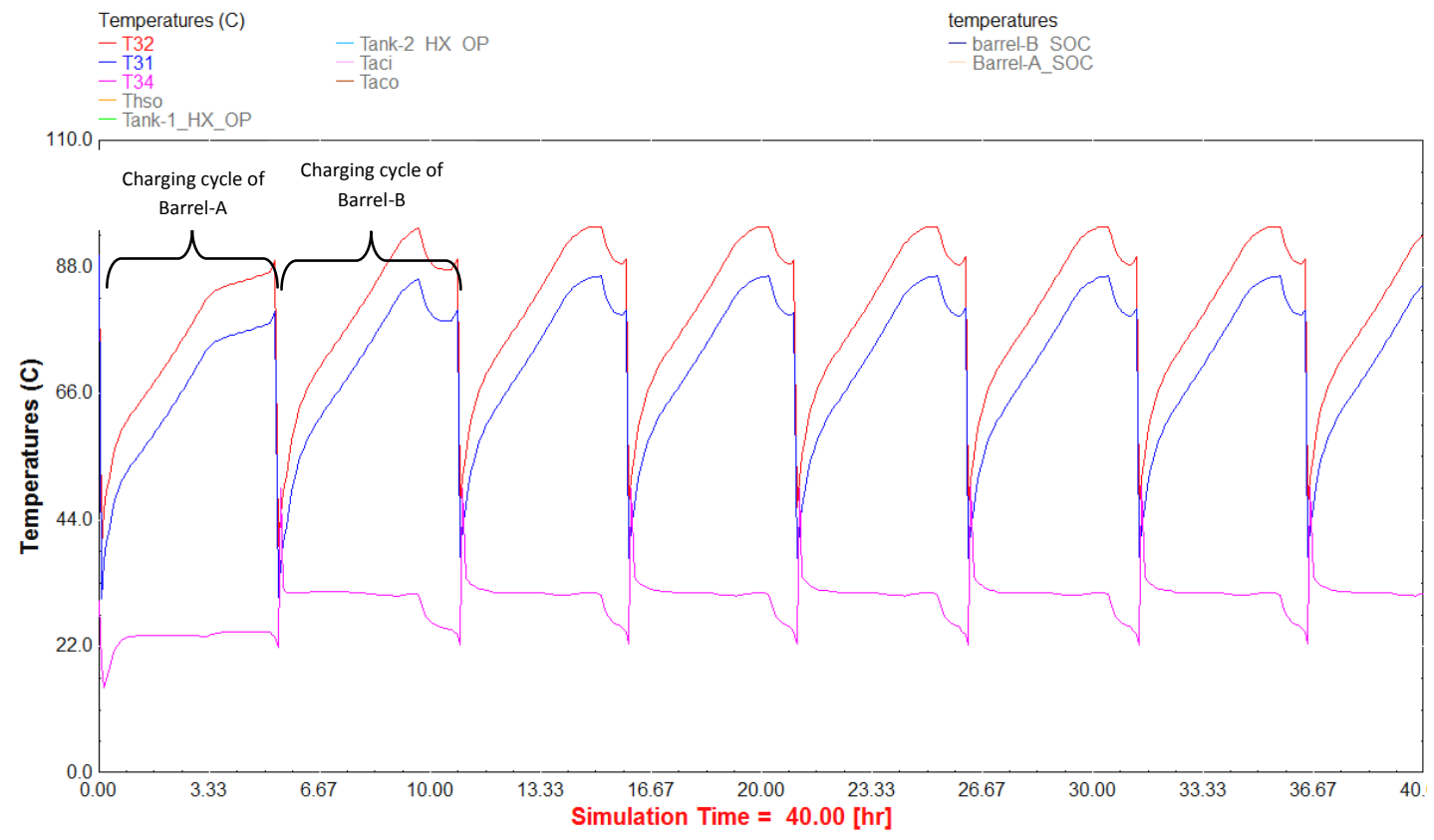

Figure 6.7 Simulation results for temperature vs. time for charging the ClimateWell chiller 


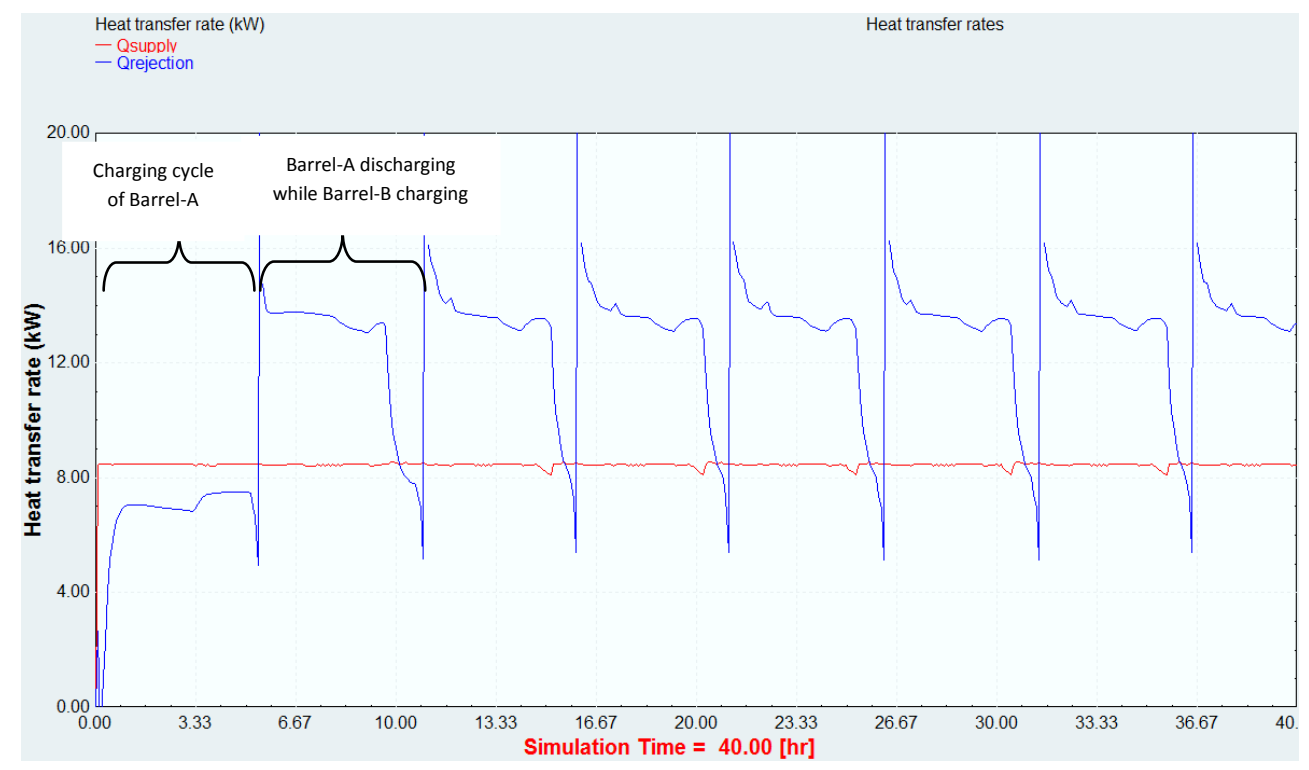

Figure 6.8 Simulation result for heat rate vs. time

Figure 6.9 shows the simulation result of temperature at different points of the tri-generation system. In the simulation, it was considered that the chiller is operated in normal mode which allows the barrels to swap alternately as one barrel discharges while the other one is charging. In Figure 6.8, T23, T39 and T40 represent the temperature of the water in the DHW tanks TB-3, TB-4, and TB-5, respectively. T34 represents the heat rejection temperature from the ClimateWell $^{\circledR}$ chiller. From Figure 6.9, it is observed that the heat rejection temperature is about $31-32^{\circ} \mathrm{C}$. This rejected energy is utilized to preheat the DHW. From Figure 6.9, it is also observed that tank TB-3 contains the highest temperature water (T23) and tank TB-4 contains mid temperature water (T39). As shown in Figure 5.7 of Chapter-5, the temperature of the main's cold water during the experiment was $16{ }^{\circ} \mathrm{C}$ with slight variation. So, in the simulation, the main's cold water temperature was considered to be $16^{\circ} \mathrm{C}$ with a flow rate of $61 / \mathrm{min}$. The temperature of the water in tank TB-5 (T40) is only about $1-2^{\circ} \mathrm{C}$ higher than the main's cold water. This is because tank TB-3 and tank TB-4 recover the majority of the rejected energy from the chiller and after that only a small portion is left over to reject in the last tank (TB-5). 


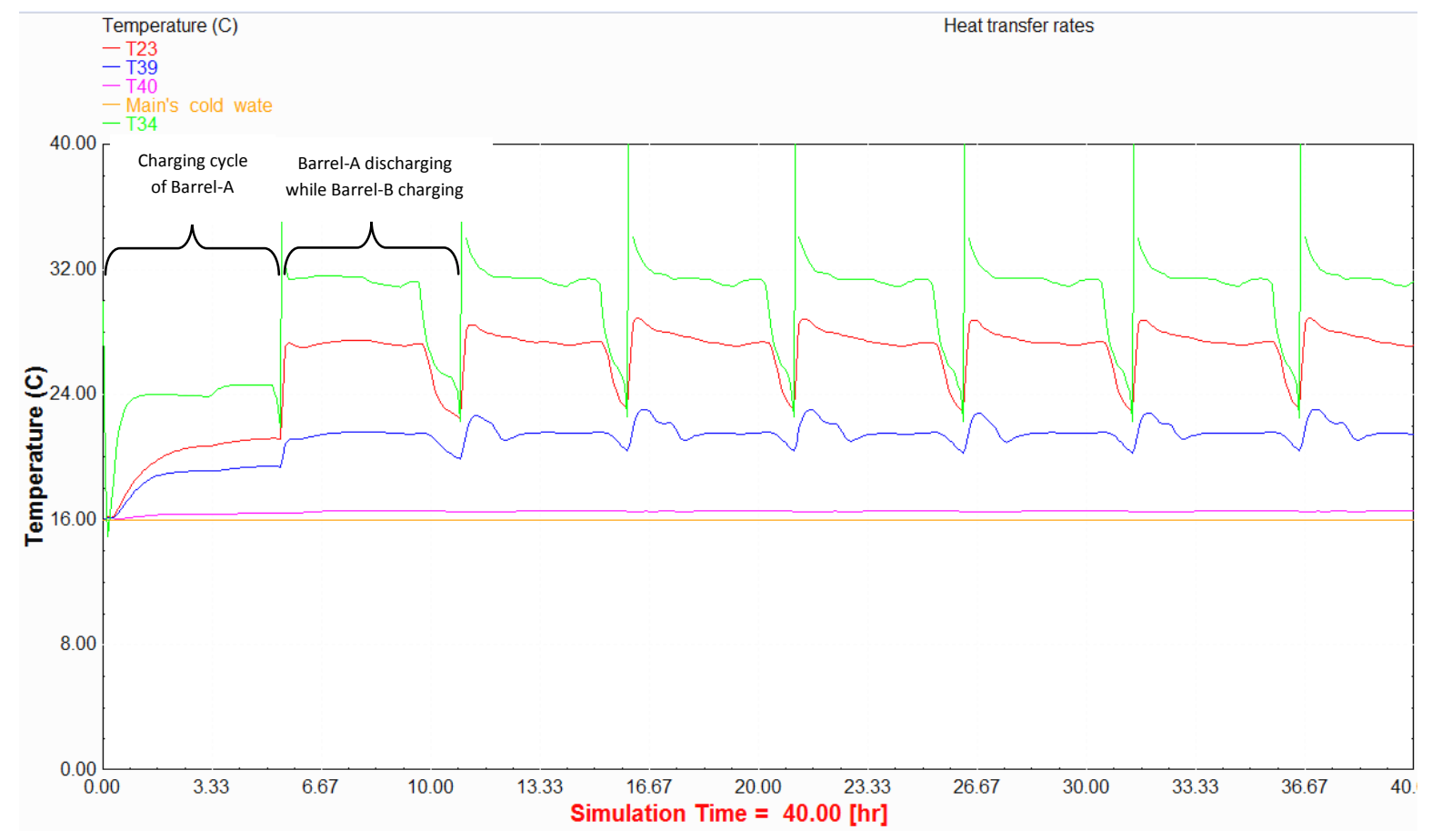

Figure 6.9 Simulation result for temperature vs. time at different points of the trigeneration system

Figure 6.10 shows the temperature of the chilled water in the discharge circuit. In Figure 6.10, T14 represents the temperature of the chilled water supplied from the ClimateWell ${ }^{\circledR}$ chiller and T13 represents the temperature of the water returning back to the chiller after it had passed through the AHU. It is observed that the simulation result shows that the chiller can supply water at a temperature as low as $5^{\circ} \mathrm{C}$. Also it is noted that the temperature of the chilled water starts to increase towards the end of the discharge cycle. In reality, the lowest observed chilled water temperature supplied by the chiller was $11^{\circ} \mathrm{C}$. This is because, in the simulation it considers the ideal case with both the barrels properly vacuumed and it does not take into account the losses in pipes, heat exchangers and in the pumps. It is also noticed from Figure 6.9 that at the end of each discharge cycle, the temperature of the chilled water starts to rise sharply. 


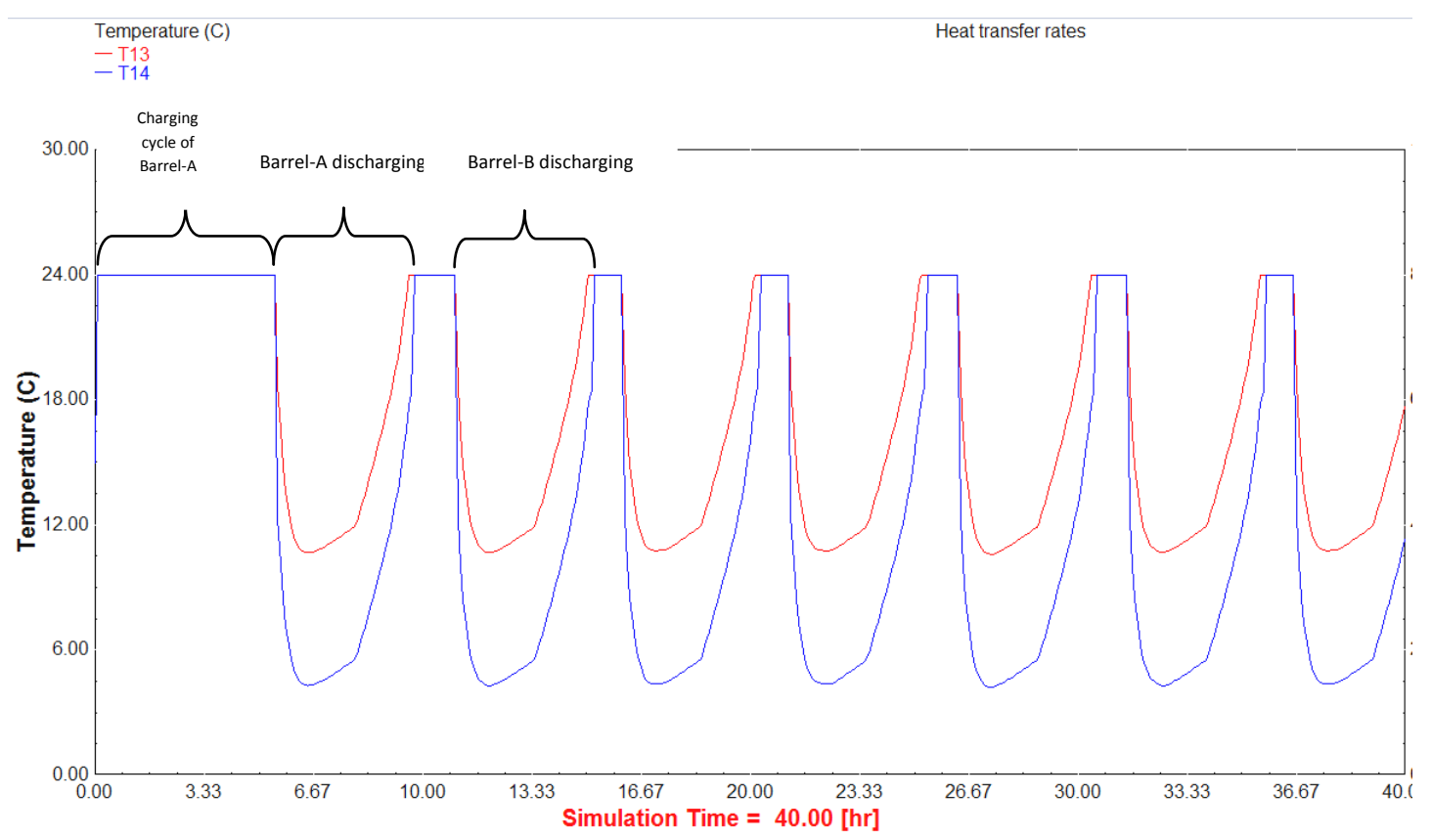

Figure 6.10 Simulation result for temperature vs. time in discharge circuit

From Figure 6.11, it is observed that the charging cycle is longer than the discharge cycle for a discharge rate of $5 \mathrm{~kW}$. That is why, at the end of each cycle, there is a time period of about 45 minutes when the chiller is not able to provide cooling. This is due to the lower heat transfer capacity of the CHP. By increasing the heat transfer capacity of the CHP, it is possible to shorten the charging cycle, which can result in uninterrupted cooling supply. 


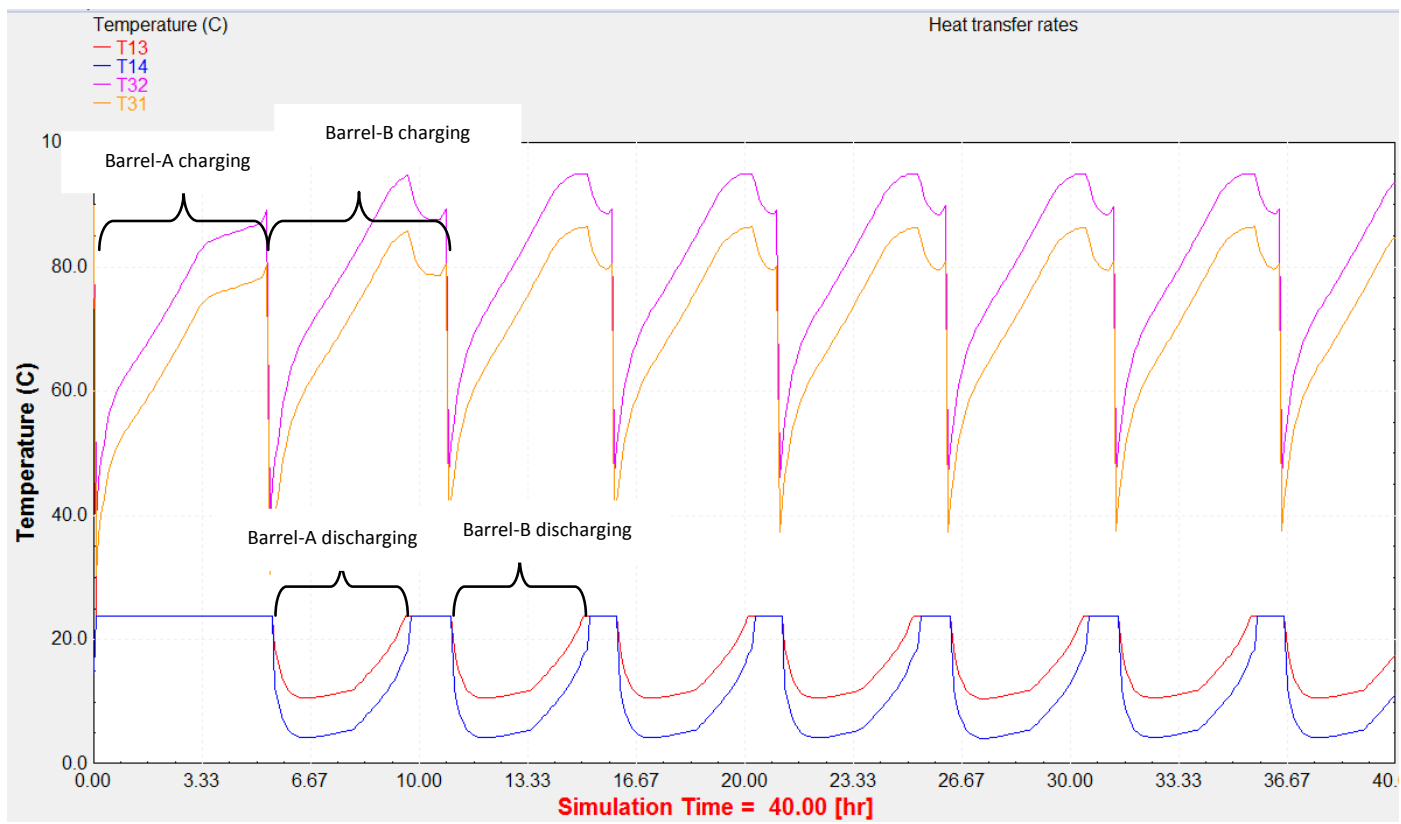

Figure 6.11 Charging and discharge cycle of the ClimateWell ${ }^{\circledR}$ chiller

\section{Summary:}

The TRNSYS model of the residential tri-generation system as discussed in this chapter can be used as an engineering tool to predict the behaviour of the system prior to installation. This model is also useful to determine the temperature of the water in the DHW tanks and also the heat recovery by the three DHW tanks. This model can also help to find a suitable and alternative heat source for the residential tri-generation system. This model can also help to find other ways of utilizing the waste heat from the tri-generation system. This is a preliminary model for the residential tri-generation system based on the ClimateWell ${ }^{\circledR}$ chiller and the gas fired Stirling CHP. Researchers, who will be working on the second phase of this project will use this model to optimize the residential tri-generation system from the prospective of cost, GHG emission, efficiency and others. 


\section{Chapter-7}

\section{Author's Contribution and Conclusion}

This thesis is related to the residential tri-generation system based on a gas fired Stirling engine CHP and ClimateWell ${ }^{\circledR}$ technology. This thesis discusses details about a prefeasibility study, installation and commissioning work, experimental data analysis and simulation results of the integrated system. In this regard, the author has finished the following activities:

- Studied and explained in detail absorption, adsorption and the ClimateWell ${ }^{\circledR}$ technology.

- Developed a detailed design of a residential tri-generation system and a multi-tank cascade storage system to produce DHW by utilizing the rejected energy from the trigeneration system.

- Assisted with the installed and commissioning of the tri-generation system in the basement of House-B of the TRCA, located in Vaughan, Ontario.

- Analyzed the experimental data collected from all the sensors to evaluate the performance of the system and its components.

- Developed a TRNSYS model of the tri-generation system and the multi-tank cascade storage system.

- Verified the simulation results with the experimental data and have simulated the trigeneration system for different input conditions.

\subsection{Conclusions}

Combined heating, cooling and power (CHCP) technologies already exist, mainly in large scale applications and some district heating. The goal of this work was to scale down the CHCP technology for residential purposes. In most of the previous works, thermally driven chillers for residential application were operated by a solar collector or gas fired boiler. In this work, the thermally driven chiller was operated by the waste heat from a CHP system. Moreover, this was the first time that the ClimateWell ${ }^{\circledR}$ chiller was tested for the Archetype Sustainable House (ASH) in North American climates. This project also included development of a transient model for the integrated system which has not been carried out in previous research. In all of the 
previous projects where ClimateWell ${ }^{\circledR}$ participated, wet cooling towers and/or a swimming pool was used for heat rejection. In this work, a multi-tank cascade heat storage system was used to recover the waste heat from the tri-generation system to utilize it in preheating DHW.

The three DHW tanks were plumbed in series and the water main's cold water was supplied in a counter flow manner so that thermal diode effect can be achieved, wherein each heat-exchanger would supply heat energy to the tanks and would not transfer energy from a hot tank to a cold one. As a result a cascade storage system was formed. In the cascade storage system, the first tank contained the highest temperature water, the second tank contained mid temperature water and the third tank contained the lowest temperature water. Experimental data shows that first DHW tank utilizes about $42 \%$ of the total rejected energy from the chiller. The second and third DHW tanks utilize $31 \%$ and $26 \%$ of the rejected energy, respectively. Utilizing the rejected energy from the chiller, it was possible to preheat the main's cold water to raise its temperature from $16^{\circ} \mathrm{C}$ to $22^{\circ} \mathrm{C}$ during the experiment. Preheating the water reduces the electricity or natural gas consumption of the house associated with DHW production and also increases the overall efficiency of the tri-generation system.

It was also observed from the experimental data that the heat transfer rate from the immersed heat exchanger of each tank was about $1.38 \%$ lower than the rated value at a given temperature. This is because, the three DHW tanks that were used in this project were new and it was the first time that those tanks were used for the experiment. So, there was no scale formation on the outer or inner surface of the heat exchangers which would otherwise degrade performance. After a few years of use, there might be scale formation on the outer and inner surface of the heat exchangers that may cause deterioration of its performance.

Simulation was also carried out for the parallel orientation of the three DHW tanks. For a parallel orientation, all the three tanks contain the same temperature water. The required flow rate of the cooling water for the parallel configuration is also higher than for the series configuration. For the parallel orientation of the three DHW tanks, the main's cold water should be equally divided to the three DHW tanks and also the heat rejection flow from the chiller should be equally segregated to supply the tanks. In reality, such a configuration it is difficult to maintain. 
Due to the frequent cyclic behaviour of the CHP, the overall performance of the tri-generation system was poor and also the charging time was much longer than predicted. Also due to the lower supply temperature by the CHP, it was not possible to fully (100\%) charge the barrels. The cyclic behaviour of the CHP also affects the COP of the chiller. So, it is highly recommended to search for a $\mathrm{CHP} /$ alternative heat source that can supply energy continuously during the charging cycle.

Due to global warming, cooling demand in residential buildings is increasing. Traditional airconditioning systems driven by electricity highly stress the grid during the summer time. The residential tri-generation system as discussed in this thesis can help to reduce the stress in the grid during the summer season. Moreover, as the tri-generation system does not use halocarbon refrigerants, it is environmentally friendly. Through a program of experimentation and design, this research provides a fundamental understanding about the residential tri-generation system. This research can also be used as a guide tool for the manufacturers' who want to promote gas fired residential tri-generation systems in North America.

\subsection{Recommendations and Future Works}

The author has made the following recommendations for future works about this project:

- Due to the frequent cyclic behaviour of the CHP, the performance of the overall system was not desirable. So, it is highly suggested to search for a CHP/alternative heat source that can supply thermal energy continuously during the charging cycle of the ClimateWell ${ }^{\circledR}$ chiller.

- Performance of the system can also be improved by adding a couple of electric heaters in series with the existing CHP so that the combination can supply thermal energy at a higher temperature of around $110-120^{\circ} \mathrm{C}$.

- As the experimental data shows a COP of 0.365 , which is much lower than the rated COP, it is strongly suggested to check the vacuum level of both the barrels before starting new experiments.

- Flow control valves that are used in this project, can be automated and an algorithm can be developed to operate those valves, which would be more convenient for residential applications. 
- Detailed analysis considering gas price, electricity price, cooling demand and other parameters should be carried out to develop a control strategy for the optimization of the tri-generation system.

\subsubsection{Performance Map of ClimateWell ${ }^{\circledR}$ chiller}

Several tests are required to carry out to map the performance of the ClimateWell ${ }^{\circledR}$ chiller which are explained below:

- The COP of the chiller largely depends on the charging rate supplied by the thermal source. Tests should be carried out at different charging rates in order to find the optimum COP based on charging rate.

- The COP of the chiller is also dependent to the re-cooling temperature of the heat rejection flow. Experiments should be carried out at different re-cooling temperatures to find the relationship in between the COP and the re-cooling temperature of the heat rejection flow.

- The heat rejection rate and temperature of the chiller depends on the charging temperature. To map the heat rejection behaviour of the chiller during the charging cycle, charging tests should be carried out at different temperatures to find the relationship in between the charging temperature and the heat rejection temperature/rate.

- The chilled water supply temperature by the chiller is dependent on the heat rejection rate and the re-cooling temperature of the heat rejection flow. Experiments should be carried out for different chilled water temperatures and the re-cooling temperature in order to find the relationship in between them.

- The manufacturer claims that the ClimateWell ${ }^{\circledR}$ chiller is capable of holding the stored energy for longer period without any losses. To verify this, the chiller should be charged fully and then the charge level should be measured at an interval of weeks/months. 


\section{Appendix-A}

\section{Previous Projects Related to ClimateWell ${ }^{\circledR}$}

In Europe, during 2006-2009, the ClimateWell ${ }^{\circledR}$ chiller was used in different projects on a test basis. Brief descriptions about some of those projects are listed below.

\section{Project-1:}

\begin{tabular}{|c|c|}
\hline Project leader & $\begin{array}{l}\text { Chris Bales } \\
\text { SERC } \\
\text { Forskargatan } 6 \\
\text { SE-78188 Borlänge } \\
\text { Sweden } \\
\text { Phone: +46-23 } 778707 \\
\quad \text { cba@du.se }\end{array}$ \\
\hline Other partners involved & $\begin{array}{l}\text { ClimateWell }^{\circledR} \\
\text { KTH } \\
\text { FSKAB }\end{array}$ \\
\hline Location & Borlänge, Sweden, 2000 \\
\hline
\end{tabular}

This project was carried out in 2006 in Borlänge, Sweden. It provided pre-cooling to a large compression chiller by supplying cold water at a temperature of $10-13^{\circ} \mathrm{C}$. Version 7 of the ClimateWell ${ }^{\circledR}$ unit, which is different from CW 10 was used in this project. Version 7 contained 4 circulation pumps with high electricity consumption. Noise by the pumps and leakages in pipelines were some of the problems associated with the previous version. A district heating network was used to charge the $\mathrm{CW}$ chiller. A functional block diagram of the project is given in Figure A.1 and Figure A.2 shows installation of the Climatewell ${ }^{\circledR}$ version 7.0 chillers in Project2. 


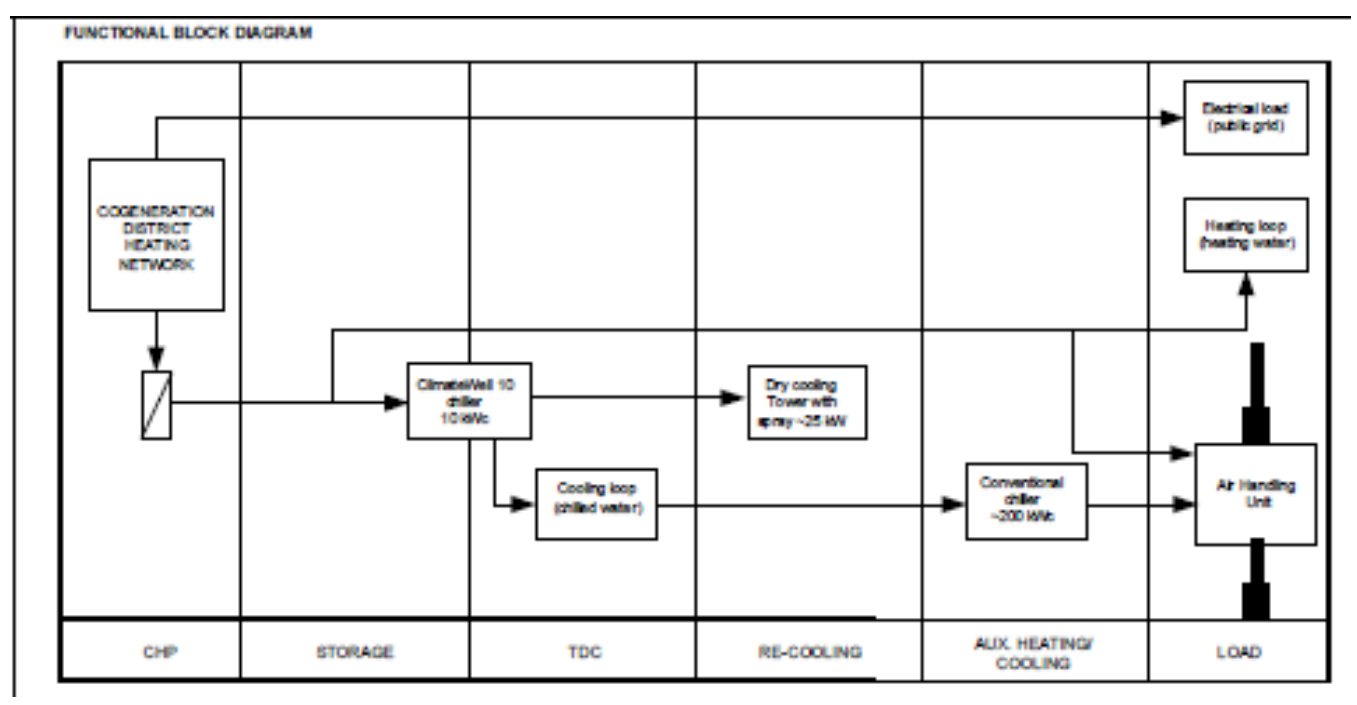

Figure A.1 Functional block diagram of Project-1 (Nurenz, 2010)
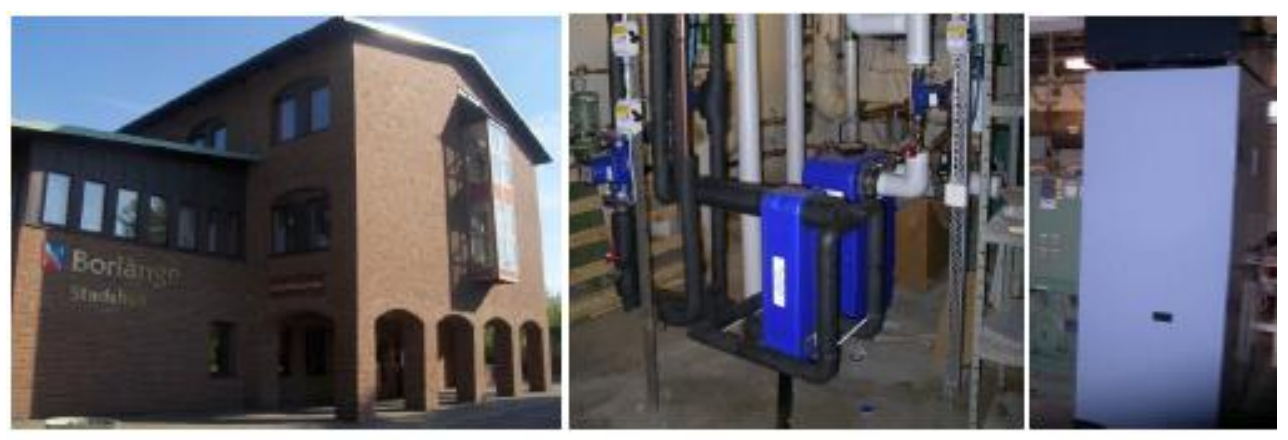

Figure A.2 Installation of Climatewell ${ }^{\circledR}$ version 7.0 chiller in Project-1 (Nurenz, 2010)

The monitoring period began on August $6^{\text {th }}, 2007$ and ended on September $28^{\text {th }}, 2008$ giving a total of 187 days of monitoring. The system ran only in the cooling season which is about 3-4 months per year. The first cooling season in 2007 was used to understand the control strategy of the system and the real testing period was in 2008. The energy balance of the integrated system during the summer is given in Figure A.3. A Detailed report on this project can be found at WwW.polysmart.org. 


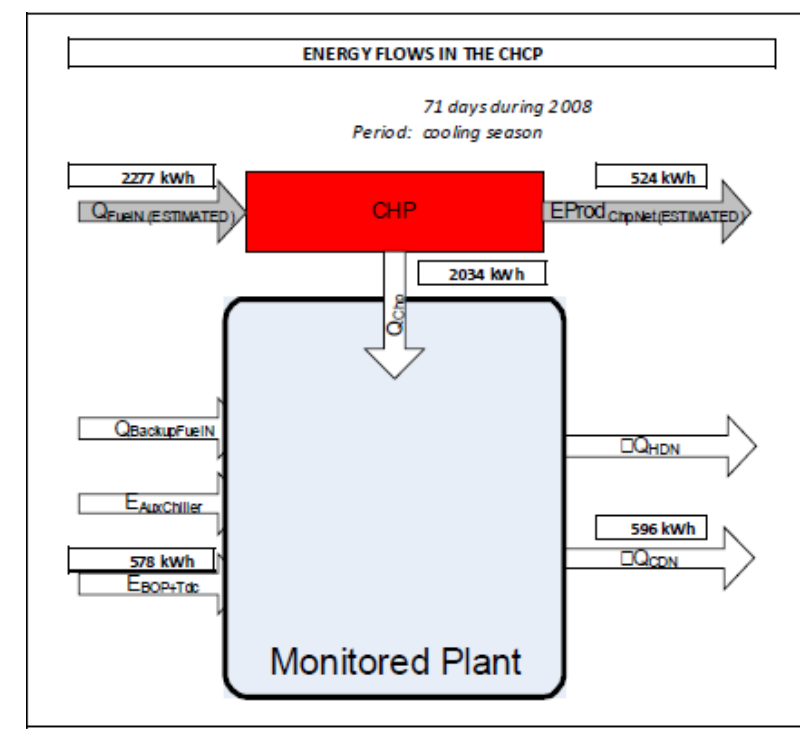

Figure A.3 Energy balance of the integrated system during summer (Nurenz, 2010)

\section{Project-2:}

\begin{tabular}{|l|l|}
\hline Project leader & Fernando Miguelez \\
& BESEL S.A. \\
& $\begin{array}{l}\text { Engineering Dept. } \\
\text { fmigulez@ besel.es }\end{array}$ \\
\hline Other partners involved & SERC \\
& ClimateWell ${ }^{\circledR}$ \\
& KTH \\
& FSKAB \\
\hline Location & Leganes, Spain, 2009 \\
\hline
\end{tabular}

This sub-project was installed in a recreation center in Lleganes, Spain. The system ran in August and September of 2009 (21 days altogether) in the cooling mode. It provided heating and cooling to the main hall of the recreation centre. In this project, a ClimateWell ${ }^{\circledR} 10$ unit was coupled with a natural gas fuelled Senertec Dachs $5.5 \mathrm{~kW}$ CHP unit. A bypass valve was installed between the feed line and return line which helps to charge the chiller in cold temperatures at the starting condition. The functional block diagram of the system is shown in Figure A.4 and a schematic diagram of the project is shown in Figure A.5. Figure A.6 shows the actual image of the installation. 


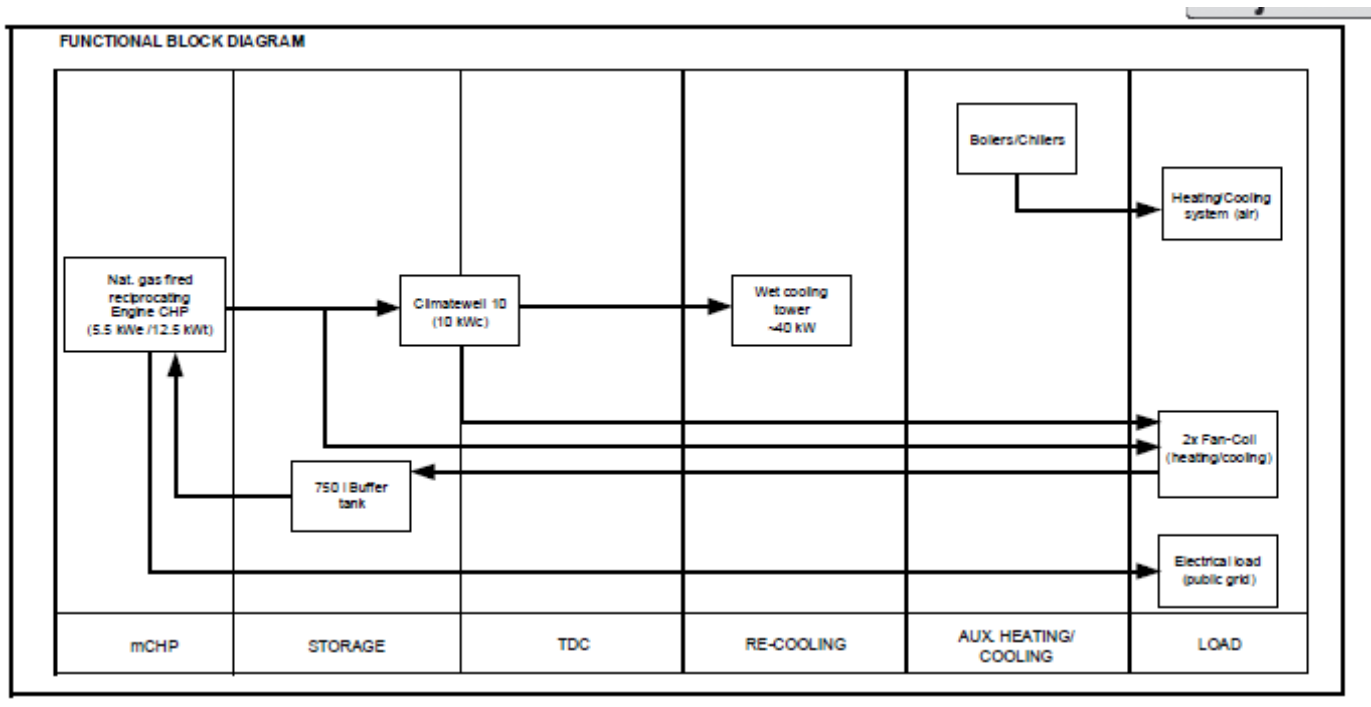

Figure A.4 Functional block diagram of Project-2 (Nurenz, 2010)

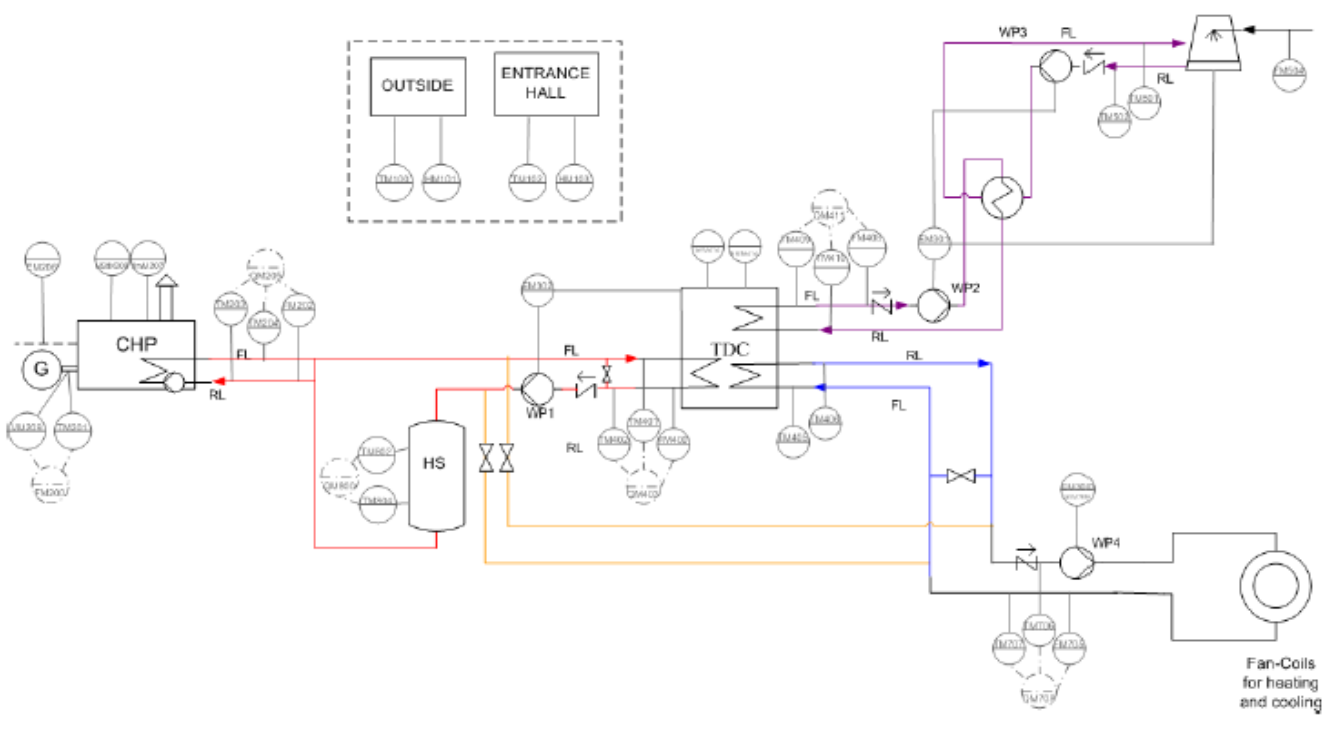

Figure A.5 Schematic diagram of Project-2 (Nurenz, 2010)

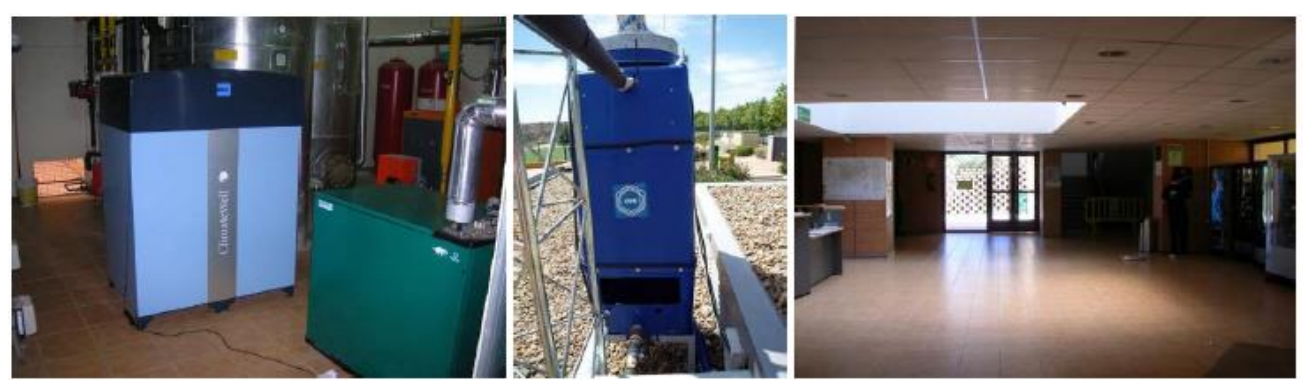

Figure A.6 Installation of ClimateWell ${ }^{\circledR} 10$ chiller in Project-2 (Nurenz, 2010) 
Performance and operation of the integrated system are listed in Table A.1.

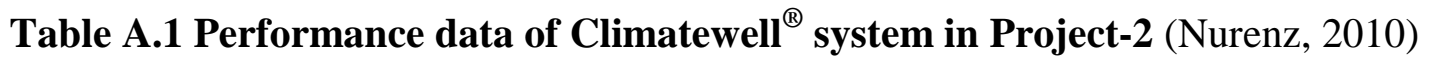

\begin{tabular}{|c|c|c|}
\hline Concept & Winter & Summer \\
\hline Gas consumption & $37900.43 \mathrm{kWh}$ & $8969.06 \mathrm{kWh}$ \\
\hline Heating & $21942.50 \mathrm{kWh}$ & $4998.36 \mathrm{kWh}$ \\
\hline Cooling & & $2676.34 \mathrm{kWh}$ \\
\hline Electrical Power & $9874.09 \mathrm{kWh}$ & $2445.96 \mathrm{kWh}$ \\
\hline Electric efficiency of CHP & $26.05 \%$ & $27.27 \%$ \\
\hline Thermal efficiency of CHP & $57.90 \%$ & $55.73 \%$ \\
\hline Overall efficiency of CHP & $83.95 \%$ & $83 \%$ \\
\hline COP of TDC & & $53.54 \%$ \\
\hline
\end{tabular}

During this Project, August $18^{\text {th }}$ was considered as a typical hot day. During this day, the average cooling power was $5.76 \mathrm{~kW}$, the maximum cooling power was $9.6 \mathrm{~kW}$ and the average cooling water flow rate was $46 \mathrm{l} / \mathrm{min}$. The cooling temperature had an average value of $17-18^{\circ} \mathrm{C}$ for the inlet loop and $12-13^{\circ} \mathrm{C}$ for the outlet loop (from the chiller side). Details about the project can be found at www.polysmart.org. 


\section{Appendix-B}

\section{Uncertainty of Sensors and Calibrators}

The accuracy levels of different sensors used in this project are listed in Table B.1.

Table B.1 Accuracy level of different sensors used (Tanha, 2011)

\begin{tabular}{|c|c|c|c|c|}
\hline Sensor name & Sensor type & Manufacturer & Model number & $\begin{array}{c}\text { Sensor } \\
\text { accuracy }\end{array}$ \\
\hline Turbine type flow rate & $\begin{array}{c}\text { Measure } \\
\text { liquid/water flow } \\
\text { rate }\end{array}$ & $\begin{array}{l}\text { Omega/Clark } \\
\text { Solution }\end{array}$ & CFT110 & $\pm 3.0 \%$ \\
\hline Metering flow switch & $\begin{array}{c}\text { Measure } \\
\text { liquid/water flow } \\
\text { rate }\end{array}$ & $\begin{array}{c}\text { Proteus } \\
\text { Industries Inc. }\end{array}$ & 800 Series & $\pm 0.5 \%$ \\
\hline $\begin{array}{l}\text { RTD sensor (Pt.-100, } \\
\text { directly immersed) }\end{array}$ & $\begin{array}{c}\text { Measure } \\
\text { Temperature }\end{array}$ & Omega & $\begin{array}{l}\text { PRTF-10-2-100-1/4-6- } \\
\text { E }\end{array}$ & $\pm 0.1 \%$ \\
\hline $\begin{array}{l}\text { RTD sensor (Pt.-100, } \\
\text { surface mount) }\end{array}$ & $\begin{array}{c}\text { Measure } \\
\text { Temperature }\end{array}$ & Omega & RTD-2-F3105-36-T-B & $\pm 0.12 \%$ \\
\hline $\begin{array}{c}\text { RTD sensor (Pt.-500, } \\
\text { directly immersed) }\end{array}$ & $\begin{array}{c}\text { Measure } \\
\text { Temperature }\end{array}$ & Kamstrup & 65-00-0DO-310 & N/A \\
\hline Gas mass flow meter & $\begin{array}{l}\text { Measure gas flow } \\
\text { rate }\end{array}$ & $\begin{array}{c}\text { SIERRA } \\
\text { Instruments }\end{array}$ & $\begin{array}{c}\text { 826-NX-OV1-PV1-V1- } \\
\text { T }\end{array}$ & $\pm 1.5 \%$ \\
\hline
\end{tabular}

Accuracy level of different calibrator used in this project are listed in Table B.2

Table B.2 Accuracy level of different calibrators used (Tanha, 2011)

\begin{tabular}{|c|c|c|c|c|}
\hline Calibrator name & Calibrator type & Manufacturer & Model number & $\begin{array}{c}\text { Calibrator } \\
\text { accuracy }\end{array}$ \\
\hline $\begin{array}{c}\text { Hand held dry- } \\
\text { well calibrator }\end{array}$ & $\begin{array}{c}\text { Calibrate } \\
\text { temperature sensor }\end{array}$ & Hart Scientific & $9102 \mathrm{~S}$ & $\pm 0.25 \%$ \\
\hline Micro calibrator & $\begin{array}{c}\text { Calibrate RTD, } \\
\text { thermocouple, mA, } \\
\mathrm{mV}, \text { pulse signal }\end{array}$ & $\begin{array}{c}\text { Eurotron } \\
\text { Instruments S.P.A. }\end{array}$ & $\begin{array}{c}\text { Microcal 20DPC } \\
\text { (Basic) }\end{array}$ & $\pm 0.02 \%$ \\
\hline
\end{tabular}




\section{Appendix-C}

\section{Properties of Propylene Glycol}

\section{C.1. Density of Propylene Glycol solution at different temperature}

\begin{tabular}{|c|c|c|c|c|c|c|c|c|}
\hline \multirow{2}{*}{$\begin{array}{c}\text { Temp. } \\
{ }^{\circ} \mathrm{C}\end{array}$} & \multicolumn{8}{|c|}{ Volume Percent Propylene Glycol } \\
\hline & $0 \%$ & $10 \%$ & $20 \%$ & $30 \%$ & $40 \%$ & $50 \%$ & $60 \%$ & $70 \%$ \\
\hline-35 & & & & & & & 1094.7 & 1104.7 \\
\hline-30 & & & & & & 1081.9 & 1092.8 & 1102.5 \\
\hline-25 & & & & & & 1080.2 & 1090.8 & 1100.2 \\
\hline-20 & & & & & 1066.6 & 1078.4 & 1088.7 & 1097.8 \\
\hline-15 & & & & & 1065.0 & 1076.5 & 1086.5 & 1095.3 \\
\hline-10 & & & & 1050.7 & 1063.3 & 1074.5 & 1084.2 & 1092.7 \\
\hline-5 & & & 1035.1 & 1049.2 & 1061.5 & 1072.4 & 1081.8 & 1089.9 \\
\hline 0 & & 1018.2 & 1033.8 & 1047.5 & 1059.5 & 1070.1 & 1079.3 & 1087.1 \\
\hline 5 & 1006.7 & 1017.0 & 1032.3 & 1045.7 & 1057.5 & 1067.8 & 1076.6 & 1084.2 \\
\hline 10 & 1004.3 & 1015.7 & 1030.6 & 1043.8 & 1055.3 & 1065.3 & 1073.9 & 1081.2 \\
\hline 15 & 1001.9 & 1014.2 & 1028.9 & 1041.8 & 1053.0 & 1062.7 & 1071.1 & 1078.1 \\
\hline 20 & 999.4 & 1012.6 & 1027.0 & 1039.6 & 1050.5 & 1060.0 & 1068.1 & 1074.9 \\
\hline 25 & 996.9 & 1010.9 & 1025.0 & 1037.4 & 1048.0 & 1057.2 & 1065.0 & 1071.5 \\
\hline 30 & 994.3 & 1009.1 & 1022.9 & 1035.0 & 1045.3 & 1054.3 & 1061.9 & 1068.1 \\
\hline 35 & 991.7 & 1007.2 & 1020.7 & 1032.5 & 1042.6 & 1051.3 & 1058.6 & 1064.6 \\
\hline 40 & 989.0 & 1005.1 & 1018.3 & 1029.8 & 1039.7 & 1048.1 & 1055.2 & 1061.0 \\
\hline 45 & 986.3 & 1002.9 & 1015.8 & 1027.1 & 1036.7 & 1044.9 & 1051.7 & 1057.3 \\
\hline 50 & 983.5 & 1000.6 & 1013.2 & 1024.2 & 1033.5 & 1041.5 & 1048.1 & 1053.4 \\
\hline 55 & 980.7 & 998.1 & 1010.5 & 1021.2 & 1030.3 & 1038.0 & 1044.4 & 1049.5 \\
\hline 60 & 977.8 & 995.5 & 1007.6 & 1018.1 & 1026.9 & 1034.5 & 1040.6 & 1045.5 \\
\hline 65 & 974.9 & 992.8 & 1004.6 & 1014.8 & 1023.5 & 1030.8 & 1036.7 & 1041.4 \\
\hline 70 & 971.9 & 990.0 & 1001.5 & 1011.5 & 1019.9 & 1026.9 & 1032.7 & 1037.2 \\
\hline 75 & 968.8 & 987.0 & 998.3 & 1008.0 & 1016.2 & 1023.0 & 1028.5 & 1032.8 \\
\hline 80 & 965.7 & 984.0 & 995.0 & 1004.4 & 1012.3 & 1019.0 & 1024.3 & 1028.4 \\
\hline 85 & 962.6 & 980.7 & 991.5 & 1000.7 & 1008.4 & 1014.8 & 1020.0 & 1023.9 \\
\hline 90 & 959.3 & 977.4 & 987.9 & $\begin{array}{l}996.8 \\
\end{array}$ & 1004.3 & 1010.5 & 1015.5 & 1019.3 \\
\hline 95 & 956.0 & 974.0 & 984.2 & 992.9 & 1000.1 & 1006.2 & 1010.9 & 1014.6 \\
\hline 100 & 952.6 & 970.4 & 980.3 & 988.8 & 995.8 & 1001.7 & 1006.3 & 1009.7 \\
\hline 105 & 949.2 & 966.7 & 976.3 & 984.6 & 991.4 & 997.1 & 1001.5 & 1004.8 \\
\hline 110 & 945.7 & 962.8 & 972.3 & 980.2 & 986.9 & 992.3 & 996.6 & 999.8 \\
\hline 115 & 942.1 & 958.9 & 968.0 & 975.8 & 982.2 & 987.5 & 991.6 & 994.7 \\
\hline 120 & 938.5 & 954.8 & 963.7 & 971.2 & 977.5 & 982.6 & 986.5 & 989.4 \\
\hline 125 & 934.7 & 950.6 & 959.2 & 966.5 & 972.6 & 977.5 & 981.3 & 984.1 \\
\hline 130 & 930.9 & 946.3 & 954.7 & 961.7 & 967.6 & 972.3 & 976.0 & 978.7 \\
\hline 135 & 927.1 & 941.8 & 949.9 & 956.8 & 962.5 & 967.1 & 970.6 & 973.1 \\
\hline \begin{tabular}{|l|}
140 \\
\end{tabular} & 923.1 & 937.2 & 945.1 & 951.8 & 957.2 & 961.7 & 965.1 & 967.5 \\
\hline 145 & 919.1 & 932.5 & 940.2 & 946.6 & 951.9 & 956.2 & 959.5 & 961.8 \\
\hline 150 & 914.9 & 927.7 & 935.1 & 941.3 & 946.4 & 950.5 & 953.7 & 956.0 \\
\hline 155 & 910.7 & 922.7 & 929.9 & 935.9 & 940.8 & 944.8 & 947.9 & 950.0 \\
\hline 160 & 906.4 & 917.7 & 924.5 & 930.3 & 935.1 & 939.0 & 941.9 & 944.0 \\
\hline
\end{tabular}

= At or above atmospheric boiling point.

Note: density is expressed in $\left(\mathrm{kg} / \mathrm{m}^{3}\right)$

To determine specific gravity, divide the density of the fluid by water density at $20^{\circ} \mathrm{C}$ 


\section{C.2. Specific heat of Propylene Glycol solution at different temperature}

\begin{tabular}{|c|c|c|c|c|c|c|c|c|c|c|}
\hline \multirow{2}{*}{$\begin{array}{l}\text { Temp. } \\
{ }^{\circ} \mathrm{C}\end{array}$} & \multicolumn{10}{|c|}{ Volume Percent Propylene Glycol } \\
\hline & $0 \%$ & $10 \%$ & $20 \%$ & $30 \%$ & $40 \%$ & $50 \%$ & $60 \%$ & $70 \%$ & $80 \%$ & $90 \%$ \\
\hline-35 & & & & & & & 3.096 & 2.843 & 2.572 & 2.264 \\
\hline-30 & & & & & & 3.339 & 3.118 & 2.868 & 2.600 & 2.295 \\
\hline-25 & & & & & & 3.358 & 3.140 & 2.893 & 2.627 & 2.326 \\
\hline-20 & & & & & 3.569 & 3.378 & 3.162 & 2.918 & 2.655 & 2.356 \\
\hline-15 & & & & & 3.586 & 3.397 & 3.184 & 2.943 & 2.683 & 2.387 \\
\hline-10 & & & & 3.765 & 3.603 & 3.416 & 3.206 & 2.968 & 2.710 & 2.417 \\
\hline-5 & & & 3.918 & 3.779 & 3.619 & 3.435 & 3.228 & 2.993 & 2.738 & 2.448 \\
\hline 0 & & 4.042 & 3.929 & 3.793 & 3.636 & 3.455 & 3.250 & 3.018 & 2.766 & 2.478 \\
\hline 5 & 4.229 & 4.050 & 3.940 & 3.807 & 3.652 & 3.474 & 3.272 & 3.042 & 2.793 & 2.509 \\
\hline 10 & 4.195 & 4.058 & 3.951 & 3.820 & 3.669 & 3.493 & 3.295 & 3.067 & 2.821 & 2.539 \\
\hline 15 & 4.168 & 4.067 & 3.962 & 3.834 & 3.685 & 3.513 & 3.317 & 3.092 & 2.849 & 2.570 \\
\hline 20 & 4.147 & 4.075 & 3.973 & 3.848 & 3.702 & 3.532 & 3.339 & 3.117 & 2.876 & 2.600 \\
\hline 25 & 4.132 & 4.083 & 3.983 & 3.862 & 3.718 & 3.551 & 3.361 & 3.142 & 2.904 & 2.631 \\
\hline 30 & 4.121 & 4.091 & 3.994 & 3.875 & 3.735 & 3.570 & 3.383 & 3.167 & 2.931 & 2.661 \\
\hline 35 & 4.115 & 4.099 & 4.005 & 3.889 & 3.751 & 3.590 & 3.405 & 3.192 & 2.959 & 2.692 \\
\hline 40 & 4.114 & 4.107 & 4.016 & 3.903 & 3.768 & 3.609 & 3.427 & 3.217 & 2.987 & 2.723 \\
\hline 45 & 4.115 & 4.115 & 4.027 & 3.917 & 3.784 & 3.628 & 3.449 & 3.242 & 3.014 & 2.753 \\
\hline 50 & 4.120 & 4.123 & 4.038 & 3.930 & 3.801 & 3.648 & 3.471 & 3.266 & 3.042 & 2.784 \\
\hline 55 & 4.128 & 4.131 & 4.049 & 3.944 & 3.817 & 3.667 & 3.493 & 3.291 & 3.070 & 2.814 \\
\hline 60 & 4.138 & 4.139 & 4.060 & 3.958 & 3.834 & 3.686 & 3.515 & 3.316 & 3.097 & 2.845 \\
\hline 65 & 4.150 & 4.147 & 4.071 & 3.972 & 3.850 & 3.706 & 3.537 & 3.341 & 3.125 & 2.875 \\
\hline 70 & 4.164 & 4.155 & 4.082 & 3.985 & 3.867 & 3.725 & 3.559 & 3.366 & 3.153 & 2.906 \\
\hline 75 & 4.179 & 4.163 & 4.093 & 3.999 & 3.883 & 3.744 & 3.581 & 3.391 & 3.180 & 2.936 \\
\hline 80 & 4.196 & 4.171 & 4.104 & 4.013 & 3.900 & 3.763 & 3.603 & 3.416 & 3.208 & 2.967 \\
\hline 85 & 4.213 & 4.179 & 4.115 & 4.027 & 3.916 & 3.783 & 3.625 & 3.441 & 3.236 & 2.997 \\
\hline 90 & 4.231 & 4.187 & 4.126 & 4.040 & 3.933 & 3.802 & 3.647 & 3.465 & 3.263 & 3.028 \\
\hline 95 & 4.249 & 4.195 & 4.136 & 4.054 & 3.949 & 3.821 & 3.670 & 3.490 & 3.291 & 3.058 \\
\hline 100 & 4.267 & 4.203 & 4.147 & 4.068 & 3.966 & 3.841 & 3.692 & 3.515 & 3.319 & 3.089 \\
\hline 105 & 4.285 & 4.211 & 4.158 & 4.082 & 3.982 & 3.860 & 3.714 & 3.540 & 3.346 & 3.119 \\
\hline 110 & 4.303 & 4.219 & 4.169 & 4.095 & 3.999 & 3.879 & 3.736 & 3.565 & 3.374 & 3.150 \\
\hline 115 & 4.321 & 4.227 & 4.180 & 4.109 & 4.015 & 3.898 & 3.758 & 3.590 & 3.402 & 3.181 \\
\hline 120 & 4.338 & 4.235 & 4.191 & 4.123 & 4.032 & 3.918 & 3.780 & 3.615 & 3.429 & 3.211 \\
\hline
\end{tabular}

$=$ At or above atmospheric boiling point.

Note: Specific Heat is expressed in $(\mathrm{J} / \mathrm{kg} . \mathrm{K})$ 


\section{References}

Accacia, M., Denntice, d., \& Sasso, M. (2003). Micro-Combined Heat and Power in residential and Light Commercial Applications. Applied Thermal Engineering , 23, 1247-1259.

Aguilar, A., White, D., \& Ryan, D. (2005). Domestic Hot Water Heating and Water Heater Energy Consumption in Canada. CBEEDAC 2005-RP-02.

ASHRAE 1999. (1999). Chapter-39, Building Energy Monitoring. Atlanta: Communications and Publications Publisher.

ASHRAE 2000. (2000). Chapter - 20, Humidifiers. Atlanta: Communications and Publications Publisher. ASHRAE. (1999). Building Energy Monitoring . Atlanta: Communications and Publications.

ASHRAE Guideline 2. (2005). Engineering Analysis of Experimental Data. Atlanta, USA: ASHRAE.

ASHRAE Guideline 2-2005. Engineering Analysis of Experimental Data. Atlanta, USA: ASHRAE.

Aussant, C., Fung, A., Ugursal, V., \& Taherian, H. (2009). Residential application of internal combustion engine based cogeneration in cold climate-Canada. Energy and Buildings , 41, 1288-1298.

Bales, C. (2000). modeling of Commercial Absorption Heat-pump with Internal Storage. Borlange, Sweeden: Hogskolan, Dalarna.

Baltus, C., Eikelboom, J., \& Van-Zolingen, R. (1997). Analytical Monitoring of Losses in PV Systems. 14th European Photovoltaic Solar Energy Conference. Barcelona.

Barua, R. (2010). Assessment and Energy Benchmarking for Two Archetype Sustainable Houses Through Comprehensive Long Term Monitoring. Toronto: Ryerson University, MASc thesis.

Barua, R., Zhang, D., \& Fung, A. (2010). Analysis of Energy Performance of Archetype Sustainabe House at Kortright Center. International High performance Building Conference.

Barua, R., Zhang, D., \& Fung, A. (2010). Analysis of Energy Performance of the Sustainable Archetype House at Kortright Centre. 1st International High performance Buildings Conference at Purdue University (pp. 3482 (1-8)). Indiana: Compressor/Refrigeration \& Air Conditioning/High Performance Buildings Conferences at Purdue.

Bejan, A. (1982). Entropy Generation through Heat and Flow. New York, USA: John Wiley \& Sons.

Bejan, A., Vadasz, P., \& Kroger, D. (1999). Energy and Environment. Boston, USA.: Kluwer Academic Publisher.

Bernier, M., Delisle, V., Picard, D., \& Kummert, M. (2004). On the combined effect of wastewater heat recovery and solar domestic hot water heating. Canadian Solar Buildings Conference. Montreal, QC. 
Bernotat, K., \& Sandberg, T. (2004). Biomass Fired Small Scale CHPs in Sweden and the Basic Statics: A Case Study on the Potential of Clustard Dweelings. Biomass and Bioenergy , 27, 521-530.

Bian, J., Radermacher, R., \& Moran, D. (June 22-25, 2005). Transient Simulatiion of Absorption Chiller in a CHP System. International Sorption Heat Pump Conference. Denver CO, USA.

Biaou, A., \& Bernier, M. (2005). Domestic Hot Water Heating in Zero Net Energy Homes. 9th International IBPSA Conference, (pp. pp.63-70). Montreal, Canada.

Biological Science Institute. (2002). Research Science. Retrieved 07 12, 2010, from Propagation of Errors in Calculation:

http://www.ferris.edu/htmls/colleges/artsands/biology/researchscience/SIPropagationOfErrors.cfm

Boies, A., \& Homan, K. (2008). Improving Discharge characteristics of Indirect Integral Collectpr Storage systems with Multi-element Storage. ASME Journal of Solar Energy Engineering , 130.

Borage, D., Colmenar, A., Castro, M., Martin, S., \& Sancristobal, E. (2011). Exergy Efficiency Analysis in Buildings Climatized with LiCl-H2O cooling. Energy and Buildings , 43, 3161-3172.

Bronson, T. (2003). Combined Heating, Cooling and Power Technologies. GTI/NICOR Combined Heat and Power .

California Energy Commission. (2001). A Guide to Photovoltaic (PV) System Design and Installation. Sacramento, California: Energy Technology Development Division.

California Energy Commission. (2006). Appliance Efficiency Regulations. CEC-400-2006-002-Rev2.

Canada Gazette. (2004). Energy Efficiency Act: Regulations Amending the Energy Efficiency Regulations. Vol. 138, No.19.

Carbon Trust. (2005). The Carbon Trust's Small-scale CHP Field Trial Update. London, UK.: Carbon Trust, UK.

Christian, J., Richards, L., Childs, P., Atchley, J., \& Moon, H. (2006). Energy Efficiency, SIPS, Geothermal, and Solar PV Used in Near Zero-Energy House. ASHRAE Transactions , 275-284.

ClimateWell. (2008, 02 29). Product Description ClimateWell-10, ver 09/03 EN1 . ClomateWell.

ClimateWell. (2010). ClimateWell Solar Chiller-Installation Manual. Sweeden: ClimateWell.

ClimateWell. (2009). Design Guideline for Solar Cooling. v9 , 32.1 EN. Sweeden: ClimateWell.

ClimateWell Solar Chiller-Installation Manual. (2010). Sweeden: ClimateWell.

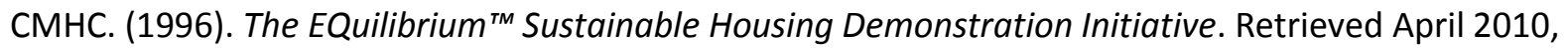
from Canada Mortgage and Housing Corporation: http://www.cmhcschl.gc.ca/en/co/maho/yohoyohe/heho/eqho/eqho_002.cfm 
Cohen, J. (2010). Mattamy Homes Green Initiative Project: Phase II - Mechanical System Performance Analysis. Toronto: Ryerson University, Department of Architectural Sciences.

Collins, M. (2009). Effectiveness Testing of PowerPipe ${ }^{\text {TM }}$ Drain Water Heat Recovery Systems. Solar Thermal Research Laboratory. Waterloo: University of Waterloo.

Conde, M. (2004). Properties of Aquas Solution of Lithium and calsium Chlorides: Formulations for Use in Air-conditioning Equipment Design. International Journal of Thermal Science , 43 (4).

Cruickshank, C. (2009). Evalution of a Stratified Multi-tank Thermal Storage for Solar Heating Applications. Queen's University, Mechanical and Materials Engineering. Kingston, Ontario, Canada: Queen's University, PhD thesis.

Cruickshank, C., \& Harrison, S. (2006). Analysis of Modular Thermal Storage for Solar Heating Systems. Proceedings of the Joint Conference of the Canadian Solar Buildings Research Network and Solar Energy Society of Canada Inc. (SESCI). Montreal, Quebec: SESCI.

Cruickshank, C., \& Harrison, S. (2006). Experimental Characterization of a Natural Convection Heat Exchanger for Solar Domestic Hot Water Systems. International Solar Energy Conference. Denver, Colorado, USA.

Dembo, A., Fung, A., NG, R., \& Pyrka, A. (2010). The Archetype Sustainable House: Investigating its Potentials to Achieving the Net-Zero Energy Status Based on the Results of a Detailed Energy Audit. International High Performance Buildings Conference. Purdue, Indiana.

Deng, J., Wang, R., \& Han, G. (2011). A Review of Thermally Activated cooling Technologies for Combined cooling, Heating and Power Systems. Progress in Energy and Combustion Science , 37, 172203.

Design Guideline for Solar Cooling. (2009). v9 , 32.1 EN. Sweeden: ClimateWell.

DOE. (2011b). Retrieved April 2011, from www.energysavers.gov.

DOE. (2001). Heat Recovery from Wastewater Using Gravity-Film Heat Exchanger. Retrieved February 2011, from www.gfxtechnology.com: http://gfxtechnology.com/Femp.pdf

Dong, W., Lucentini, M., \& Nasp, V. (2000). The Potential market Analysis of a CHCP System. Intersociety Energy Conversion Engineering Conference and Exhibition. Nevada, Las Vagas, USA: IECEC.

Druck, H., Heidemann, W., \& Müller-Steinhagen, H. (2004). Comparison Test of Thermal Solar Systems for Domestic Hot Water Preparation and Space Heating. EuroSun2004. Freiburg, Germany.

Dumont, R. (2008). The Factor 9 Home: A New Prairie Approach Monitoring Final Report. Saskatoon: Saskatchewan Research Council.

Ecologix. (2011-2012). Ecologix-Zone Comfort Air Handlers. Retrieved 02 25, 2013, from Ecologix: http://www.ecologix.ca/products/product-selection-tool/SpecSheet?productcategory=1\&modeltype=4 
Efficiency Valuation Organization (EVO). (2007). Concepts and Options for Determine Energy and Water Savings (IPMVP). San Francisco, California: International Performance Measurement and Verification Protocol.

Ekrami, N., Hasib, Z., Lele, P., Fung, A., Dworkin, S., \& Naylor, D. (2012). Feasibility Study of Residential Tri-generation System based on LiCl-water Absorption Chiller. Manitoba, canada: Canadian Society of Mechanical Engineers (CSME).

Elovitz, K. M. (2001). Hydronic Heating: Two Systems Compared. ASHRAE Journal , 36-42.

Entchev, E., Gusdorf, J., Swinton, M., Bell, M., Szadkowski, F., Kalbfleisch, W., et al. (2004). Microgeneration technology assessment for housing technology. Energy and Buildings, Volume: 36, 925-931.

Environment Canada. (2011). Fuel Combustion. Retrieved November 2011, from www.ec.gc.ca.

Environment Canada. (2000). National Climate Data and information Archive. Retrieved November 2011, from www.climate.weatheroffice.gc.ca.

ES Renewables Ltd. (2011). Retrieved April 2011, from

http://esrenewables.tech.officelive.com/SolarWaterHeating.aspx

Eslami-nejad, P., \& Bernier, M. (2009). Impact of Grey Water Heat Recovery on the Electrical Demand of Domestic Hot Water Heaters. 11th International IBPSA Conference, (pp. 681-687). Glascow, Scotland.

European Commission Directorate General for Energy and Transport. (2004). Basic European and International Standards on Solar Thermal Glazed Collectors \& Solar Domestic Hot Water Systems. Athens, Greece: Exergia S.A.

European Parliament of the Council. (2000, June 29). Regulation (ec) no 2037/2000.

European Union. (2008). Polygeneration with Advanced Small and Medium Scale Thermally Driven Chiller.

Exhibition Place. (2009). SolarCity: Horse Palace Photovoltaic Pilot Project Findings Report. Toronto: Exhibition Place.

Fan, Y., Luo, L., \& Souyri, B. (2007). Review of Solar Sorption Technologies. Renewable and Sustainable Energy Reviews , 11, 1758-1775.

Feng, J., Megerian, S., \& Potkonjak, M. (2003). Model-Based Calibration for Sensor Networks. IEEE Xplore , 737-742.

Ferguson, A. (2006). Calibration of the IEA/ECBCS Annex 42 Combustion Based CHP Model: WhisperTech Stirling CHP Unit. NRCan Internal Report, Natural Resources Canada (NRCan).

Ferguson, A., \& Kelly, N. (2006). A Generic Model Specification for Combustion-based Residential CHP Devices. IEA. 
Frangopoulos. (March 2002). The European Education Tool on Energy-Efficiency through the Use of Cogeneration. EDUCOGEN .

Fung, A., \& Gordon, C. (2009). Hourly Emission Factors from the Electricity Generation Sector- A Tool for Analyzing the Imoact of Renewable Technologies in Ontario. Canadian Society for Mechanical Engineering , 105-118.

Gea, Y., Tassou, S., Chaer, I., \& suguartha, N. (2009). erformance Evaluatiion of a Tri-generation System with Simulation and Experiment. Applied Energy, 86, 2317-2316.

Gill, G., \& Fung, A. (2011). Energy and Environmental Analysis of Residential Hot Water Systems; A Study for Ontario, Canada. ASHRAE Transactions, Vol. 117, Part 2, 506-520.

Godefroy, J., Boukhanouf, R., \& Riffat, S. (2007). Design, Testing and mathematical Modeling of Smallscale CHP and Cooling System (small CHP-ejector Tri-generation). Applied Thermal Engineering , 27, 6877.

Guilleminot, J., Poyelle, F., \& Meunier, F. (1998). Experimental Results and Modeling Tests of an Adsorptive air-conditioning Unit. ASHRAE Trans. , 104, 1543-1551.

Hasib, Z., Ekrami, N., Lele, P., Dworkin, S., Fung, A., \& Naylor, D. (2012). Residentail Micro Tri-generation System Based on Thermo Chemical Accumulator (TCA). Sustainable Energy Technologies (SET)-2012. Vancouver: SET.

Hawkes, A., \& Leach, M. (2007). Cost Effective Operating Strategy for Residential Micro Combined Heat, Power and Energy. Energy and Environment, 32, 711-723.

Hendron, R. (2008). Building America Research Benchmark Definition. Colorado: National Renewable Energy Laboratory.

Hendron, R., \& Burch, J. (2007). Development of Standardized Domestic Hot Water Event Schedules for Residential Buildings. Energy Sustainability. Long Beach, CA: National Renewable Energy Laboratory.

Herold, K., \& Radermacher, L. (1989, August). Absorption Heat pump. Mech. Engg. , 68-73.

Hewitt, N., \& Henderson, P. (2001). Drainwater Heat Recovery System - An Energy Conservation Project. Coleraine, Northern Ireland.

Holemberg, P., \& Berntsson, T. (1990). Alternative working Fluids in Heat Transformers. ASHRAE Trans. (96), 1582-96.

Huber, C. (1998). Fittrn/DF-TRNSYS parameter identification with DF for windows 95/NT . Retrieved from www.solarenergy.ch

Huppman, G. (2000). European Fuel Cell news. Decentralized Combined Power and Heat Generation: The MTU direct Fuel Cell-Hot Module , 7 (2), pp. 17-23. 
Iloeje, O., Ndili, A., \& Enibe, S. (1995). Computer Simulation of Cac/2 Solid-adsorption Solar Refrigerator. Energy (Oxford).

International Absorption Society. (2012, May 12). Retrieved 2013, from Absorption and Adsorption : http://ias.vub.ac.be/What\%20is\%20adsorption.html

Jordan, U., \& Vajen, K. (2001). Realistic Domestic Hot Water Profiles in Different Time Scales. Marburg: Universitat Marburg.

Kalb, C., \& Seader, J. (1974). Fully developed viscous flow heat transfer in curved circular tubes with uniform wall temperature. AlchE Journal , 20(2), 340-346.

Kalz, D., Herkel, S., \& Wagner, A. (2009). The impact of auxiliary energy on the efficiency of the heating and cooling system: Monitoring of low-energy buildings. ELSEVIER, Building and Energy , 1019-1030.

Kim, Y., \& Seo, T. (2007). Thermal Performances Comparisons of the Glass Evacuated Tube Solar Collectors With Shapes of Absorber Tube. Renewable Energy (32), 772-795.

King, D., Boyson, W., \& Kratochvil, J. (2002). Analysis of factors influencing the annual energy production of photovoltaic systems. Conference Record of the 29the IEEE Photovoltaic Specialists Conference 2002 (pp. 1356-61). IEEE Xplore.

Klein, D., \& Villarroel, M. (2006). High Efficieny Combined Heating, Cooling and Power Technologies. EIC Climate Change Conference. Ottawa, Canada: IEEE.

Klein, S. B. (2004). TRNSYS 16 - Transient Simulation Studio. SEL, University of Wisconsin Madison, Madison WI, USA.

Knier, G. (2002). How do Photovoltaics Work. Science@NASA Headline News.

Knight, I., Kreutzer, N., Manning, M., Swinton, M., \& Ribberink, H. (2007). European and Canadian nonHVAC Electric and DHW Load Profiles for Use in Simulating the Performance of Residential Cogeneration Systems. International Energy Agency (IEA Annex 42).

Knight, I., Ugursal, I., \& Beausoleil-Morrison, I. (2005). Residential Co-generation Systems: A Review of The Current Technologies. International Energy Agency.

Kong, X., Wang, J., Huang, X., Wu, D., \& Xu, Y. (2005). Experimental Investigation of a Micro-combined Cooling, Heating and Power System Driven by Gas Turbine. International Journal of Refrigeration , 28, 977-987.

Kong, X., Wang, R., \& Huang, X. (2009). Energy Efficiency and Economic Feasibility of CHCP Driven by Stirling Engines. Energy Conversion and Management, 86, 2317-2326.

Kong, X., Wang, R., \& Huang, X. (2005). Energy Optimization Model for a CCHP System with Available Gas Turbines. Applied Thermal Engineering , 25, 377-391. 
Kravchenko, V. (1966). Empirical Equation Derived for Temperature Dependence of Density of Heavy Water. Springer New York , 212.

Kuphaldt, T. R. (2009). Instrumentation, Lessons In Industrial. In C. I. Calibration, 13.9.2 Temperature Standards (pp. 353-355). San Francisco: Creative Commons, California, 94105, USA.

Laughton, C. (2010). Solar Domestic Water Heating. Washington, DC: Earthscan.

Legget, R., \& Peckover, F. (December,1949). Soil Temperature Studies - A Progress Report. The 29th Annual Meeting of the Highway Research Board, (pp. 434-445). USA.

London Economics LLD. (2011, March). Independent Power Producers Society of Alberta. Retrieved November 2011, from www.ippsa.com.

Mahjouri, F. (2010). Vacuum Tube Liquid-Vapor (Heat-Pipe) Collectors. Retrieved 05 08, 2010, from www.thermotechs.com: http://www.thermotechs.com/Downloads/Vacuum\%20Tube\%20Paper.pdf

Maiya, R. S. (1998). Thermodynamic Comparison of Water-based Working Fluid Combinations for Vapour Absorption System. Applied Thermal Engineering , 8 (7), 553-568.

Marrone, J. (2007, March 2). National view of activities leading to Net Zero Energy Home Constructiona perspective from Natural Resources Canada. Ottowa, Ontario, Canada.

Mather, D., Hollands, K., \& Wright, J. (2002). Single and Multi-tank Energy storage for solar heating systems: Fundamentals. Solar Energy (73), 3-13.

Matrosov, Y., Butovsky, I., \& Watson, R. (1994). Case studies of energy consumption in residential buildings in Russia's middle belt area. Energy and Building , 231-241.

Merlin, E. (2002). Fluides frigorigenes: La reglementation se renforce.

Merrigan, T., \& Parker, D. (1990, August). Electrical Use, Efficiency, and Peak Demand of Electric Resistance, Heat Pump, Desuperheater, and Solar Hot Water Systems. American Council for an Energy Efficient Economy, Asilomar Conference Center, Pacific Grove, CA.

Miller, G., Gilmour, B., Myrans, I., Lang-Bismillah, A., Cordeiro, I., Jessop, T., et al. (2008). Sustainable Building Canada on the Move. Toronto: Canadian Urban Institute.

Minciuc, E., Corre, O., Athanasovici, V., \& Tazerout, M. (2003a). Fuel Savings and CO2 Emission for Trigeneration Systems. Applied Thermal Engineering , 23, 1391-1405.

Minciuc, E., Corre, O., Athanasovici, V., Tazerout, M., \& Bitir, I. (2003b). Thermodynamic Analysis of Trigeneration with Absorption Chilling Machine. Applied Thermal engineering , 23, 1391-1405.

Mroz, T. (2006). Thermodynamic and Economic Performance of the LiBr-H2O Single Effect Chiller. Applied Thermal Engineering , 2103-2109. 
NAHB Research Center. (2002). Domestic Hot Water System Modeling For the Design of Energy Efficient Systems. Upper Marlboro, MD.

National Energy Technology Laboratory. (2009). Recovery Act: Advanced Energy Efficient Building Technologies. U.S. Department of Energy.

Nelson, F., Mago, P., \& Charma, L. (2009). Analysis of Cooling, Heating and Power Systems Based on Site Energy Consumption. Applied Energy, 86, 928-932.

Newton, B. (1995). Modeling of Solar Storage tanks. University of Wisconsin. Wisconsin, madison: University of Wisconsin.

NIST. (2009, July 02). National Institute of Standards and Technology. Retrieved July 02, 2009, from www.nist.gov: http://ts.nist.gov/MeasurementServices/Calibrations/flow.cfm\#18020C

Nordlander, S. a. (2007). TRNSYS Type 215 - Climatewell 10 Barrel Model Description. Högskolan Dalarna, SERC. Borlänge, Sweden: Högskolan Dalarna.

NRCan. (2007). (Natural Resources Canada, National Energy Use Database, 1990 to 2007) Retrieved 2010, from http://www.nrcan.gc.ca: http://www.nrcan.gc.ca

NRCan. (2009, May). Retrieved April 2010, from http://www.nrcan.gc.ca

NRCan. (2009, September). Energy Efficiency Trends in Canada: 1990 to 2007. Retrieved March 2011, from Natural Resources Canada: http://oee.nrcan.gc.ca/publications/statistics/trends09/pdf/trends.pdf Nurenz, T. (2010). Technology and Literature Review. European Union. Polysmart.

Olesen, B. W. (2002). Radiant Floor Heating in Theory and Practice. ASHRAE Journal , 19-24.

Olofsson, P. (2009). Design Guideline for Solar Cooling. ClimateWell AB.

Olsson, R., Kaarebring, M., \& Jonsson, S. (2000). Patent No. W00037864.

Onovwiona, H., \& Ugursal, V. (2004). Residential cogeneration systems: review of the current technology. Renewable \& Sustainable Energy Reviews , 1-43.

Onovwiona, H., Ugursal, V., \& Fung, A. (2007). Modeling of internal combustion engine based cogeneration systems for residential applications. Applied Thermal Engineering , 27, 848-861.

Onovwionaa, H., \& Ugursal, V. (2004). Residential cogeneration systems: review of the current technology. Renewable and Sustainable Energy Reviews , 1-43.

Padfield, T. (1996). Equations describing the physical properties of moist air. Retrieved December 2008, from The physics of the museum environment: http://www.natmus.dk/cons/tp/atmcalc/atmoclc1.htm Paepe, M., Herdt, P., \& Mertens, D. (2006). Micto CHP systems for residential Applications. Energy Conversion Management , 47, 3435-3446. 
Parker, D. (2003). Research highlights from a large scale residential monitoring study in a hot climate. Energy and Buildings, 35, 863-876.

Parker, D. S. (1989). Thermal Performance Monitoring Results from the Residential Standards Demonstration Program. Energy and Buildings , 231-248.

Parker, D. S. (2009). Very low energy homes in the United States: Perspectives on performance from measured data. Energy and Buildings , 512-520.

Peacock, A., \& Newborough, M. (2005). Impact of Micro-CHP Systems on Domestic Sector CO2 Emissions. Applied Thermal Engineering , 25, 2653-2676.

Pengra, D., \& Dillman, L. (2009). Notes on Data Analysis and Experimental Uncertainty. Ohio Wesleyan University.

Perlman, M., \& Mills, B. (1985). Development of Residential Hot Water Use Patterns. ASHRAE Transactions , 657-679.

Peuser, F., Remmers, K.-H., \& Schnauss, M. (2002). Solar Thermal systems, Successful Planning and Construction. London, UK.: James \& James.

Piacentino, A., \& Cardona, F. (2007). On Thermoeconomics of Energy systems at variable Load Conditions. Energy Conversion and management , 2341-2355.

Picard, D., Bernier, M., \& Charneux, R. (2007). Domestic Hot Water Production in a Net Zero Energy Triplex in Montreal. 2nd Canadian Solar Buildings Conference, (pp. pp.1-8). Calgary.

Pilatowsky, R., Romeo, C., Saza, C., Gamboa, S., Rivera, W., Sebastian, P., et al. (2007). Simulation of an Air-conditioning Absorption Refrigeration system in a Co-generation Process combining a Proton Exchange membrane Fuel Cell. Journal of Hydrozen Energy, 32, 3174-3182.

Plura, S., Kren, C., \& Schweigler, C. (June 22-24, 2005). System Concept for Efficient and Flexible TriGeneration. International sorption Heat Pump Conference. Denver CO, USA.

Podesser, E., Beyer, H., \& Fankhauser, G. (1998). Small Scale Combined Heat and Power Production with Stirling Engines in Biomass Furnaces. IEA.

Prez-Blanco H. (1984). Absorption Heat Pump Performance for Different Types of Solution. International Journal of Refrigeration , 7 (2), 115-122.

Proskiw, G. (1995). Design and Analysis of a Residential Grey-Water Heat Recovery System. Prepared for Natural Resources Canada and Centra Gas Manitoba, Winnipeg, Manitoba.

Proskiw, G. (1998). Technology Profile: Residential Grey-Water Heat Recovery Systems. Prepared for Natural Resources Canada and Manitoba Hydro Electrical Board, Winnipeg, Manitoba. 
Psychrometric Calculations. (2008). Material properties. Retrieved December 2008, from Sugar Engineers: http://www.sugartech.co.za/psychro/index.php

Queen's University Applied Sustainability Research Group. (2010, June 17 ). Effects of snow on photovoltaic performance. Retrieved June 19, 2010, from Appropedia:

http://www.appropedia.org/Effects_of_snow_on_photovoltaic_performance

Ragoonanan, V., Davidson, J., Homan, K., \& Mantell, S. (2006). The Benefit of Dividing an Indirect Thermal Storage into Two compartments: Discharge Experiments. Solar Energy , 8 (1), 18-31.

Ren, H., \& Gao, W. (2009). Economic and enviornmental evaluation of micro CHP systems with different operating modes for residential buildings in Japan. Energy and Buildings, Volume: 42 , 853-861.

Roth, K., \& Brodrick, J. (2008). Home Energy Displays. ASHRAE Journal , 136-138.

Sekulic, D., \& Krane, R. (1992). The Use of Multiple Storage Elements to Improve the Second Law Efficiency of a Thermal Energy Storage System, Part-2: Completion of the Analysis and Presentaion of Results. ECOS 92 on Efficiency, Costs, Optimization and Simulation of Energy Systems (pp. 67-72). ASME.

Sherman, I. S. (2007). Humidity Implications for Meeting Residential Ventilation Requirements.

California: Environmental Energy Technologies Division, Ernest Orlando Lawrance Berkley National Laboratory.

Solar Buildings Research Network (SBRN). (2010, May 9). Retrieved May 9, 2010, from www.solarbuildings.ca: http://www.solarbuildings.ca/en/projects_3

Solar Energy Laboratory of University of Wisconsin. (2005). TRNSYS 16 Volume 9 - Weather Data. Wisconsin, Madison, U.S.A.

Solar Energy Laboratory of University of Wisconsin. (2005). TRNSYS 16 Volume-9 Weather Data. Wisconsin, Madison, U.S.A.

Spirkel, W. (1998). DF-Dynamic Systems Testing 2.8. Germering, Germany: In-situ scientific software.

SQL server. (2008). Microsoft Corporation. Retrieved March 01, 2013, from www.microsoft.com: http://msdn.microsoft.com/en-us/library/ms 143432.aspx

SQL Server. (2008). Microsoft Corporation. Retrieved April 03, 2010, from www.microsoft.com: http://msdn.microsoft.com/en-us/library/ms143432.aspx

SRCC Document. (1994). Methodology for Determining the Thermal Performance Rating for Solar Collectors. Florida: Solar Rating \& Certification Corporation (SRCC).

Srikhririn, P., Aphornratana, S., \& Chungpaibulpatana, S. (2001). A Review of Absorption Refrigeration Technologies. Renewable and Sustainable Energy Review , 5, 343-72.

Statistics Canada. (2011). Energy Statistics Hanbook, 2nd Quarter 2011. Statistics Canada. 
Stephan K. (1982). Absorption Heat Pumps and working Pair Developments in Europe Until 1974. Berlin, Germany: Proceedings of Workshop on New Working Pairs for Absorption Process.

Stevenson, D. (1983). Residential Hot Water Use Patterns (Volume I). Report for the Canadian Electrical Association Research and Development, Montreal, QC.

Stocker, W., \& Jones, J. (March 1, 1983). Refrigeration and Air-conditioning. (s. edition, Ed.) McGraw-Hill publishing Company.

Stover, D. (1994, March 1). Canada's Advanced Houses. Popular Science , pp. 73-78.

Swinton, M., Moussa, H., \& Marchand, R. (2001). Commissioning Twin Houses for Assessing the Performance of Energy Conserving Technologies. Florida: Proceedings for Performance of Exterior Envelopes of Whole Buildings VIII: Integration of Building Envelopes.

Tacchi, V. (2003). Patent No. 6648236. United States.

Tanaka, M., Girard, G., Davis, R., Peuto, A., \& Bignell, N. (2001). Recommended table for the density of water between $0 \circ \mathrm{C}$ and $40 \circ \mathrm{C}$ based on recent experimental reports. Metrologia, Volume 38, 301-309.

Tanha, K. (2011). Evaluating the Performance of Two Solar Domestic Hot Water Systems of the Archetype Sustainable House. Ryerson University, Mechanical Engg. Ryerson University.

Taylor, D., \& Crossman, G. (1996). Virginia Power Water Heater Testing and Optimization Project. Final Report for Virginia Power, Old Dominion University, Norfolk, Virginia.

Taylor, M., \& Krane, R. (1991). Second Law Optimization of Sensible Heat Thermal Energy Storage System with a Distributed Storage Element-Part-1: development of the Analytical Model. Journal of Energy Ressources Technology, 113, 20-26.

The California Public Utilities Commission (CPUC). (2009). California Solar Initiative Program Handbook. California: California Solar Initiative.

The Engineering ToolBox. (2005). Retrieved December 2008, from Propylene Glycol based Heat-Transfer Fluids: http://www.engineeringtoolbox.com/propylene-glycol-d_363.html

The U.S. Department of Energy (DOE). (2001). Energy Conservation Program for Consumer Products: Energy Conservation Standards for Water Heaters: Final Rule. Federal Register, Rules and Regulations, Vol. 66 (11), pp. 4474 - 4497.

The U.S. Department of Energy (DOE). (2000). Technical Support Document: Energy Efficiency Standards for Consumer Products: Residential Water Heaters, Including: Regulatory Impact Analysis",. Retrieved April 2011, from http://www1.eere.energy.gov

Thermal \& Mechanical Equipment Company (TMEC). (2012). Engineering and Operation Guide.

Retrieved 03 01, 2013, from www.tmec.com:

http://www.tmec.com/attachments/contentmanagers/331/93.pdf 
Thomsen, K., Wittchen, K. B., \& EuroACE. (2008). European national strategies to move towards very low energy buildings. Hørsholm: Danish Building Research Institute, Aalborg University.

TRCA, BILD. (2009). About: Mission. Retrieved October 2009, from Toronto and Region Conservation Authority: http://www.sustainablehouse.ca/about/mission.dot

Trinkl, C., Zörner, W., Alt, C., \& Stadler, C. (2005). Performance of Vacuum Tube and Flat Plate Collectors Concerning Domestic Hot Water Preparation and Room Heating. 2nd European Solar Thermal Energy Conference. Freiburg.

Union Gas. (2013). Chamical Composition of Natural Gas. Retrieved 03 03, 2013, from Union Gas: http://www.uniongas.com/aboutus/aboutng/composition.asp

Van Decker, G. (2008, February). Analysis of Drain Water Heat Recovery Applications in Northern Minnesota Based on Demographic Characteristics, Supply Water Temperature, and Two Studies by Natural Resources Canada. Retrieved December 2010, from Renewability: http://www.renewability.com/uploads/documents/en/analysis_dwhr_minnesota.pdf

Vasiliev, L., Mishkinis, D., \& Vasiliev Jr., L. (1996). Multi-effect Complex/Compound Ammonia Sorption Machines. International Absorption Heat-pump Conference, (pp. 3-8).

Viessmann Ltd. (2010b). Vitosol Solar Heating Systems. Retrieved May 4, 2011, from www.viessmann.com.

Viessmann Ltd. (2010). Vitotech technical guide. Retrieved April 12, 2011, from www.viessmann.com. Vitotech technical guide. (2010). Viessmann Limited. Retrieved April 8, 2010, from www.viessmann.com: http://www.scribd.com/doc/19338747/Viessmann-Vitosol-Thermal-Solar-Collectors-System-DesignGuidelines

Vogel R. (1986). Possible Adsorprion pair for Solar cooling. Ambient Energy , 7 (4), 1983-90.

Vollrad Kuhn, J. K. (2008). MicroCHP: Overview of selected technologies, products and field test results. Applied Thermal Engineering , 2039-2048.

Walker, A., Mahjouri, F., \& Stiteler, R. (2004). Evacuated-Tube Heat-Pipe Solar Collectors Applied to the Recirculation Loop in a Federal Building. Solar 2004 Conference. Portlan, Oregan USA.

Walker, I., \& Sherman, M. H. (2007). Humidity Implications for Meeting Residential Ventilation Requirements. California: Ernest Orlando Lawrence Berkeley National Laboratory.

Wang, D., Li, W., Li, D., \& Xia, Y. (2010). A Review on Adsorption Refrigeration Technology and Adsorption Deterioration in Physical Adsorption systems. Renewable and Sustainable Energy Reviews, 14, 344-353.

Wang, D., Wu, J., \& Wanr, R. (2005). Research on Novel adsorption Chiller Driven by Low Grade Heat Source. International Sorption Heat pump Conference. Denver, USA. 
Weiss, W., \& Rommel, M. (2008). Process Heat Collectors; State of the Art within Task 33. Gleisdorf, Austria: AEE INTEC.

Whispergen User Manual. (2007, June). Christchurch, New Zealand: Whispergen.

Whispergen. (2007, June). Whispergen User Manual. Christchurch, New Zealand: Whispergen.

Wiehagen, J., \& Sikora, J. (2003). Performance Comparison of Residential Hot Water Systems. Upper Marlboro, Maryland: NAHB Research Centre.

Wong, L., Mui, K., \& Guan, Y. (2010). Shower Water Heat Recovery in high-rise residential buildings of Hong Kong. Applied Energy, 87, 703-709.

Wu, D., \& Wang, R. (2006). Combined Heating, Cooling and Power: A Review. Energy and Combustion Science, 32, 459-495.

Zaloum, C., Lafrance, M., \& Gusdorf, J. (2007). Drain Water Heat Recovery Characterization and Modeling. Ottawa: Sustainable Buildings and Communities, Natural Resources Canada.

Zambolin, E., \& Del Col, D. (2010). Experimental Analysis of Thermal Performance of Flat Plate and Evacuated Tube Solar Collectors in Stationary Standard and Daily Conditions. Journal of Solar Energy, 84, 1382-1396.

Zhang, D., Barua, R., \& and Fung, A. (2010). Development of Monitoring System for the Sustainable Archetype House at Kortright Centre. 1st International High Performance Buildings Conference at Purdue University (pp. 3482 (1-8)). Indiana: Compressor/Refrigeration \& Air Conditioning/High Performance Buildings Conferences at Purdue.

Zhang, D., Barua, R., \& Fung, A. (2011). TRCA-BILD Archetype Sustainable House - Overview of Monitoring System and Preliminary Results for Mechanical Systems. ASHRAE Transactions, Vol. 117, Part 2, 597-612. 